HYDRAULIC RESEARCH

\title{
in the \\ UNITED STATES
}

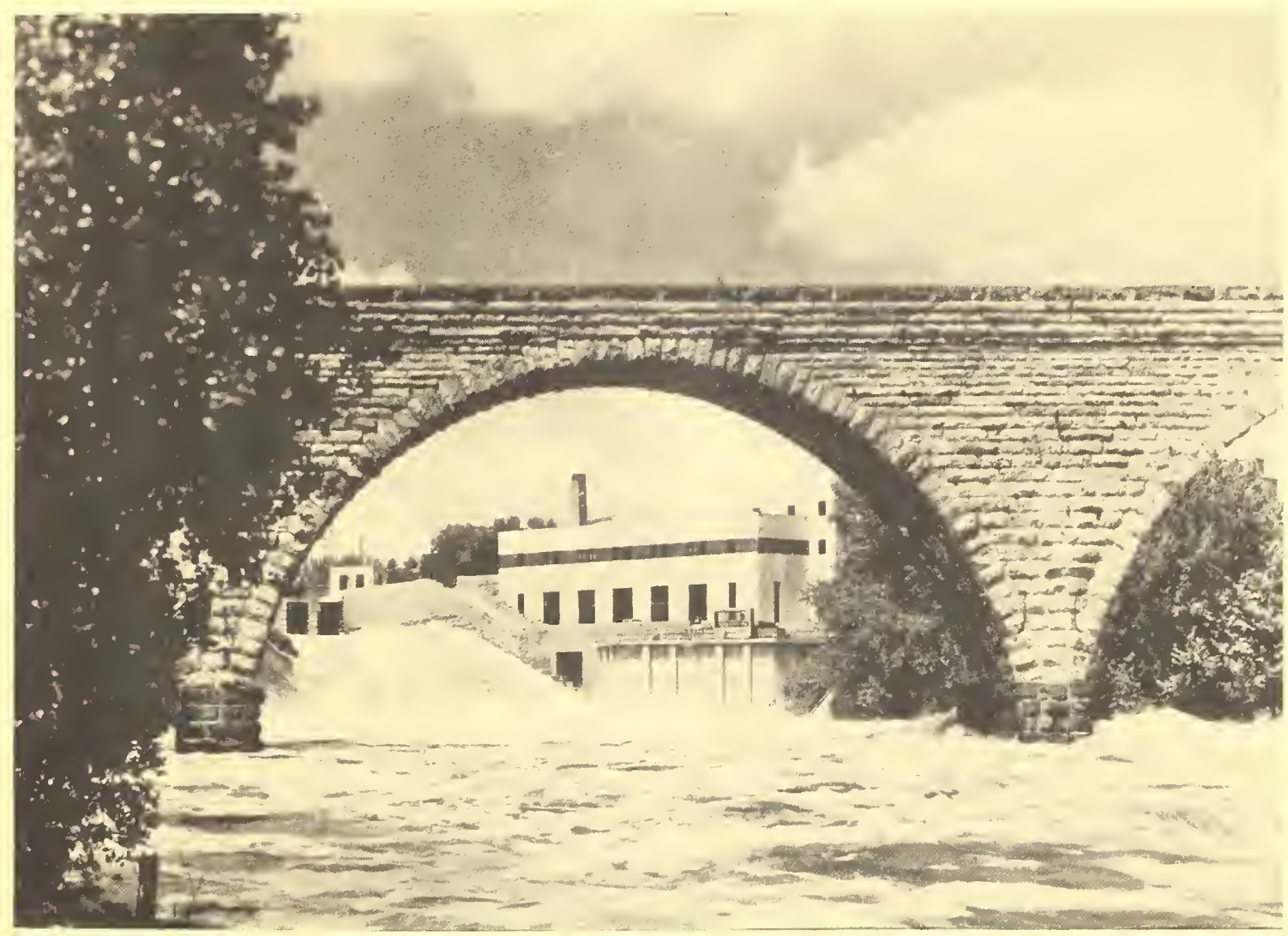

St. Anthony Falls Hydraulic Laboratory, University of Minnesota

\section{U. S. DEPARTMENT OF COMMERCE NATIONAL BUREAU OF STANDARDS \\ WASHINGTON, D. C.}


' 
U. S. DEPARTMENT OF COMMERCE W. Averell Harriman, Secretary
NATIONAI, BUREAU OF STANDARDS E. U. Condon, Director

National Hydraulic Laboratory

of the

National Bureau of Standards

\section{HYDRAULIC RESEARCH IN THE UNITED STATES}

Edited by Florence L. Bain

Volume XI

April 1947

\section{CONTENTS}

Foreword . . . . . . . . 4 Translations....... . . 142

Key to projects . . . . . . 4 Comm1ttees . . . . . . . . 145

Current projects........ 5 Laboratory notes . . . . . . 147

Completed projects....... 95 subject 1ndex of projects . . 155

\section{HYDRAULIC LABORATORIES}

Alaska, Unlversity of . . . . . . . . . . . . . . . . . . 152

Arkansas, Unlversity of . . . . . . . . . . . . . . . . . . 147

Armour Regearch Foundation . . . . . . . . . . . . . . . . 5

BaldwIn Locomot1ve Works . . . . . . . . . . . . . . . . . . 5

Bonnev1lle Hydrquilc Laboratory . . . . . . . . . . . 64, 130, 152

Brooklyn, Polytechnic Inst1tute of . . . . . . . . . . . . . . . 147

Bucknell Un1vers1ty . . . . . . . . . . . . . . . . . . 6 6

Byron Jackson Compsny . . . . . . . . . . . . . . . . . . 147

Callfornia Institute of Technology . . . . . . . . . . . . . 6, 95

Californ1a, Un1versity of

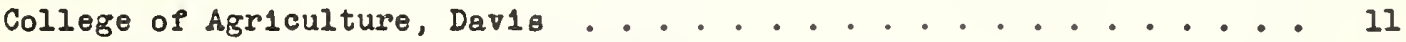

College of Agricuiture, Los Angeles . . . . . . . . . . . . . 14

C lege of Eng1neer1ng, Berkeley . . . . . . . . . . . . 15, 96

College of Englneering, Los Angeles . . . . . . . . . . . . 20, 147

Cal1forn1a, University of Southern . . . . . . . . . . . . . . 20

Carnegle Inst1tute of Technology . . . . . . . . . . . . . . 21, 98

Catholic Univereity of America . . . . . . . . . . . . . . . 147

Clemson Agricultural College . . . . . . . . . . . . . . . . 148

Colorado A \& M College . . . . . . . . . . . . . . 21, 99, 148

Colorado, Unlveralty of . . . . . . . . . . . . . . . . . . 23 
Columbla Un1versity

Department of C1vil Englneering . . . . . . . . . . . . . 24

Department of Mechanlcal Englneering . . . . . . . . . . . . 148

Cornell Unlverelty . . . . . . . . . . . . . . . . . . . . . 99

Dertmouth Colloge . . . . . . . . . . . . . . . . . . 152

Florlda, Un1versity of . . . . . . . . . . . . . . . . . . . 148

George Washington Unlversity . . . . . . . . . . . . . . . . . . 152

Ideho, UnIversity of . . . . . . . . . . . . . . . . 25, 148

IIIno1s, University of . . . . . . . . . . . . . . . 26, 100

Iowa Inst1 tute of Hydraul1c Researoh . . . . . . . . . . . . . . 26, 100

Iowa, Stete University of . . . . . . . . . . . . . . . . 26, 100

Lafayette College . . . . . . . . . . . . . . . . . . . . 152

Leffel \& Company, The James . . . . . . . . . . . . . . . . 148

Lehlgh Un1vers1ty . . . . . . . . . . . . . . . . . . 32, 103

Loulalana State University and A \& College . . . . . . . . . . 104, 148

Malne, Unlversity of . . . . . . . . . . . . . . . . . . 148

Massachusetts Inst1tute of Technology

Department of C1vil and Sandtary Englneering . . . . . . . . . 148

Department of Mechanical Englneering . . . . . . . . . . . . 33

Michlgan, Unlversity of . . . . . . . . . . . . . . . 34, 149

Minnesota, University of . . . . . . . . . . . . . . . . 35, 104

Missourl, Unfversity of . . . . . . . . . . . . . . . . . 39

Nat1onal Hydral1c LeVoratory . . . . . . . . . . . . 53, 116, 152

New Jersey, state of . . . . . . . . . . . . . . . . . . . 149

Newport News Shlpbullaing and Dry Dock Company . . . . . . . . . . 39, 105

New York Unlversity . . . . . . . . . . . . . . . . . . . 152

North Carolina, Un1versity of . . . . . . . . . . . . . . . . 41

Northwestern Un1versity . . . . . . . . . . . . . . . . 41, 149

Oh10 state UnIversity ...... . . . . . . . . . . . . 42, 107

Oklahoma A \& K College . . . . . . . . . . . . . . . . . . . 152

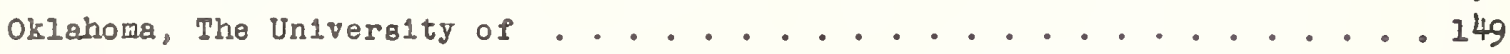

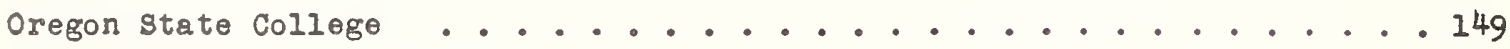

Pelton Water Wheel Company . . . . . . . . . . . . . . . . . 149

Penngylvanla state College . . . . . . . . . . . . . . . . . . 4 42

Penngylvania, Unlversity of . . . . . . . . . . . . . . . . . . . . 44

Penngylvania Water \& Power Company . . . . . . . . . . . . . . 44, 108

Princeton UnIversity ... . . . . . . . . . . . . . . . . . 46

Purdue Un1versity . . . . . . . . . . . . . . . . . . . . . 108

Rennseleer Polytechnic Inst1tute . . . . . . . . . . . . . . . . . 150

Research Foundation for Crosb-Connection Control .............. 20

Roohester, Undversity of . . . . . . . . . . . . . . . . . . . 152

Rocky Mountaln Hydraulic Laboratory . . . . . . . . . . . . . . . 150

St. Anthony Fallo Hydraulic Laboratory . . . . . . . . . . . . 35, 52, 104

S. Morgan Smlth Company . . . . . . . . . . . . . . . . 46, 109

Southern Methodist Un1verbity . . . . . . . . . . . . . . . . 48

Stanford Un1vers1ty . . . . . . . . . . . . . . . . . . . . 110

Stevens Inst1tute of Technology . . . . . . . . . . . . . . 49, 150 
Syracuse University ... . . . . . . . . . . . . . . . . 151

Taylor Model Basin . . . . . . . . . . . . . . . . . . . 58, 127

Tennesser, The Un1versity of . . . . . . . . . . . . . . . . 151

Texas A \& $\mathrm{M}$ College . . . . . . . . . . . . . . . . . . . 151

Union College . . . . . . . . . . . . . . . . . . . . . 152

U. S. Waterways Experiment station ............. . 68, 132, 142

Utah State Agrloultural College . . . . . . . . . . . . . . . . 49

Washington, The state College of .................. . 151

Washlngton, Unlversity of . . . . . . . . . . . . . . . . . . 111

Wayne Univerglty . . . . . . . . . . . . . . . . . . . 151

W18cons1n, Un1versity of . . . . . . . . . . . . . . . 49, ill

Worcester Polytechn10 Inst1tute . . . . . . . . . . . . . . . 115

Yele Un1vere1ty . . . . . . . . . . . . . . . . . . 152

\section{U. 8. GOVERNMENT LABORATORIES}

Department of Agrioulture

Forest service, California Forest \& Range Experiment station . . 90, 116

Soll Conservation Service, Coghocton, Oh10............ 50

Soll Conervation Servioe, D171810n of Drainage and Water Control .. . 252

Soll Coneervation Service, Logan, Utah .............. 52

So1l Conservation Service, Minneapol1в, M1nn. ........... 52

Soll Conservation Service, Stlllwater, Okla. . . . . . . . . . 52

Department of Commerce

National Bureau of standarda . . . ........ . 53, 116, 152

Natlonal Hydraul10 Laboratory ............ . 53, 116, 152

Weather Bureau . . . . . . . . . . . . . . . . 56

Department of the Interior

Goologlcal survey . . . . . . . . . . . . . . . . . 57

Bureau of Reclamation, Denver, Col. .........57, 118, 142, 152

Bureau of Reclamation, El Paso, Tex................ 127

Navg Department

Dav1d Taylor Model Basin . . . . . . . . . . . . 58, 127

U. S. Naval Englneer1ng Exper1ment station ............ 61

Paneme Canal Hydraulic Laboratory . . . . . . . . . . . . . . 61, 127 Tennesger Valley Authorlty . . . . . . . . . . . . . . . . 152

War Department, Corps os Engineers,

Beach Erosion Board . . . . . . . . . . . . . . . 61

Log Angeleg District . . . . . . . . . . . . . . . 63, 130

Portland Dibtrlot ................. 64, 130, 152

8t. Paul Distriot . . . . . . . . . . . . 65, 131, 142

U. 8. Wetemays Experiment station........... 68, 132, 142

\section{FOREIGN LABORATORIES}

European and As1at1o laboratorles . . . . . . . . . . . 153

Mol11l inivars1ty . . . . . . . . . . . . . . . . 153

Montreal, Eoole Polytechn1que de .............. 94, 141

Shawinigan Water and Power Company . . . . . . . . . . . . 153

Toronto, UnIversity of ....................... 95 
Th1s bullet1n, Volume XI, Hydraul1c Researoh in the United States, is the lirst edition to be published since 1942, when Volume X appeared. The first volume was 18 sued by the National Bureau of Standarde in 1933, and cther volumes annually thereafter unt1l 1942, when publication was discontinued because of the war. It 18 expeoted that in the future $1 t$ wlll be 1 soued annually.

As heretofore, the inforbition contained in this bulletin is complled with the cooperation of the varlous hydraulic and hydrologio laboratories in tho Un1ted States. It contains, so far as 1t has been possible to collect 1t, a summary of researoh now in progrese in these laboratories, as well as researoh which has been completed since the last bulletin was 1ssued.

Because of the lapse of time ince the last $1 \mathrm{gaue}$ and the great amount of material recelved for this odtion, it has soemed desirable to olasalfy information somewhat differently than previously. The first seotion of the bulletin 1s devoted, as usual, to reports on current projeote. Following that, the section dealing w1th abstracts of completed projects and references to publicotlons has been enlareed and now 1ncludes full reports, where avallable, of projects which have been completed during the past flve years. A ner section, Laboratory Notes, has been added, in order to present up-to-date information about laboratory activitiea.

A new numbering oystem has been started, and in this edition the new projeot number is given flrst, followed by the project number formerly assigned in the case of old projects. Th1s old number will be äropped in aubrequent 1 seues and only the new number 111 appear. In the section devoted to reports on oompleted projects, no new numbers have been asslgned, but the old number, when one has previousiy been assigned, is given for purposes of ldentification.

It is emphasized again that the National Bureau of Standards does not bave in 1ts plles reporta or detalled information regarding the research projects reported by other organizationa. Such information may be obtalned from the correspondent l1sted under (d) or 1mmediately following the title of the organizat1on。

Coples of thle bulletin are supplied to interestea persons and organizations without oharge and may be obtained by writing to the Chlef, Nat1onal Hydraulio Laboratory, National Bureau of standards, Waghington 25, D. C. A ma1ling 11 . 1s malntained whlch includes the names of persons who have requested this service in writing. Beoause of the disuption of laboratory work generally during the war, the ma1ling list needs complete revision, and changes, corrections, and additions are solic1ted.

The supply of earlier bulletine 1 s exhausted and there are no more coples for general alstribution. A few coples are avallable to libraries only.

(a) Titlo of project.

(b) Project conducted for.

(c) Investigators. (d) Correspondent.

(e) Nature of project.

(1) Purpose. (g) Scope and method.

(i) Present atatus.

(1) Remarks. 
ARMOUR RESEARCH FOUNDATION, Ill1no18 Ingt1tute of Technology, Ch1oago 16, Ill.

(1) FLUID FLOW AND HEAT TRANSFER IN ARTIFICIALLY ROUGHENED PIPEB.

(b) Research Corporation, Man1towoc shipbullding Corporation, Armour Researoh Foundation, and Illinols Institute of Technology.

(c) V. L. Streeter, R. G. Owens, R. A. Budenbolzer, O. E. Te1chmann.

(d) Prof. V. L. Streeter, 35 West 33rd street, Chloago 16, Ill.

(e) Experimental for generel information.

(f) To conf1rm the Prandt-von Kdrman veloo1ty distribution and resistance laws in geometrically roughened pipes, and to obtain heat transfer data.

(g) Three geometrically slmilar roughnesses are maohined into 4.5-1noh aluminum tub1ng. Velocity distributions, pressure drops, and turbulenoe measurements are to be taken.

(b) Plpes now belng roughened, instruments under construction.

(1) Progress reports issued quarterly.

THE BALDWIN LOCOMOTIVE WORKS, I. P. Morr1s Department, Eddystone, Pa.

(2) EFFICIENCY, HORSEPOWER AND CAVITATION TESTS - ADJUSTABLE BLADE, PROPELLER TYPE TURBINE MODELS.

(b) The Baldwin Locomotive Works, I. P. Morris Department.

(c) R. B. W1111, Superv1 sing Eng1neer; H. J. Dav1s, superv1sor of Hydraul10 Leboretory.

(d) H. J. Dar1s, Supervisor of Hydraulic Laboratory, I. P. Morris Dept., The Baldwin Locomotive Works, Eddjatone, Pa.

(e) Bxperimental research in connection with future design of product.

(1) To improve upon turbine performance.

(g) Runners of various designs in combination with diferent turbine settings are belng tested in a olosed Ilume, the bydraul10 gradient of whlch may be ralsed or lowered to slmulate the operating conditions of a commerolal prototype.

(h) Tosts are in progress.

(3) EFTICIENCY, HORSEPOWER AND CAVITATION TESTS - FRANCIS TYPE TURBINE MODELS.

(b) The Baldw1n Looomot1ve Works, I. P. Morris Department.

(c) R. B. W1111, Superv181ng Eng1neer; H. J. Dav1s, Suporv180r of Hydraul10 Laboretory.

(d) H. J. Dav1s, Supervisor of Hydraul10 Laboratory, I. P. Morr1s Dept., The Baldwin Locomotive Works, Eddystone, Pa.

(e) Experimental research in connection w1th future design of product.

(1) To provide a complete set of model runners of modern design with a record of thelr performance covering the applicable range of spec1f1c speeds for Frencle type turbines.

(g) Franc1s type turbines of different spec1fic speeds are being tested in a olosea flume, the hydraul1c gradient of whloh may be ralsed or lowered to simulace the operating conditions of a commerelal prototype.

(h) Teste are in progress. 
BUCKNELL UNIVERSITY, LEW1 Bburg, Pa.

(4) DEVELOPMENT OF SURFACE WAVES BY WIND.

(b) Laboratory project.

(c) D. M. Griffith, Harold Flinsoh.

(d) Dr. Harold Flinsoh, Dopt. of C1v1l Englneering, Bucknell University, Lew1 sburg, Pa.

(e) General theoretical and experimental research.

(1) To develop a theory of the growth of surface waves under the action of wind, and to compare this theory with the results of measurements.

(g) Research leading to papers on the theorles of surface wave growth, measurements in laboratory and in nature, and on the comparative results of theory and measurement.

(h) A paper on the proposed theoretical approach is in preparation, and exper1mental equipment 18 being assembled.

(1) "An experimental invest1gation of windagenerated surface waves." Harold v. N. Flinson. Ph. D. thes1s, Un1versity of Minnesota. May 1946.

(5) SHIP STABILITY AND ROLLING PERIOD.

(b) Laboratory project.

(o) D. M. Griffith, Harold Flinsch.

(d) Dr. Harola Flnsch, Dept. of C1v1l Englneering, Bucknell Univers1ty, Lew1sburg, Pa.

(e) General theoret1cal and experimental research.

(f) To develop general formulas for the measure of btablitty and the rolling period of ships.

(g) Exact and approximate formulas determining cortain characteristics of ships, such as rolling period, metacentrio helght, etc., are compared with the results of experiments on ship models.

(h) Preliminary experiments have been performed on a basic model, and some of the results assembled in a brief report.

CALIFORNIA INSTITUTE OF TECHNOLOGY, Pasadena, Cal11.

Inquiries concerning projects No. 6 to 11, incl, should be addressed to Pro?. Robert T. Knapp or Dr. V1to A. Vanon1, Californ1a Inst1tute of Technology, Pasadena, Cal11.

(6) (659) MECHANICS OF SUSPENDED LOAD TRANSPORTATION.

(b) Research DIv1sion, Bo11 Conservation Service, U. S. Dept. of Agrioulture.

(c) V. A. Vanon1, J. T. Rostron.

(e) Basic experimental research.

(f) To investigate the internal mechanios of transportation of suspended load in flowing water; the effects of the material in suspension upon the veloc1ty distribution of the flow; the distribution of sediment in open channel Ilov.

(h) The study 18 being continued.

(1) For deta1ls of experiments and results, see "Transportation of suspended sediment by water." V1to A. Vanon1. Trans. A.S.C.E., Vol. III: 67-133. 1946.

(7) TRANSPORTATION OF BED MATERIAL LOAD.

(b) Research D1v1sion, So1l Conservation Service, U. S. Dept. of Agriculture.

(c) H. A. Elnstein. 
(e) Basio experimental research.

(f) To determine a general relationship between the rate of sediment movement by a stream and the hydraulic factors.

(g) Present experiments are belng carried out in a closed oircuit flume, 10 inches wide and 40 feet long. The procedure used follows, in a general way, that used in conventional bed load experiments, except that efforts are belng concentrated on studying the relatively high rates of transportation where an appreciable amount of the materlal moves in suspension.

(h) The work is proceeding actively.

(1) This research may be considered an extension of the investigator's previous work on sediment movement which 18 outlined brleply in the following publicat1ons:

"Formulas for the transportation of bed load." H. A. Elnstein. Trans. A.S.C.E. Vol. 107: 561-597. 1942.

"Bed losd transportation in Mountain Creek." H. A. Elnstein. U. S. Dept. of Agrioulture, So1l Conservation Servioe, mimeograph publication, TP55. August 1944.

\section{(8) (810) DENSITY CURRENTS.}

(b) Research Division, Soll Conservation Service, U. B. Dept. of Agriculture.

(c) H. S. Bell, R. T. Knapp.

(e) Basio experimental researoh.

(1) To investigate density currents resulting from suspensions of fine sediments in reservo1rs and to establish principles governing thelr behavior.

(h) A continuing projeot.

(1) For detalls of experiments and recent results, see the following publications: "Density currents: Their mixing characteristics and their effect on the turbulence structure of the asscclated flow." Robert T. Knapp. Proc. Second Hydraulics Conf., Bul. 27, Un1v. of Iowa Studies in Engineering: 289-306. 1943.

"Density currents as agentg for transporting pine sediments." Hugh Stevens Bell. Journal of Geology, Vol. L, No. 5: 512-547. 1942.

"Some evidence regarding the kind and quantity of sediment transported by density currents." Hugh Stevens Bell. Trans. American Geophysical Union, Pt. 1: 67-73. August 1942.

"Stratifled flow in reservolrs and 1 ts use in prevention of silting." Hugh Stevens Bell. U. S. Dept. of Agriculture, M180. Pub. No. 491. September 1942.

"Sedimentation in reservo1rs." Hugh Stevens Bell. (D1scussion of the paper by Berard J. W1tz1g.) Proc. A.S.C.E., Vol. 69: 1630-32. December 1943.

"Future of Lake Mead and Elephant Butte Reservo1r." Hugh Stevens Bell. (D1scussion of the paper of J.C. Stevens.) Proc. A.S.C.E., Vol. 72, No. I: 83-93. January 1946.

(9) (\$12) HYDRAULIC DESIGN OF EROSION CONTROL STRUCTURES BY MEANS OF MODEL TESTS.

(b) Research Division, Soll Conservation Service, U. S. Dept. of Agriculture.

(c) V. A. Vanoni, H. A. Einstein, J. T. Rostron.

(e) Experimental studies to obtain design information.

(P) To obtain design information for typical and speol110 structures.

(g) Th1s project includes a number of investigations conducted by the Laboratory on Hydraul1c Structures. Some of these are for particular structures and lead to findings and recommendations of interest only to one structure. other tests cover more general investigation leading to results of more widespread interest. The procedures followed are those normally used in the hydraulic model laboratory.

(h) The project is being continued on a part-time basis. 
(1) The following reports cover work under this project:

"Hyaraulic deslgn of durable structures for gulley control." Brooks T. Morrls and D. C. Johnson. Trans. A.S.C.E., Vol. 108: 887-890. 1943. "Scour control and scour resistant design for hydraulic structures." Brooks T. Morr18. Trans. American Geophysical Union, Pt. I: 60-67. 1942.

(10) (1101) STABILITY OF NATURAL SEDIMENTS UNDER LOCALLY CONCENTRATED ATTACK ON FLOWING WATER.

(b) Research D1vision, Soll Conservation Service, U. S. Dept. of Agriculture.

(c) H. A. Elnstein, V. A. Vanoni.

(e) Basic experimental research.

(f) To establish a rational basis for predicting the rate of scour of sediments and pavements at the foot of drop structures, overfall dams, and at other places where several erosion forces are active.

(g) The work has included both laboratory studies and pleld studies, and it is contemplated that future studies w1ll continue along both of these lines. The laboratory studies included measurements of erosion due to jets, as well as in model stlling basins of varlous designs using the normal laboratory technique.

(h) Thls project 18 temporarily 1nactive, due to lack of 8 taff.

(11) PIPE AND WIRE REVETMENT FOR STREAM CONTROL.

(b) Flood Control Survey division, Soll Conservation Service, U. S. Dept. of Agriculture.

(c) J. T. O'Brien, H. A. Einstein, V. A. Vanoni.

(e) Field and laboratory investigation.

(f) To obtain information upon wilch to base imorovements on the design of pipe and wire revetments for streams.

(g) The study will include fleld observations and investigations as well as laboratory experiments. The pleld studies will be conducted by observing existing installations of pipe and wire revetment in the intermittent streams of Southern California and the Southwest with a view to determining the action and the effect of the various components of a revetment system. Thls study w1ll be alded by an analysis of whatever practical data on flows, Pallures, etc., may be avallable in the plles of the agenoles responsible for the instaliations. The laboratory program will be designed to determine the general behavior of this type of revetment and to evaluate any modifloatlons whlch are suggested by the field study. Laboratory flumes are avallable for this study in which plows carrying high concentrations of sediment can be circulated.

(h) The fleld investigation is well under way.

(12) INVESTIGATION OF WAVES AND SURGES IN THE APRA HARBOR, GUAM, MI.

(b) Bureau of Yards and Dooks, U. S. Navy.

(c) R. T. Knapp, W. O. Wagner, M. Me1sels.

(d) Prof. Robert T. Knapp, W. O. Wagner, California Inst1tute of Technology, Pasadena, Cal11.

(e) Experimental project to obtain design information.

(1) To obtain information on the wave and current action in Apra Harbor that will serve to gulde the development of the Harbor by the U. S. Navy.

(g) Two models of the Harbor have been built. A small model on the scale of 1:960 was bullt in an outdoor laboratory on the campus. A model with a scale of 1:360 has been bullt in a larger basin at Azusa, Cal1f. Tho larger basin is housed in an alrplane hangar 140 feet by 160 peet. Both model basins are equipped with wave and surge machines to reproduoe cond1tions observed in the fleld. Wave holghts in the model are measured with special eleotric depth gauges which record on an oscillograph, thus enabling wave amplitude surveys to be made of the entire model in a relatively short time. 
(b) The work is proceeding actively.

(1) The work 1 s simllar in nature to an 1nvest1gation made by the Inst1tute, during the war, of the Naval Harbor at Terminal Island. Many of the techniques being used now were developed in this study, which $1 \mathrm{~s}$ covered In a report by Prof. Robert T. Knapp and Dr. V1to A. Vanons ent1tled Wave and surge studies for the Navy Base", Term1nal Island, Cal1fornia, January 1945.

(13) (821) STUDY OF PRE-ROTATION AND REVERSE FLOW AT THE EYE OF A CENTRIFUGAL PUMP.

(b) Laboratory project.

(c) R. T. Knapp, R. L. Daugherty.

(d) Prof. Robert T. Knapp, Prof. R. L. Daugherty, Cal1 fornia Inst1tute of Technology, Pasadena, Cal1f.

(e) Experimental project for student thesis.

(f) Experimental verlfloation of the flow characteristics within a centrifugal pump, especially in the region near the impeller eye.

(b) The first serles of Investigations has been completed.

(1) The results are included in a report on the Bureau of Reclamation Research Program.

(14) GRAND COULEE PUMP MODEI TESTS.

(b) Byron Jackson Company.

(c) R. T. Knapp, R. L. Daugherty, A. Hollander, E. Lindros.

(d) Prof. Robert T. Knapp, Cal1fornia Inst1tute of Technology, Pasadena, Cal1f.

(e) Experimental progrem to obtain design information.

(1) To determine the best pump unit for the spec1fled varying conditions.

(g) A number of 1mpellers and diffusers were tested to show the effect of minlmum changes in design upon the sizes of the unit for a minimum specipled efflclency, and on the change of maximum efflclency by these varlations. The principal changes in design were in the impeller and diffuser angles.

(b) The program is proceeding actively.

(1) Reports are to be subm1tted after acceptance tests by the Bureau of Reolamation. These are expected to cover the performance of the final unit only.

(15) STUDIES OF CAVITATION PHENOMENA.

(b) Bureau of Ordnance, U. S. Navy.

(c) R. T. Inapp, A. Hollander.

(d) Prof. Robert T. Knapp, D1rector, Hydrodynam1cs Laboratory, Cal1fornia Institute of Technology, Pasadena, Cal1f.

(e) Basic experimental research.

(P) To 1nvestigate the bas1c nature of cav1tation phenomena.

(g) Visual and photographic observations are made of cav1tation on bodies of revolution and on other shapes, w1th a view to obtalning a physical plcture of the oavitation phenomena. With this information, the problem will then be attacked analytically. For this work, a water tunnel w1th a worising section of 14 inchas in diameter and with a maximum velocity of 70 fps 18 avallable. Motion pictures have been taken at rates as high as 20,000 per second and equipment $1 \mathrm{~s}$ belng developed for materlally 1ncreasing this rate. A new tunnel $1 \mathrm{~s}$ also beling constructed wh1ch will have the same s1ze working section, but a maximum speed of $100 \mathrm{fps}$. The new tunnel w1ll be unique in that provision $1 \mathrm{~s}$ made to absorb air bubbles that are coming out of solution during cavitation before they are circulated so that the flow entering the working section will always be free from alr. The tunnel will also make 1t possible to control the a1r content and to study 1 ts effect on cav1tation.

(h) The project 18 progressing actively. 


\section{(16) HYDRODYNAMIC FORCES ON SUBMERGED BODIES.}

(b) Bureau of Ordnance, U. S. Navy.

(c) R. T. Knapp, J. Levy, G. B. Robleon, R. A. Howard, J. P. O'Ne1ll, J. Kaye.

(d) Prof. Robert T. Rnapp, Director, Hydrodynamica Laboratory, California Institute of Technology, Pasadena, Cal1f.

(e) Basic laboratory research.

(i) To develop basic concepts and information that will permit the prediction of the dynamic bebavior of bodles moving in a lluia.

(g) Forces on bodles of different shapes and designs are measured in water tunnels and the 1mportant steady state and damping force coefflclents are thus obtalned. These results are then used to predict the dynamic behavior through analys18. Once this 18 done, a body can be designed to have the desired dynamic behavior by selecting a abape with the appropriate values of these coefflcients. Three major pleces of apparatus are avallable for thls type of study. The first is a 14 -inch diameter high speed water tunnel with a maximum velocity of $70 \mathrm{fps}$, and the second $1 \mathrm{~s}$ a Iree surface water tunnel with a working section of 20 inches by 20 inches in cross section and with a maximum velocity of about 30 fps. Th1s apparatus is particularly suftable for determining the effect of a free surface on the dynamic forces on a submerged body. Both of these tunnels also have controlled pressure which make 1 possible to study cavitation and 1 ts effect on forces. The third apparatus is a launching tank where bodles can be launched Prom the air into the water at hlgh apeeds and the pathe in the alr and in the water observed photographlcally. The pressure of the alr over the water can be controlled and 1 ts elfect on the behavior of bodles during vater entry studied.

(h) The project 1 s proceeding actively.

(17) THE ANALOGY BETWEEN SURFACE SHOCR WAVES ON LIQUIDS AND SHOCKS IN COMPRESSIBLE GASES.

(b) Bureau of Ordnance, U. S. Navy.

(c) R. T. Knapp, H. A. Elnstein, E. G. Ba1rd.

(d) Prof. Robert T. Knapp, Dlrector, Hydrodynamics Laboratory, Callfornia Institute of Technology, Pasadena, Callf.

(e) Basic experimental rosearch.

(f) To Investigate the applicab1lity of the water analogy to the study of shocks in gases and to develop techniques for moking measurements of surface shock waves on 1lquids.

(g) A specially bullt ripple tank about 4 feet wide and 6 feet long 18 used in these studies. Waves of different shape and intensity are produced in this tank which is normally fllled to $1 / 2-1$ nch depth. Observations of these waves are made visually, by st1ll and motion plctures, and by speclal electric depth gauges which give a continuous record on an osclilograph.

(h) The project 18 progreselng aotively.

(1) The results of the work to date are given in report $\mathbb{N}-54$ of the Hydrodynamics Laboratory ent1tled "Progress report of the analogy between surface shock waves and liquids and shocks in compreselble gases", by H. A. Elngtein and Earl G. Baird.

(18) (660) DEVELOPMENT OF A HOT WIRE VELOCITY KETER FOR USE IN WATER.

(b) Research D1v1sion, So1l Coneervation Service, U. S. Dept. of Agriculture.

(h) Thls project has been discontinued, due to lack of personnel. 
UNIVERSITY OF CALIFORNIA, College of Agriculture, D1vision of Irrigation, Dav18, Cal11.

Inquiries concerning projects No. 19 to 24 , 1ncl, should be addressed to Prof. F. J. Velhmeyer, College of Agrioulture, D1v1sion of Irrigation, Dav18, Cal11.

(19) (270) THE EFFECT OF THE DEPTH OF WATER TABLE UPON THE ABILITY OF PLANTS TO EXTRACT WATER.

(b) California Agricultural Experiment Stat1on.

(c) L. D. Doneen, R. M. Hagan, A. H. Hendrickson, F. J. Velhmejer.

(e) Experiment Station project.

(1) The work under this projeot is now designed to determine the ab1lity of plants to survive and extract water under water-logged conditions.

(g) The tank equipment described in previous reports 18 st1il being used. The Invest1gations have been enlarged, bowever, to study the diffusion of gases through solls under varlous soll-molsture conditions.

(b) Project is in active status.

(1) No published reports.

(20) (271) MOVEMENT OF WATER THROUGH SOILS.

(b) California Agricultural Experiment Station.

(c) L. D. Doneen, R. M. Hagan, A. H. Herdrickson, C. N. Johnston, F. J. Velhmeyer.

(e) Experiment station project. Part of project on principles of soll molsture in relation to irrigation.

(P) The movement of water through solls 18 studied under various conditions and the ablilty of the soll to auply water to plants through caplllary movement.

(g) Flsld and laboratory equipment 18 belng used for these studies.

(b) Investigations are in active status.

(1) The following reports have been publ1shed:

"The determination of mo1sture in undisturbed so11." N. E. Ediefsen and W. O. Sm1tb. Proc. So11 Sc1. Soc. Amer. 8: 112-115. 1944.

"Use of tenslometers in measuring avallabllity of water to plants." F. J. Velhmeyer, N. E. Edlefsen, and A. H. Hendrlckson. Plant Physiol. 18(1): $66-78$.

"Experts discuss varlous methods of orchard sult1vation." F. J. Velhmeyer and A. H. Hendr1okson. Almond Facts 9(3): 1,7. May-June.

(21) (272) STUDY OF HYDRAULICS OF SPRINKLING SYSTEMS.

(b) Cal1 Pornia Agriculturel Experiment station.

(c) J.B. Brown, C. N. Johnston, A. Molenaar.

(e) Experiment Station project.

(1) Determination of the characterist1os of jets and the distribution of water from sprinklers.

(g) Fac1l1t1es in hydraulic laboratory are being used for the study of reaction or jets.

(b) Project 18 in active status. Th1s 18 part of a larger project on the improvement of farm 1rrigation systems.

(1) The following reports have been published:

"Hydraulics of sprinkl1ng systems for 1rrigation." J. E. Christiansen. Trans.A.S.C.T. 107: 221-250. 1942.

"Irrigation of sugar boets by sprinkling." J. E. Christiansen. Spreckels sugar Beet Bul. 6(5): 29, 34-5. 1942.

"Irrigation by sprinkling." J. E. Christiansen. Cal11. Agr. Exp. Sta.

BuI. 670. 1942. 
(22) (666) STUDY OF THERMODYNAMICS OF SOIL MOISTURE.

(b) Californie Agricultural Exporiment station.

(c) R. M. Hagan, A. H. Hendr1ckson, C. N. Johneton, F. J. Velhmeyer.

(e) Experiment Station project.

(i) Studies are belng made of methods of measuring soll molsture and the abll1ty of soll to supply water to plants.

(g) To determine the avallab1lity of water to planto.

(b) Project is in active statue.

(1) The followlng reports have been publ1shed:

"Volume-freezing-polnt relations observed w1th new dilatometer techn1que." Alfred B. C. Anderson and N. E. Edlefeen. So11 sc1. 54(3): 221-232. 1942. "The electr1oal capacity of the 2-electrode plaster of Par1s block as an Indicator of bo11-molsture content." Alfred B. C. Anderson and N. E. Edlefien. So11 Sc1. 54(1): 35-46. 1942.

"Laboratory study of the response of 2 - and 4-electrode plaster of Par1s blockB \&B Bo1l-mo1eture content indicators." Alfred B. C. Anderion and N. E. Edlefsen. Soll Sc1. 53(6): 413-428. 1942.

Water-permeable jacketed thermal radiators a indicators of fleld capaolty and permanent w1lting percentage in bo1le." C. N. Johneton. Soll So1. 54(2): 123-126. 1942 .

"Fleld study of response of the electrical resistance of 2- and 4-electrode plaster of Parls blook to variations in soll molsture." N. E. Ediefsen, Alired B. C. Anderson, and M. B. Marcum. Soll Sc1. 54(4): 275-279. 1942.

"Soll-mo1sture conditions and phenomena in Prozen 60118." Report of Committee on Phys1c8 of So1l-No1sture, 1941-42. N. E. Edlefsen, Cha1rman. Trans. American Geophybical Union, Pt. II: 356-371. 1942.

"Thermodynamlcs of 8011 molsture." N. E. Edlefsen and Alfred B. C. Anderson. H1lgardia 15(2): 31-298. 1943.

"A method of determining soll-molsture content based on the variation of the electrical capacitance of 8011, at a low Irequency. With molsture content." Alfred B. C. Anderson. Boll Sc1. 56(I): 29-41. 1943.

"The role of the pF in the dynamics of soll-molsture." Report of Committeo on Physics of So11-Mo1sture, 1943-44. F. J. Viehmeyer, Chalrman. Trani. Amer1can Geophys1cal Un1on, Pt. V: 699-712. 1944.

"Permanent w1lting percentages of solls obtalned from fleld and laboratory trials." A. H. Hendrickson and F. J. Ve1hmeyer. Plant Phys101. 20(4): 517-539. 1945.

(23) (667) HYDRAULICS OF IRRLGATION SUPPLIES IN CALIFORNIA.

(b) California Agricultural Experiment Station.

(c) M. R. Huberty, C. N. Johnston, A. Molenaar, A. F. P11lsbury, V. H. Scott, F. J. Velhmeyer.

(e) Experiment Station project.

(f) The effects of denudation of waterehods upon the water rofimen of typlcal grazing areas in Callfornia are being studied.

(g) Experlmental plots and small watersheds have been equippod with meacuring devices. These experlments are belng conducted under various conditions of Bo11, topography, and vegetation in Northern and Central California.

(h) Project 18 in active status.

(1) The following report has been published:

"So11-mo18ture records from burned and unburned plots in cortaln graglne areas of Colifornia." F. J. Velhmeyer and C. N. Johnston. Trans. American Geophysical Union, Pt. I: 72-84. 1944.

See also Project No. 27 of University of California, College of Agriculture, Division of Irrigation \& So1le, at Los Angeles, Cal1f. 
(24) MEASUREMENT OF IRRIGATION WATER, AND IMPROVEMENT IN FARM IRRIGATION STRUCTURES.

(b) California Agricultural Experiment station.

(c) J. B. Brown, C. N. Johnston, A. Molenaar.

(e) Experiment station project.

(f) To develop and Improve the des1gn of water-messuring dev10es and to prov1de inexpensive means for determining rates of flow.

(g) Fao111t1es of well-equipped hydral1c laboratory are being used.

(b) Projeot 18 in active status.

(1) The following reports have been publ1shed:

"The portable 1rrigation siphon and a new priming valve for siphons." C. N. Johnston. Californ1a Agr. Exp. Sta. Lithoprint, 4 pages. 1945. "Irrigation wells and well-drilling methods in Cal1fornia." C. N. Johnston. Cal1forn1a. Agr. Exp. Sta. C1r. 361. 1945.

"Farm 1rrigation structures." C.N. Johnston. Cal1fornia Agr. Exp. Sta. C1r. 362. 1945.

"A new portable pleld water meter and a new furrow water meter." C.N. Johnston. California Agr. Exp. Sta. Lithoprint, 7 pages. $1945^{\circ}$

"A new 1rrigation ploat meter for conorete plpe 11nes." C. N. Johnston. Cal1fornia Agr. Exp. Sta. Lithoprint, 7 pages. 1945.

"A new priming valve for portable slphons." C. N. Johnston. Agr. Engln. 27(1): 31-32. 1946.

"A. new portable pleld water meter and new furrow water meter." C.N. Johnston. Agr. Eng1n. 27(1): 29-31. 1946.

"A ploat meter for concrete plpe 1rrigation system outlets." C.N. Johnston. Agr. Eng1n. 27(5): 228-230. 1946.

"Comparison performances of metall1c and plast10 s1phons for 1rrigation." C. N. Johnston. Agr. Eng1n. 27(10): 469-470. 1946.

(25) (1157) PHYSICAL AND CHEMICAL FACTORS AFFECTING SOIL INFILTRATION RATES.

(b) California Agricultural Experiment station.

(c) L. D. Doneen, M. R. Huberty, A. F. P11lsbury, F. J. Ve1hmeyer.

(d) Prof. M. R. Huberty, Unlversity of Cal1fornla, Los Angeles 24, Cal1f.; or Prop. F. J. Velhmeyer, College of Agriculture, Dav1B, Cal1f.

(e) Experiment Station project.

(1) To atudy factors affecting soll inflitration rates with particular reference to the quality of 1rrigation water.

(g) Numerous Investigations in the fleld and laboratory are being conducted.

(h) Project 18 in active status.

(1) The following reports have been published:

"Compaction in cultivated s011s." M. R. Huberty. Trans. American Geophy 1 cal Union, Pt. VI: 896-899. 1944.

"Factors in permeab111ty changes of 80118 and 1nert granular material." Arthur F. P111 abury and Dav1d Appleman. Soll Sc1. 59(2): 115-123. 1945.

"Sulfur and ammoniacal fert1lizers on 11ght s011s of Kern County." L. D. Doneen and M. A. IIndsay. Spreckels Sugar Beet Bullet1n 10(5): 35. 39-40. Sept. - Oot. 1946.

"gulfur and ammoniacal fert1lizers produce acid so1ls in Kern County." L. D. Doneen and M. A. Indsay. Pac1flc Rural Pres8. June 22, 1946.

See also Project No. 28 of University of Callfornia, College of Agriculture, Division of Irrigation \& So1ls, at Los Angeles, Cal1f. 
UNIVERSITY OF CALIFORNIA, Collage of Agriculture, Div1sion of Irrigation and So11s, LOs Angeles, Cal11.

Inquir1es concerning Projeots No. 26 to 28, 1ncl., should be addressed to Prof. H. R. Huberty, University of Cal1forn1a, Los Angeles 24, Cal11.

(26) DRAINAGE INVESTIGATIONS IN COACHELLA VALLEY, CALIFORNIA.

(b) Present work cooperative between Coachella Valley County Water D1str1ct, Coachella, Cal1f.; Reglonal Salln1ty Laboratory, U. S. Dept. of Agrlculture, R1vers1de, Cal11.; U. S. Bureau of Reclamat10., Reg1on III, Boulder C1ty, Nev.; and Un1versity of Cal1fornia, College of Agr1oulture, Los Angeleg.

(c) J. H. Snyder (for the Distrlot), H. E. Hayward (for the Regional sal1nity Laboratory), C. I. Sweet (for the Bureau of Reolamat1on), M. R. Huberty and A. F. P1llsbury (for the University).

(e) Experiments on whlch to base future design.

(1) Dralnage problema are ant1cipated to develop with the advent of colorado River water for 1rrigation in the Valley. Purpose of Investigation is to establ1sh nature of and changes in the shollow ground water regime; to establ1sh the horlzontal and vertical permeabllity of the varlous strata with1n about 100 feet of the surface; and to establ1sh the most feasible dralnage methods w1th essent1al design information on each.

(g) On a grid network over the trough of the valley, a network of plezometers (observation wells) w1ll be established. At each location, plezometers w1ll be placed to tap each of the varlous independent acting aquifers found, the nature of the strata 1111 be logged, and plezometrlc surfaces w1ll be perlodically measured. Experimental dralnage un1ts of varlous types w11l be installed and operated, obtaln1ng prequent measurements of yleld, effect on plezometric surfaces at varlous depths and at varlous distances from the unit.

(a) Experiments on the p1rst experimental drainage well have been completed, whlch served to establish the technique for Installing plezometers and logging the strata encountered, to point out deflelenoles in the methods for drilling and developing such dralnage wells in thls locallty, and to establish the permeablilty of one of the groups of strata encounterad. Balance of work 18 in the planning stage.

(1) A report on the method of plezometer 1nstallation 18 being prepared for publication. The followlng report has been prepared:

"Hyarologlc studies in Coachella Valley, Callfornla." M. R. Huberty, A. F. Plilsbury, and $V$. P. Sololoff. University of California, Los Ángeles 24, Cal11. 49 pager, 6 198, m1meographed. March 1945.

(27) HYDROLOGICAL EFFECTS OF RANGE MANAGMENT PRACTICES.

(b) Laboratory project, but coordinated with eldilar work by the station under F. J. Velhmejer at Dav18.

(c) A. F. P1llsbury.

(e) Experimental work.

(1) To evaluate the effects of brush burning for the purpose of promoting range forage on the 1nflitration and run-off of preclpitation and on 8011 erosion In brush and brush grassland areas of Southern California.

(g) Plots and small watersheds are establishod on typlosl upland range land w1th two types of soll and two types of cover (chaparral and ohamlse) whereln run-off and erosion are measured. Plots and watersheds are established in pans to permit compar1son of no-burning and burning, and as to the time any such effeot persists. Comparat1ve measurements of inflitration are made on burned over and unburned areas.

(h) A continuing project.

(1) No I1nal data avallable. Some prellminary data procured from accldental burns have been made avallable to a State committee now preparing a report on the problem.

See also Project No. 23, University of Callfornla, College of Agriculture, D1v1s1on of Irrigation, Dav1s, Ca111. 
(28) PHYSICAL AND CHEMICAL FACTORS AFFECTING SOIL PERMEABILITY.

(b) Laboratory projeot.

(c) M. R. Huberty, A. F. P11lsbury.

(e) General researoh project, but with practical applications in the flelds of 1rrigation, drainage, and conservation stressed.

(f) To obtain factual data for the 1mprovement of 1rrigation, drainage, and reolamation practioes, and for the improvement of the epficiency of irrigation water conveyance and distribution.

(g) The work oovers the general fleld of factors affecting permeability of solls and the foroes involved, to some extent as regards saturated flow but malnly as regards unsaturated flow. Both fleld and laboratory work are under way. Specific factors investigated include: The effect of entrapped alr on permeab1lity; the effeot of compaction upon permeablilty; the effect of varlous factors on compaction; the effects of various inorganio fert1l1zers, so11 amendments and oultural practioes on permeab1lity; and the effects of the chemical constituents of irrigation waters on permeab1lity.

(b) A continuing project.

(1) The following reports have been prepared:

"Sol1d, 11quid, gaseous phase relationships of solls on whlch avocado trees have declined." M. R. Huberty and A. F. P1llsbury. Proo. Amer. Soc. for Hort. Sc1., 42: 39-45. 1943.

"Compaction in cultivated s011日." M. R. Huberty. Trans. Amerioan Geophys1 cal Union, Pt. VI: 896-899. 1944.

"Factors in permeab1l1ty changes of so11s and inert granular material." A. F. P1llsbury and D. Appleman. So11 So1. 59: 115-123. 1945.

See also Projeot No. 25. University of California, College of Agrioulture, Div1sion of Irrigation, Dav1s, Calif.

(29) FARM IRRIGATION BTRUCTURES.

(b) Laboratory project.

(o) A. F. P11lsbury.

(d) Prof. A. F. P1llobury, University of California, Los Angeles 24, Cal11.

(e) Experiment Station project.

(f) Improvement in the design and operating performence of farm pipe lines, control structures, and sprinkler systems.

(g) Laboratory investigation of factors affecting fallure of plain concrete irrigation pipe lines, being primarily a study of the factors affecting expansion coefflolents of the pipe, fleld tosting of various devioes for automat1cally controlling Ilow in concrete irrigation pipe ines; Ileld and laboratory tests of the operating characteristics of sprinslers as regards distribution patterns and hydraulic efficienoy; and pleld tests of the hyaraulic charaoterietios of multiple aprinkler unite.

(h) A continuing projeot.

(1) Essentially all work is in 1 ts initial stages.

UNIVERSITY OF GAIFORNIA, College of Englneering, Fluid Mechanios Laboratory, Berkeley 4, Callf.

Inquiries concerning Projeots No. 30 to 46, 1ncl., should be addressed to the Chalrman, Department of Englneering, University of dallfornia, Berkeley 4, Cal1f.

(30) (1272) ARTIFICIAL ROUGHNESS IN OPEN CHANNELS.

(b) Laboratory project.

(o) J.W. Johnson.

(e) Experimental 1nvestigation; undergraduate thesis.

(P) Investigation of methods to measure roughness.

(g) Experimental investigations in water channel containing various types of artiflcial roughness. 
(h) Two theses and two publications oompleted since 1942.

(1) "A study of the distribution of frictional energy losses in open channels." M. E. Fuller and R. E. Graham. B.S. thes18. 1942.

"Friction losses in artificlally roughened channels."A. C. Smith and C. Warren. B.S. thes18. 1943.

"Rectangular art1f1clal roughness in open channels." J. W. Johnson. Trans. Amer1can Geophysical Union, Pt. V: 906. Apr11 1945.

"Flow in a channel of definite roughness." D1scussion by J.W. Johnson and E. A. LeRoux. Proc. A.S.C.E., Vo1. 71, No. 6: 948. June 1945.

(31) (1271) STUDIES IN FLOW THROUGH POROUS MEDIA.

(b) Laboratory 1nvest1gation.

(c) E. Glenbot, R. U. White, W. E. Padelford, K. S. Plater. (e) Student thoses.

(f) Measurement of the critlcal gradlent whlch would exlat at the toe of an earth 1111 dam or levee.

(g) Water 18 forced vertlcally upward through a plpe packed with varlous anda of known porosit1es. Critical escape gradient 1 s noted when quicksand condit1on ex1sts.

(h) Two theses completed. Testing in progress.

(1) "Seepage studies." E. Glenbot. B.S. thes1s. 1942.

"Flow conditions at a dam." R. U. White and W. E. Padelfora. B.S. thee1s, 1943.

The following report has been publlahed: "Upllft pressure on dams. A sympos1um." M. A. Sel1m. Proc. A.S.C.E., December 1945.

(32) (1270) MIXING OF PARALLEL STREAMS.

(b) Prevlously in oooperation with A.S.C.E. Now a laboratory 1nveatigation.

(c) J. W. Johnson and others.

(e) Student theses and special studies.

(1) To determine the energy loss at the junotion of plpes of varlous a1zes, Junction angles, and discharge rat1os.

(g) Varlous welded junctions of 6,4 , and 2-1noh plpes have been prepared and are tested in a atandard p1p1ng arrangement consisting of two pumps, orlf1ce meters, and manometers.

(h) One thes1s, several special investigations, and one publication have been completed since 1942.

(1) "The mixing of two parallel streams of water in a closed conduit." $R$. I. Johnson. M.S. the $818,1942$.

"Flow character1st1cs of rectangular open-channel junctions." E. H. Taylor. Trans. A.S.C.E., Vol. 109: 893. 1944.

(33) FLOW DURATION CURVES.

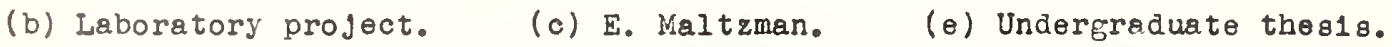

(1) To prepare flow duration curves for oerta1n atream in Southern California.

(g) Curves prepared Irom stream llow data published by the U. S. Geologlcal Survey.

(h) One thesis completed.

(1) "Flow duration ourves for stream in Southern Cal1fornia." E. Maltzman. B.S. thes18. 1943.

(34) NODEL STUDY OF BREAKWATER AT HUNTERS POINT, CALIFORNIA.

(b) Bureau of Yards and Docks, U. S. Navy.

(c) J.A. Putnam, K. J. Bermel, J.W. Johnson.

(e) A theoretical end experimental investigation.

(1) To provide information for locating breakwaters to give the maximum protection at this Navy Base against wave action from local winds, and then to determine th relative effects of silting and scouring should breakwaters be constructed.

(g) A relatively large scale model atudy was made to verify a theory of wave 
diffraction in the lee of breakwaters. The data from these studies then permitted the breakwaters to be located in the best position for wave protection, and a second model then was made to investigate silting and scourIng tendencles due to the breakwaters.

(h) Investigation in progress.

(35) OSCILLATORY WAVES.

(b) Laboratory project.

(o) J. W. Boucher.

(e) Graduate thesis.

(f) To obtain experimental information on the detalls of oscillatory waves in shallow water.

(g) Experiments w1ll be conducted in a wave channel 60. feet long, 3 feet deep, and 1 foot wide. Wave velocity, perlod, length, helght, mass transport and orbital velocities trrough deptin and length of channel will be measured and compared w1th theory.

(h) Work in progress.

(36) MODEL LAWS FOR HYDRAUL1C STRUCTURES.

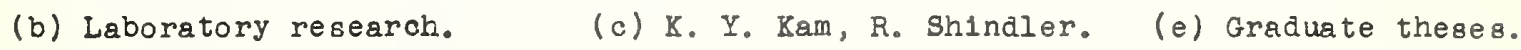

(f) To obtain experimental data for the design of models of hydraulc structures.

(g) The effect of scale, absolute alze and width, roughness, and other lactors w11l be inveatigated in the laboratory channels which are ava1lable.

(h) Work in progress.

(37) FLOW THROUGH LEVE'ES BY ELECTRIC ANALOGY.

$\begin{array}{ll}\text { (b) Laboratory project. } & \text { (c) J. H. Collart. }\end{array}$

(f) To obtain experimental data for design purposes.

(g) Flow nets for typical levee sections will be prepared in the electric analogy tank.

(h) Now in progres8.

(38) STRUCTURES EXPOSED TO WAVE ACTION.

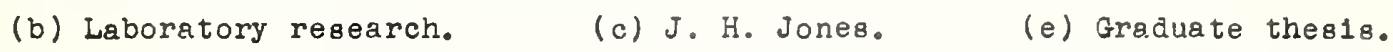

(f) To obtain experimental data for the design and location of such shore protection works as grolns, jetties, and bulkheads.

(g) Models of structures will be installed in the model basin and subjected to wave action. Variation will be made in groin apacing, wave characteristics, and sediment characteristics.

(h) Work in progress.

(39) BEHAVIOR OF TWO-PHASE FLUIDS IN POROUS WLDIA.

$\begin{array}{ll}\text { (b) Laboratory project. } & \text { (c) J. A. Putnam, F. G. M1ller, J. W. Gregg. }\end{array}$

(e) Experimental and theoretical research; Ph.D. and M.S. theses.

(f) To determine the nature and importance of the depaxture from equilibrium conditions for single and multiple component fluids whlch move through porous media under pressure gradients and which undergo a gradual phase change during the process.

(g) single component fluids, including water, ammonia, and propane, and a mixture of water and carbon dloxide, are made to plow through uniformly packed, unidirectional, insulated sand colums. The flulds enter as a single 11quid-phase but experience a phase change as lower pressures are encountered downstream. Measurements are made of pressure, temperature, and liquid saturation as a function of distance. The theoretical investigation 18 being based on reaction rate considerations.

(h) Two M.S. theses completed; one Ph.D. and one M.S. thesis in progress.

(1) "The two-phase flow of ammonia in porous meala." H. G. Spencer. M.S. thesis, 1945.

"Two-phase flow of water through porous media." J.J. Kraukl1s. M.S. thes18, 1943. 
The following report has been published: "Two-phase, two-component flow in the viscous reglon." R. C. Mírtinell1, J.A. Putnam, and R. W. Lockhart. Trans. Am. Inst. of Chem. Engrs, Vol. 42, No. 4: 681. August 25, 1946.

(40) FLOI OF SOLID-GAS MIXTURE IN PIPES.

(b) Laboratory projeot.

(c) L. Farbar.

(e) Experimental investigation to obtain design data.

(1) To deternine presgure drop aocompanying flow of alr, conta1ning large concentrations of ultra-fine solid particles (e.g., catalyet) through pipes, and to investigate problems of metering such mixtures.

(g) Recirculation of air and catalyst through piping containing one vertical run and two horlzontal runs of different diameters. Catalyst to be metered gravlmetrlcally as fed, air to be metered by standard nozzlo.

(h) Apparatus designed and under conetruction.

(1) Some tentative erpirical data under operating conditions ava1lablo at looal oll refineries.

(41) PRESSURE DROP ACCOMPANYING TWO-PHASE, TWO-COMPOHENT FLOW IN PIPES.

(b) Laboratory project. (c) J.A. Butnam, F. D. McElwee.

(e) Theoretical and experimental 1nvestigations. Graduate thoses.

(f) To determine the transition conditions under whlch the gas and/or liquid phases are flowing in viscous and/or turbulent motion or in slug flow for 1sothermal flow in horlzontal and vertical plpes.

(g) Mixtures of air and varlous liquids are made to flow through tubes at varlous orlentations. Pressure drop and fluld distribution are determined for a range of liquid and gas rates whlch may be controlled separately.

(h) Some theoret1cal work is nearly completed. Apparatus 18 belng reoonstructed w1th a view to determining the above-stated object1ves. Five graduato theses completed.

(1) Bressure drop accompanying two-component flow through pipes. I. M. Z. Boelter and R. H. Kepner. Ind. and Eng. Chem., Vol. 31: 426-434. 1939. "Isothermal pressure drop for two-phase, two-component flow in a horlzontal p1pe."R. C. Mart1ne111, L. M. K. Boelter, T. H. M. Taylor, E. Q. Thomsen, E. H. Morrin, Trans, A.8.M.E., Vol. 66: 139-151. 1944.

"Two-phase, two-component flow in the viscous region." R. C. Martinell1 J. A. Putnam, and $R_{.}$W. Lockhart. Trans. Am. Inst. op Chem. Eng., Vol. 42, No. 4: $681-705.1946$.

(42) UNSTEADY FLOW IN CONNECTING PIPEB.

(b) Laboratory project.

(o) R. G. Folsom.

(e) Theoretioal and experimental investigation for general information.

(1) To develop caloulation methods and charts for the solution of amplitude changes and phase shifte between the water elevations in two reservolrs connected by a long pipe.

(g) From theoretical conslderations, a serles of charts with dimensionless coordinates w1ll be developed to give the amplitude and phase of the water surface elevation in a small gage well with respect to a large reservolr. Experimental data vill be obtalned from laboratory equipment and a study made of differences with respect to the theoret1cal values.

(h) Theoretioal and experimental work partially oompleted.

(43) A BITOT TUBE STANDARD FOR FLOW MEASUREMENT.

(b) In cooperation w1th Turbine Pump Manufacturers" Assn.

(c) R. G. Folsom.

(e) Design and experimental investigations.

(f) To develop a satisfactory Pltot tube and standard code for use in fleld teating of pumps.

(g) To design, construot, and callbrate a sultable pltot tube and use 1t under a varlety of conditions.

(h) Work in progress. 
(44) THE SMALL WATER TUNNEL.

(b) Laboratory project. (c) R. G. Folsom, K. J. Bermel.

(e) Design and construction of experimental facilities.

( $P$ ) To provide laboratory facilities for studies on cavitation, ship propellers, ourrent meters, eto.

(g) The design w1ll include a measuring section of about 24 inches in diameter.

(b) Work just starting.

(45) (726) PUMP TESTING LABORATORY.

$\begin{array}{ll}\text { (b) Laboratory project. } & \text { (c) R. G. Folsom. }\end{array}$

(e) Research in the genera]. Ileld of pumping liquids.

(P) To 1mprove design methods and performance of pumps.

(g) Theoretioal and experimental investigations.

(b) Work to be started again in fall of 1947.

(1) During the war period, the only work completed on this project was the development of a special pump for the Navy.

The following report has been published:

"Plpe line flow of solide in suspension. A symposium. Effeot on the characterletics of centrifugal pumps." L. C. Falrbank, Jr. Trans. A.S.C.E., Vol. 107: 1563. 1942.

(46) STUDY OF VELOCITY AND TEMPERATURE FLUCTUATIONS IN FULLY DEVELOPED AXISTMMETRIC TURBULENT FLOW OF A LIQUID.

(b) Laboratory project. (a) L. M. Grossman.

(e) Experimental and theoretical investigation.

(f) To measure veloolty components and temperatures in the turbulent plow of a 11quid in a tube in order to explain the mechanlem of transport phenomena in fully developed axisymetric turbulence.

(g) Velocity pluotuations will be determined by measuring the potentials induoed In an electrolyt10 11quid outting an A-C magnetio fleld and temperatures by means of a sensitive thermocouple. Spatial correlation coeffiolents will be found $a s$ well as the turbulenoe spectrum for liquid flow in a plpe, the object belng the clarification of a non-1sotropic turbulence theory for the axisymmetric case.

(h) Apparatus being assembled.

(1) The experimental technique $1 \mathrm{~s}$ besed on the method of induced potentials in a conducting liquid discussed in the following papers:

"The induction of electromotive foroes in a moving liquid by a magnetio fleld and its application to an investigation of the flow of liquids." E. J. Wliliams. The Proceedings of the Physical Soolety, 42: 466-478. August 1930.

"Methode zur elektrischen Geschwindigke1tsmessung von Füselgke1ten."

B. Thurlemann. Helvetioa Phys10a Acta 14: 382-419. 1941.

"An alternating pleld induotion flow meter of high sensitivity." A. Kohn. The Review of Sclentiflc Instruments, 16: 109-116. May 1945.

(47) GRAVITY WAVES AND RELATED PHENOMENON.

(b) Bureau of Sh1pв, U. S. Navy.

(c) M. P. O'Brien, R. G. Folsom, J. W. Johnson, J. A. Putnem, H. W. Iversen.

(d) Bureau of Shlps, Navy Dept., Washington 25, D. C.

(e) A theoretical, laboratory, and pleld investigation on the generation and forecasting of waves, surf conditions, measurement of waves, eto.

(f) To develop methods of forecasting wind waves and swell, surf conditions, and beach changes; measurement of wave characterlstics; and make laboratory and pleld invest1gations to provide experimental ohecks and other information. 
(g) The wave channel, model basin, and other facilities ars used in the laboratory invest1gations. The flela party obta1n information along the ent1re Pacific Coast and cooperate with Naval vessels in obtaining information at sea.

(b) Work in progress.

(1) Approximately 225 technical, laboratory, and progress reports have been submitted to the Navy since starting this work in June 1944.

The following reports have been published:

"A sumary of the theory of oscillatory waves." M. P. O'Brien, M. A. Mason, and staff of the Beach Erosion Board. Beach Erosion Board, Offlce of the Chlef of Englneers, Technical Report No. 2. 1942.

"The effect of wall-frlction on gravity waves." M. P. O'Brien and A. D. Chaf1n, Jr. Trans. American Geophysical Union, Pt. I: 84. 1942.

\section{UNIVERSITY OF CALIFORNIA, Department of Engineering, Los Angelos 24 , Cal1f.}

(48) FOG INVESTIGATION - FOG NOZZLE STUDIES.
(b) U. S. Forest service.
(c) E. H. Taylor, G. Young.

(d) L. M. K. Boolter, Dept. of Engineering, University of California, Los Angeles 24, Calle.

(e) Experimental project.

(f) To obtain spec1f1c information on the performance and behavior of certain comercially obtainable epray nozzles used in fire pighting.

(B) The immediate objective of this program is to provide data relative to the gmount of water delivered at a number of predetermined pressures from a series of about one hundred test units. Information regarding the distribution of water within the spray is also obtained. This is done qualitatively by means of photographs and quantitatively by means of a speolaliy designed sampling trap.

(h) Testing completed; report in progress.

UNIVERSITY OF SOUTHERN CALIFORNIA, Researoh Foundat1on for Cross-Conneotion Control, Los Angeles 7, Calir.

(49) RESEARCH FOUNDATION FOR CROSS-CONNECTION CONTROL.

(b) Laboratory project by Un1versity of Southern Cal1fornia.

(c) R. E. Vivian, E. M. Cloran.

(d) Research Foundation for Cross-Connection Control. Attention Robert E. Vivian, Director, University of Southern California, University Park, 3551 Un1versity Avenue, Los Angeles 7, Cal1f.

(e) General experimental research.

(i) To Bupplement and evaluate existing information on meohanioal backflow prevention devices operating under constant line pressure, and related matters.

(g) Field investigation covering operation and maintenance of over 4000 backflow prevention devices already locally installed. Development of standard technique for the testing of double check valve installations; establishment of standardized laboratory and pleld test procedures and mínimum specif1oation requirements for backflow prevention equipment; field and laboratory research on material corrosion and deterioration, supplemental researoh on vacuum conditions, plpe sling, and corrosion; industrial and domestic water pollution problems in relation to oross-connection control and back8lphonage prevention; head losses in backflow prevention equipment; malntenance of minimum pressures in distribution systems, in relation to backslphonage prevention and cross-connection control. 
(b) A year and a half has been devoted to fleld and laboratory researoh. A paper 1s be1ng prepared, to be avallable about May 1, 1947, wh1 oh w111 oontaln certain conolusions and recommendations ooverlng lield testing methods, and minimum speolfloations for backlow prevention devices operating under pressure.

(1) No reports or publications have been 1 ssued to date.

CARNEGIE INSTITUTE OF TECHNOLOGY, Department of C1V1l Engineering, Schenley Park, P1ttsburgh 13, Pa.

(50) STILLING BASINS FOR DAMS.

(b) Laboratory project. (o) T. T. Mavia, L. M. Laushey.

(d) Prof. F. T. Mav1s, Head, C1811 Eng1neer1ng Depto, Cerneg1e Inst1tute of Teohnology, P1ttsburgh 13, Pa.

(e) Graduate thesis.

(P) To determine the effeot of an end 611 in the formation of a hydraulio $\mathrm{jump}$.

(g) Tallwater deptho required to for a jump w1th varloue $8111_{s}$ on the apron are fe und by experiment and compared with depths required without a 8111.

(h) In progress.

COLORADO A \& M.COLLEGE, C1V1l Eng1neering Department, Fort Collins, Colo.

(51) (1090) TALL VELOCITY APPARATUS.

(b) Laboratory projeot.

(o) D. F. Gunder.

(d) Dr. D. F. Gunder, Colorado A \& M College, Ft. Collins, Colo.

(e) The project 18 an experimental study only.

(f) This project was designed to give a rough cheors on the effectireness of the hydraul10 sand separator projeot.

(g) The project required the design of an apparatus by wh1oh a direct measurement of fall veloolt1es of sand part1oles in water could be measured. A graduated luclte tube was 11tted with a mechanlcal device for dropplng small quant1ties of sand 1nto the tube. The fall veloclty was measured by visual observation of transit of partioles across the graduations with timings by a stop watoh.

(b) Project inaot1ve.

(52) (1089) HYDRAULIC SAND SEPARATOR.

$\begin{array}{ll}\text { (b) Leboratory project. } & \text { (c) D. F. Gunder, E. F. Serr. }\end{array}$

(d) Dr. D. F. Gunder, Colorado A \& M College, Ft. Coll1ns, Colo.

(6) The project is a combined theoretioal and experimental study whiob, 11

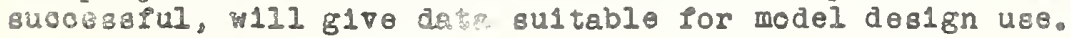

(2) It 1s the objeot of this project to devise a method of olaesifying sands on the basis of fall velocity $1 \mathrm{n}$ water. If a method of dolng thls can be dev18ed, 1t w11l then bo poesible to analyze sand samples into clareses according to pall veloolty and pinally to maro up new samples sogled to ang deslred sall veloc1ty.

(g) An apparatus has been deslgned and bullt whlch olasslfles sands accoralng to pall veloolty by a continuous flotation prooess. The prooess 1s purely dynanic in that the sand 1s 1ntroduced drectly into the plow. Cheoling of the apparatus for duplioation of results 18 nearly completed. A etat1stioal theory of separation 18 belng cheoked and a study of the behavior of tho apparatus under varying Reynoide numbers 18 under way.

(b) Prolect 18 active. 
(53) SAND TRAPS AND SLUICEWAYS.

(b) U. B. Soll Coneervat1on Bervioe, Colorado Agrioultural Experiment stat1on, Colorado A \& M Colloge.

(c) R. L. Parshall.

(d) Ralph L. Parehall, U. B. Soll Consorvation Sorvioo, Colorado A \& M College, Ft. Collins, Colo.

(o) Experimental project for design purposes.

(1) To 1mprove the epploleney of present deslgns of sand traps uelng vortex tubes, rifles, and dellectors, alore or in combinations. To perfect a

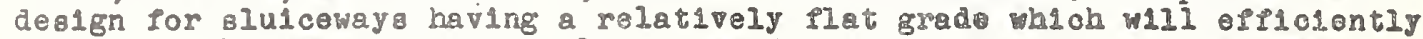
transport the efluent material from sand traps to a polnt of disposal.

(g) Prev10us work w1th rortex tubes has demonstrated thelr effectivenesa ginon the length 1s less than 16 peet. pith lengthe exceeding 16 peet, epfoctive ness decreases, and to provido dasign for v1de canals, lateral movemsn op bed load to vorter tubes by means of rifples and deploctors is belng employed oxperimentaliy. Model are used in the laboratory which lend therselves to changes of design and permit vigual study of the action attained. By introduoing varlous alzes of sand or ground coal in wessurod quantities and measuring the capture, reasonable quantitat1ve resulte bavo been obtained. Prototypo a1zos can be terted in part at a rivarside bydrau110 laboratory. Sowe experimente havo been made in producing vort10al plow in sluloovay.

(h) There have been numerous 1181d applicat10ng of the rortex tube sand trap whlch have Punctioned satlafactorily in relatively gmall canale. The woris st1Il to be done 18 that of remov1rig bed loade from largo osnals. A large trap is belng contemplated for conetruction in 1947 near grosno, Cal1s., In canal ioo feet wide. A design ha been oppored guploying omblnation of reveral units based on model experiment.

(54) MTASURING DEVICE AND INTEGRATING INBTRUMEHT.

(b) U. 8. Soll Conservation sorvice, Colorado AgrloulturaI Fxporimont 8tation.

(o) R. L. Parshall, C. H. Rohmer.

(d) Ralph I. Parshall, U. 8. 801I Consorvation Bervioo, Colorado A M Colloge, Ft. Collins, Colo.

(e) Experimental project for design purposes.

(1) To perfect a practical, efflolent and dependable combination moanuring dev108 and recording instrument of simplo design and construction, whereby form delivery of Irrigation mater may bo aocurately measurad and the total volume be totalized over any period or tims.

(g) It 18 anticlpated that the prinolple of measuring flow by means of a short tube or an adjustable tube or1P10e 111 bo employed 28 the basio for doalgnIng and construoting an integrating instrument. The dogign of the integratIng Instrument vill probably not include the slement of time.

(b) Mo Mork done in 1946.

(1) Conslderable work has boen done in the past on an adjustable tubs gate and more recently on turbine perforinaroe in ahort tubes.

(55) (1081) SNOW COURSE MEASUREMENTS AND FORECAST ANALYGES.

(b) U. 8. So11 Conservation Service, V. S. Bureau of Rrclamation.

(o) R. L. Parshall, H. stookwell.

(d) Ralph L. Parshall, U. S. Soll Coneorvation Service, Colorado A \& M Collgge, Ft. Colldns, Colo.

(o) Bystemat10 measurements of depth and water content of the onow at high elevations in the mountain areas of Colorado for the purpose of foreoasting the surrer runoff in the main rivers of the State in the interest of 1rrigetion, power, domest1e suppl1es, and other uses.

(1) To supply information as to the probable water apply for the coming irrigation bearons. 
(g) Measurement of depth of the water content of snow along many permanenty established snow courses is made systemat1cally throughout the winter months. Data on other attending conditions affeoting runoff are also gathered. These measurements are compared with slmilar data obtalned in previous years to establish a basis of forecasting probable spring and summer runofe.

(b) Thls is a continuous project with no plans for termination.

(56) MEASUREMENT OF FRICTION LOSSES IN PIPES AND FITTINGS USED IN IRRIGATION PUNPING PLANTS.

(b) U. S. Soll Conservation Service, Colorado Agricultural Experiment Stat1on, Colorado A. \& M. College.

(c) C. H. Rohwer, W. E. Code.

(d) Carl H. Rohwer, U. S. Soll Conservation Service, Colorado A. \& M. College, Ft. Collins, Colo.

(e) Experimental project for preparing designs of irrigation pumping plants.

(f) To determine the losses due to frlotion in gate valves and check valves 28 \& basis in choosing the propor type of these valves.

(g) Different sizes of valves are installed in the laboratory so that head losses due to friction are measured as the difference in head between the inlet and outlet. A pipe is installed through a bulkhead and $108 \mathrm{ses}$ are determined by means of hook gages as the difference in elevation between the pree water surfaces on each side. A valve 18 then attached to the plpe without otherwise changing the conditions and the routine is repeated. Gate valve losses are determined for one-fourth, one-half, three-fourths, and full opening. Measurement of discharge 18 made with a standard weir. From these data friction 108 ses for all rates of discharge are determined.

(h) Laboratory work will be completed during 1947.

(57) (1086) PHOTOGRAPHIC METHOD FOR MAKING SNOW SURVEYS.

(b) Laboratory projeot.

(c) M. Parshall.

(d) Maxwell Parshall, Colorado A. \& M. College, Ft. Collins, Colo.

(e) An experimental project for general information.

(f) To devise a more simple, quick; and economical method of snow surveying.

(g) A telephoto is made of a portion of a high mountain watershod. The percentage of area covered w1th snow is compared to the water content of the snow as determined contemporaneousiy in the vicinity by the standard method of snow surveying. The possibility of a correlation between the two factors $1 \mathrm{~s}$ beling 1nvest1gated.

(h) Data are st1ll being obtained. The project will be continued over a perlod of years to determine 1 ts rollability.

UNIVERSITY OF COLORADO, Department of CIV11 Engineering, Boulder, Colo.

(58) EFFECT OF LATERAL CONTRACTION OF SUPRRCRITICAL FLOW.

(b) Laboratory project.

(c) A. T. Ippen, J. H. Dawson.

(d) Dr. A. T. Ippen, Massachusetts Inst1tute of Technology, Cambridge, Mass.; or Prof. John H. Dawson, University of Colorado, Boulder, Colo.

(e) Theoretical and experimental 1nvestigation for general information on the wave formation in channel contractions.

(f) To enable desizners to more accurately design a contraction for a range of depthe and velocities that w11l give a minimum disturbance and wave action in the contraction and in the channel below the contraction.

(8) A tilting flume was constructed at the Fritz Englneering Laboratory and a second flume at the University of Colorado, both of whlch enabled the operator to get a uniform depth and velocity entering the contraction so as to give Froude numbers from 0 to 15. Information on the water surface elevat1ons was obtained by means of depth gages and photography. Experimental results checked the information obtalned by theoretical examination of the 
problen. It was found that a double reverse or $\mathrm{s}$ curve gave the largest waves and worst conditions for ali supercritical flows, while a etralght side wall would glve the best flow conditlons at supercritical flow and equally good results for subcritical conditions.

(h) Additional experimental results are belng obtained by Mr. Dawson and a report 18 being written by Dr. Ippen:

(1) "An analytical and experimental study of high veloolty flow in curved sections of open channels." Dr. A. T. Ippen. Thesis submitted at the Cal1 fornia Inst1tute of Technologj in 1935.

"The effect of lateral contractions on supercritical flow in open channels." John Howard Dawson. Thes1s submited to Lehigh University in 1942.

(59) FLOW PATTERNS AROUND BRIDGE SECTIONS.

(b) Laboratory project.

(c) J. H. Dawson.

(d) Prof. John H. Dawson, Unlversity of Colorado, Boulder, Colo.

(e) Experimental 1nvestigation giving qualitative results on flow patterns for general information.

(f) To determine the direction of flow and position of eddies in the flow past typical bridge sections so as to more adequately determine the aerodynamic characterlstics of the superstructure and determine the scour around the plers.

(g) Two-dimensional flow 18 obtained by passing a streaming birefringent (1n this case a collo1dal suspension of California Bentonite) between plates of plexiglas8. Two-dimensional models of the section to be studied are placed in the flowing Pluld and the stream pattern 18 made v181ble through the use of ciroularly polarized 11ght. Qualitat1ve results only are obtained and recorded by means of still and motion plotures.

(h) Excellent st11l and notion pictures have been obtained, some of which have been submitted for publication.

(1) "Fluid polar1scope." Fred Locher and J. N. Brady. Hydraul1c Laboratory Report No. 164, U. S. Bureau of Reclamation, Denver, Colo.

Photographs have been made showing vortex tralls, eddy formation and position, and flow characterlstics, using the fluld polariscope, for the following: orlfice meter, venturi meter, sharp edge.we1r, ogee splilway, hydraulic jump, and a range of I and channel sections. Prints are avallable at cost upon application to John H. Dawson, C1vil Englneering Dept., University of Colorado, Boulder, Colo.

COLUWBIA UNIVERSIIY, Flu1d Wechanics Laboratory, Department of C1v1I Engineering, New York 27, N. Y.

Inquiries concerning Projects No. 60 to 62 , 1ncl., shoula be addressed to

Prop. Borls A. Bakhmeteff, Fluid kiechanies Laboratory, Columbla University, New York 27, N. Y。

(60) (1253) FLOW OF FLUIDS TFROUGH GRANULAR (POROUS) HEDIA.

(b) Laboratory project.

(c) N. V. Feodorop, Research Assoclate, under direction of Prof. Bakhreteff.

(e) General theoretical and experimental research.

(1) To establ1sh rational generalized expressions for permeabllity of porous beds consisting of grains of unfform or mixed size.

(g) The present phase, dealing with flow of alr through beds of lead shot, sand, gravel, etc., is a continuation of the work systematically pursued alnce 1936 and interrupted by the war. It 18 antlolpated that the results will furnish material permitting presentation of an integrated account of the phenomenon as a whole.

(b) A continuing project.

(1) Previous papers and disoussions by Borls A. Baknmeteff and N1cholas V. Feodoroff: 
Journal of Applied Mechan108. Septembsr 1937 and June 1938.

Prooeedings Fifth Intsrnational Congress of Applied Mechan10s, Cambridge, Mass., 1938.

Trans. American Geophysical Un1on, Pt. II, 1943.

(61) ELECTROMAGNETIC VELOMETER.

(b) Laboratory project.

(e) General theoretical and experimental research.

(1) To develop instrumentation and technlque to record rellably and conveniently manifestations of turbulence in liquids, as well as to measure detalled velocity distributions in boundary layers, separation zones, etc.

(g) The approach $1 \mathrm{~s}$ based on the method of applying the principle of electromagnet1c 1nduction, as suggested and developed by Dr. A. Bolln, Research Assoclate, who conducted the project from 1943 to 1945 under the general supervision of Prof. Bakhmeteff.

(h) Temporar1ly suspended; ant1c1pate continuance in the near future.

(1) The following papers by Dr. A. Kolln indicate the pleld covered by the research:

"Electromagnet1c velometry." Journal of Applied Pbys1cs. February 1944. "An alternating pleld 1nduction plow meter of high sensitivity." Review op Sclent1f1c Instruments. May 1945.

"Mercury jet magnetometer." Rev1ew of scient1f1c Instruments. August 1945.

(62) HYDRAULICS OF SHORT FLUMES.

(b) Laboratory project.

(c) N. V. Feodoroff, Research Assoclate, under the direction of Prof. Bakbmetepf.

(e) General theoretical and experimental research.

(1) Investigations alming at disolosing the general behavior of water in short flumes with speclal emphas is on studyling boundary layers, as well as phenomena connected w1th separation, formation of rollers, etc.

(g) The studies resumed since the end of the war are in continuation of a chain of individual projects, partly in the form of graduate theses, carried on systemat1cally for over ten years and dealing with alfferent aspecto of hydraulics of broad-crested welrs, hydraulics of slulces, tallwater phenomena, hydraul1c jumps, etc.

(h) Except occaslonal publications, referred to under (1), the results are to be presented in systematic form in a special volume at present in an advanced stage of preparation.

(1) The material has been partly presented in the following disoussion by Prof. B. A. Bakhmeteff and N. V. Feodoropt, appearing in the Proc. A.S.C.E.:

"Proplle curves for open channel Plow." October 1942.

"Energy loss at the base of a Pree overpall." Apr11 1942.

"Hydraul1c design of drop structures for gully control." October 1942.

UNIVERSITY OF IDAHO, College of Engineer1ng, Moscow, Idoho.

(63) FRICTION AND CORROSION CHARACTERISTICS OF ALUMINUM TUBINQ.

(b) Aluninum Company of America and laboratory project.

(c) H.Bliokensderfer.

(d) Allen S. Jansien, Act1ng Dean, College of Englneer1ng, University of Idaho, Mo'scow, Idaho.

(e) Experimental for general information.

(P) To determine friction factor for flow of water and ablitty of aluminum plpo to resisi currosion of natural watsr. 
(g) Aluminum tubing of $812 \theta$ srom 1/2-1nch to 2-1nohes will be tested to determine bead 1088 due to friction for laminar and turbulent flow. Samples of the plpe w11l be exposed to waters of varlous mineral oontent and pH values in order to ascertain the abllity of aluminum to resist corrosion.

(b) Inactive at present t1me.

(1) Shortage of workers and naterial has delayed starting of testa. Most neoesary materlal and equipment is on hand and teats should begin within the next fow months.

UNIVERSITY OF ILIINOIS, College of Engineering, Urbana, IIl. .

(64) THE BACRWATER PROFILE FOR STEADY FLOW IN OPEN CHANNELS.

(b) In cooperation with the Wator Resources Branch of the U. S. Goologloal survey.

(c) W. D. Mtchell, W. M. Lansford.

(d) Pro1. F. B. Beely, Head, Department of Theoret1cal and Applied Hechan108, 214 Talbot Iaboratory, Un1versity of III1no18, Urbana, III。

(e) Experdmental otudy to obtain general information.

(f) To obtain information on backwater proflles of different roughness and varlous channel oross-sections.

(g) Thlo projeot 18 a continuation of research described under the backwater proplie for ateady flow In a rectangular channel, eto." Univeralty of Illinola, Completed Projeots, page 100.

(b) Just boginning.

(65) FLOW THROUGH MANIFOLD PORTS IN A PIPE.

(b) Laboratory project. (c) W. M. Onen, H. M. Lanaford.

(d) Prop. F. B. Seely, Head, Department of Theoret1cal and Applied Mechanios, 214 Talbot Laboratory, Undvera1ty of Ill1no1s, Urbana, IIl.

(e) Theoretioal and experimental.

(1) To obtain information on the flow through small porta in a plpe.

(g) Experimental work w1l be atudied and coordinated w1th published 1nformation in an endeavor to solve the problem.

(b) Works in progreas.

STATE UNIVERSTY OF IOWA, IOWa Inst1tute of Hydraul1c Research, Iowa C1ty, Iowa.

Inquirles concerning Projects Nos. 69 to 78 , Inol.; should be addressed to

Prol. Hunter Rouse, State Un1versity ol Iowa, Iowa C1ty, Iowa.

(66) (316) HYDROLOGIC STUDIES - RALSTON CREEK WATERSHED.

(b) Cooperative project, Iowe Inst1tute of Hydraule Research, U. S. Dept. of Agrioulture, U. S. Goolog10al Surrey.

(d) Pruf. J.W. Howe, State Un1verslty of Iowa, Iowa C1ty, Iowa.

(b) Oontinuous records since 1924 of precipltation, runopf, groundwater levels, and cover. Dralnage area thre equare mile ol rolling agricultural land cear east olty $1101 t \mathrm{tg}$ of Iona Clty.

(67) (317) COOPERATIV SURTACE WATER INVESTIGATIONS IN IOWA.

(b) Cooperat1ve projoct betwoen U. S. Coological survey and Iowa Inst1tute of Hydraul10 Research.

(d) Mr. I. C. Crawford or Prof. Hunter house, state University of Iowa, Iowa CIty, Iowa.

(1) Cont1nuous records of stage and discharge of Iowa streams. 
(g) Standard methods on a state-w1de basis.

(h) Gaging stations are maintained cooperatively and on a continuing basis.

(68) (845) STUDY OF HYDROLOGY OF RAPID CREEKS.

(b) Cooperat1ve project, U. S. Geological Survey, U. S. Weather Bureau, and Iowa Inst1tute of Hydraulic Researoh.

(d) Prop. J. W. Howe, State University of Iowa, Iowa C1ty, Iowa.

(f) To secure data for development of rainfall-runoff relations.

(b) Continuous rainfall, ground water, and runoff records since 1941.

(69) (1282) RELATION OF SEDIMENT CHARACTERISTICS TO BED EROSION.

(b) Laboratory project.

(c) E. M. Laursen.

(e) Experimental project.

(1) To evaluate the general relationehip between geometrio and kinemat10 parameters of flow and the mean $81 \mathrm{ze}$ and grading of the bed materlal for an arbitrary condition of scour.

(g) Experiments conducted in glass-valled flume 3 feet deep contalning sluloe gate, apron, depth control at downstream end, and measuring ve1r. Arb1trary geometrioal proportions are kept constant during all runs, the sole varlables beling the rate of flow, the mean diameter and etandard deviation of the sodiment, and the time and depth of scour.

(h) Projeot berely bogun prior to war now being resumed.

(70) (1283) SUPERCRITICAL FLOW IN OPEN-CHANNEL TRANSITIONS.

(b) Laboratory projeot in cooperation with the Commltee on Hydraulic Research, Hydraul108 D101810n, A.S.C.E.

(o) E.-Y. Heu. (e) Analytical and experimental investigation.

(f) To determine princlples of aesign for divergent canal sectlons oarrying high-veloolty plow.

(h) Phases dealing with lateral spreading of unconfined jets and most efflclent boundary flare already completed; Inal phaso of transition from flaring to parallel boundarles now under study.

(1) Graduate theses:

"Characterist108 of superorit1cal llow at an abrupt open-channel enlargement." B. V. Bhoota. Ph. D. Deoember 1942.

Mharacterlatics of superoritical plow at a gradual operi-chennel enlargement." E. $-Y$. Hsu. M.S. February 1946.

(71) FIRE-MONITOR INVESTIGATION.

(b) Bureau of Sh1ps, U. 8. Navy, and U. S. Coast Guard.

(c) J. W. Howe, C. J. Posey, D. E. Metzler.

(e) Experimental for design information.

(P) To Increase the range and concentration of jets from plaed and portable flre mon1 tors.

(g) The effect of the shape of the nozzle alone 18 studied by means of concentration measurements on jets Prom nozzles of different shapes mounted on 2 large approach section designed to reduce the turbulence of the oncoming plow. New forms of plxed and portable monltors have been constructed davIng large sectlons, miter bends, and vanes to reduce turbulence. The conoentrations of the jets from nozzles and monitors are measured by a sampling device at a polnt 90 leet from the nozzle; these results are plotted in the form of contours of equal concentrations from which ourve of peroent of nozzle discharge versus area of jet are drawn. Jet ranges are compared by outdoor photographs from a plxed camera location.

(h) To bo completed by June 2947. 
(72) ELECTRIC ANALOGY OF FLUID FLOW.

(b) In part a laboratory project and in part for the Dav1d Taylor Model Basin, Bureau of Bhlps, U. S. Navy.

(c) P. G. Hubbard, M. M. Hassan.

(e) Experimental investigation.

(1) To study the applicablilty of the nethod of electric analogy to the determination of pressure around bodles of revolution and along contraction nozzles.

(g) Luclte models of varlous boundary forms are proplded H1th sultable contacts and mounted in a copper sulphate bath. With sultable ingtrumentation the voltage drop between successive contacts is determined, and used as a besls for computing the velocity and pressure diatributions along the boundary. Extreme preclsion 18 required, so that accurate results are difflcult to obtaln; bowever, for falred boundarles the analogy 18 good and the indsoated. trends are reliable.

(h) Measurements have been made on hemlspherlcal and elongatad ellipso1dal head forms with oylindrical after bodies, and tests of nozzle forms have begun.

(73) MEASUREMENT OF TURBULENCE IN FLOWING WATER.

(b) David Taylor Model Basin. Bureau of Shlps, U. S. Nary.

(c) M. C. Boyer, B. G. Hubbard.

(e) Experimental projeot.

(1) To develop practical instruments for the measurement of turbulence in plow ing water.

(g) Both the electromagnetic and the hot-wire thods are belng studed xper1mentally w1th the goal of deviaing an instrument which will indeate instantaneous and root-mean-square magnitudes of all three velocity components.

(b) Project is three montho under way.

(1) See Projeot No. 175, Dav1d Taylor Model Basin.

(74) DESIGN AND PROCUREMENT OF HYDRAULIC LABORATORY EQUIPMEAT?.

(b) National Un1versity of Colombla at Bogota.

(c) Inst1tute stafl.

(e) Dontract project.

(1) Provision of up-to-date equipment for student instruction in slud motion and applied research in hydraculis engineoring.

(g) Preliminary design called for three-etory bulling 50 by 100 feet 1n plan: basemant to house reservolr and msasuring basin, basfe machinery and ehops; P1rst Ploor to contain student laboratory, with 15 spsolal itoms of pluidmechenlcs equipment; second Iloor to proplde research gpace, w1th tow1ng tank, glase-wajled channel, and riveromodel basin; thixd Ploor to includo constant-level tank, ofploes, and olassrooms. After approval by Natlonal UnIversity, detalled dosign of all equipwent was made, Pollowed by arrangement of contracts for its fabrication and prosurement.

(b) All equipment has been designed, blds have beon let, and bu1lding is partially completed.

(75) DIFGUSION OF SUBMERGED JETS.

(b) Laboratory project.

(c) M. L. Albartson, R. A. Jensen, Y, -B. DQ1, D. E. Metelor。

(e) Experimental project.

(i) To provide Information as to diatribution of voloolty and turbulence in two- and three-dimensional submerged jeta.

(g) In Inlital phes, weloclty distribution was noasured in als es punotion of longltudinal and lateral position, veloolty of spelux, and size or outlet.

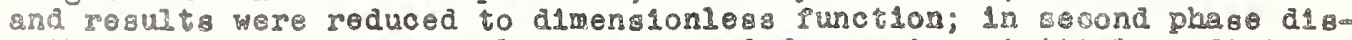
tribition of turbulonos w11 bo measured for various 1 ritial conditions.

(b) Inltial phose now complete and bolng propared for publication. 
(76) GRAVITATIONAL PHENOMENA IN STRATIFIED FLOW.

(b) Laboratory project.

(c) Institute stafr.

(e) Analytioal and experimental projeot.

(f) To provide information as to flow pattern, wave propagation, and diffusion aorose the interface between fluld layers of slightly different speciflo welght due to temperature, salinity, or suspended sediment.

(g) Studies involve generation of sub-surface waves, quant1tative analysis of their celerity and qualitative observation of thelr instab1lity under winddriven surface waves; theoretical and experimental analya1s of the flow pattern corresponding to propagation of an abrupt wave Pront; and exper1mental determination of diffusion across an interface due to artiflolally produced turbulence.

(h) First phase was completed for N.D.R.C. dur1ng war; second phase has just been explored in graduate thesls by Yih; third phase vas begun before war and 18 now being resumed.

(1) Graduate thes18:

"Itudy of the characterlatics of gravity waves at a l1quid interface." C.-8. Y1h. M.S. February 1947.

(77) STUDIES IN EVAPORATION.

(b) Laboratory projeot.

(o) M. L. Albertson.

(e) Experimental, for thesis.

(f) To determine the effect of turbulence upon the transfer of vapor through the boundary layer.

(g) Above a porous poroelain evaporating surface set into a smooth boundary, the veloolty, turbulence, and vapor profiles are measured to determine the thickness of the boundary layer and the laminar sub-layer, and the distribution of diffusivity and vapor immediately above the liquid surface. The velocity and the turbulence are measured by a hot-wlre anemometer, and the vapor ooncentration is determined by very ine wet and dry thermocouples. The Preestream turbulence 18 created by a lattice screen of varlable geometry placed upstream a varlable distance from the evaporating surface. In an accompanyIng study, turbulenoe 18 also created over a free water surface by the rim of an evaporating pan, the pan sizes varying over a wide range of helght, widh, and freeboard rat1os.

(b) In progress.

(1) This study is the experimental continuation indicated in the discussion by M. L. Albertion of paper by G. H. H1ckox, "Evaporation Prom a free water surface", Trans. A.S.C.E., Vol III: 55, 1946.

(78) MODEL STUDY OF SANTA CECILIA PUMPING PLANT INTARE.

(b) Rlo de Janelro Tramway, Light and Power Company, Ltd.

(c) E. M. Laursen, M. R. Carstens. (e) Experimental projeot.

(f) To determine meang of diverting bed load of Paralba River from intake forebay of four $40-\mathrm{m} / 800$ pumpo.

(g) A 1300-meter reach of the Paralba has been built in concrete at a 1:75 undistorted scale. Prevalilng currents and sediment movement w1II be determined, and a sediment-diversion struoture oapable of ready flushing w111 be devised.

(h) River model is oomplete and inftial runs are under way.

(79) CAVITATION.

(b) Dav1d Taylor Model Bas1n, Bureau of Sh1ps, U. S. Navy, and laboratory projeot.

(o) J. S. MeNown, E.-Y. Hsu, C. A. Lamb, A. H. Abul-Fetouh.

(d) Prof. J. S. MoNown, State Un1versity of Iowa, Iowa C1ty, Iowa.

(e) Experimental project supplemented by theoretioal studies. 
(1) To give bas1c design information on presaure distribution around syetemat1cally-varled boundary forme under varlous degress of oavitation.

(g) Tests are conducted in a 13-1nch varlable pressure water tunnel. Measurements are made using $1-1 n c h$ models to determine effect of variation in boundary form, Reynolde number, and degree of oavitation upon the pressure d1atribution around two- and three-dimenslonal boundar1es. The boundary forms to be tested 1nclude the ell1psoldel, conloal, and rounded head forms - Prom elongated to blunt and concave - at var1ous angles of yaw; con1oal and rounded tall forms; and strut and propeller seotlone. A second water tunnel is to be conetructed for the two-dimenelonal forma. Additional teats are belng conducted in a emall water tunnel on the cavitation at gate sloti for var1ous comblnations of slot dimensions and radius of rounding of the downetream edge of the slot, the experiments being compared with olmilar studies in a small alr tunnel.

(h) A bulletin 18 belng prepared describing the preliminary teats and the varlous head forms at zero angle of jaw. The atudy of yaw-angle effoot and design of the water tunnel for essentially two-dimensional flow problems are under way. The experimental work on the study of cavitation at a gate olot 1s partially complete and w1ll be the subject of a ther1s to be complete in June 1947.

(80) TURBULENCE BEHIND SGREENS.

(b) Dav1d Taylor Model Basin, Bureau of Ships, U. S. Navy.

(c) M. L. Albertson, P. G. Hubbard, E. G. Petersen, D. R. Blanoo.

(d)Prof. J. S. Mclown, State Univeralty of Iowa, Iowa C1ty, Iowa.

(e) Experimental project.

(P) To study the energy :08s due to flow through screens and the soale, 1ntensity, and deoay of the resulting turbulence.

(g) screens are formed of bar lattices and of unfformly perforated plates vith syetemat1c variation of acale and area proportions. The pressure drop aoross these screens and soale and Intensity of the turbulenoe at various distances downstream are measured in a low-velooity air tunnel. Three different teohnlques of measuring turbulenoe are used: hot-wire anemometer, heat diffusion, and gas diffusion. A comparison between results in alr and vater 18 planned.

(h) Measurements of pressure drop and turbulenoe have been made for severel soreens of each type. A hot-wire anemometer has been devised shlch reade intensity of turbulence directly, and correlation of the different methods of measurement is in progress.

(1) See Projeot No. 175, Dav1d Taylor Model Basin.

(81) MATHEMATICAL ARALYBIS OF PRESSURE DISTRIBUTION.

(b) Laboratory projeot combined with atudies oonducted for the David Taylor Model Bas1n, Bureau of Sh1pa, U. S. Navy.

(c) J. S. McNown, E.-Y. Hsu, C. S. Y1h.

(d) Prof. J. S. MeNown, State Un1versity of Iowa, Iows C1ty, Iowa.

(e) A theoretical analye18 of llow around varlous boundary forfa.

(1) To advance the application of analytical methode to dealgn prooedure and to obtain information for apeo1f10 problems.

(g) The pressure d1str1but1one around falred boundary forms are obtalned mathemat1cally, assuming that viscous effeots are negl1glble. Both exaot and approxlmate methods are used, and wherever posalble the results are compared w1th experimental measurements determined 1n other etudies. The atudy includes ellipsoldal and hemlspherloal head forms with oylindrloal after bodles, two-dimenslonal wedge shapes with varlous nose angles, twodimenslonal falred itruts, and nozzle forms. The methods of hydrodynam1os, including modifications of the approximate source-sink method presented by von Kármán, are ut1l1zed.

(h) Computations for wodge shapes of varlous angles and representative oomputatlons for several boundary forme bave been completed. A tentative nozzle deslgn 18 partially oomplete. 
(82) HYDRAULICS OF MANIFOLDS.

(b) Laboratory project sponsored by the Committee on Hydraullc Research, Hydraul1c8 Div1s10n, A.S.C.E.

(c) J. S. McNown, J. R. Barton, S. M. Niaz.

(d) Prof. J. S. McNown, State University of Iowa, Iowa C1ty, Iowa.

(e) Experimental studies conducted as theses by graduate students.

(P) To obtain a better understanding of divided and confluent flow, and to provide basic design information for inflow and outflow manifolds.

(g) Tests are conduoted in a 2-1nch smooth brass pipe with a single right-angle lateral to determine the effect of discharge ratio and diameter ratio upon the changes in pressure at the junction, for both alvided and confluent plow. Plezometer connections along the three sections of pipe make possible the determination of the signiflcant pressure changes. The effect of spacing in multiple lateral manifolds, and the pattern of flow and pressurs variation in the 1mmediate violnity of the junction are to be studied.

(b) The study of a single-lateral divlded-flow manifold has been completed and presented in thesis form and the study of confluent flow is under way.

(1) The paper, "Lock manifold experlments" by Edward Soucek and E. W. Zelnick, Trans. A.S.C.E. 1945: 1357, conta1ns a slmilar study applied speciflcally to look manifold design.

A partial summary of the experimental work is contained in the following graduate thesis:

"A study of diverging flow in pipe I1nes." J. R. Barton. M.S. August 1946.

(83) DETERMINATION OF PRESSURE DISTRIBUTION CAUSED BY FLOW OF AIR OVER A SERIES OF TWO-DIMENSIONAL ROOF FORMS.

(b) Laboratory projeot.

(c) G. A. Austin.

(d) Prof. J.W. Howe, State University of Iowa, Iowa City, Iowa.

(e) Experimental, for thesis.

(1) To determine pressure distribution on roofs of varlous slopes.

(g) Experiments in small air tunnel; maximum wind veloo1tios approximately 70 Ips; models about 3 inches in helght.

(h) In progress: complet1on expeoted June 1947.

(84) RELATION OF PITOT-TUBE PROPORTIONS TO VELOCITY INDICATION IN WATER JET3.

(b) Laboratory project.

(c) Y. C. Shen.

(d) Prof. J. W. Howe, State University of Iowa, Iowa City, Iowa.

(e) Experimental for the

(5) Determination of errors inherent in P1tot tube used to measure discharge of vater jete in air.

(g) Effect of 128 of tube in relation to apparent velocity distribution result1ng from traverse of a jet 1s studied. Three sizes of tubes used, 0.03 , 0.06 , and 0.12 inch inside diameter.

(h) In progress.

(85) SYNTHESIS OF THE FLOOD HYDROGRAPH ON RALSTON CREEK, IOWA.

$\begin{array}{ll}\text { (b) Laboratory project. } & \text { (c) M. R. Carstens. }\end{array}$

(d) Prof. J. W. Howe, State University of Iowa, Iowa C1ty, Iowa.

(e) Theoretical, for thesis.

(f) Dotermination of elements of rainfall contributing to runosf in selected storms on Ralston Creek.

(g) Runoff divided according to distance of contributing area from control, assumptions made as to rates of travel and storage, integration of various elements of flow mede to produce synthet1c hydrograph which is compared with actual hydrograph.

(b) In progress. 
(86) UNSTEADY FLOW PROBLEMS FROM MASSAU'S LINE OF ATTACK.
(b) Laboratory project.
(o) P.-H. Lin.

(d) Prop. C.J. Poвey, State University of Iowa, Iowa C1ty, Iowa.

(e) Theoretioal, for Master's thesis.

(f) To develop a step method for computing unsteady flow problems, taking into account the theoretical considerations polnted out by J. Massau.

(g) A computation method w1ll be devised and tested on actual problems in comparison with methode given by Thomas and others.

(b) In progress.

(87) VORTEX OVER OUTLET.

(b) Laboratory project. (o) H.-C. Hau.

(d) Prop. C. J. Posey, State University of Iowa, Iowa C1ty, Iowa.

(e) Experimental, for Master's thesis.

(1) To 1nitlate study of the effect of the vortexes that form over outlets in docreasing the discharge through the outlet.

(g) Water w1ll be introduced tangentlally and radially, in controlled proportions, Into a 6-10ot diameter tanik having a 4-inch standard oriflce at the center of 1 ts smooth level bottom. Heads can be varled up to about 2 feet.

(h) Apparatus designed and being bullt.

(1) Only known previous work 18 the application suggested by J. C. Stevens, and described in C1v11 Englneering, August 1945: 358.

(88) A LENGTH CRITERION FOR THE HIDRAULIC JUR.

$\begin{array}{ll}\text { (b) Laboratory project. } & \text { (c) B. Behera, A. A. Qureshy. }\end{array}$

(d) Prof. C. J. Posey, State University of Iowa, Iowa C1ty, Iowa.

(o) Experimental, for Master's thesis.

(1) To develop a criterion for the length of the hydraulic gump that is closely related to bottom scour, but easy to perform, and which will give results that are not muoh affected by the judgment of the observer.

(g) Tests of Jumps in the one-foot and three-foot plumes of the Iowa Institute of Hydraul1c Researoh, with the potential scour intensity indicated by the point where right olrcular oylinders of different densities, placed on the horlzontal ploor of the plume, will just topple.

(h) Preliminary teats based on toppling of small brass cylinders with lead cores or different radil have been complated, and thesis written. Difficulty encountered in lack of range of higher speolfic gravities of oylinders. Further tests planned for appendix to thesis.

Graduate thes1s: "A length criterion for the hgdraulio jump." B. Behera and A. A. Qureshy. M.9. February 1947.

(194) A STUDY OF METHODS USED IN MEASUREMENT AND ANALYSIS OF SEDIMENT LOADS IN STREAMS.

Report on thls cooperat1ve project glven under Project No. 194, War Department, Corps of Englneers, 8t. Paul Dietriot.

LEHIGH UNIVERSITY, Department of Civ1l Engineering, Bethlehem, Pa.

Inquiries conoerning Projects No. 89 to 92 , 1ncl., should be addressed to Mr. Fale sutherland, D1rector, Fritz Englneerling Laboratory, Lehigh University, Bethlehem, $\mathrm{Pa}$.

(89) CROSS-OVER RESEARCH ON MULTI-8TAGE CENTRIEUGAL PUMPS.

(b) Ingersoll-Rand Company. (c) W. F. H1ltner.

(e) Experimental tests for design purposes. 
(f) To inorease pump efflolenoy, obtain design data.

(8) Efflolency 18 measured and compared for pumps with varlous types of crossovers.

(h) Testing is in progress.

(90) STUDIES OF PRESSURE VARIATION CAUSED BY BOUNDARY MISALIGNMENT IN THEIR RELATION TO CAVITATION IN HYDRAULIC STRUCTURES.

(b) A.S.C.E. Sub-comittee on Cavitation.

(o) W. F. Hiltner, R. E. Crispen, D. W. Appel.

(e) Experimental determination of pressure variation as function of velocity, veloolty head, Reynolds number, Froude number. Correlation and checking of what theoretical aspects may be discovered.

(1) To indicate misalignment tolerance in inspection of hydraulio structures.

(g) Pressure is measured in bottom of open obannel which has varlous transverse steps. Veloc1ty, depth, s1ze, and shape of steps are varled.

(h) Progress report to sub-committee, January 16, 1946.

(91) EFFECT OF REMOVING BOUNDARY LAYER ON DRAG OF CIRCULAR CYLINDER.

$\begin{array}{ll}\text { (b) Laboratory project. } & \text { (c) D. W. Appel. }\end{array}$

(e) Experimental data for general information; student thesis.

(f) To explore effeots of removal of boundary layer upon coeffelent of drag in submerged llow.

(g) Experiments performed with water in open ohannel w1th oylinder parallel to surface. Measure drag and 1ts varlation with changing Reynolds number, quantity sucked away, and attitude of slots relative to the flow. Cylinder I-Inch dimeter by 7.5 inches length. End effects probably serlous.

(b) Tests in progress.

(92) FRICTION FACTOR FOR COAL SUSPENSION.

(b) Laboratory project.

(c) Amnuay Phoonphsphutana.

(e) Experimental data for design of pipes and pump for transportation of coal suspension; student thesis.

(f) Measure friction factor for stralght length of horlzontal pipe carrying suspension of screened coal of unfform $812 \theta, 28$ function of coal concentration, settling velocity, and Reynolds number.

(8) Celibrated pipe is inserted into flov olrcult for screening tests for coal. Head 1088 is measured with differentiel manometer. Rate of discharge and sampling of concentration obtalned from small seotion of total flow.

(h) Tests in progress.

MASSACHUSETTS INSTITUTE OF TECHNOLOGY, Department of Mechanical Engineering, Cambr1dge 39, Mas8.

(93) RECOVERY FACTORS IN WATER.

(b) Laboratory project, for thes18. (c) Professors Keenan and Kaye.

(d) Prof. Joseph H. Keenan, Room 1-202, Mass. Inst1tute of Technology, Cambridge 39, Mass.

(e) Experimental work on flow of water at different temperatures through a tube of circular cros8-section.

(1) To study experimentally the effect of Prandt number on the recovery factor.

(g) Water at varlous temperatures flows through a clroular tube. The surface temperature of the tube was measured and the mean temperature of the water was calculated from the moasured pressure distrlb ion. Recovery factors could then be compared with the palues predioted tneoretioally.

(h) The experimental work has been completed and a paper w1ll be prepared at some later date. 
34 M. I. T.

(94) FLOW OF METASTABLE WATER THROUGH NOZZLES AND ORIFIOES.

(b) Laboratory project.

(o) Profeneors Keenan and Kaye.

(d) Prof. Joseph H. Keenan, Room 1-202, Mass. Inst1tute of Technology, Cambr1dge 39, Mas6.

(e) Experimental 1nvestigation of metertability of l1quid water.

(1) To study the region of metastablilty of l1quid water a 1 t plowe through a nozzle or orlplee.

(8) Hot 11qu1d water at pressures somewhat greater than saturation pressure was allowed to flow through a nozzle or or1f1ce. The rate of flow of the water, the temperature and pressure before the nozzle, and the pressure after the nozzles were measured. The measured flow was compared w1th the theoretioal flow for 18entroplc expaneion. From these data 1t vas planned to determine the limit of the metastability of the 11quid water.

(h) Experimental data have been obtalned.

(95) HYDRAULIC ANALOGUE TO FLOW OF A COMPRESSIBLE GAS.

(b) Bureau of Ordnanoe, U. S. Navy Dept. (c) Prof. A. H. Shap1ro.

(d) Prof. A. H. Shap1ro, Mase. Inst1tute of Technology, Cambridge 39, Mase.

(e) Primar1ly experimental, but w1th eooondary purpose of verlfylng theoret10al concepts. Now being carrled on in form of student theser.

(f) To derive information on the high-speed flow of gases from measurements on water flowing in a channel with a free surface.

(h) In early etages, with no definite results as yet.

(96) MEASUREMENT OF FRICTION COEFFICIENTS NEAR THE ENTRANCE OF PIPES.

(b) National Adv16ory Committee for Aeronaut1c8. $\quad$ (c) Prof. A. H. Shap1ro.

(d) Prof. A. H. Shap1ro, Mas8. Inst1tute of Technology, Cambridge 39, Mag8.

(e) Experimental projeot.

(f) To measure friction ooefflolents in the entrance region of a plpe, where the velocity proflle 1 e changing, and to determine the effeot of Reynolds number and of turbulence.

(h) Some preliminary resulte obtalned whlch ind1oete a qualitat1ve blmilarity to the Plow over a Plat plate for a short distanoe from the entranoo. Friction coefflclente near entrance found to be much higher than in region of atable velocity profile.

UNIVERSITY OF MICHIGAN, Department of C1v1l Englneer1ng, Ann Arbor, M1ch.

(97) BEACH EROSION CONTROL.

(b) Mlchizan Department of Conservation. (c) E. F. Brater, J. D. Caupleld.

(d) C. O. W1eler, 322 W. Englneering Bldg., Un1versity of Miohlgan, Ann Arbor, Mich.

(e) Experimental project.

(f) To determine the most economioal and practical method of shore protection.

(g) In a large wave tank, otudies w11l be conducted to determine the relat1ve effectiveness of varlous types of revetments, open and submerged grolns, and perhap other methods that may be employed for the prevention of beach eros1on.

(h) To be started July 1, 1947.

(1) Th1s w1ll be the f1rst project to be started in the new Lake Hydraul108 Laboratory. As a prelininary, a oareful investigation 18 being made to determine the nature, extent, and results obtalned from previous researches in thle fleld. Th1s preliminary atudy will be completed before any model studies are otarted. At that time, it 18 planned to 18 sue a bulletin glving a blbliography of work that has been and 18 now being done in this fleld, and al60 a etetement of the cbjectives whloh $1 \mathrm{t}$ 18 hoped to aooomplish. 
UNIVERSTY OF MINNESOTA, 8t. Anthony Falls Hydraul10 Laboratory, Minneapol1s 14, Minn.

Inquirles concerning Projects No. 98 to 110, 1ncl., should be addressed to Dr. Lorenz G. Straub, Director, St. Anthony Falls Hydraul1o Laboratory, M1nneapol1s 14, M1nn. Inquir18s conoerning Projects No. 111 to 114, Incl., should be addressed to Mr. Fred W. Blalsdell, Boll Conservation Berv10e, 8t. Anthony Falls Hydraulic Laboratory, Minneapol1s 14, MInn.

(98) FLOW OF SUSPENDED SOLIDS IN PIPES.

$\begin{array}{ll}\text { (b) Standard } 011 \text { Company of Indiana. } & \text { (o) H. D. Purdy, Jr. }\end{array}$

(e) Research under the Standard 011 Company (Indlana) Fellowsh1p Award.

(f) To study the effect of $812 e$ of suspended matter and v1scosity of fluld in llow of suspended solids in plpes.

(b) Just begun.

(99) HYURAULICS OF CULVERTS.

(b) MInnesota Department of Highways in cooperation with U. S. Public Roads Administration.

(c) L. G. Straub, W. W. DeLapp, C. L. Larson.

(e) Experimental investigation for general information on highway culverts.

(f) To develop practical 1nlets and outlets for culverts whlch w1ll be more efflclent hydraulically than those in present use.

(g) Model studies w111 be made of varlous slze culvertg with different lengths and slopes under all possible llow conditlons, using a wide varlety of inlets and outlets. Large scale tests will be made of commerclal types and of types shown superior by the model tests.

(h) Apparatus in initial stages of construction.

(100) HIGH VELOCITY FLOW IN OPEN CHANNELS.

(b) In cooperation w1th the Committee on Hydraul1c Research, A.S.C.E.

(c) L. G. Straub, W. W. DeLapp.

(e) General research and Ph. D. thes1s, experimental study.

(f) To measure the emount of alr entralned in water flowing at high veloclties and 1 ts effects on reslstance coefliclents.

(g) Observations have been made in a channel l-loot wide and 40 feet long, w1th slopes up to $44^{\circ}$ and thres types of boundary roughness.

(b) Report in preparation.

(101) LONGITUDINAL VELOCITY DISTRIBUTION IN A TRIANGULAR CHANNEL.

(b) Master's thesis, University of Minnesota.

(c) H. D. Purdy, Jr.

(e) Experimental and analytical student thes1s.

(P) To determine long1tudinal velocity distribution in a triangular channel.

(g) To determine long1tudinal velocity distribution in a 6-1noh, $90^{\circ}$ triangular open channel, using kerosene as a flu1d. Experiments are conducted in both the laminar and turbulent range using a Pltot tube. Results will be correlated with modern conoepts of flow.

(b) Nearing completion.

(102) VELOCITY DISTRIBUTION AND BOUNDARY SHEAR IN OPEN CHANNELS.

(b) Master's thesis, University of Minnesota.

(c) J. S. Holdhusen.

(e) Experimental and analytical.

(f) To determine the effect of boundary shear on velocity distribution.

(g) Veloc1ty patterns w1ll be determined over discharge area of a rectangular steel channel 3 feet wide and 15 inches deep at slopes greater and less than crit1cal. Boundary shear distribution w11l be determined by the Kármán theory of turbulence.

(h) Experiments are about to begin. 
(103) EXPERIMENTAL AND ANALYTICAL STUDIES OF THE MECHANICS OF MOVEMENT OF SEDIMENTATION ALONG STREAM BEDS.

(b) The Engineering Foundation in oooperation with the A.S.C.E..

(c) L. G. Straub, L. W. Neubauer.

(e) An experimental and analytical study of pundamental nature.

(1) To expand earlier studies of mechanios of bed sediment movement with partioular empheis on the influence of the mechanical properties of the fluid.

(g) A recirculating bystem involving temperature control apparatus, sediment supply system, sediment trap and a test section, of 12 inches width, 24 inches depth, and 42 feet length w1ll be tested with a variety of plulds and sediments over a wide temperature rango.

(h) Planning stage.

(104) FLOW DIVERSION RESEARCH.

(b) David Taylor Model Basin, U. S. Navy Dopt.

(c) A. G. Anderson, E. Silberman.

(e) General thooretical and experimental research.

( $\rho)$ To analyze, 1ntegrate and extend the present knowledge of fundamental meohanics of diverting Pluid Plow streams with special emphasis on the use of guide vane systems.

(g) American and forelgn literature w1ll be coliected, translated, abstracted, and sumarlzed. Sumary will determine extent of theoretical and expeximental studies to be pursued. Pllot studies of general techniques and methods of plow delineation to be oarried on in parallel with literature search.

(h) Blbliography and sumary report nearing completion. P1lot otudies are well under way.

(105) WATER TUNNEL DESIGN STUDIES.

(b) David Taylor Model Barin, U. S. Navy Dept.

(c) J.F. Ripken, L. G. Straub. (e) Experimental oheck of design.

(f) To determine and improve design characteristlce of a proposed 60-1noh diameter, olosed jet, high speed cavitation or water tunnel.

(g) A 1:10 scale model (6-1nch jet diameter) constructed of metal w1ll be tested to determine flow characterlstics, design depiciencies, and operating technqques necessary to the procurement and use of the proposed prototype tunnel.

(h) Model tunnel under construction.

(1) See Project No. 175, David Taylor Model Babin.

(106) INVESTIGATION OF A MODEL SEDIMENTATION BASIN.

(b) Master'a thesis, University of Minnesota.

(c) B. K. Banerjee.

(e) Experimental Investigation.

(f) To determine the governing model law and efficiency of operation of a sedimentation basin.

(g) Determine the distribution and bizes of sediment deposited in various parts of the basin for different conditions of operation. Glas spheres from 10 to 60 microns in alameter w11l be used for sediment.

(h) Experiments are about to begin.

(107) CHIPPEWA RESERYOIR SPILLWAY MODH.

(b) Northern States Power Company.

(c) L. G. Straub, W. W. DeLapp.

(e) Experimental model study.

(f) To establish optimum design of changes in exlsting structure for the purpoвe of decreasing downstream erosion. 
(g) Flow and erosion patterns studied for varlous designs in a three-dimensional model constructed to a scale of 1:24 for a complete range of discharges.

(b) Near completion.

(108) LARGE SCALE CULVERT STUDIES.

(b) American Concrete Pipe Assn.

(c) L. G. Straub.

(e) Experimental study of hydraul1cs of commerclal culvert types.

(P) To establish entrance $108 s e s$ and plpe priction losses in culverts flowing at varlous capac1ties and heads, full and partly full.

(g) 24-1nch culverts, 200 feet long, are constructed successively into the main testing channel of the St. Anthony Falls Laboratory and observations are made of head losses for varlous rates of discharge.

(h) Experiments have been begun on a 24-1nch concrete culvert, 200 feet long, set at a slope of 0.2 percent.

(109) MODEL STUDY OF THE DESIGN OF A WATER SOFTENING TANK.

(b) Standara 011 Company of Indiana.

(c) L. G. Straub, J. E. Fant.

(e) Commercial research.

(p) To determine the most epflcient design and location of an inner efpluent cone in a gravity system settling tank.

(g) Tests made using glass spheres ( 12 to 60 microns in diameter) and determinIng results quantitatively as to the efficiency of the tank.

(h) Report in preparation.

(110) EFFECT OF VISCOUS FORCES ON EFFICIENCY OF WATER SOFTENING TANK.

(b) Master's thesis, University of Minnesota.

(c) J. E. Fant.

(e) Master's thesis.

(P) To determine in a model of a settling tank the influence of $\nabla 18 c 0 u s$ porces on turbulence and efficlency by using ldealized glass spheres as sediment.

(g) Tests to be made la a model with results as to the efficiency to be determined quantitatively and qualitatively from samples of the epfluent.

(h) Equipment completed.

(111) DROP INLET CULVERT WITH PIPE CONDUIT.

(b) Divigion of Drainage and Water Control, Soll Conservation Service, U. S. Dept. of Agriculture, in cooperation with Minnesota Agrioultural Experiment Station.

(c) S. H. Anderson, F. W. Bla1sdell. (e) For design purposes.

(1) To obtain data on the hydraulic performance, discharge, and pressures.

(g) The tests w1ll cover the complete range of conaltione encountered in the fleld. Data will be obtained for several types of drop inlet and for pipes laid on both steep and flat slopes. Results will be reduced to the simplest possible form. Tests are in progress. Some results have been obtalned.

(h) study in progress.

(1) The plpe drop Inlet culverts la1d on steep slopes (I on 3) plow completely full when the outlet discharges freely.

"Preliminary results of tests on plpe bleeders lald on steep slopes." Fred W. Bla1sdell. November 1942. This publication is avallable for loan by writing to the Project Bupervisor, Soll Conservation Service, St. Anthony Falls Hydraulic Laboratory, Minneapolis 14, Minn.

(112) DROP SPILLWAY WITH BOX INLET.

(b) Division of Drainage and Water Control, Soll Conservation Service, U. S. Dept. of Agriculture, in cooperation with Minnesota Agricultural Experiment Station.

(c) F.W. Blalsdell, C. A. Donnelly. (e) To dovelop a generallzed design. 
(f) To obtain disoharge coefflolents and other information required for the design of bor Inlet drop splllways.

(g) Experiments are run on models to determine the effect of different length to w1dth rat108, helght of drop, channel width, dike location, oubmergence, etc., on the discharge curves.

(h) Some reaults have been obtalned. Tests are now under way.

(1) Hhe hydraul1e design of rectangular sp1llways." Albert N. Huff. October 1943. Th1s publication 1s avallable for loan by writing to the Project Superv1sor, Soll Conservation Serv10e, St. Anthony Fallo Hydraul10 Laboratory, Minneapol18 14, Minn.

(113) OUTLET FOR BOX INLET DROP SPILLWAY.

(b) D1v181on of Dralnage and Water Control, Soll Conservation service, U. S. Dept. of Agriculture, in cooperation with MInnesota Agrioultural Experiment Station.

(c) C. A. Donnelly.

(e) To develop a general1zed des1gn.

(1) To develop a sat1sfactory outlet structure for box inlet drop splllways.

(g) The design w1ll be general and dimensionless so that the outlet can bo applied to any s1ze of box Inlet drop splliway or any discharge. Emplrioal methode were used to develop the outlet.

(b) study completed; report beling prepared.

(114) DIVERGING TRANSITIONS FOR SUPERCRITICAL VELOCITIES.

(b) Div181on of Dralnage and Water Control, Soll Conservation Service, U. S. Dept. of Agriculture, in cooperation with Minnesota Agricultural Experiment station.

(c) F. W. Bla1sdell.

(e) To obtaln data for design purposes.

(f) To provide data for the design of transitions where the velooity is greater than the critical.

(g) Study w1ll cover transitions for use in the approach to the St. Anthony Fallo st1lling basin. Surface contours are determined for different Froude numbers, shapes of entering stream, sldewall plares, bed slopes, eto.

(b) study under way. Progress report on tests to dete 1s beling prepared.

(1) Studies to date give surface conflguration for one floor slope and one in $3 \sqrt{ }$ s ldewall divergenoe for Froude numbers from 1 to 16.

(115) CORRUGATED PIPE DROP INLET CULVERTS.

(b) Minnesota Department of Conservation, D1v1s1or of Water Resouroes and Engineerlng; Division of Drainage and Water Control, Soll Conservation Servioe, U. S. Dept. of Agriculture; Northwestern D1v181on, Armco Dra1nago and Metal Projeots, Ino.; Minnesota Agricultural Experiment station.

(c) A. W. Sturman.

(e) To obtain design information.

(d) Halter S. Olson, Director, Div1sion of Water Resources and Englneering, Minnesota Department of Conservation, st. Paul, Minn.

(f) To obtain information on the hydraul1cs of the structure, to obtaln headdischarge curver for the inlet, to develop an energy disalpator, and to study flow conditions in the downstream ohannel.

(g) Thls structure 1s to be used as a drop structure for dra1nage ditches and h1ghway culverts. Tests are belng conducted on corrugated Luolte plpe and movable bed ohannels.

(h) Experiments are progressing slowly due to the 1nability of personnel to dovote full time to the study. 
THE UNIVERSITY OF MISSOURI, sohool of Mines and Metallurgy, Rolla, Mo.

Inquirles concerning Projects No. 116 and 117 should be addressed to Prof. Joe B. Butler, School of Mines and Metallurgy, Un1versity of M1seour1, Rolla, Mo.

(116) FLOW THROUGH SMALL LOW HEAD SYPHONS.
(b) Laboratory project.
(c) J. B. Butler, E. R. Broadbent, E. A. We1nel.

(e) For general information.

(f) To note discharge, Priction 1088 , and peak suctions in syphons made of rubber hose, smooth bent 1ron, lead and brase p1pes, welded jo1nt p1pes, plpes connected w1 th common sorew-end plpe elbows and in deviated plow around common ocrew-end Tees under low heads varying prom 4 to 0 peet. Later in project, plaring outlets and changing of pipe o1zes throughout the length of the eyphons w1ll be introduced.

(g) The primary purpose w1Il be por student demonetrations in hydraulice to demonstrate priction and suction elpects. If a more thorough search of hydraulic ilterature showe a substantial part of this projoct to involve new research, the results 80 obtained w1ll be prepared for publication.

(h) Largely qual1tat1ve and observational w1th garden hose and sorew-end jolnted plpe used in student demonatration with outlet heads varying from 3 to 0 seet.

(1) Present references are short etatements from hydraul1cs text. Currently searcher will be made 1nto the pull pleld of published literature so that more of the search can go into flelds not covered by experiments.

(117) STUDY OF GUCTION IN TUBES AND BMALL HYDRAULIC APPLIANCES ESPECIALLY AS LIMITED OR AFFECTED BY ADHESION AND COHESION OF AIR AND WATER.

(b) Laboratory project. (c) J. B. Butler, E. W. Carlton, V. A. C. Gevecker.

(e) For general information.

(f) To note actual auction values where the application of Bernoullis theorum Indicates spec1f1c values, and to crowd each device to where the tendency to flow full through action of adhesion and cohesion of water is cancelled against limiting suction values.

(g) The primary purpose w1ll be for student demonetration in large hydraulic classes. As an extension of the search of hydraulic literature shows where a substantial part of this project as expanded can involve new research, the results so obtained will be prepared for publication.

(h) Largely qualitative and observational to start with, as showing students the limits where auction devices break down tendency por full plow at exit.

(1) Present references are short statements from hydraulic texts. Currently searches w1ll be made into the pull fleld of published literature so that more of the search can go into plelds not covered by experiments.

NEWPORT NEWS SHIPBUILDING AND DRY DOCK COMPANY, Newport News, Va.

Inquirles concerning Projeots No. 118 to 124, Inclusive, should be addressed to Mr. C. H. Hancock, Hydraul1c Laboratory and Sh1p Model Testing Basin,

Newport News Bhlpbullding and Dry Dock Company, Newport News, Va.

(118) CONDENSER SCOOP DRAG TESTS.
(b) Laboratory project.
(c) W. F. Taylor.
(e) Experimental.

(f) To obtain the additional drag resiatance on a sip due to the condenser scoop appondages.

(g) scoops to be Installed in the bottom of a float in the open test section of a c1rculat1ng water channel. A aultable boundary layer to be created by roughening the surface. Measurements of the induced flow in the scoop and the 1ncreased drag on the lloat to be obta1ned.

(a) Awalting completion of clrculating water channel apparatus. 
(119) FLUID FLOW BY BENTONITE METHOD.

$\begin{array}{ll}\text { (b) Laboratory project. } & \text { (c) J. F. Snyder, W. F. Taylor. }\end{array}$

(e) Experimental data.

(1) To investigate and calibrate the Bentonite method of visualizing fluid flow.

(g) Observe, through a polariscope, the streaming double refraction, of a Bentonite suspension. Study the grades of Bentonite, methods of making and relining the suspension, and work up polariscope, model-making and testing procedure. Callbrate the flow so that the method may be used in our fluld llow problems.

(h) Unfinished.

(1) Detalls of method may be found in W1sual studies of fluid flow patterns resulting from streaming double refraction by Davis $R$. Dewey, II, Doctor of Sclence thes1s, Dept. of Chemical Englneering, Massachusetts Inst1tute of Technology, 1941 .

\section{(120) RUDDER TESTS.}

(b) Hull Technical Division, Newport News Shipbullding and Dry Dock Company.

(c) W. F. Taylor, B. R. Lee. (e) Experimental, design data.

(1) To obtain moment and lipt on ships' rudders for design data.

(g) Test ships rudders in a clrculating water channel.

(h) Unfinished; walting completion of circulating water channel.

(12I) ANGULAR MOTION OF SHIPS IN WAVES.

(b) Hull Technical Division, Newport News Shlpbuilding and Dry Dock Company.

(c) H. F. Taylor. (e) Experimental investigation of theoretioal question.

(I) To determine if a ship in a quartering sea rolls and pltches at 1 ts so-called natural perlods, or $1 \mathrm{f}$ it assumes some angular motion, not true rolling or pitching, but a combination of the two, having some period between the so-called natural perlods of rolling or pitching.

(g) A model was ballasted to exaggerate the difference between the natural perlod of rolling and pitching and then moored in the 56-poot model basin through glmbals, allowing rolling and pitching, and a paraliel motion linkage, allowling heaving, but not restraining yaw and lateral oscillation. The model at varlous headings was subjected to waves of varlous lengths. Data Irom a chronograph were recorded as perlod of waves vo period of roll1ng, pltching, or heaving for each heading. Because the preliminary apparatus lacked stilfness, and restrained longltudinal and transverse oscillation and recorded only period and not amplitude, 1t was decided to redesign the apparatus and repeat the test.

(h) The redesigned apparatus has been completed and tested, but the results have not been analyzed.

(122) CAVITATION TURBINE TESTS.

(b) Hydraulic Division, Newport News Shlpbuilding and Dry Dock Company.

(c) B. R. Lee, K. S. Black, W. C. Madison.

(e) Experimental for design data on hydraulic turbines.

(f) To determine critical sigma of various designs.

(g) Scale model turblnes are tested at constant speeds and varying suction heads to determine sigma at which the efflciency and head curves arop. Latest test was made in connection w1th Russian turbines for Dnieprostro1 Dam.

(b) To be continued as required.

(1) New apparatus being installed which w1ll enable higher suction heads and consequentiy lower sigmes.

(123) REGULAR TURBINE TESTS.

(b) Hydraul1c Division, Newport News Shipbuilding and Dry Dock Company.

(c) B. R. Loe, K. S. Black, W. C. Madison. 
(e) Experimental for design data on hydraulic turbines.

(P) To determine power and efflciency curves for various unit speeds.

(g) Scale model turbines are tested at various unit epeeds and calculations made to determine efflciency and unit horsepower. Recent tests included work on turbine models for Grand Coulee Dam in Washington and Dnieprostrol Dam in Russia.

(h) To be continued as required.

(124) METER CALIBRATION TEST.

(b) Hull Englneers, Newport News Shlpbullding and Dry Dock Company.

(c) B. R. Lee, K. S. Black, W. C. Madison. (e) Production.

(1) Calibrate gasoline or water meters used for testing or about to go aboard ship.

(g) Meters tested at varlous heads and quantities by the usual weighing tank. Time recorded electrically by chronograph.

(h) As required.

UNIVERSITY OF NORTH CAROLINA, North Carolina State College of Agriculture and Engineering, State College Station, Raleigh, N. C.

(125) DYNAMIC STILARITY OF SMALL HYDRAULIC MODELS.

$\begin{array}{ll}\text { (b) Laboratory project. } & \text { (c) N.W. Conner. }\end{array}$

(d) Prof. N. W. Conner, Department of Engineering Research, Univerelty of North Carolina, Raleigh, N. C.

(e) Theoretical research.

(1) To make a theoretical study of dynamic similarity of omall hydraulic models and at large-scale ratios.

(g) The results of the experiments will be coordinated with existing data to form an integrated serles giving a complete plcture of present knowledge.

(b) One paper is in the process of being written.

NORTHWESTERN UNIVERSITY, The Technological Institute, Evanston, IIl.

(126) RESISTANCE OF BARGE FORMS IN SHALLOW WATER AND RESTRICTED CHANNELS.

(b) Laboratory project.

(c) W. S. Hamilton.

(d) W. S. Hamilton, Civil Engineering Department, Northwestern Technological Institute, Evanston, Ill.

(e) Experimental, for Pundamental information.

(f) To determine the resistance coefficients of simple barge forms in terms of the shape and dimensions of the forms relative to the depth and width of the water in which they are towed.

(g) Barge models are towed at constant speed in a tank in which the depth and width are variable. The tow 11 ne and pulleys are ariven by an electric motor; the veloc1ty 18 measured with a spark chronograph, and the towing force with a recording dynamometer carried by the model.

(h) Preliminary testo on the apparatus have been made and a new dynamometer 1s under construction. No results are avallable.

(1) For a description of the towing tank see "A bimple apparatus for measuring the epeed and resistance of hull modelo" by Wallis s. Hamilton, Marine Engineering and Shlpping Rev1ew: 163-166. September 1945. 
(127) RELIEF FROM WATER HAMGER BY MECHANICAL-PNEUMATIC SURGE SUPPRESSOR8.

(b) Laboratory project.

(c) M. B. Gamet, L. H. Keseler.

(d) Prof. M. B. Gamet, Acting Chalrman, C1vil Englneering Dapartment, Northwestern Technological Inst1tute, Evanston, Ill.

(e) Experimental, for design purposes.

(f) To 1ncrease the shook-absorbing capac1ty of meohanical-pneumat10 water hammer arresters by plaoing nitrogen under pressure in the compresilon chamber, at a un1t pressure equal in magnitude to llow pressures encountered in practice. The effective shook-absorbing oapacity is inoreasea with a corresponding reduction in overall size of the surge suppresior rather than having the compresilon ohamber pliled with a gas at atmospheric pressure.

(g) Performanoe 18 analyzed by pressure-time diagrams on water plpe lines upetream Prom the quick closing valve and surge suppressor. Fatigue tests of compresiion ohamber unit are also conducted.

(h) One suppressor 18 under test w1th pressures of nitrogen in compression chamber varying from 5 to 90 pBi. A large suppressor with 300 pBi in compression ohamber is under construction. Two-1nch pipe ilnos supplied by standplpe and centrifugal pump are used at present.

(1) "Rellel from water hammer." Jour. A.W.W.A., Vol. 30, No. 1, January 1938. "Performance of flu1d 1mpact absorbers for water supply plping in bulldings." Merrill B. Gamet. M.S. thes18, Un1versity of W18consin L1brary, 1937.

THE OHIO STATE UNIVERSITY, Department of Kechanloal Englneering, Colubbus 10, Oh10.

(128) A STUDY OF PULSATING FLOW THROUGH INFERENTIAL HEAD METERB.

(b) A.S.M.E. Special Research Committee on Flu1d Meters.

(c) E. J. LIndahl.

(d) S. R. Beltler, Professor of Hydraul10 Englneering, The Oblo 8tate Un1versity, Columbus 10, Oh1o.

(e) Experimental investigation of error in meter-reading caused by pulsating flow through meters.

(f) To determine numerical values of errors and methods of eliminating them.

(g) Or1110e meters have been set up to measure gas and a1r, with arrangements to accurately measure the quantity, with the meter subjeot to pulsating Ilows, and with steady llow. Apparatus has been devised to measure pulsation amplitude and to determine whother a meter 1 s 1naccurate due to pulsat1on. Different methods of eliminating the effects of pulsation bave been tried.

(b) A new laboratory set-up 1s being constructed to study tuned types of eliminators.

(1) The following papers have been published oovering this work: Developments in the measuring of pulsating plows with inferential-head meters." 8. R. Boltler, E. J. Lindahl, and H. B. MoN1ohols. Trans. A.S.M.E., Vol. 65, No. 4: 350-352. May 1943.

"Pulsation and 1 ts effect on flow meters." E. J. Lindahl. Trans. A.8.M.E., Vol. 68 , No. 8: $883-894$. November 1946.

THE PENhSILVANIA BTATE COLLEGE, School of Engineering, state College, Pa.

(129) HATER TUNNEL MODEL STUDIES.

(b) Ordnanco Research Laboratory at The Pennoylvania State College.

(c) J. M. Robertion, D. Rовв, A. M. Feller, W. M. Waohter.

(d) Prop. J. M. Robertson, Hydraul1cB Laboratory, Sohool of Eng1neoring, The Penneylvania State College, State College, Pa. 
(e) An experimental and theoretioal atudy for design purposes.

(f) To develop methods for predicting flow condltions in water tunnel oomponents.

(g) Water tunnel components, w1th diameters one-elghth the proposed prototype dimensions, are belng studied in a model tunnel whlch does not include a model pump. Flow 18 taken from and returned to a sump in a single pase system and 18 measured over a standard reotangular weir. The model test section diameter 186 inches and veloolties up to 50 fps are possible. As the sections are interchangeable, varlous lengths of components, shapes of nozzles, and angles of diffusion and varlous slzed turns may be tested. The components are studied as they are inter-related; thus in the diffuser, to almulate prototype entranoe conditions over a large range of Reynolds numbers, the length of the stralght (or test) section preceding the diffuser 1s varled over wide limita. Experimental resulte are integrated with theoretical methoda, in an attempt to develop means for predicting prototypo Plow conditions for use in design.

(h) Teste are in progress. Sat1sfactory methods appear to have been developed for the nozzle analysis. Test resulte appear to correlate well with modern theory on flow in the stralght (test) section when proper allowance is made for nozle epfects. Diffuser flow analysis has reached the stage where a parametric form of presentation 18 avallable for tunnel design.

(130) WATER-TUNNEL VANED-TURNS STUDIES.

(b) Ordnance Research Laboratory at The Penneylvania state College.

(c) J. M. Robertson, A. I. Turchett1, D. Ross.

(d) Prof. J. M. Robertson, Hydraul1os Laboratory, Sohool of Engineering, The Pennaylvania State College, State College, Pa.

(e) Experimental study for design purposes; also M.S. thesls.

(1) To determine the best oontour and proportions of the turning vanes to be used in the pour turns of the water tunnel.

(g) Studies w1ll be concentrated on the pressures on and flow conditlons after a vane design based on aerodynamic pract1ce. Thla type vane w1ll be tested in two sized turns (10-1nch and 12-1nch diameter) with several different gap-chord rat1os. Tests w1ll be made in model tunnel (see Project No. 129) and will attempt to study the cavitation propensities of the turn under conditions elmulating prototype operation.

(h) Vanes of 1.5-1nch chord are belng fabrlcated.

(131) SHAVER CREEK HYDROLOGIC STUDY.

(b) Cooperative project with U. 8. Weather Bureau and U. S. Forest Bervice.

(c) J.R. Villemonte, J. M. Robertson, W. M. Waohter.

(d) Prof. J. M. Robertion, Hydraulics Laboratory, School of Englneering, The Penneylvania State College, State College, Pa.

(e) Long term study of hydrologic action of a watershed.

(f) To obtain data on rainfall, runof, and evaporation for a small mountain watershed.

(g) The watershed area 18 about 3.8 square m1les. Runoff 18 measured by a callbrated stream control (see project No. 132), ralnfall 1s measured with three recording rain gages, and evaporation from a standard pan.

(b) Measurements are under way, inflial reduction of data 1s continuing.

(1) Th1s project was started in 1941 by F. T. Mav1s (now at Carnegle Institute of Technology) and J.R. V1llemonte (at present on leave).

(132) A NEW TYPE OF STREAM CONTROL.

(b) Laboratory project. (c) J.R. V1llemonte.

(d) Prof. J. M. Robertson, Hydraul1cs Laboratory, School of Englneering, The Pennsylvania State College, State College, Pa.

(e) Experimental projeot.

(f) To develop a new type stream control for stream gaging work. 
(g) Model and prototype studies (soe description of welr in abstract of paper by V1Ilemonte).

(b) At present Inactive due to absence of Prof. Villemonte.

(1) Recent work as an undergraduate thesis was done on a version of this control for smaller flows.

New type gaglng station for small streams." J.R. Villemonte. Englneering News Record 131: 748-750. November 18, 1943.

Based on model and prototype studies, a new type of gaging station for small streams has been developed. The measuring welr is oreated by 1 stalling two triangular-shaped sllis on the floor of a culvert, a amall space between the 811la creating a throat. For large flows, the control shlfts from the sills to the inlet wingwalls of the culvert. A silling p1pe supporting the level recorder 18 installed upstream. RatIng curves and effects of submergence are provided.

(133) WEIR STUDIES.

(b) Laboratory project. (o) J. R. V1llemonte.

(d) Prof. J. M. Robertson, Hydraulics Laboratory, School of Englneer1ng, The Pennsylvania State College, State College, $\mathrm{Pa}$.

(e) Experimental project.

(1) Study of proportional and other welrs and the effect of submergence on the1r disoharge character1st1cs.

(h) Inactive due to absence of Prof. Villemonte.

(1) "Proportional We1r Hork." Englneer1ng Newg Record 132: 461. Apr11 6, 1944. A history of proportional welr work, with a discussion of recent developments.

UNIVERSITY OF PENNSYLVANIA, C1V11 Engineering Department, Ph1ladelphia 4, $8 a^{.}$

(134) EXPLRIMENTS ON VENTURI NETERS OF HERSCHEL TYPE.

(b) Conducted for meter manufacturers and as a laboratory project.

(c) W. S. Pardoe.

(d) Prof. W. S. Pardoe, C1v11 Eng1neer1ng Department, Un1vers1ty of Pennsylvania, Philadelphia 4, $\mathrm{Pa}$.

(e) An experimental investigation.

(1) To determine the effect on the coeffclent of the size and number of throat plezoneter holes, and the condition and shape of the throat plezometer holes.

(g) Experiments conducted on 10-1nch by 5-1nch S1mplex Valve and Meter Company and $8-1$ nch by $4-1$ nch Bullders Iron Founory Ventur1 metere with removable bronze throats. $81 z e$ of holes 1/16-1nch to 1-1nch, number of holes 1 to 6 . Condition of holes, burrs due to drilling, edges square and flusb, countersunk and rounded edges.

(b) About half completed.

(1) This 18 not a duplication of Prof. Allen's work, as the veloolty traverse is flat at the throat of a Ventur1 meter.

PENNSYLVANIA WATER \& POWLR COMPANY, Laxington Bullding, Balt1more 3, Md.

(135) WATER MEASUREMENTS WITH ARTIFICIAL RADIO-ACTIVE MATERIAL3.

(b) Penniylvania Water \& Power Company.

(c) J. E. Allen, S. K. Waldorf, Dean B. Cow1e (consultant).

(d) J. E. Allen, Chief of Tests, Pennsylvania Water \& Power Company, 1611 Lexington Bullding, Balt1more 3, Ma. 
(e) Experimental project.

(f) Teating large hydraulic turbines.

(g) Water measurements by tracer methoda using artificial radio-active 1sotopes w1ll be invest1gated. Methods and apparatus will plrst be developed for precise measurements of wak radio-active solutions. For turbine testing the accuracy of measurement must be a small fraction of one precent. Actual measurements of water will then be made, first volumetrically in a large welghing tank, and second with llowing water in the Holtwood Hydraulic Laboratory. Both Gelger-Muller counters and improved electrometers will be studied to determine the method.most suitable.

(b) Development work on apparatus for measurement of weak solutions is now in progress in the laboratory.

\section{(136) (137) (138)}

The three following studies are closely interrelated in an attempt to derive reliable basic material for further studies on the hydrology of a large river basin. This is done not only for the purpose of current forecasting, but to explore the underlying princlples concerning the pluctuations of rainfall and runoff. After evaluation of ground water, it has been found posalble to develop excelient correlations between the month? r ralnfall and the amount of water whlch w1ll eventually, even if not immediately, appear as runolf. (See graphs p. 636, Journal A.W.W.A., Vol. 37, No. 7, July 1945). These permit constructing a sufficiently close approximation of the mass curve of runoff to extend with considerable confldence the actual mass ourve some twenty-five years prior to the beginning of any stream gauging on the susquehanna River.

\section{(136) REFINEMENT OF FLOW RECORD FOR THE SUBQUEHANNA RIVER.}

(b) Research project.

(c) Office of Special Studies.

(d) Carroll F. Marriam, Penneylvania Water \& Power Company, P. 0. Box 2076, Balt1more 3, Ma.

(e) Statistical analysis and reconciliation of systematic errors in four independent continuous measurements of stream flow.

(p) To maintain the hlghest possible degree of rellability in a long river flow record for eventual use in hydrologic research.

(g) Reduction of original data to comparable form by elimination of known systematic errors, exacting graphic analysis to accentuate accidental errors and final averaging of the four components.

(h) There is now avallable continuous record on uniform basis from 1931 and work is currently carried on. The pact that twelve month totals for each component record taken independently regularly $\rho$ all w1 thin range of 0.7 percent indicates that conslstency in determination of annual runof to order of 0.3 percent is obtained.

(1) On completion of each year's work the results are reported to the U. S. Geological Survey.

(i37) EVALUATION OF GFOUND WATER IN SUSQUEHANNA RIVER.

(b) Research project.

(c) Offlce of special studies.

(d) J. V. Stumpe, Pennsylvania Water \& Power Company, P. 0. Box 2076, Balt1more 3. Ma.

(e) Analysis of data collected by the U. S. Goologleal Survey on ground water levels in Penneylvania and New York and reduction of data to comparable basis to make possible derivation of index plgure representing the average in spite of wiae variations in the speciplc characteristics of individual wells. Reduction of th1s average to quantitative determination of water stored and. eventually to appear as runoff. Determination of resulting ground water hydrograph.

(f) Prediction of assured llow, that 1s, flow whlch could be guaranteed even without further rainfall.

(h) Determination of weekly average now reduced to routine and foreosts of assured flow based upon ground water hydrograph plus surface water flow made currently for two weeks in advance. Constant chooks of unusual naturo made to insure rellability of data. 
(1) Evaluation of ground water has been found to be key to further analysis of operation of hydrologio cyole in the Susquehanna.

"Analysis of natural fluotuations in ground-water elevation." Carroll F. Merrlam. Trans. American Geophysical Union, Pt. II, 1942: 598-603. Amerloan Water Works Assn., Vol. 37, No. 7: 632. July 1945.

(138) DISTRIBUTION OF RAINFALL AND RUNOFF IN THE SUSQUEHANNA VALLEY WITH RESPECT TO AREA AND TIME.

(b) Research project.

(c) Office of Speolal Studies.

(d) Carroll F. Merriam, Penneylvan1a Water \& Power Company, P. 0. Box 2076, Balt1more 3, Ma.

(e) Applioation of statist1cal methods effeotive in forcing the betrayal of observational errors in past records.

(f) To prepare data of sufficlent refinement to be used as basis for hydrologic studies with minimum danger of misleading results. These data are intended to be the most reliable for oyclio analya1s, teste for secular trends, oorrelation w1th other meteorologic data, etc.

(g) Stream gauge recorde and partloularly individual rain gauge records have been shown to be subject to observational errors whlch have in some cases led to serlously mlsleading conclusions.

(h) Attempt 18 made partly by 1 dent1flostion of these errors and partly through welght of number or reoords averaged together to bulld up records whloh wlll be as free as possible from these disturbing defects, and so permit more reliable deductions to be drann regarding nature of fluctuations in water supply and correlations w1 th other contemporary observations.

(1) Consistency of interrelation between runoff and rainfall as determined independently of each other indicates that a considerable degree of sucoess has been obtained.

PRINCRTON UNIVERSITY, Sohool of Englneering, Princeton, New Jersey.

(139) TOHINO TANK RESEARCH.

(b) Dav1d Taylor Model Basin, Navy Dept., and laboratory project.

(c) J. H. Harrison, A. D. Hay, C. P. K1ttredge.

(d) Prof. A. D. Hay, Towlng Tank D1rector, School of Englneering, Princeton Un1versity, Princeton, N. J.

(e) Theoretical and experimental research.

(f) To explore some fundamental researoh in hjareulics hitherto untouched by the larger model basins.

(g) Present work 18 confined to towing simple geometrio forms through the surfaos of water for reslstanoe and wave measurements, and analyzing the relat1ong between regults.

(h) Two reports have been completed and two others are about to be publlshed.

8. MORGAN SMITH COMPANY, YOTk, Pa.

Inquirles conoerning Projects No. 140 to 143, Inol., should be addressed to Mr. George A. Jessop, Chlel Englneer, B. Morgan 8m1th Company, York, Pa.

(140) EFFICIENCY, DISGLARGE, AND CAVITATION TESTS ON ADJUSTABLE BLADE AXIAL RLOW PUMPS.

(b) S. Morgan Smith Companj.

(o) R. Sahle, J. Thorell, and laboratory personnel.

(e) Experimental research.

(f) To determine the discharge, efflolenoy, and oavitation limlts of various blade derlgns. 
(g) Complete pump model was made and 1nstalled in our closed system pump stand. P1 tot tube traverses were made above and below the 1mpeller in order to determine the velocity distribution and angle of flow of water in the suction tube and as the water entered the stationary guide vanes in the discharge tube. Cavitation tests were conducted and the value of sigma determined bJ the usual method. New 1mpeller and guide vanes were designed from th1s data and the tests repeated.

(h) Tests are now in progress.

(141) ADJUSTABLE BLADE SEWAGE PUMP, DISCHARGE, EFFICIENCY AND CAVITATION TESTS.

(b) S. Morgan Sm1th Company.

(c) R. Sahle, J. Thorell, and laboratory personnel. (e) Experimental research.

(1) To determine the discharge, efplclenoy, and cavitation limlts on a special design spiral casing using an adjustable blade 1mpeller.

(g) A complete pump model was made and installed in a closed system pump stand. The pump has no guide vanes in the splral discharge casing or suction bell 1ntake. This type of pump 1s specially designed for sewage pumping. P1tot tube traverses were made above and below the 1mpeller. Alterations in the spiral casing were made and tested.

(h) Tests are now in progress.

(142) FRANCIS TURBINE, EFFICIENCY AND POWER TESTS, ALTERATIONS MADE ON RUNNER DESIGN.

(b) S. Morgan Sm1th Company.

(c) R. Sable and laboratory personnel.

(e) Experimental research.

(f) To obtain additional power and st1ll maintain high efficiency by making alterations to the runner designs.

(g) Investigation was carried out in an open plume and on a vertical draft tubo. P1 tot tube traverses were made at varlous locations in the gate section of the wheel case and also in the draft tube below the runner. The direction of flow and the veloc1ty was measured at each location. These tests were run at several gate openings. New and improved designs w1ll be made from these data and further testing will be done.

(h) Tests are now in progress.

(143) STUDY OF PRESSURE CONDITIONS IN A SPECIAL DESIGN RIGHT-ANGLE ELBOW WITH GUIDE VANES AND SPECIAL DESIGN ROTO-VALVE INSTALLED IN A HIGH VELOCITY PIPE LINE.

(b) Board of Water Supply, C1ty of New York, Kensico Hill V1ew Station.

(c) John Haupt, New York Board of Water Supply; R. Sable and laboratory personnel, S. Norgan Sm1th Company.

(d) Mr. F. G. Sw1tzer, New York Board of Water Supply, New York, N. Y.; or Mr. George A. Jessop, Chlef Englneer, S. Morgan Smlth Company, York, Pa.

(e) Experimental research.

(1) The object of these tests 18 to determine, primarily, the low pressure area where caritation may occur and means of reduction or elimination. To determine the low pressure area by means of observation through Luc1te windows, plezometer connections and by P1tot tube measurements.

(g) A complete model of the pipe line which included a bell mouth intake, rightangle elbow with special design gulde vanes, Roto-valve with a speclal design plug, and a discharge nozzle ras installed in the laboratory. A section of the plpe line 18 made of Luolte in order to observe the flow condition in the elbow at the guide vane section and in the entrance and discharge end of the valve plug. Three designs of special guide vanes in the elbow were tested. Pressure distribution in the section between two of the guide vanes in the elbow was determined by means of plezometers. P1 tot tube traverses were made to determine the velocity distribution and angle of llow at the discharge end of the guide vane section. Pressure readings were taken at varlous locations in the Roto-valve plug and body. Pressure readings were also taken when the plug was located at several angles of valve opening. A number of changes were made to the valve plug to obtain the best pressure 
condition. The model was tested under fleld head conditions.

(h) The tests are now in progress.

SOUTHERN METHODIST UNIVERSITY, School of Englneer1ng, Dallas, Texas.

(144) AN INVESTIGATION OF THE USE OF THE STANDARD PIPE TEE AS A FLOW MEASURINO DEVICE.

(b) Laboratory project. ( (c) Senlor c1vil engineering atudents.

(d) Prof. I. W. Santry, Jr., School of Englneering, Southern Methodist Un1vero1ty, Dallas, Tex.

(e) General experimental research and student thes18.

(P) The work 18 to determine whether or not such a elmple device as a pipe tee could be used for measuring flow and what rellance could be placed on the results of such a device.

(8) The 1nvestigations of several different atudente w1ll be coordinated in a general paper on this subject to treat with the methods followed and results obtalned. Work 18 planned to cover the effects of the different types of tees, the spacing and location of manometer tubes and P1tot tubes, and the variations caused by age or condition of the tees.

(h) Has not been worked on in several years because of the war, but in the next year the project will be recumed.

(1) Three undergraduate student the ses have been written for partial fulf1llment of the requirements for a B.S. degree in civil engineering:

"The investigation of standard pipe tee as a flow measuring device." A. P. Hundley, Jr.

Investigation of the use of the standard plpe tee as a flow measuring device." R. L. Tate and James K. Walker.

"An investigation of the use of the standard plpe tee as a flow measuring derice." R. L. Goodson, Jr., and W. S. Montgomery.

(145) DISCHARGE RELATIONSHIPS OF CIRCULAR WEIRS.

(b) Laboratory project.

(c) Senior c1vil englneering students.

(d) Prof. I. W. Santry, Jr., School of Englneering, Southern Methodist University, Dallas, Tex.

(e) General experimental research and student thesis.

(P) The research 18 to determine the discharge relationships for circular welrs of both the sharp-edged type and the broad-crested type, and the problems of design of such structures when used as intake structures.

(g) The Investigations of different students will be consolldated into a general paper on this subject that w1ll cover the problems of design of such structures under varying conditions of flow. Only the preliminary work has been done up to the present, but as more students become avallable for thesis work, the problem will be expanded into definite model studies and their actions. In determining the discharge relationships of these velrs, the head and discharge were determined during the process of increasing the head and decreasing the head, showing different characterlotice with the same head. After slfting the data, emplrical equations have been determined for the discharge. In the problem to date, only certaln $812 e$ of welrs bave been coneldered, but elnce the actions of all sizes have proved to be the eame, the advance work can now be considered.

(h) The project has not been worked on for several years, as the equipment was removed during the wor. With the advance work which should start in the next year, new equipment will be built.

(1) Three undergraduate theses have been uritten on this subject to establish the necessery preliminary work:

"Discharge relation of clrcular velro." R. F. Millar. 
"Discharge relation of circular we1rs." $\mathrm{H}$. E. White and J. E. Headington.

"D1scharge relation of c1rcular we1rs." J.D. Mahoney, Jr.

STEVENS INSTITUTE OF TECHNOLOGY, Exper1mental Tow1ng Tank, Hoboken, N. J.

For a resume of the activities of this organization, refer to Laboratory Notes, page 150.

UTAH STATE AGRICUTURAL COLLEGE, Irrigation Research Laboratory, Logan, Utah.

(146) RESEARCH AND DEVELOFMENI OF AN ELECTRONIC NETHOD OF MEABURING HYDROSTATIC PRESSURE.

(b) Utah State Agricultural College, School of Engineering, and the U. S. Geological Survey, Water Resources Branoh.

(c) J. E. Chrlstiansen, Dean of 3chool of Englneering; W. V. Iorns, Project Englneer U. S. Geological Survey; V. E. Hansen.

(d) Vaughn E. Hansen, Utah State Agricultural College, Box 57, Logan, Utah.

(e) Experimental research for stuäent thesis.

(1) To develop a practical electronic pick-up un1t for measuring hydrostat1o pressure that nould be sultable for stream gaging.

(g) The scope of this study is to develop or adapt existing electronic equipment to the measurement of hydrostat1c pressures, as applied to stream gaglng. A survey 18 being made of commerclal companies to find 19 any existing equipment can be readily adapted. The unit selected or developed must be rugged, of low cost, and dependable. The unit must measure hydrostatic pressures equivalent to 10 feet of head, w1th an accuracy of 0.01 foot. In the design contemplated, the fluctuating water level w1ll actuate an element of the electrical circuit located on the stream bed. The 1mpulse will be transmitted to a meter or recorder located on the bank or at some more convenlent point. The fleld of 1rrigation and dralnage 18 badly in need of appliod electronics, to improve 1ts measuring equipment. Th1s study 18 an attempt to supply this deficienoy.

(h) The study 18 st1ll in the 1nvest1gat1onal stage. The laboratory test1ng equipment is completed, but the control element has not yet been constructed.

(151) LINING OF IRKIGATION LANALS AND DITCHE'S.

Cooperat1ve project, Utah State Agricultural College and Soll Conservation Service, listed under above number, Soll Conservation Serv1oe, Irrigation Research Laboratory, Logan, Utah.

UNIVERSITY OF WISCONSIN, Hydraul1c Laboratory, Madison, W18.

(147) RAINFALL-RUNOFF RELATION, BIG EAU PLEINE RIVER.

$\begin{array}{ll}\text { (b) Laboratory project. } & \text { (c) C. C. Warnick. }\end{array}$

(d) Dr. Arno T. Lenz, Hydraul1c Laboratory, University of W1sconsin, Madison, W18.

(e) Thesis study for M.S. degree in c1v1l engineering.

(f) To determine the ralnfall-runoff relation for the B1g Eau Plelne River above Stratford, W18.

(g) Flfteen storms were analyzed and a ratlonal approach sought to express the ralnfall-runoff relation. It was found the base stream-flow at the time of beglnning of ralnfall was an important factor. Base flow and flood flow recession curves assisted in producing a consistent relation when a second storm produced runofi before a prior storm had receded to base flow. 
(h) Projeot in progress.

(1) A brief sumary of progress to date 18 avallable in Wisconsin Valley Hydrolog10 Research Project Report No. 3.

(148) MODEL STUDY OF PROPOSED ENTRANCE STRUCTURES FOR GARY SLIP.

(b) Carneg1e-Illino1s steel Corporation.

(c) A. T. Lenz.

(d) Dr. Arno T. Lenz, Hydraulio Laboratory, Untversity of W1sconsin, Madison, W1s.

(e) Englneering Experiment Station experimental project.

(1) To determine an economical method of reducing wave action in the slip used by ore boats at the Gary Steel horks.

(g) A 1:50 scale model of the entrance of the 246-foot wide allp has been construoted in a new 1l-poot by 40 - foot conorete flume. A structure using lloating type miter gates of varlous designs has been bullt and tested with waves of vary1ng amplitude and length. Breakwater modif1cations w1Il next be tested with a smaller scale model.

(h) Gate tests nearly completed.

(149) EFEECT OF SUBMERGENCE ON DISCHARGE OF SHARP-CRESTED WEIRS.

(b) Laboratory project.

(c) J.R. Villemonte.

(d) Prof. James G. Woodburn, Hydraulic Laboratory, Un1vers1ty of W1sconsin, Madison, W18.

(e) Experimental laboratory study as thesis in partial fulfillment of requirements for Ph. D. Degree.

(1) To substantlate experimentally a new formula based partly on mathemat1cal theory and partly on results obtained by previous investigators.

(g) Tests w1ll be run w1th free and submerged discharge over sharp-orested welrs of varlous shapes -- proportional, reotangular full-w1dth and contracted, clrcular, parabol10, trlangular, and cusp parabol10. Teats will be run at constant discharge with varying degrees of submergence. Special attention w1Il be given to the effect of downstream flow conditions on discharge.

(h) A paper 1s belng prepared sumnarizing previous studies on thls subject on which information is avallable. Equipment is being prepared to begin laboratory tests.

U. 8. DEPT. OF AGRICULTURE, SOIL CONSERVATION SERVICE, North Appalaohian Experimental Watershed, Coshocton, Ohio.

(150) HYDROLOGIC EXPERIMENT STATIONS.

(b) U. S. Soll Conservation Service.

(c) L. L. Harrold, Projeot Superv1sor; Leonard Soh1ff, Hydraul10 Eng1neer; Walter Pomerene, Agrioultural Englneer, F. R. Drelbelb18, Soll scientist.

(d) M. L. N1chols, Chlef of Research, Soll Conservation Service, Washington 25, D.C.

(e) Experimental, for design and general information in planning farms for soll and water conservation.

(1) On whole farm un1ts and watersheds to study the hydrolog10 effect of phys10graphy, t1llage and ground surface conditlons, vegetal covers, and solls and geology. Also to study the effect of conservation larming on runoff and erosion as well as the characterlstics of flood runoff on agrioultural watersheds. On smaller areas studies are made of all the rainfall disposal faotore such as surface runoff, evapo-trensplration, molsture atorage and molsture transmisalon through the sol.1, and percolation of water to the ground-vater teble.

(g) On 1,000 acrea of Government operated land and 5,000 acres of privately owned land, observations of rates and amounts of preolpltation and runoff are made. About 35 recording rain gages and runoff stations are operated. Runoff stations have dralnage areas ranging from 1 to 5,000 aores. Lysimeters, $1 / 500$ acre in area and $g$ feet deep of undisturbed soll and bed rook, are 
used to measure alsposal of rainfall. Three of these soll blooks whl oh are welghed automatically at 10-minute intervals furnish reliable data on evapo-transpiration as well as condensation of molsture from the atmosphere on to vegetation and into the s011. Perlod1c soll-molsture observations in the root zone along with a few continuous records of soll molsture furnish data for the study of molsture movement under different crops in 1 ts relation to the capacity of the 8011 to take up storm rainfall.

(h) About ten years of records are avallable on the lerger watersheds and records for one complete crop rotation on the small watersheds. Thus, sufflolent data are now avallable for a detall preliminary analyals. Such has been started.

(1) Btudies on 8011 molsture relationsh1ps at the North Appalachian Experimental Watershed." F. R. Brelbelb1s and F. A. Post. Proc. Soll Science Soclety of Amer1ca 5: 377-385. 1940 .

"Some of the factors influencing the behavior of perched water tables at the North Appalachlan Experimental Watershed near Coshocton, Oh10." W. D. Potter and Merle V. Baker. Trans. American Geophysical Union, Pt. I: 393-402. 1938.

"An 1nventory of soll water relationships on woodland, pasture, and cultivated so1ls." F. R. Drelbelbls and F. A. Post. Proc. Soll sclence Soclety of Amer1ca 6: 462-473. 1941.

"Some seasonal changes in the pore space and molsture relationships of woodland, pasture, and cultivated so11s." F. R. Drelbelb1s and F. A. Post. Proc. Soll Solence Soc1ety of America 8: 102-108. 1944.

"Btudies of raindrop erosion." W. D. Ellison. Agrioultural Englneering 25: 131-136, 181-182. 1944.

"A survey and discussion of lysimeters and a blbllography of their construct1on and performance." Helmut Kohnke, F. R. Drelbelb1s, and J. M. Dav1dson. U.S.D.A. M1soellaneous Publication $372,1940$.

"Bome influences of frost penetration and microolimate on the water relationshlps of woodland, pasture, and cultivated so118." F. A. Post and F. R. Drelbelb18. Proc. Soll scienco Soclety of Amer1ca 7: 95-104. 1942.

"Results from experimental rain gages at Coshooton, Oh10." Herbert $\dot{s}$. Riesbol. Trans. American Geophysical Union, Pt. I: 542-550. 1938.

"Dual parshall flumes measure wide range of llows." Herbert 8. Rlesbol. C1v11 Eng1neering 9: 17-19. 1939.

"Techniques for hydrologie research." Herbert S. Rlesbol. Agrioultural Englneering 21: 269-273. 1940.

"Bome aspects of subsurface water in hydrologic research on agrioultural watersheds." Herbert B. Rlesbol. Proc. Hydrology Conference, State College, Pa.: 85-112. 1941.

"Watercycle lyslmeters for watershed atudies." Herbert S. Riesbol and G. L. Sherman. Agrioultural Engineering 19: 123-128. 1938.

"Dynamics of water erosion on land surfaces." Leonard Schiff and Robert $\mathbb{E}$. Yoder. Trans. American Geophysical Union, Pt. II: 287-298. 1941.

"Classes and patterns of rainfall with references to surface runoff." Leonard Schiff. Trans. American Geophysical Union, Section of Hydrology, Pt. II: 438-45i. 1943.

"Hydrologic data of North Appalachian Experimental Watershed, Coshooton, Oh10, for 1939." U.S. Dept. of Agriculture, Hydrologic Bulletin No. 1 of Hydrolog10 DIvision, So11 Conservation Service. 1941.

"Hydrologic data of North Appalachian Experimental Watershed, Coshocton, on10, for 1940." Hydrolog1C Bulletin No. 4 of Hydrolog1C Division, Soli Conservation Service, 1942.

An accounting of the dally accretion, depletion, and storage of soll water as determined by welghing monolith lysimeters." L. L. Harrold and F. $R$. Drelbelb18. Trans. American Geophysical Union, Vol. 26, Pt. II: 283-292. 1945.

"Pertinent Iindings from Oh10 Soll Conservation Researoh." H. L. Borst, L. L. Harrold, and R. E. Yoder. O.A.E.S. M1meograph No. 95. 1944. 
"A summary of percolation and other hydrologic data." F. R. Drelbelbis and L. L. Harrold. Soll Sclence Soclety of America, Vol. 10: $451-457.1946$. "Bsine plant nutrient losses in gravitational-water." F. R. Drelbelb18. Proc. Soll sclence Soclety of Amer1ca, Vol. II.

U. S. DEPT. OF AGRICULTURE, SOIL CONSERVATION SERVICE, Irrigation Research Laboratory, Logan, Utah.

\section{(151) LINING OF IRRIGATION CANALS AND DITCHES.}

(b) U. S. Dept. of Agriculture, Soll Conservation Service, and the Utah State Agricultural College, Agricultural Experiment Station.

(c) C. W. Laur1tzen, O. W. Israelsen.

(d) C. W. Laur1tzen, So11 Conservat1on Serv1ce, College H111, Box 179, Logan, Utah.

(e) General experimental research.

(1) To determine the value of materials for lining irrigation canals and ditches 28 a means of conserving water and soll; to obta1n inforiation relative to specifications and management influencing the effectiveness and durability of linings in irrigation canals and ditches.

(g) Investigations will be limited for the most part to earth materials of varlous kinds and fabrics, and such new materials as may be developed. The laboratory 18 located on the Logan River at the mouth of Logan Canyon. The principle feature of the laboratory is four channels simulating canals. The channels are 9 feet wide and 160 feet long. Each ohannel 18 divided 1nto elght seotions, and each section 18 provided w1th independent under-drainage. The stream is continusus in each channel, making it necessary to operate the channels as a unit. In cross-section the ohannels consist of a concrete intercepting basin, on the bottom and in the center of which 18 a 2-inch perforated pipe. Resting on the concrete and over the plpe is an 8-1nch mat of washed and graded gravel. This gravel mat serves as a support for the linings and as a porous medium for conveying the percolating water to

- the perforated pipe and thence to the manbole outlets where $1 t$ can be collected and measured. Tho channels are level and the stream used 18 small, just sufflcient to oliminate dead water. Obviously the erosion factor 18 outside the range of these fac1litiea. Th1s factor 18 not being negleoted entirely, however, the susceptibllity of various lining materials to orosion due to stream characterlstics such as water velocity 18 being studied on a limited scale through the faollity of a fiume located in the hydraulic laboratory in the Englneering Bullding on the eampus of the Utah State Agricultural College.

U. S. DEPT. OF AGRICULTURE, SOIL CONSERVATION SERVICE, St. Anthony Falls Hydraul1c Laboratory, Minneapol18 14, M1nn.

For reports on projects conducted by the Soll Conservation service at the St. Anthony Falis Hydraulic Laboratory, refer to Projects No. 111 to 115, 1nol., pages 37 and 38, 11 sted under University of Minnesota.

U. S. DEPT. OF AGRICULTURE, SOIL CONSERVATION SERVICE, St1llwater Outdoor Hydraul10 Laboratory, St1llwater, Okla.

\section{(152) (931) THE HYDRAULICS OF CONSERVATION CHANNELS.}

(b) Soll Conservation Service, U. S. Dept. of Agriculture. (c) W. O. Ree.

(d) Lew18 A. Jones, Chlef, Div181on of Dralnage and Hater Control, Soll Conservation Service, Washington 25, D. C.

(e) Experimental research at an outdoor hydraulic laboratory. 
(f) To obtain data on the effects of linings, vegetal and non-vegetal, on the water-carrying capac1ty and other hydraulic characterlst1os of channels used in soll and water conservation operations.

(g) Measured flows uo to $150 \mathrm{cPs}$ are passed through outdoor test chennels of varlous cross-sect1ons up to 40 feet 1 w width and slopes up to 10 percent, and measurements of the hydraul1c elements are made to determine the effect of different linings on channel capacity. All work to date has been done on vegetal linings.

(h) Vegetations tested to date include Bermuda grass, weeping lovegrass, sudan grass, yellow bluestem, Smooth brome, and mixtures of native Oklahoma grasses Including little bluestem, rje grass, side oats grama, blue grama, and miscellaneous annuals.

(1) Thls work was formerly conducted at spartanburg, s. C. A technioal bulletin coverlng the South Carolina vegetal studies has been prepared and 18 now awalting publioation.

(153) (933) THE STABIJITY OF CONSERVATION CHANNELS.

(b) Soll Conservation Service, U. S. Dept. of Agriculture. (o) W. O. Ree.

(d) Lew1s A. Jones, Chlef, D1v181on of Dralnage and Water Control, Soll Conservation Service, Washington 25, D. C.

(e) Experimental research at an outdoor hydraulic laboratory.

(1) To obtain data on the protective characterlstics of varlous types of linings, vegetal and non-vegetal, for channels employed in soll and water conservation operations.

(g) The outdoor test channels used in the study of the Hydraul1os of Conservation Channels are also used in this study. For each channel lining, rates of scour or other damage are determined for plows of different veloolties. From these data, permissible velooities for the different covers are determined.

(h) The linings tested to date Include those listed in the study of the Hydraulics of Conservation Channels. In addition, scour rates have been compared for so1ls of different texture with Bermuda grass as a lining.

(1) Thls work was formerly conducted at Spartanburg, S. C. A technlcal bulletin covering the South Carolina vegetal studies has been prepared and 18 now awaling publioation.

U. 8. DEPT. OF CONIERCE, NATIONAL BUREAU OF STANDARDS, Nat1onal Hydraul10 Laboratory, Washington 25, D. C.

Inquirles concerning Projeots No. 154 to 166, 1nol., should be addressed to Chlef, Nat1onal Hydraul10 Laboratory, Nat1onal Bureau of Standards, Washington 25, D. C.

(154) (563) AGING TESTS ON PIPES.

(b) U. S. Treasury Dept. (c) K. H. Be1J. (e) Experimental, design.

(1) To determine the effects of long-continued service on the hydraulio iriction ol plpes.

(g) Specimens of 1-1/2-1nch plpes of nine different materlals have been installed In a cold-water service ilne, and specimens of 3/4-1nch pipes of seven different materials in a hot-water service IIne at the National Bureau of Standards. The hydraulic friction in the se specimeng 1s compared with the Iriction in smooth copper plpes.

(h) Teats before aging started were made in 1936; observation tests were made In 1937, 1938, and 1940. The tests scheduled for 1942 were postponed and are now planned for 1947.

(155) (977) MATHEMATICAL THEORY OF FLOOD WAVES.

(b) U. B. Weather Bureau.

(o) G. H. Keulegan.

(e) General theoretioal research. 
(f) To review and supplement American and foreign literature on the mathematical theory of waves which 18 applicable to the theory of flood waves.

(g) The results of the review w1ll be coordinated and extended by new proofs and additional material to form an integrated serles of papers giving a complete nleture of present knowledge useful in the study of plood waves.

(b) The third paper is nearing completion.

(1) Mathematical theory of Irrotational translation waves." Garbis H. Keulegan and George W. Patterson. J. of Research, Natlonal Bureau of Standards. 24(RP1272): 47-101. January 1940.

"Effect of turbulence and channel slope on translation waves." Garbis $\mathrm{H}$. Keulegan and George W. Patterson. J. of Research, Natlonal Bureau of Standards. 30(RP1544): 461-512. June 1943.

These publications may be obtained from the Superintendent of Documents, Washington 25, D. C., at 10 cents each (stamps not acceptod).

(156) (1328) CONDENSING WATER CIRCULATION。

(b) Bureau of Shlps, Navy Dept. (c) K. H. Be1J. (e) Experimental, design.

(f) Model study of clrculation of hot water discharged from a testing laboratory into a nearly closed shlp basin, to determine (1) rise of temperature at intake of laboretory clrculation system, (2) best location of outlet of system, and (3) other pertinent data disclosed by model tests.

(g) A model of the ship basin on a scale of 1:80 was constructed. Provision was made for simulating tides. Hot-water circulation systems were installed to represent two existing laboratories and the proposed laboratory, with provision for maintaining any desired discharges and temperatures. Temperatures were measured by thermocouples and thermometers. Travel of hot water was made visible using milk as a dye.

(b) All work was completed in August 1941.

(1) A publication covering phases of general interest is under consideration.

(157) FILLING SYSTENS FOR DRY DOCKS.

(b) Sureau of Yards and Docks, Navy Dept. $\quad$ (c) K. H. Belj.

(e) Model studies of gravity illing systems for design.

(f) To check preliminary design and determine necessary modifications for (1) obtalning desired time of flling, (2) obtaining equal flow with low jets from all ports in floor, and (3) providing air relief to reduce cavitation during gate operation.

(g) The main model and 1ts several modifications were bullt on a scale of $1: 8.2$. Numerous smaller models, on a scale of $1: 24$, were used to study sectlons of the fllling systems.

(b) All work was completed in June 1942.

(1) A publication covering phases of general interest is unoer consideration.

(158) MODEL TESTS OF CONCRITE MOORING ANCHORS.

(b) Bureau of Yards and DockB, Navy Dept.

(c) K. H. Be1J.

(e) Experimental, design.

(1) Mosel tests to determine holding power, stability, and possible 1mprovements in design.

(g) Models were dragged at $11 x e d$ slow speeds in a submerged sand bed. Forces, speeds, and positions of the model weru measured. One preliminary design was dlscarded because of 1nstab1l1ty. A second design was tested at scales of $1: 12,1: 8$, and 1:4. Numerous modifloations of shape and dimenslons were tested. It was found that the ratlo of holding power to welght could be considerably inoreased by decreasing the vertical dimension without other change in shape. No other improvement resulted from the tests.

(h) All work was completed in Februery 1943.

(1) A publication covering phases of general interest is under consideration. 
(159) MODEL LAWS FOR DE\&SITY CURRENTS.

(b) Offlce of the Chlef of Eng1neers, War Dept. (c) G. H. Keulegan.

(e) A theoretical study to be supplemented by experimental research.

(P) To determine model laws.

(8) A theoretical analysis of avallable experimental data has been made to determine the nature and scope of experimental research required. Plans for experimental apparatus are being started.

(h) Date of completion is inderinite.

(160) EFFECT OF STORM WINDS ON LAKE LEVELS.

(b) Laboratory project. (c) G. H. Keulegan. (e) Theoret1cal.

(f) To determine surface frictional forces of wind on lake surfaces.

(g) Data on storms over Lake Erle are belng analyzed.

(h) A publication during 1947 is contemplated.

(161) EXTINCTION OF SOLITARY WAVES.

(b) Laboratory project. (c) G. H. Keulegan. (e) Theoret1cal.

(f) To study disalpation of energy.

(g) The theoretical determination of dissipation 18 being compared with experimental results.

(b) A publication during 1947 is contemplated.

(162) FLOW PATTERNS AT PUNP INTAKES.

(b) Laboratory project. (c) O. H. Keulegan. (e) Theoret1cal.

(f) To determine flow patterns.

(g) Patterns are obtalned theoretically by superposition of flelds of olroular vortices and sources and sinks.

(h) A publication during 1947 is contemplated.

(163) SHORT PIPES AND INTAKE8.

$\begin{array}{ll}\text { (b) Laboratory project. } & \text { (c) G. H. Keulegan. }\end{array}$

(1) To determine meihods of computing energy losses.

(e) Theoret1cal and experimental.

(B) A theoretical analysis is being made of the boundary layer development in rough plpes. Th1s will be followed by experimental research.

(h) Time of completion 18 inderinite.

(164) LIMITS OF STACK VENTING.

(b) Federal Public Houeing Authority.

(c) J. L. French, E. E. Ferguson, R. S. Wyly, A. L. Lembeck.

(e) Experimental; to furnish information to code-making authorities.

(f) To investigate the effect on flxture-trap seale of reducing the diameter of the stack in stack-vented house san1tary drainage systems.

(g) Preliminary tests on the siphonage of plxture-trap seals in one and twostory house dralnage syatems have been completed for several sizes of stacks. Additional tests will be made to investigate the effect of reduction in the diameter of stack vents on the self-siphonage of f1xture-trap seals.

(b) Temporarily inactive.

(165) WET VENTS IN PLUMBING SYSTEM8.

(b) Laboratory project.

(c) J. L. French, E. E. Fergueon, R. S. Wyly, A. L. Lembeck.

(e) Experimental. To furnish fundamental knowledge of hyaraulic and pneumat1c conditions in plumbing drainage aystems.

(f) To determine the limits of application of wet venting in plumbing dralnage systems. 
(g) A typioal wet-vented bathtub installation has been made, with the exception that varlous constent rates of discharge are introduced through the wet vent. The deorease in the bathtub trap seal is observed after each discharge of the tub. The rate of discharge through the wet vent; the rate of disoharge of the tub; the length, slope, and diameter of the tub waste; the diameter of the wet vent; the length, diameter, and slope of the draln; and the form of stack litting have been varled. Additional tests have been made with the discharge of standard lavatorles and sinks into the wet vent.

(b) The experimental work has been practically completed, and a report w11l bo written in the near future.

(166) WET VENTING AND SELI-SIPHONAGE TESTS OF PLUMBINO SYSTEMS.

(b) National Housing Agenoy.

(c) J. L. French, E. E. Ferguson, J. A. Reed, R. S. Wyly, A. L. Lembeck, E. J. Norcome.

(e) Experimentaj; to furnish data for use in preparing a Uniform Plumbing Code.

(1) To 1nvestigate the elfeots of stack vacuum on the self-slphonage and wet vent1ng reaults obtalned in Project No. 165 and the completed project, "Self-siphonage of 11xture trapa", reported on page 116, and to obtaln a photographic record of the hydraulic and pnoumat1o phenomena involved in sels-slphonage and wet venting.

(8) One two-story and two one-story house san1tary dralnage systems w1th complete kltchen and bathroom Plxture installatione and with the dralnage system construoted ent1rely of transparent plastio pipe and 11tt1ngs w11l be set up. Motion-plcture records of the varloue flow and pressure phenomond 111 be made while the varlous plxtures are discharged.

(b) Procurement of equipment and materials is in progress. Tests will be started early in March.

3. S. Dept, of Commerce, Weather Bureau, Washington 25, D. C.

(167) DEVELOPNENT OF RIVER FORECASTING TECHNIQUES.

(b) U. S. Weather Bureau. (c) M. Bernard, R. K. Linsley, Jr., M. A. Kohler.

(d) Chler, U. 8. Weather Bureau, Washlngton 25, D. C.

(e) Experimental project under the Bureau's program of procedure development.

(1) To develop procedures wh1ch w111 permit more acourate and more t1mely river forecasts, or w1ll inorease the operating efflelenoy of existing foreosting Btals.

(g) The projeot Involves a combination of basic theoretical hydrology and stat1sties to make meximum use of ava1lable data. New instruments and prooedures are reviewed to determine whether they may be used direotly or by adaptation. Orlginal 1deas presented by the staff are revlewed, techniques developed and tosted by actual trial in comparison with existing methods. Investigations aro alled at the following problems: (I) Forecasting the runoff erom ralnsal1; (2) d1stributing runoff in time to predict the outrlow from a basin; and (3) routing and colbining flows Irom tributarles to predict llood-wave movedent downatream.

(h) This 18 a cont1nuing project and no phsse can be reported as complete. Developments under (1) and (3) above are well advanced and technlques are now undergolng exhaust1ve tests to determine possibility of and need for further replnoment. A pllot project under (2) above hes been completed and plans for comparat1ve testing of three original ldeas are being formulated.

(168) SEASONAL WATER SUPPLY FORECASTING INVESTIGATIONS.

(b) U. 8. Weather Bureau. (c) M. Bernard, R. K. Linsley, Jr., M. A. Kohler。

(d) Chle1, U. S. Weather Bureau, Washington 25, D. C.

(e) Experdmental projeot under the Bureau's program of procedure development.

(1) For development of forecasting procedures. 
(g) The project 18 intended to (1) develop by statistical means a relation between preclpitation, other meteorological factors and runoff for forecasting total seasonal runoff volume; and (2) develop the relations between meteorological data and time distribution of runoff for predicting inorements of runoff for varlous time intervals. The project requires as a part of the solution the determination of the most effective statistical treatment8, both graphical and analyt1cal; the establishment of oriterla for selection of representat1ve meteorological stations and the development of methods of adjusting old records for differences in measurement technique and other effects which introduce a time trend into the record.

(h) A technique under 1 tem $(g-1) 18$ complete and under test to determine if further refinement is just1fled. Investigations under 1 tem (g-2) have just begun.

(1) Referenoe to preliminary work, Foreoasting seasonal runoff by statist1cal methods." Ph1ll1p L1ght and Max A. Kohler. Trans. American Geophys1cal Union, Pt. II. 1943.

U. 8. DEPT. OF THE INTERIOR, GEOLOGICAL SURVEY, Washington 25, D. C.

(169) UNSATURATED FLOW OF WATER IN RELATION TO GROUND WATER RECHARGE.

(b) U. 8. Geological Survey, Water Resources Branch, Ground Water DIvision.

(c) W. 0. Smith.

(d) Water Resources Branch, U. S. Geological Survey, Washington 25, D. C.

(e) Experimental and theoretical.

(1) Mechan1cs of nonsaturated flow of water in porous bodies.

(g) Preliminary experimental work has shown the factors to be cons1dered. Apparatus has been designed for quantitat1ve measurements.

(170) THE SPECIFIC YIELD OF ROCKS FOR WATER.

(b) U. S. Geolog1cal Survey, Water Resources Branch, Ground Water D1v1s1on.

(c) W. O. Sm1th.

(d) Water Resources Branch, U. S. Geological Survey, Washington 25, D. C.

(e) Experimental and theoretioal.

(f) Mechanics involved in the determination of specific yleld of porous media.

(g) A theoretical analys18 of the problem has given the factors determining the spec1f1c yleld of rocks and a theoretical relation from whlch the spec1f1c yleld may be found has been developed for uniform sanda. It has been checked with fleld data.

(h) A paper 18 being prepared.

U. S. DEPT. OF THE INTERIOR, BUREAU OF RECLAMATION, Denver, Colo.

(171) SEDIMENTATION STUDIES.

(b) Bureau of Reclamation. (c) Hydraul1c laboratory.

(d) Chlef Engineer, Bureau of Reclamation, Denver, Colo.

(e) Experimental study for general information.

(1) To check avallable formulae for sediment transportation and establish the relative effect of changes in flood discharge peaks and silt detention reservolrs on tributaries.

(g) A plume 2 feet wide and 130 feet long w1ll be ut1lized. In1tially a uniform flne sand will be used to establish and demonstrate varlous factors such as slope, water and sol1d discharge, and such conditions as equillbrium aggradation and degradation. The length of plume exceeds that used in past exper1-. ments to minimize end effects.

(b) Under construction. 
(172) GAVITATION STUDIES.

(b) Bureau of Reclamation.

(c) Hydraul10 laboratory.

(d) Chlef Eng1neer, Bureau of Reclamation, Denver, Colo.

(e) Experimental etudy of a basio nature.

(P) To contribute fundamental information towarde a more complete understanding of cavitation.

(g) By use of a magneto-striction osc1llator to set up cavitation for visual and high-speed photograph1c study. Attempt8 w1ll be made to photograph the cavitles in auccessive stagee of their development. Some experimental work connected with the resletance of some of the newer material to cavitation eroelon 18 aleo contemplated.

(b) Equipment nearing completion. Cooling problem not completely solved.

U. S. NAVY DEPT., DAVID TAYLOR MODEI BABIN, Washington 7, D. C.

Inquiries concerning Projects No. 173 to 178, 1nol., should be addressed to The Director, Dav1d Taylor Model Basin, Washington 7, D. C.

(173) STATISTICAL ANALYSIS OF TURBULENT FLOW IN TUBEB.

(b) Navy Dept. $\quad$ (c) P. Elsenberg, J. V. Wehaueen, M. S. Maconsky.

(e) Experimental and theoretical 1nveetigations for general information.

(1) To investigate methods of describing turbulenoe and to obtain correlations with roughness and pressure change.

(g) The ultimate alm is to obtain correlations of turbulence with friotion losses over a wide range of Reynolds numbers. Inltial analys1s is to be made Prom photographs of particles injected into the stream. Other methods, inclualng attempts to measure preesure fluctuations, w1ll also be undertaken.

(b) A preliminary set-up has been made, ueing underwater flow in plaetio tubing. The particle injection eystem has been inetalled and experimente on methods of photogrsphy have been completed. Actual tests w11l begin in January 1947. The design of a facllity 10 under way for obtalning flows up to 150 fps under heads up to 700 leet of water obtalned by a1r pressure for tests at high Reynolds numbers. Theoretical work on methods of analysis 18 also being carrled porward.

(174) CIRCULATI NG WATER CHANNEL.

(b) Laboratory project.

(c) C. E. Bovers, C. A. Lee.

(e) The design, construction, and calibration of a clrculating water channel to be used as a teet facillty.

(P) The purpose of the facility is to proviae a stream of flowing water with an essentlally plat surface free from waves and having a unfform velocity throughout the test sect1on.

(g) Three 1:22 scale models of the full scale olrculating water channel have been designed, conetructed, and teeted. A full scale clrculating water channel has been conetructed and partlally callbrated. The full ecale water channel test section 1822 peet wide, 9 peet deep, and 60 peet long. The water ohannel structure le a vertical closed loop with the test section situated in the upper horizontal leg. The facllity 1. powered by two 1000hp motors driving two vertically set adjustable blade propeller type pumps. The pump blades are adjusted for speed control which can be maintalned to \pm 0.01 of a knot.

(b) Studies are being continued in the $1: 22$ ecale model on alterations to the full-ecale water channel. The full acale channel has been in operation ae a test fac1lity for the past elghteen months. A manual for operation of the facility is in preparation.

(1) Reports and papers on all known attempts to construct a fac1l1ty of sim1lar nature have been collected and w11l be furnished to interested parties upon requeet. 
"The clrculating water channel of the Dav1d W. Taylor Model Basin." Capt. H. E. Saunders, U.S.N., and Lt. Comdr. C. W. Hubberd, U.S.N.R. Trans. Soc. of Naval Arch. and Marlne Engrs., Vol. 52: 325-364. 1940.

"The characterlst1cs and ut1lization of the Dav1d W. Taylor Model Basin clrculating water channel." C. A. Lee. Proc. Th1rd Hydraulics Conference, Iowa Inst1tute of Hydraulic Research, State Un1versity of Iowa, Iowa C1ty, Ia.

(175) VARIABLE PRESSURE WATER TUNNELS.

(b) Laboratory projeot.

(c) W. F. Brownell, C. A. Lee.

(e) The design, construction, and calibration of a varlable pressure water tunnel to be used as a test facllity.

(f) To provide a jet of water approximately 60 inches in diameter and traveling at a speed of 50 knots. Prov1slons w1ll be made to vary the pressure of the jet irom pressures approaching vapor pressure to at least 4 atmospheres.

(g) A search of 11 terature on all exlsting water tunnels has been made. Many of the existing tunnels have been v1sited by the Director and members of the Taylor Model Basin staff. A search of literature has been made on the component parts of the tunnel such as contraction, diffuser, gulde vanes, pumping plant, etc. Studies are in progress on guide vanes and elbows at the St. Anthony Falls Hydraulic Laboratory, University of Minnesota. A $1: 10$ scale model 18 under construction at St. Anthony Falls and will be completed and ready for test in the near future. The Iowa Institute of Hydraulio Research 18 conducting tests on the degree of turbulence produced by screens and grids and the effect of model size on the jet of a water tunnel. The Taylor Hodel Basin 18 designing a $1: 4$ scale model which w1ll have an operating speed of 50 knots and have the same varlation in pressure as the pullscale water tunnel. Special attention 18 belng directed toward the design of a test section which will be readily removable.

(h) A three volume bibllography of existing water tunnels and a five volume hydraulic design study have been completed. Preliminary plans and specifications for the mechanical, structural, and electrical designs are nearing completion.

(1) Reports and papers on all known water tunnels as mentioned in (h) are avallable for study and will be furnished to interested parties upon request.

See Project No. 105. University of Minnesota, ana Project No. 73 ana No. 80, State University of Iowa.

(176) MODEL TEST INVESTIGATION OF STREAMLINED GUN SHIELDS FOR 5-INCH GUN MOUNTS.

(b) Bureau of Oranance, Navy Dept. (c) R. S. Gerthune, J. Wehausen, C. A. Lee.

(e) Theoretical and experimental for design and for general information.

(e) To determine the best shleld shape to resist damage due to water-wave 1mpact as occurs on the forward gun turret of the 692 class destroyer. To review and to supplement the literature on water-1mpact pressure and on water-vave 1mpact phenomena.

(g) Attempt by mathematical and analytical means to predict water-1mpact pressure and to predict the change in pressure distribution w1th time when bodies of simple shape are dropped Into water. Conduct drop tests with bodies of simple shape and with model gun shields to determine experimentally the magnitude and varlation of the water-impact pressure. The bodies dropped w1Il be equipped with elther plezoelectric gages or diaphragm type strain gages for the purpose of pressure measurement. Conduct shlp model tests to learn more about the wave phenomena when waves strike a ship in motion into the waves.

(b) Experimental equipment for conducting the laboratory tests 18 belng designed and constructed.

(1) "Uber Stoss-und Gle1tvorgänge an den Oberflächen von Füssigke1ten." H. Wagner. Ze1t. Jür Angew. Math. U. Keoh. 12: 193-215. 1932.

"On the 1mpact of a heavy body upon the surface of an incompressible plu1d." L. I. Sedov. C.A.H.I. 187. 1934. (Russ1an.)

"Resistance of lmpact on vater surface." shumpel Watanabe.

sc1. Papers, Inst. Phys. Chem. Res., Tokyo, 12: 251-267. 1930. 14: 153-168. 1930. 23: 118-135, 202-208, 249-255. 1933-34. 
"Force and pressure measurements on V-shapes on impact with water compared with theory and seaplane alighting resultB." E. T. Jones and R. W. Blundell. Reports \& Memo No. 1932. 1938.

"Der Elndringwlederstand von Körpern mit varschiedenen Kopflormen bel senkrechten Aufschlag auf Wasser." A. Welble. Dout UM 4541. 1943.

\section{(177) BENTONITE CHANNEL.}

(b) Laboratory project.

(c) B. Rosenberg, C. A. Lee.

(e) Experimental research.

(1) To develop a new means for quant1tat1ve and qualitat1ve studies of plom around underwater bodies.

(g) By ut1lizing the double refraction properties of ilowing colloldal solutions of Bentonite clay, photographs showing the viscous shear pattern around an underwater body can be obtained. A teohnique using polarized light to obtain the shear pattern in the flowing colloldal solution w1ll be used. Fhe shear patterns w11 be studied and by numerical or graphlcal integration the velocity distribution may be obtained. Preliminary investigations will be twodimensional in character, but later it is planned to extend the scope of the 1nvestigations to three-dimenalonal bodles.

(h) The Bentonite channel is under construction and a preliminary report of the technlque to be used $1 \mathrm{~g}$ belng completed.

(1) Walter Leal. Mech. Engr. 586, September 1945.

R. Weller, D. S. Middlehurst and R. Steiner. Technical Note No. glt NACA. February 1942.

"Advanoes in Collold Solence." J. T. Edsall. Interscience Publlehers, New York, N. Y., Vo1. 1: 269. 1942.

(178) VORTEX-EXCITED VIBRATIONS OF CIRCULAR CYLINDERS.

(b) Navy Dept. (c) L. Landweber, P. Elsenberg, M. S. Maconsiry。

(e) Experimental and theoretical investigations for general snformation.

(P) To obtaln correlations of drag, slde force, and vortex configurations of vibrating cylinders, including the effeot of forcod vibrations on the resultant vortex formation.

(g) The preliminary phases of the project wll 1nclude invostigations of the relation between imposed lateral motion and the resultant arag with a time correlation of the vortex pattern behind Gmooth cylinders at low Reynolds numbers. The work w1ll progress to 1ratsintaneous timo gostelationg of the Blae forces, drag forces, and velocity alstrlbutions in the wake to determine the strength and geometrical conflguration of vortices shed from a smooth circular cylinder. These data will then be correlated with the instantaneous pressure distribution about a vibrating cylinder. Specialized phases of the project will follow with investigatlong of the effect of suriace roughness and more complicated shapes and nodes of vibration.

A spec1al "minlature" model basin 1 being designed in which tasts will be made of free and forced osclllations with contlnuous recording of the forces. A glass test section w111 be used for photogyaphing the vortex pattern at the lower Reynolds numbers. Instrumentation for velocity msasurements in the wake w11 be considered at a later date. The pressure distributions on a vibrating cylinder w1ll be made in the lagge model basing at the raylor Model Basin.

(h) Methods of 11ghting and photographing the wake are being invest1gated. The miniature model basin and its osolilator and dynanometere are in the design stageb. 
U. S. NAVAL ENGINEERING EXPERIMENT STATION, Annapolis, Ma.

(179) CORROSION TESTS OF PIPING, FITTINGS, AND CONDENSER TUBES.

(b) Laboratory project.

(d) Commanding Officer, U. S. Naval Engineoring Experiment Station, Annapolis, Md.

(e) Experimental, for future design.

(f) To obtain information as to effect of water velocity on the corrosion rate of non-ferrous pipe materials, and to determine the influenoe of fittings and joint design on service life.

(g) Water from the Severn River has been pumped through piping syetems under controlled conditions. A permanent naval oorrosion test site is be1ng established at Kure Beach, North Carolina, to make testa 1n sea water.

(h) A oontinuing projeot.

(1) similar studies have been made of materials for propellers.

"Invest1gation of materials for marine propellers." W1lilam C. Stewart and W. Lee Williams. Paper presented before the annual meeting of the American Soclety for Testing Materlals at Buffaio, N. Y., June 1946.

THE PANAMA CANAL HYDRAULIC LABORATORY, D1ablo He1ghts, Canal Zone.

(180) HYDRAULIC MODEL OF PANAMA CANAL AT SEA LEVEL.

(b) Special Eng1neer1ng Division, Department of Operation and Ma1ntenanco, The Panama Canal (laboratory project).

(c) Hydraulic section personnel under the eupervilion of J. S. Meyers.

(d) The Supervising Eng1neer, Speolal Eng1neer1ng D1v181on, Diablo Heighto, Canal Zone.

(e) Project 18 part of the Isthmian Canal Studies, 1947, authorized by Publ10 Low 280, 79 th Congress, to 1nvestigate means for 1noreasing the oecurity and capacity of the panama Canal.

(1) To afford a means of checking theoret1cal oomputations of hydralic phenomena in a sea-level oanal, especlally the current velocities resulting from the difference in tidal ranges of the Atlant1c and Pac1f1c Oceans at the Isthmus, and to obtain a more reallatic concept of the whole projeot.

(g) Invest1gations are being conducted on a hydraulio model with undistorted. scale rat10, model-to-prototype, of 1:100. The half mile long sea-level canal model reproduces the Atlantic and the Pacific entranoes and follows the route of the present canal. Tides are reproduced in minlature at both entranoes by eleotro-mechanical tide machines. Provisions have been made for testing varlous widths of canal, for observing effects of tributary flood flows on tidal flow in the canal, and for studying the need of tial regulating struotures in the Pacifio entranco.

(h) Construction of the model has been completed recently and initial tests undertaken.

U. 8. WAR DEPT., OFFICE OF THE CHIEF OF ENGINEERS, Beach Erosion Board, Washington, D. C.

Inquirles ooncerning projects No. 181 to 185 , 1 ncly should be adaressed to The Resident Member, Beaoh Erosion Borrd, Little Falls Road, N.K., Washington, D. C.

\section{(181) EQUILIBRIUM PROFILE OF BEACHES.}

(b) Beach Erosion Boara, Corps of Engineers.

(o) J. M. Caldwell, F. J. Syrewar.

(e) Experimental researoh. 
(f) To evaluate the effect of wave form and sand grain size in determining the equilibrium propile of beaches.

(g) Clean sand is placed in the large concrete wave tank, 88 leet by 14 leet by 4 feet, at the Beach Erosion Laboratory. Waves having selected character1 st1cs are generated therein and allowed to shape the beach to a stable proflle for the particular wave belng studied.

(b) One sand has been tested under a single selected wave helght for three different wave lengths and wave perlods. The three runs consisted in retalning the wave helght constant and doubling and tripling the wave length of run 1 for runs 2 and 3. The runs were cont1nued unt11 an apparentis stable condition of the beach resulted. Further tests are yet to be conducted, using beaches of different initial slopes and with different grades of sand.

(1) Quarterly Summary, EngIneer Department Investigations in Hydraul1cs, So11 Mechan1cs, and Conerete, War Department, Corps of Englneers, Watermays Experiment station.

(162) STUDY OF WAVE REFLECTION.

(b) Beach Erosion Board, Corps of Engineers.

(c) J. M. Caldwell, L. H. Senser.

(e) Experimental Research.

(1) To determine the amount of energy absorbed by varlous types of beaches, bulkheads, and breakwaters when subjected to wave attack.

(g) solitary wave crests are made to 1mpinge upon varlous substances mounted in the end of the tank in which the crest 18 generated. The energy loss resultIng from the impingement 18 determined.

(h) Tests are belng made in a wooden llume 66 feet long and 7 inches by 10 inches in cross-section. A special type of wave generator 18 used to generate tho solitary wave used in the study. Var1ous substances and beach slopes are placed at one end of the tank and the energy-absorbing characterist1cB determined.

(1) Quarterly Summary, Englneer Department Invest1gations in Hydraul108, So1l Mechan1cs, and Concrete, War Department, Corps of Eng1neers, Waterways Exper1ment Station.

(183) SETTLING VELOCITY OF BEACH SANDS.

(b) Beach Erosion Board, Corps of Engineers.

(e) Experimental research.

(1) To develop an instrument for classifyling beach sand samples according to settling velocities lnstead of grain $B 120$.

(g) The ultimate goal of the instrument for determining the setting velocities of sand samples is $_{\mathrm{s}}$ to obtain an accurate record of the velocity distribution of a representative beach sand sample. It is belleved that the settling velocity of beach sand 18 an important parameter to consider in the analysis of beach erosion problems.

(h) Preliminary tests on the 11rst apparatus designed 1ndicated too much 1nertia effect and systemat1c error in the measuring system. Further studies are now under way to develop an apparatus free from these errors.

(1) Quarterly Summary, Englneer Department Invest1gations in Hydraul1c8, So11 Mechanles, and Concrete, War Department, Corps of Englneers, Wateruays Experiment station.

(184) STUDY OF MODEL SCALE EFFECTS.

(b) Beach Erosion Board, Corps of Englneers.

(c) J. M. Caldwell, F. J. Syrew10z.

(e) Experlmental research.

(f) To determine the laws of model slmllarity governing the action of waves on movable sand. beaches.

(g) The study is belng made in the steel plume, 42 feet by 1.5 feet by 2 feet, at the Beach Eroslon Board. Condltions of wave helght, wave length, wave perlod, beach slope and grain slze are adjusted to a predetermined scale in an attempt to slmulate the results of the tests obtained in the concrete 
tank for the Equilibrium Proflle study (Project No. 181).

(h) Tests have been conducted, using scales of $1: 2$ and $1: 2.5$. Further tests are in progress ut1lizing other sand s1ze rat1os and other soale representation.

(1) Quarterly Summary, Engineer Department Inveatigat1ons in Hydraul1c8, So1i Kechanlcs, and Conorete, War Department, Corps of Engineers, Waterways Experiment Station.

(185) STEEL SHEET PILING INVESTIGATION.

(b) Beach Erosion Board, Corps of Englneers. (c) C. Ross (report)

(e) Experimental research.

(1) To determine the probable life of a steel sheet plling installed under variable conditions, and the causes of fallure and methods of prevention.

(g) Thlckness measurements of represontative steel sheet piling samples located along the East Coast were taken in 1936, 1940, and 1946. Measurements wero taken above hlgh water, at hlgh water, between hlgh and low water, and at low water. When avallable, data on salinity, $\mathrm{pH}$, water temperature, and pollution were also complled.

(h) The data obtalned have been complled and are in the final stage of analyols.

(1) Quarterly Summary, Engineer Department Invest1gations in Hydraulics, So1l Mechanics, and Concrete, War Department, Corps of Englneers, Waterways Experiment Station.

U. S. WAR DEPT., CORPS OF ENGINEERS, LOS ANGELES DISTRICT HYDHAULIC LABORATORY, Los Angeles 14, Cal11.

Inquirles concerning Projects No. 186 to 188, 1ncl., should be addressed to The D1strict Eng1neer, Los Angeles District, Corps of Engineers, 751 South Figueroa Street, Los Angeles 14, Cal11.

(186) SUPERELEVATED FLOW IN CURVED OPEN CHANNEL8.

(b) War Dept., Corps of Englneers, Los Angeles District.

(c) Hydraul1c Design Un1t, A. P. G1ldea, Chler.

(e) Experimental.

(f) To provide design orlteria for hlgh velocity flow in curved reotangular channels.

(g) Series of model tests to check theoretical criteria for transition spirals and superelevated bottoms for rectangular channels.

(h) Work curtalled at present. No lmmediate resumption contemplated.

(1) Inter1m Report, Hyaraulio model study, superelevated flow in curved open channels." U. S. Engineer Offlce, Los Angeles District, Callfornia, December 1945.

(187) HYDRAULIC MODEL STUDY, LOS ANGELES RIVER CHANNEL IMPROVEMENT, STEWART AND GRAY ROAD TO PACIFIC ELECTRIC RAILWAY.

(b) War Dept., Corps of Eng1neers, Los Angeles District.

(c) Hydraulic Design Un1t, A. P. Glldea, Chiel. (e) Design.

(f) To determine confluenoe losses and water surfaces for varlous types of bridge construction (clear span, multiple span, 1 ze and shape of plers).

(g) A 1:50 scale model of the ent1re channel 1mprovement under conolderat1on has been constructed and measurements made to determine water-surfaco prop1les at the confluence w1th Rio Hondo and at the varlous bridges.

(h) Tests have been completed. Data are belng analyzed.

(1) Report w1ll be prepared in the near future.

(188) HYDRAULIC MODEL STUDY, LOS ANGELES RIVER CHANNEL IMPROVEMENT, WHITSETT AVENUE TO TUJUNGA WASH.

(b) War Dept., Corps of Engineers, Los Angeles District. 
(c) Hydrauldo Design Unit, A. P. G1ldea, Chler. (e) Design.

(i) To deternine effect on water surface of gerles of ourves and reverse ourves with trans1tion sp1rals and superelevated bottoms for rectangular channels

- with varlous diecharge日. Also to determine llow conditions at the confluence with Tujunga Wash for varlous combinations of discharges.

(g) A 1:30 scale model of a portion of the upper Los Angeles River channel 1mprovement under consideration has been constructed. Depth and veloolty distribution measurements to be taken.

(b) Teste have been partially completed. Work curtalled at present. No 1mmedlate resumption contemplated.

U. 3. YAR DEPT. CORPS OF ENGINEERS, PORTLAND DISTRICT, Portland, Ore. (Bonnev1lle Hydraul10 Laboratory).

Inquiries concerning Projeots No. 189 to 192, 1ncl, should be addressed to The Distriot Englineer, 628 P1ttock Block, Portland 5, Ore.

(189) GENERAL MODEL STUDY OF MONARY DAM, COLURBIA RIVER, UMATILLA, OREGON.

(b) War Dept., Corps of Engineers, Portland District, Portland, Ore.

(c) R. B. Cochrane, Head, Hydraulic Design Section, Portland D1strlct.

(e) Experimental, design.

(1) Experimental study to assiat in structure allgnment and design of navigation approaches, flshway approaches and 11shways, powerhouse tallrace, and cofferdems.

(8) A flxed bed conorete type 1:100 scale undistorted model, covered by an 85loot by 220-loot ghelter, reproduces a 3.7-m1le reach of the Columbia River. After verlification of natural river bed conditions, the powerhouse, sp1llway, look, and flehway structures were 1nstalled, and are belng teeted under various conditiong to determine the best alignment and design of those structures. Provisions have been provided to obtain water surface elevations, velocit1es, current directlons, and photographs at flows rangIng from 40,000 to 2,200,000 cfe for comparison purposes.

(h) Verlfication tests on 1:100 scale model have been completed and preliminary report 18sued. Tests are under way on structure al1gnment and powerhouse tallrace design.

(190) MODEL STUDY OF MONARY DAM SPILLWAY, COLUMBIA RIVER, UMATILLA, OREGON.

(b) War Dept., Corps of Englneers, Portland Dietrict, Portland, Ore.

(c) R. B. Cochrane, Head, Hyaraulic Design section, Portland Disir1ct.

(e) Experimental, design.

(1) Experimental study to determine the hydraulic characteristics of the spillway otructure, including crest shape, pler design, gates, and stiling basin detalls.

(g) A 1:36 scale model of plexiglase and waterproofed plywood w1ll reproduce three complete 50-100t width bay of the splllway section, including crest, plers, gatee, and st11ling basin. The model w1ll be in a brick and glass flume 5 peet wlde, 6 seet hldk, and 70 peet long. Provision w1ll be mado for obtaln1ng water surface proplle, veloclt1eg, and pressures under various condition of head on the gates up to 50 feet. An auxillary 1:10 scale sectlonal model of the proposed vertical lift gate is contemplated Ior the ruture.

(h) Construction of the $1: 36$ scale sectlonal model 1 s currently under way and nearing completion.

(191) MODEL STUDY OF MONARY DAM NAVIGATION LOCK, COLUMBIA RIVGR, UMATILIA, OREGON.

(b) War Dept., Corps of Englneers, Portland District, Portland, Ore.

(o) R. B. Cochrane, Head, Kydraul1c Design Section, Portland District.

(o) Exporimental, dosigi. 
(f) Experimental study to determine the hydraulio design features of the navigation lock fllling and emptying systems.

(g) The look hydraulic system w111 be investigated in a 1:25 scale model construoted of waterproofed plywood and transparent plast1cs. A section of the forebay, the ent1re 86-foot by 500-10ot look, and lower look approaoh ohannel have been slmulated, as well as the ports, culverts, and control valves of the flling and emptying systems. Provision will be made to operate the valves electrloally and to obtaln hawser stresses through a range of head conditions up to 92 feet. A separate 1:20 soale auxillary model has been constructed to facllitate valve deslgn.

(h) Construction 18 under way on the main lock model. An eccentrio-seal, steelcase-enclosed tainter valve is being tested in the auxillary 1:20 valve model.

(192) (1334) MODEL STUDY OF SPILLWAY AND OUTLET WORKS, DORENA DAM, ROW RIVER, OREGON.

(b) War Dept., Corps of Eng1neers, Portland Distrlct, Portland, Ore.

(c) R. B. Cochrane, Head, Hydraul1c Design Section, Portland Distriot.

(e) Experimental, design.

(1) The model was construoted to a scale of $1: 50$, and the converging chute spillway was constructed of plywood, the tower intake and oulvert of the outlet works of pyralin, and the forebay, dam seotion, and tallbay of concrste. The revised non-converging chute spillway and pive slulce outlets were construoted in pyralin with a plywood stilling basin. Data were obtained on orest coefflclent, shape of abutment, baffle size and arrangements, stllling basin floor elevation, and the broad type of end sill.

(g) The initial purpose of the study was to determine the hydraulic characterlstios of the spllimay and outlet works as originally designed, and to develop means of correcting any undesirable features. The second phase of the study was made to investigate hydraul10 features of the revised spillway deslgn with special emphasis on designing st1ling basin and broad end s111 to obtain hyaraulic $j$ ᄀ at maximum discharge under deficlent tallwater conditions.

(b) Testing of the oonverging type splllway and tower culvert type of outlet works of the original design have been completed, and Bonneville Hydraulic Laboratory Report No. 11-1 18sued on November 16, 1942. Construction has been completed and tests are in progress on baffle size and arrangement, end sill elevation, and stilling basin floor elevation of the revised nonconverging chute spillway.

U. \&. WAR DEPT., CORPS OF ENGINEERS, ST. PAUL DISTRICT, St. PQUI 1, MInn.

Inquirles conoerning Projeots No. 193 to 198, 1nol., should be addressed to

The District Englneer, Corps of Englneers, War Dept., st. Paul 1, Minn.

(193) AIRFIELD DRAINAGE STRUCTURES INVESTIGATION.

(b) Office, Chlef of Eng1neers, Corps of Englneers, War Dept., Washington, D. C.

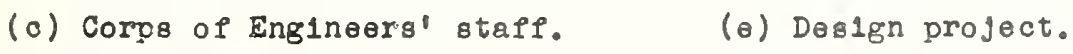

(f) To determine the hydraul10 characterist1cs of paved alrfield gutters under various conditions of roughness, surface texture, and gradients; to determine discharge characterist1cs of typlcal comerclal inlet grating and the most efflolent layout for varlous condltions of surpace; and to determine discharge characterlstics of curb inlets for varlous approach slopes.

(g) The investigation will be conduoted in three full-sosle models slmulating: (1) a portion of pavement slab and gutter of conorete poured in succesive courses to produoe gradients of $0.25,0.75,1.0,1.5$, and 2.0 peroent:

(2) various types of commercial inlet gratings; and (3) curb gutter intakes.

(b) Design of the models has been started. The slte for the model of pavement slab and gutter has been prepared. 
Corps of Engineers, st. Paul

(194) A STUDY OF METHODS USED IN KEASUREMENT AND ANAIYSIS OF SEDIMENT LOADS IN STREAMS.

(b) Federal Inter-Agenoy River Basin Comm1ttee, Sub-commlttee on Sedimentat1on.

(c) Representatives of cooperating agenoles.

(e) Experimental and design project.

(1) To 1mprove the methods and equipment used in the measurement and analysis of the sediment load in streams.

(g) After a survey was made of previously used suspended sediment sampling equipment, fleld technique, and laboratory methode, lmproved designs of point-integrating and depth-1ntegrating sediment samplers were bullt and new laboratory methods were developed. The new amplers were sent to offlces of the cooperating agencles throughout the country for extensive fleld testa. On the basla of these teats, 1mprovements have been made in the mechanical operation of the polnt-integrating ampler, and a program has been inltiated to dovelop depth-integrating samplers to oover a wider range of sampling conditions.

(b) The testing program is in progress.

(1) Progreso reports have been lssued as follows:

"Fleld practice and equipment used in sampling suspended sediment." CE-A No. 1. August 1940.

"Equipment used for sampling bed load and bed material." CE-A No. 2. September 1940.

"Analytical study of methods of sampling suspended seälment." CE-A No. 3. November 1941.

"Kethods of analyzing sediment samples." CE-A No. 4. November 1941.

"Laboratory Invest1gations of euspended sediment samplors." CE-A No. 5. December 1941 .

"A atudy of new methods for a1ze analja1s of suspended sediment samples." CE-A No. 7. June 1943.

"Density of sediments deposited in reservo1rs." CE-A No. 9. November 1943. "Fleld conferences on suspended sediment sampling". Martin E. Nelson. September 1944.

"Progress report, Comparative pleld tests on suspended sediment samplers." Nartin $\mathrm{E}$. Nelson and Paul C. Benedict. December 1944.

"Study of methods used in measurement and analyols of sediment loads in streams." Mart1n E. Nelson and Paul C. Benedict. Paper presented at tho annual convention of American Soclety of C1vil Englneers, Spokane, Wash. July 1946.

(195) OHIO RIVER, FILLING AND EMPTYING SYSTEMS FOR NEW CIMBERLAND LOCES.

(b) P1ttaburgh Pennsylvania D1strict, Corps of Englneers, war Dept.

(c) Corps of Engineers' staff.

(e) Design project.

(1) To check the proposed design of the flling and emptying syatems for the New Cumberland main and auxiliary locks and to develop improvements in the syetems.

(g) 1:25 scale models have been bullt to simulate the design of a main lock 110 feet wlde by 1200 feet long, and an auxll1ary lock 110 feet wlde by 600 feet long. The normal lift 1822.1 feet. To reduce chamber turbulence, revisions have been made or proposed in the design of chamber ports of the side-f1lling system for the main lock and in the design of the lateralo of the bottou-flliling system of the auxlliary lock. Investigations have been made of the currents in the forebay of the maln look and turbulence in the tallbaya of both locks.

(h) Design and construction of the models have been completed. The testing program was in progress when work on this project was temporarily suspended. 
(196) MISSISSIPPI RIVER, FILLING AND EMPTYING SYSTEM FOR NEW 1200-FOOT LOCE AT LOCK AND DAM NO. 19, KEOKUK, IOWA.

(b) Rock Island Ill1no1s District, Corps of Engineers, War Dept.

(c) Corps of Engineers' otaff.

(e) Design project.

(f) To study the design of the proposed plling and emptying systemg for a new 1200-foot lock at Lock and Dam No. 19, Including the use of a submerg1ble tainter gate as the upper lock gate to supplement the 1111 ing system.

(g) A 1:25 scale model slmulates a lock 110 reet w1de by 1200 feet long w1th intermediate gates to provide 800-poot and 400-10ot chambers. The normal $11 \mathrm{ft}$ is 38.2 feet. The upper lock gate is used to supplement the bottompllling system for the 1200-foot and 800-poot ohambers. For the 400-100t chamber the bottom fllling system is connected to an intake manifold in the downetream half of the 800-foot chamber. Emptying syatem conslats of stub culverts discharging into elther the open river or the tallbay. Extensive tests were made on the land wall emptylng syetem to ellminate low pressures downstream from the valve. Flling tests were run in the 1200-foot and 800-foot chambers to coordinate operations of the culvert valves and the talnter service gate.

(h) Des1gn and construction of the model have been completed. The test1ng program is in progrese.

(197) MISSISSIPPI RIVER, FILLING AND EMPTYING BYSTEMS FOR AUXILIARY LOCKS.

(b) 8t. Pqul, M1nnesota, D1strict, Corpe of Engineers, War Dopt.

(o) Corpe of Englneers' atafe.

(e) Design projeot.

(f) To obtain date for use in the design of the flling and emptying systems for the unflnished auxillary locks under a range of heade for ejeteme composed of a single wall oulvert and floor laterals of varlous dimensions, number, and spacing. It 18 antlclpated that the results will be of such scope as to be applicable also to the design of locks in other navigation projects.

(g) Teste were made in a $1: 25$ scale model slmulating a lock 110 feet wide and 360 reet long, usable almensions. The culvert system, from the intakes to a section about 127 feet downstrean from the miter gate p1ntles, simulated a representative design of the syotems used in the 20 existing auxillary locks.

(b) The draft of the rinal report has been completed. Publication bas been ouspended Indefinltely due to curtallment of funds.

(198) MISSISSIPPI RIVER, FILLING AND EMPTYING SYSTEM FOR LOCK NO. 27, ST. LOUIS, MISSOURI.

(b) Upper M1881881pp1 Valley Div181on, Corpe of Eng1neers, War Dept., St. Lou16, Mo.

(c) Corps of Eng1neers' staff.

(e) Design project.

(1) To check the design of the proposed flling and emptying systems for Lock No. 27, and to 1nvest1gate current conditions in the upstream and downstream lock entrances.

(g) After tests were completed on models of the main and auxillary locks, design lengths were changed from 600 feet to 1200 feet for the main lock and from

360 peet to 600 feet for the aux1llary lock. Another model was bullt to the scale of 1:25 to olmulate the 1200-foot maln lock, but the rev1sed design for the aur1liary lock was made wlthout purther model study. The slae flling system for the 1200-foot maln lock was supplemented by flow over a vertical-11ft gate installed at the upper lock gate, and longltudinal culverts of the slde-emptying system were supplemented by a stub culvert at the lower gate. Fllling tests were made to coordinate the operations of the vertlcal-lift gate and culvert valves and emptylng teste were made with different outlet arrangements to reduce turbulence and currents in the tallbay.

(b) Test have been completed. The elnal report 18 belng prepared. 
U. S. WAR DEPT., CORPS OF ENGINEERS, U. S. WATERWAYS EXPERIMENT STATION, V1cksburg, M1s8.

Inquirles concerning Projects No. 199 to 259, 1ncl, should be addressed to The Director, U. S. Waterways Experiment Stat1on, P. O. Box 631, Vicksburg, M188.

(199) (1339) MODEL STUDY OF STILLING BASIN, BLUESTONE DAM, NEW RIVER, WEST VIRGINIA.

(b) The District Englneer, U. S. Englneer Office, Huntington, W. Va.

(c) Personnel of the U. S. Waterways Experiment strtion.

(e) Experimental, for design of stilling basin.

(f) To determine the location of cavitation pockets around the baffle plers, and to develop moderate reviolons in the present stlling-basin design in an attempt to reduce cavitation action.

(8) Bluestone Dam, on New Rlver near Hinton, Wa. Va., w1l be a plood-control and hydroelectrlc power dam. Flow w1ll be regulated by 8 slulces through the sp1llway; 21 vertioal-lift gates surmounting the sp1liway w1Il control extreme floods. The splllway 18 deslgned to pass 430,000 cfs under a head of 30 feet. A secondary or at1lling welr wlll be placed 364 ft downstream from the axis of the dam to provide oufficlent tallwater in the stilling basin for formation of a hydraul1c jump. The basin will contaln a 44- 1 t horlzontal apron, two rows of baffle plers, and an end s1ll. The $1: 36$ scale section model reproduced a portion of the aplliway chute, the stilling basin, and the secondary we1r.

(h) All testo have been completed; preparation of final report 18 in progress.

(200) MODEL STUDY OF GATE SLOTS AND CONDUITS, BULL SHOALS DAM, WHITE RIVER, ARKANBAS.

(b) The D1strict Englneer, U. S. Englneer off1ce, Little Rock, Ark.

(c) Perconnel of the U. S. Waterways Experiment Station.

(e) Experimental, for design of gate slots and condults.

(f) To invest1gate areas of probable cavitation at the gate slots and develop the most sat1afactory type of outlet portal whlch will permit spreading of the conduit discharge to obtain best stilling-bagin performance.

(g) Bull Shoals Dam, to be located on the White River in Arkansas, approximately 115 miles north of Little Rock, Ark., and 10 miles west of Mountein Home, 18 one of the main units in the comprehensive plan for flood control in the White River Basin. Bull Shoals Dar wlll be used to control floodo, generate hydroeleotric power, and provide increased low-water plow for navigation. The dam $w 111$ be a 2,349 - ft concrete-gravity atructure w1th an overflow spillway aection located on the rlght $81 d \theta$ of the valley and a non-overplow section located on the left olde which w1ll contain the intakes and penstocks for supplying water to the generating units. The ap1liway has 17 radial crest gates, 40 ft long and $28 \mathrm{ft} \mathrm{hlgh,} \mathrm{and} 18$ designed to pass a discharge of $556,000 \mathrm{cfs}$. Sixteen gate-controlled condulta are provided through the base of the dam in the splliway aection. Two modele were used orlglnaliy in this study: (a) a $1: 6$ - scale model reproducing the gate slots and a portion of the conduit cross-section; and (b) a $1: 25$-acale model reproducing three of the conduits and $2288-p t-w 1 d e$ section of the st1lling basin. In order to determine if the stilling basin developed on the sluice model was eat1sfactory for spll1way flow, however, an additlonal 1:60-ecale section model reproducing 180 it of the splliway was constructed.

(h) All tests have been completed; preparation of ilnal report 18 in progres8.

(201) MODEL STUDIES UF SPILLFAY, STILLING BASIN, AND SLUICE, CONEMAUGH DAM, CONEMAUGH RIVER, PENNSYLVANIA.

(b) The District Engineer, U. S. Englneer off1ce, Pittaburgh, Pa.

(c) Perconnel of the U. S. Watemay s Experiment Station.

(e) Experimental, for design of splllway, stilling basin, and aluice.

(P) To determine a suitable design for st1lling facllities below the spillway, 
shape of crest, and allied features, and to develop an adequate design for the condults.

(g) The Conemaugh Dam, to be located on the Conemaugh River in Indiana and Westmoreland Count18s, Pennsylvania, gbout 7.5 miles above the junction of the Conemaugh R1ver and Loyalhanna Creek at Saltsburg, Pennsylvan1a, w1ll be one of the main units in the comprehensive plan for flood control in the P1ttsburgh D1strict. The dam will consist princlpally of a concretegravity section with an earth embankment section at the right abutment. A centrally-located splllway, designed to discharge 370,000 cfa w1ll contain 14 crest gates, each 30 ft by 27 ft hlgh. Normal flow will be regulated by condults through the splllway. Two models were used orlginalig in this study: (I) a $1: 60-$ soale comprehensive model, reproducing the entire problem area inoluding about 1000 ft of approach channel, the entire dam, and about 1500 it of exit channel below the dam; and (2) a $1: 24$ scale section model was used to study the best design of each type st1lling basin produced by tests conducted on the comprehensive model. In order to make a more complete study of sluice action, a $1: 15$-scale model of one of the sluloes was reproduoed to select the most favorable invert elevation, intake and trash-rack design, and outlet design.

(h) All tests heve been completed; preparation of final report 18 in progress.

(202) MODEL STUDY OF BTILIING BASIN, CLARK HILL DAM, SAVANNAH RIVER, GEORGIA.

(b) The Division Eng1neer, Boutb Stlant1c D1vis1on, Atlanta, Ga.

(c) Personnel oi the U. S. Haterways Experiment station.

(e) Experimental, for design of stilling beein.

(f) The general purpose of the model study was to examine the hydraulic performance of the bucket as orlglnaly designed. In this connection data wore desired as to the effect of varying the tallwater irom the theoretical depth required for a hydraul1c jump over a horizontal apron to a depth 20 percent in excess of the theoretieal jump depth.

(g) The Clark H1ll Dam 18 proposed for construction on the Savannah R1ver about 20 miles north of Augusta, Ga. The dam w11l be a combined earth and concrete structure w1 th a top elevation of 351 ft and a length of about 5660 it. An ogee-type splllway near the center portion of the concrete dam has a gross length of $1096 \mathrm{ft}$ and 18 designed to pass a maximum plow of $1,058,000$ cPB under a head of $46 \mathrm{ft}$. Flow over the sp1llway $111 \mathrm{l}$ be controlled by 23 tainter gates, each $40 \mathrm{ft}$ w1de and $35 \mathrm{ft}$ high. The energy dissipater at the toe of the splilway w1ll be of the bucket type with a radius of 50 it and a lip height of $14.6 \mathrm{ft}$. Provisions also are being made for the reloase of flow through slulces located in the splllway section and for generation of hydraul1c power. The 50-ft-radius bucket of the clark Hill Dam splilway was installed at the toe of the existing models of stewarts Ferry Dam and Conemaugh Dar. This permitted comparison of results obtalned Prom a 1:100-scale section model and from a $1: 35$-scale section model. No alterations were made to the existing crest shape and gates of the section models. The total discharge over the ap1llagy and through the bucket was proportioned to scale in both models, and simulated the discharge per foot of wath thet would exist for the Clark H1ll Dam conditions.

(h) All tests have been completed; preparation of flnal report is in progress.

(203) (1341) MODEL EVALUATION OF CAVITATION ACTTON, CLAYTOR DAM, NEW RIVER, VIRGINIA.

(b) The D18trict Engineer, U. S. Engineer Office, Huntington, $W . V a$.

(c) Personnel of the U. S. Haterways Experiment station.

(e) Experidental, for design.

(P) To evaluate the pressure variations on the baffle plers of the Claytor Dam; the results of these tests are to be used as a basis for evaluating the possibli1ty of dangerous erosion by cavitation of the Bluestone Dam baffle plers (see Project No. 199, "Model study of stiling basin, Bluestone Dam, New RIver, West Virginia").

(g) Clsytor Hycioelectrio Project 18 located on New River near All1sonia, Virginia. In addition to the regulation of flow for power development, plow is passed through two outlets located in the splilway and controlied 
by 5-1t gate valves. N1ne splllway gates are used to control extreme rloods. Maxmum flow over the splllway occurred dur1ng the llood of August 13-16, 1940, when a discharge of 200,000 cls was passed orer a head of $28.5 \mathrm{ft}$. The st1lling arrangement below the splllway conslsts of a short apron with a row of baffle plers and an end sill. The 1:36-scale section model reproducod 5 central bays of the splilway and stilling basin.

(h) All tests have been completed; preparation of flnal report is in progress. (To be 1ncorporated in report, "Model study of st1lling basin, Bluestone Dam, New River, Host Virg1nia".)

(204) MODEL STUDY OF DEMOPOLIS LOCK AND DAM, TOMBIGBEE RIVER, ALABAMA.

(b) The D1strict Englneer, U. S. Englneer offleo, Mob1le, Ala.

(c) Personnel of the U. S. Waterways Experiment Station.

(o) Experimental, for design.

(1) To determine scouring action and flow charecteristics below the st1lling apron and at the lock entrances, and to devise corrective measures or 1mprovements which may be indicated.

(g) The Demopol1s Look and Dam w1Il be bullt at a 81 te about 2 m1les below Demopol1s, Ala., on the Tombigbes R1ver, and 3 miles below the existing Lock No. 4, which 1 t w1II replace. It w1ll be concrete gravity section, w1th a splilway extending the entire length of the dam. A single lock on the left bank end of the spillway will be provided for navigation purposes. A 1:80-scale comprehensive model reproduces $2300 \mathrm{ft}$ of approach area and 2500 ft of ex1t channel, the full w1dth of the channel and overplow area, the sp1llway, st1lilng basin, and locks. A 1:40-scale section model of the splilway reproduces a 40-It section of the sp1llway and st11ling basin and a portion of the exit channel.

(h) All tests have been coepleted; preparation of final report is in progress.

(205) MODEL STUDY OF SPILLWAY AND CONDUITS, DETROIT DAM, NORTH SANTIAM RIVER, OREGON.

(b) The Distriot Englneer, U. S. Englneer Offlce, Portland, Ore.

(c) Personnel of the U. S. Waterways Experiment station.

(e) Experimental, for design of spillway and condults.

(1) To analyze the hydraul10 characterist1os of the spiliway and otilling basin, and the llood-control condults; and to develop means of correcting any uneconomle, unsafe, or otherwise undeslrable conditions whlch may exist in the proposed design of these structures.

(8) Detro1t Dam, to be located near Detro1t, Ore., 18 one of seven mult1ple-use dams to be bullt on the ma1n tributaries of the W1llamette R1ver. Detro1t Dam w1l operate in parallel with the other dams to reduce flood helghts on the main stream, to propide increased low-water flow for nav1gation or 1rr1gatlon, and to generate hydroelectric power. An ogee-type eplllway near the center portion of the 1580-ft concrete dam 18 deslgned to pass a maximum flow of 157,000 ofs at a head of $30.4 \mathrm{ft}$. OrIg1naliy, four 64-ft-vide by 28-ft-hlgh radial orest gateg were deslgned to oontrol extremo ploods. However, latest plans call for 6 gates, $42-\mathrm{ft}$ wide by $28-1 \mathrm{t}$ hlgh. Revlsed. plans also call for two 72-1noh clroular condults at elovation 1265 controlled by 72-1nch hollow jet valves located approximetely 42 ft lrom the upstream face discharging Into free flowing condults loading to the downstream lace of the dam, and 1 iz 5-1t-8-1nch by 10-1t-0-1nch rectangular condulte, three at elevation 1340 and three at elevation 1391, controlled by hydraulically-operated sllde gates discharging at the downstresm face of the dam. Three 15-1t-0-1nch diameter penstocks located to the right of the sp11lway w1Il conduct Ilow to the power turbines. Two models are 1nvolved In thls gtudy: (I) a $1: 60-8 c a l e$ general model reproducing the splliway and ot1lling basin, the dam, the 5 flood-control condults, and the power structures; and (2) a 1:15-80ale model of the flood-control condults.

(h) The splliway tests are in progress; the model of the condu1t 18 under construction.

(206) MODEL STUDY OF SPILLWAY, DILLON DAM, LICKING RIVER, OHIO.

(b) The Distriot Engineer, U. B. Engineer Office, Huntington, Fa. 
(c) Personnel of the U. 9. Waterways Experiment station.

(e) Experimental, for design of splilway.

(f) To determine (a) extent and magnitude of any destructive eddies whloh may be formed near the toe of the dam when the splllway $1 \mathrm{~s}$ in use and to derise correctlve measures therefor; and (b) whether the ogee-type splllway w1th 1ts deeper channel w1ll provide better performance over the less expensive plan of using a broad-crested spillway.

(g) Dillon Dam, to be located on Licking RIver, Oh10, w1ll bo a rolled earthfliled structure with an uncontrolled splilway loceted in the left abutment. Controlled Plow regulation w1ll be provided by an outlet works located in the right abutment. The outlet works, w1th a capac1ty of 7000 cps at conservation pool level, w1ll cons1st of a three-gated intake (each gate 7 ft w1de by 15 it h1gh), a 551-ft horseshoe-shaped condu1t, and a st1lling bas1n. A 1:50-8cale model reproduces $1000 \mathrm{ft}$ of the approach area and 1800 ft of exit channel, the full width of the dam and sp1llway area and the controlling condult with gates and st1lling basin.

(b) Testing 18 in progress.

(207) MODEL STUDY OF SLUICEB, FALL RIVER DAM, FALL RIVER, KANSAB.

(b) The D1strict Englneer, U. S. Englneer Off1ce, Tulsa, Okla.

(o) Personnel of the U. S. Waterways Experiment station.

(e) Experimental, for design of slu1ces.

(f) (a) To determine the adequacy of the present slulce design; (b) to determine whether art1f1clal means of spreading the flow as 1t emerges from the slu1ces 18 necessary; and $(c)$ to develop the most sultable design for the slulces.

(g) The dam consists of an earth-1111 embankment spanning the valley w1th a concrete splilway otructure in the river channel near the right abutment. The sp1llway 18 of the gravity, ogee-we1r type with e1ght 50-ft by 25-It high tainter crest gates. Normal flow regulation 18 afforded by seven 5-ft by 8-pt-6-1nch slu1ces through the splliway welr, one along the centerline of each of the splliway plers. A 1:20-8cale sluice model reproduces a port1on of the pool area, three slulces, a 256-ft wlde section of the st1ling basin and 200 ft of the exit channel.

(h) All tests have been completed; preparation of the final report is in progress.

(208) MODEL STUDY OF SPILLWAY, ENID DAM, YOCONA RIVER, MISSISSIPPI.

(b) The President, M1881881pp1 R1ver Comm1s810n, V1cksburg, M188.

(c) Personnel of the U. 8. Waterways Experiment Station.

(e) Experimental, for design.

(f) To examine the hydraulic performance of the proposed comblned structure w1th especial reference to the capacity, hydraul1c safety, and effect of the sloping side walls on the hydraulic performance of the structure.

(g) En1d Reservolr, one of several flood-control works planned to furnish flood protection to the Yazoo R1ver Bas1n above the head of the M1881881pp1 River backwater area, will be located approximately 3 mlles north of Enld, M1sa. The proposed dam 18 an earth-P1ll structure w1th an uncontrolled chute-typo splilway having a crest length of 200 Pt and designed to pass a flow of 49,700 ofs under a head of 16 ft. Flow regulations w1ll be afforded by condults through the splilway sectlon. An unusual feature of thls dam wll be the plat slope of the concrete olde walls extending the full length of the eplliway; the flat olope is necessary since the walls are designed to be constructed of concrete with no relnforcing steel. The 1:30-8cale model reproduces about $450 \mathrm{ft}$ of approach channel, the sp1llway, the intake tower and condults (schematically), and about 450 ft of the exit ohannel.

(h) All tests bave been completed; preparation of flnal report 18 in progress.

(209) MODEL STUDY OF SLUICES, FORT GIBSON DAM, GRAND (NEOSHO) RIVER, ORLAHOMA.

(b) The District Englneer, U. S. Englneer Offlce, Tulsa, Okla.

(o) Personnel of the U. 8. Waterways Experiment Stat1on.

(e) Experimental, for design of slulces. 
(1) To determine the adequacy of the proposed sluice designs.

(g) Fort Glbson Reservo1r, to be located on the Grand (Heosho) R1ver, Okla., w1ll be used for the dual purpose of flood control and development of hydroelectric power. The dam will be a concrete-gravity type structure with an overall length of approximately $2850 \mathrm{ft}$. A 1490-1t concrete ogee-type sp1Ilway, located within the dam section, 18 designed to pass 919,000 ofs at a head of approximately $35 \mathrm{ft}$. The splliway discharge w1ll be controlled by th1rty 40-pt talnter gates surmount1ng the sp1liway crest. Normal plow regulation 1s afforded by ten 5-ft-8-1nch by 7-ft slulcea through the sp1llway proper. a 1:20-8cale model reproducing a portion of the pool area, five slulces, a 256-ft-wide section of the at1ling basin, and 200 ft of the exit ohannel.

(h) All tests have been completed; preparation of f1nal report is in progress.

(210) MODEL STUDY OF INTAEE STRUCTURES, GARRISON DAM, MISSOURI RIVER, MORTH DAKOTA。

(b) The District Englneer, U. S. Englneer Offlce, B1smarck, N. D.

(c) Personnel of the U.S. Waterways Experiment station.

(e) Experimental, for design of intake structures.

(P) To develop the most sultable intake design by (a) vacuum tests to determine location of critical areas which light be subjooted to cavitation pressures; and (b) tests under atmospheric pressures to determine head losses through the intake.

(g) Garrison Dam w11l cons1st of an earth eabankment ris1ng approximately 185 ft above the valley of the Missourl River upatream from Blsmarok, N. D. Elght power condults and five flood-control slulces will be located in the right abutment. A chute-type splliway in the left abutment w11l be deslgned to pass a plood plow of $600,000 \mathrm{cPs}$. The study $1 \mathrm{~s}$ belng conducted on 2 model, scale of 1:30, reproducing a portion of the intake structure and one sluice including the intake throat, trash-rack, bulkhead, emergenoy and servioe gate slots, one serv1co gate, alr vent, and transition seotion.

(h) Testing 18 in progress.

(211) MODEL STUDY OF OUTLET STRUCTURES, GARRISON DAM, MISSOURI RIVER, NORTH DAKOTA.

(b) The District Englneer, U. S. Engineer Offlce, B1smarck, N. D.

(c) Personnel of the U. 3. Waterways Experiment Station.

(e) Experimental, for design of outlet structures.

(I) To develop a st1lling device for the power conduits, whloh w1ll be used for divergion during construction of the dam. that can later be inoorporated into the powerhouse substructure, and to develop a slulceway st1lling basin.

(g) Garrison Dam w11l cons1st of an earth embankment rising approximately 185 ft above the valley of the M1ssour1 River upstream from B1smarck, N. D. E1ght power condult and five flood-control sluices w11l be located in the right abutment. A chute-type splllway in the left abutment will be designed to pass plood flow of 600,000 c 18 . The study 18 belng conducted upon a model, soale of 1:45, reproducing about $300 \mathrm{ft}$ of the lower portion of the power condults and slulceways, the entire tailrace area and stilling basin below the slulceway, and about $1000 \mathrm{ft}$ of the exit area below the stilling basin.

(h) Testing is in progress.

(212) MODEL STUDY OF HARLAN COUNTY DAM, REPUBLICAN RIVER, NEBRASKA。

(b) The D1strict Eng1neer, U. S. Englneer Of11ce, Kansas C1ty, Mo.

(c) Personnel of the U. 8. Waterways Experiment station.

(e) Experimental, for des1gn.

(f) To study possible erosive currents along the left training wall and eddy action along the toe of the dam.

(g) The dam cons1sts of a rolled-f111 embankment section and a gravity-type concrete overflow structure 1ncluding the gate-controlled eplliway, the Plood-control outlet works, Irrigation outlets, bulkhead section to epfect connections w1th the earth embankment, and provision for Puture power 1nstallation. The sp1llway, $876 \mathrm{ft}$ in width, 1 a controlied by 18 crest gates, each $30 \mathrm{ft}$ high by $40 \mathrm{ft}$ w1de. The splllway structure 1ncludes 10 slulces, 
each 5 ft wide and $8 \mathrm{ft}$ high. The 1:80-scale model reproduces about 2,000 ft of approach channel, the splliway, the sluices, the st1lling basin, and about 4,400 ft of the exit channel.

(b) All tests have been completed; preparation of final report is in progress.

(213) MODEL STUDY OF CONTROL STRUCTURE, MORGANZA FLOODWA, LOUISIANA.

(b) The President, M1s818s1pp1 R1ver Commission, V1cksburg, M1ss.

(c) Personnel of the U. S. Waterways Experiment Station.

(e) Experimental, for design of control struoture.

(P) To determine discharge coefflcients and to investigate head-discharge relatlonships, effect of stllling-basin design on the hydraulic jump, and effect of orest shape on hydraulic efflciency.

(g) Morganze Floodway Control Structure w1ll cons1st of an ogee-type spillway and a stilling basin, the design of which will be governed by the results of model tests. 191 gatebays, each $23 \mathrm{ft}$ w1de, w1ll control flood plows through the Morganza Floodway. The 1:16-scale model w1ll reproduce about 250 ft of approach area and 500 ft of exit area, the plve gate bays on the right end of the structure, and a portion of the right training wall.

(b) Design of model is in progrese.

(214) MODEL STUDY OF SPILLFAY AND STILLING BASIN, OSCEOLA DAM, OSAGE RIVER, MISSOURI.

(b) The District Engineer, U. S. Englneer Office, Kansas City, Mo.

(c) Personnel of the U. 8. Waterways Experiment station.

(e) Experimental, for design of splllway and stilling basin.

(f) To confirm design assumptions and to arrive at the most feasible and economical stilling-basin design.

(g) The dam consists of a rolled-fill earth embankment section and a gravitytype concrete overflow structure including the gate-controlled spillway, the flood-control and navigation condults, bulkhead seotions to epfeot connection with the earth embankment, and provision for future power installation. The spiliway $18760 \mathrm{ft}$ in width and $1 \mathrm{~s}$ controlled by 16 crest gates (each $30 \mathrm{pt}$ high and $40 \mathrm{ft}$ wide). The splllway structure includes 15 slulces (each $5 \mathrm{ft}$ wide and $8 \mathrm{ft}$ high). The 1:60-scale model reproduces about $900 \mathrm{ft}$ of approach channel, the splliway, the sluices, the stilling basin, and about 1500 it of the exit channel.

(h) Testing is in progress.

(215) MODEL STUDY OF SPILLWAY, STEWARTS FERRY DAM, STONES RIVER, TENNESSEE.

(b) The D1strict Engineer, U. S. Englneer Office, Nashville, Tenn.

(c) Personnel of the U. S. Waterways Experiment station.

(e) Experimental, for design of spillway and st1lling basin.

(f) To analyze the hydraulic characterlstios of the splliway and the stilling basin and to develop means of correcting any uneconomic, unsafe, or otherwise undesirable conditions winlch may exist in the proposed design.

(g) The dam is a composite-type structure consisting of rolled-fill earth embankment sections and of a gravity-type concrete section containing the splilway and powerhouge intakes. The 328-1t splliway containing 7 crest gates (each $26 \mathrm{ft}$ high and $40 \mathrm{ft}$ wide) 18 designed to pass a maximum discharge of $199,000 \mathrm{cfs}$ under a head of 32.5 ft. Low flows w1ll be regulated by 5 sluices (each $10 \mathrm{ft}$ high and $5 \mathrm{ft} 8$ inches wide) through the splllway section. A bucket-type stilling basin will dissipate tice energy contained In the splilway flow. A 1:80-8cale model reproduces about 1,400 ft of approach channel, the splilway, the slulces, the bucket-tyne energy dissipator, a portion of the dam, and about $2,200 \mathrm{ft}$ of exit channel.

(h) All teste have been completed; preparation of final report is in progress.

(216) MODEL STUDY OF IRRIGATION TUNNEL, ST. MARY DAM, SASKATCHEWAN, CANADA.

(b) The Chlef Engineer, Prairie Farm Rehabilitation, Dept.of Agriculture, Saskatchewan, Canada. 
(o) Personnel of the U. S. Waterway Experiment station.

(e) Experimental, for design.

(1) To oheok the hydraul10 oharacterist108 of the 1rrigation tunnel and to develop means for correcting any uneconomic, unsafe, or undesirable cond1t1ons whlch are found to exist in the proposed design.

(g) St. Mary Dam 18 to be a unit in the St. Mary-M1lk Rivers Project, by which It 18 proposed to develop some 345,000 acres of 1rrigated land in adition to provialng a better water supply for existing irrigation districts comprlalng some 120,000 acres. A rolled 111 dam with a orest length of about 2,400 seet w11l rise 190 feet above the valley floor. A cut through the sumit of a ridge w1ll serve as a splllway and will conduct flood flow to a coulee roughly paralleling the river to the north. A tunnel through the hill to the south of the dam w1ll conduct irrigation water Prom the reservo1r. This tunnel has been designed to pass a maximum discharge of 3,200 cfs w1th the head varying from a minimum of 25 feet to a maximum of gi feet. A 1:25-8cale model w1Il reproduce approximately 200 feet of approach channel, the Intake structure, incluaing the service gates, transition prom the intake to tunnel, the tunnel, the outlet transition, and about 300 feet of exit channel.

(b) Construction of the model is in progress.

(217) MODE STUDY OF SPILLWAY AND BUCKET IN SECTION, WHITNEY DAM, BRAZOS RIVER, TEXAS.

(b) The District Englneer, U. S. Englneer Offloe, Galveston, Tex.

(c) Personnel of the U. S. Waterways Experiment Station.

(e) Experimental, for design of splliway and bucket.

(P) To analyze the hyaraulic characterlstics of the splliway and stilling basin, and to develop means of correcting any uneconomic, unsafe, or otherwise undesirable conditions whlch may exist in the proposed design.

(g) The dam as proposed cons18ts of an 824-1t ogee-type sp1llway near the center portion of the 1680-1t conorete structure designed to pass a maximum floy of 660,000 cfs at a head of $40 \mathrm{ft}$. The splilway contains 17 tainter gates (each $38 \mathrm{ft}$ hlgh by $40 \mathrm{ft}$ wide) and 16 flod-control oondults (each 9 Pt klgh by 5 it wide). A 200-pt horizontal stilling basin with baffle plers and end s111 w111 d1881pate the energy contalned in splliway flow. A $1: 30$-scale section model reproduces one entire bay of the splliway and two adjacent half bays, $a$ portion of the approach channel, the bucket or horlzontal apron, three sluices, and a portion of the exit channel.

(h) Testing 18 in progress.

(218) MODEL STUDY OF CONDUIT ENTRANCES.

(b) Offlce, Chlef of Englneers, U. 8. Army, Washington, D.C.

(c) Personnel of the U. S. Watemays Experiment Station.

(e) Experimental, for design of oondult entrances.

(1) To collect experimental data on which to base the hydraulic design of condult entrances for condult alignments at varlous angles to the upatream face of a dam.

(g) Models, 1:20-bcale, of s1x intakes for a 5-1t-8-1nch by 10-1t-0-1noh condu1t were fabricated of plastic and attached to a seel pressure tank for testing. The intakes tested vere for oondult alignments normal to the face of the dam and at angles of 10, 20, 30, and 40 degrees from the normal to the face of the dam.

(h) All tests have been completed; preparation of 11 insl report is in progres..

(219) MODEU STUDY OF SLUICE GATES.

(b) opflce, Chlef of Eng1neers, U. S. Arny, Washington, D. C.

(c) Personnel of the U. S. Waterways Experiment Station.

(e) Experimental, for design of sluice gates.

(f) To determine the best shape gate ilp to reducs the downward hydraulio pull on 
the gates and any vibration tendencles during the opening or closing procedure.

(g) A 1:6-scale model w1ll reproduce the gate slots, the sluloe gate, a portion of the condult upstreas and downstream from the gate section, and the alr vents.

(h) Testing 18 in progress.

(220) MODEL STUDY OF SUCTION HEAD, DREDGE JADWIN.

(b) The District Eng1neer, U. S. Englneer Offlce, Memphis, Tenn.

(c) Personnel of the U. S. Waterways Experiment Station.

(e) Experimental, for design of dredge suction heads.

(f) To Invest1gate the design of the now types of suction heads, and to obtain data and information on the operation of the old and new types of heads whloh w1ll ald in Improving the deslgn and offlolency of a new suction head.

(g) The model reproduces dredging operations using a bed of sand which may be var1ed to correspond to pre-maintenanoe and maintenance dredging conditions. Comparison tests are also being made using clear water. The model 18 conetructed undistorted to the linear scale rat1o, model to prototype, of 1:10. The model consists of a plume with a sand bed spanned by a movable carrlage supporting a suction head and pumps. The discharge from the suction line is spolled into a settling basin where the rate of flow and percent of sol1de can be measured.

(h) All tests heve been completed; preparation of flnal report is in progress.

(221) PROTOTYPE CONFIRMATION OF MODEL STUDIES.

(b) The Director, U. S. Watemays Experiment Station, V1cksburg, M1ss.

(c) Personnel of the U. B. Waterwayg Experiment station.

(e) General information.

(1) To obta1n, from already accumulated data and from future prototype observations, material to be analyzed and tabulated for subsequent interpretations. The ultimate aim of the investigation 18 to ald the engineer in evaluating results obtalned from small-s120 studiss, as well as to advance the sclence of model investigations.

(g) Inquirles have been addressed to departmental opfloes enlisting thelr cooperation in furnishing baokground materlal such a plang and spec1p10ations, construction progress photographs, construction status, changes in design, and any measured prototype performance data. In the case of projeots in the fingl stages of construction and for which no means of obta1nIng hydraul1c data have been provlded, plans have been made for procuring such data as is possible. For projects whlch have been recently inltiated, the faaslb1l1ty for prototype measurements w1ll be determined, and plans formulated for the installation of equipment for making hydraulic observat1ons.

(a) Prototype data are being obtalned.

(222) MODEL STUDY OF PONTONS FOR THE M5 BRIDGE.

(b) The Executive Offlcer, the Englneer Board, Fort Belvo1r, Va.

(c) Personnel of the U. S. Waterways Experiment station.

(e) Experimental, for design.

(f) To study the effect of adding the reotangular center section to the $\mathrm{M} 4$ pontons in the M5 bridge; to secure data on the M4 pontons in the M5 bridge; and, if possible, to improve the freoboard in high velocity flow by testing several new type bou shapes.

(g) The 44 ponton $1 \mathrm{~g} 6$ ft 10-1/2 1nches w1de and 29 ft 7-5/8 1nches long, w1th a curved streamlined bow and rectangular-shaped stern. When used in an M4 type bridge, two pontons are fastened stern to stern and adjacent palrs of pontons placed at 15- ft centers. W1th the M5 bridge, however, a rectangularshaped center section is added to the two pontons forming an overall length of about $81 \mathrm{ft}$. The 8l-1t overall sectlons are spaced at $7.5 \mathrm{ft}$ center to center. The models of the pontons and the 15 bridge are constructed to the 
Inear-8cale rat1o of 1:15. The deck of the M5 bridge 16 reproduced by a wooden frame of such construction as to reproduce the deflection character$18 t 1 \mathrm{cs}$ of the prototype bridge under load.

(h) All tests have been completed; preparation of the Inal report 1 s in progres8.

(223) MODEL STUDY OF HYDRAULIC SYSTEM, NEW JERSEY SHIP CANAL LOCKS, NEW JERSEY.

(b) The Distrlct Englneer, U. S. Englneer Opflce, New York, N.Y.

(c) Personnel of the U. S. Waterway Experiaent Station.

(e) Experimental, for design of hydraulic system.

(f) To test the hydraulic system of the ship look, and to make a navigability test to determine the effect of the contemplated top filling system upon vessels using the sayreville locks.

(g) The New Jersey Bhlp Lock 18 one of threo locks proposed for the Bayreville end of the New Jersey Ship Canal. The overall length of the sh1p lock as proposed is $960 \mathrm{ft}$ with a width of $90 \mathrm{ft}$. The Bhlp lock $1 \mathrm{~s}$ to have two intermedate sets of gatee, affording ohabers with overall length of 350 , $430,530,610$, and 960 ft and usable lengths of $270,350,450,530$, and 880 ft. Th1 lock is to have an emprying system comprised of a side culvert 21 ft 3 in. by 21 ft 3 in. w1th 22 laterals located in the bottom of the lock chamber, and pliling system consisting op two slde culverts 15 ft by $15 \mathrm{ft}$ with 90 (45 to the culvert) top fllling ports. The maximum lift of the ahlp locke is $10 \mathrm{ft}$. A 1:20-8cale model reproduced the shlp lock and a small portion of the lower and upper pools. This lock was bullt w1th all appurtenances for pllling and empty1ng, inoluding the tainter gates in both systems operating w1th respect to thelr prototype t1me interval.

(b) All tests have been completed.

(224) (1150) HYDROLOGICAL RESEARCH PROJECT, EXPERIMENT STATION, LAEE WATERSHED, MISSISSIPPI.

(b) Offlce, Chlef of Engineers, U. S. Army, Washington, D. C.

(o) Personnel of the U. S. Waterways Experiment station.

(e) General 1nformation.

(1) To augment pertinent data and to advance the knowledge of the hydrological characterlatics of any dralnage basin through a comprehensive study of the hydrology of a typical small watershed -- that of the Experiment station Lake.

(g) The Experiment station dam forms a small lake whose elevation 18 controlled by a chute-type spillway. Pertinent pacts concerning the watershed are: shepe, oval; area, 3,521 acres; terra1n, rough and h1lly; so11, loess; vegetation, pasture, cultivated land, woods; habltation, scattered. Tro investlgations are included in the project: (1) a study of the rainfali-runoff relation using the unit-hyorograph method; and (2) a study of evaporation. The apparatus and structures used in the project cons1st of: 29 nonrecording and 5 recording rain-gaging stations located at approximately half-m1le Intervals over the watershed; 6 inflow stream-gaglng atations; two land and one ploating evaporation station; six ground-water wells; and two type $B$ and two type FA infiltrometers.

(h) Study discontinued.

(225) POTAMOLOGY STUDY.

(b) The President, M1881881pp1 R1ver Comm1ssion, V1cksburg, Miso.

(c) Personnel of the U. S. Waterways Experiment station.

(e) Experimental, for general information.

(f) To obtain quel1tative information from laboratory strears baving no direct scale relationship to any stream in nature: (a) fundamentals of meandering phenomena; (b) effect of bank etabllization on simplo meandering streams cons1sting of a ser1es of nearly uniform bends; (c) efpect of bank stabll1zation on laboratory atreams having the alignment of cortain reaches of tho M1981881pp1 R1ver; and $(d)$ to conduct a study toward malsing true erodible bank models that w1Il reproduce bank line changes in the riter to the end that spec1f10 bank etab1lization problems may be studiod in the laboratory to Indicate when and where stabllization works should be placed. 
(8) The project has been established to obtain qualitative information on the meandering phenomena of the M1ssissippl River and to learn the effects of revetments and dikes on the regimen of the river. Laborators meandering streams are developed in movable bed and erodible bank material. The early tests were conducted w1th a atralght channel, having a curved entrance. Later tests were conducted with the inltial ohannel having slight sinuosity throughout. The third series of tests is being conducted with the initial channel having the alignment of the river, and the fourth series of tests is being conducted with the stream molded to a depinite scale relationship with the river. The data obtained during all tests consist of gage readings, hydrographic surveys, water-surface and bed proflles, photographs, and observations of bed load movement.

(h) A detalled description of the model tests and results is contained in the inal report, "Laboratory study of the meandering of alluvial rivera", Nay 1, 1945, ava1lable on loan.

(226) MODEL STUDY OF INVESTIGATIONS FOR THE CONTROL OF BANK CAVING AND MEANDERING OF ALLUVIAL STREAMS.

(b) The President, Misissippl River Commission, Vicksburg, Miss.

(c) Personnel of the U. S. Waterways Experiment Station.

(e) Experimental, for developing model techniques.

(1) To develop a model technique for the study of meandering streams with a view to determining the necessity for and the effects of bank revetment, dredging, and other regulative measures in any troublesome reach and the study of revetment to determine the causes of pallures and the development of means of preventing therf.

(g) Study and development of erodible bank materials and a model operating technique which will result in a model river which responds to the laws of meandering in the same degree as 1 t 8 counterpart in nature and which can be used to indicate the trends in regimen changes in any reach of an alluvial river and the necessity for regulative works for the 1mprovement and stab1lization of the reach. Study of various types of revetment in present use to determine causes of fallures and to develop methods of overcoming them. A flume has been constructed to determine the erodibility factors of various materials which can be used to slmulate bank caving of the prototype and to correlate this material with material of varying degrees of resistance to erosion $a s$ found in the prototype. The flume 181 it wide and $I$ in. deep with a 6 it straight section and a curved section of $5 \mathrm{ft}$ radius. Provislons are made for the molding of erodible material on the outside of the bend. A typlcal unstable bend of the M1881881ppi River will be reproduced in an existing plume and studies will be made to determine scale ratios and allowable distortions which will permit the reproduction of river meandering and bank caving. The information obtained from this study will be used to design a model and model operating technique for the study of a reach involving several bends of the M1ssissippl River. For the study of revetment iallures, it 1 s planned to construct an 8 ft by 3 ft by 6 ft flume in whioh a typical section of the Mis81ssippi River will be molded in an erodible material to an undistorted scale of $1: 50$ and the revetment almulated as nearly as practical to proper scale of mass strength, and dimension. This flume will be used as a preliminary atep in the development of a model technique which will reproduce all forces acting upon revetment in the prototype. In conjunction with the model study, a survey w1ll be made of revetment in the MIB818B1pp1 River to obtain data whioh oan bo correlated with those obtained in the model.

(b) The construction of a flume for the determination of erodibility factors has been completed and testa are in progress. The design of the plume for the revetment study has been completed. An unstable section of the Mississippl River has been selected for the study of river meandering and ohannel atablilation and preparations are being made to start this phase of the study.

(227) MODK STUDY OF FLOOD CONTROL PROJECT, BRADY CREEK, BRADY, TEXAS.

(b) The Distriot Englneer, U. S. Englneer office, Galveaton, Tex.

(c) Personnel of the U.S. Waterways Experiment Btation. 
(e) Experimental, for channel 1mprovementa.

(1) To study, ver1fy, or modify the design assumptions on the capacty of the project or 1mproved channel, water-surface elevations, slopes and velocities.

(g) The clty of Brady, Tex., 1 a located on Brady Creek 29 m1les above the mouth, 173 miles aouthwest of Fort Worth, Tex, and 154 m1les northwest of Austin, Tex. The major portion of the olty of Brady, including the induatrial or bus1nesa district, 18 located on the south bank of the creek. This south bank 1 a comparatively low and 1 s subject to 1nundation by major floods. Protection of this area from floods by 1mproving the channel and constructIng a high lever along the south bank is under consideration. The model 18 of the f1xed-bed type w1th soale rat1os: horlzontal dimenalons, 1:150; vert1cal dimenalons, 1:100. Reproduced in the model are 11,000 it of the Improved channel, approximately 600 It of unimproved channel adjacent to the upatream end of the improved ohannel, and approximately 5700 it of unlmproved channel at the lower end. As the proposed 1mprovementa provide for complete protection of the c1ty, only that portion of the c1ty lying within the leveed flood plain 1 s reproduced.

(h) Teating has been suspended, awalting deolalon of the District Englneer relative to further tosts.

(228) MODEL STUDY OF CHANNEL STABILIZATION, MISSISSIPFI RIVER, CAULK NECK TO GREENVILLE, MI88I88IPPI.

(b) The Distriet Englneer, U. 8. Engineer 0ff1ce, V1ckeburg, M18s.

(c) Bersonnel of the U. 8. Waterways Experiment station.

(e) Experimental, for channel atabilization.

(1) The project ha been eatablished to obtain qualitative information on tho meandering phenomena of the M18818s1pp1 River and to learn the effects of revetments ard dikes on the regimen of the river.

(g) Hodel atudy to obtain qualitative information a to past and puture meandering in this reach of the Missise1ppl River, with a view to developing remedial and preventive measures. The model is of the movable-bed and erodiblebank type with seale rat1os: horizontal dimensions, 1:2000; vertical dimenelons, 1:500. Reproduced in the model are $47 \mathrm{~m} 1108$ of the main channel of the M1881881pp1 River between Caulk Neck Cut-off and Walker Bend. To allow for sufficlent meandering of the channel, the model is constructed in a wide flume. Haydite was selected as bed and bank material for reproducing tho bed and bank movement of the prototype channel. The data obtalned during all tests conalat of gage readings, hydrograph1c aurveys, water-surface and bed prof1les, photographa, and observat1ons of bed-load movement.

(h) study was discontinued.

(229) MODEL STUDY OF THE MI8SISSIPPI RIVER, CAIRO, ILLINOI,, TO COTTONWOOD POINT, MIBSOURI.

(b) The President, M18818alpp1 River Comm1esion, V1ckeburg, M188.

(c) Pereonnel of the U. 8. Watemays Experiment station.

(e) Exporimental, for llood control lmprovemonts.

(1) To deterenine the effect of certain proposed plan for controlling noods on the M1se1861pp1 River.

(g) study of flood-oontrol plans for the M1salasippl R1ver. The model 1a of the 11xed-bed type w1th scale rat1os: horlzontal dimenslons, 1:2000; vertical dimensione, 1:100. Reproduced in the model are the main channel and overbank area of the M1831881pp1 R1ver from Grand Tower, I11., (80 m1lea above Ca1ro, I11.) to Cottonwood Point (134 m110a belov Ca1ro, I11.); the Oh1n R1ver Prom Dam 50 (110 m11es above Ca1ro. III.) to the mouth; the Cumberland River from the vieinity of Ruttawa, $\mathbb{K y}$., (42 miles above the mouth) to the mouth; the Tenneseee River from the poot of Gilbertsv1lie Dam (25 miles above the mouth) to the mouth; the Cache R1ver Bas1n; and the B1rds Po1ntNow Madrid Mloodway.

(h) study auspended for indefinite period. 
(230) MODEL STUDY FOR FLOOD CONTROL, CUMBERLAND, MARYLAND.

(b) The District Engineer, U. S. Engineer Office, Washington, D. C.

(c) Personnel of the U. S. Waterways Experiment Station.

(e) Experimental, for dosign.

(1) To study and develop proposed plans for the complete protection of Cumberland, Ma., from lloods.

(g) Cumberland, Md., 18. s1tuated approximately 120 miles northwest of Washington, D. C., at the confluence of Wills Creek and the North Branch of the Potomac River. These two streams produce a severe flood problem in the violnity of the confluence and along W1lls Creek, the smaller of the two streams. The business district of Cumberland parallels W1lls Creek closely and is subject to overflow from this stream. Channel 1mprovement of W1lls Creek by excavation and paving 1s under consideration, but the extent of such 1mprovement 1s to some degree limited by the backwater of the North Branch of the Potomao River. This can be Improved by downstream channel excavation and removal of some of the present obstructions. The model 18 of the fired-bed type w1th an undietorted I1near scale ratio of 1:60. Reproduced in the model are approximately 1.5 miles of Wills Creek, from 1 ts confluence with the North Branch of the Potomac RIver to above the c1ty limits of Cumberland, $\mathrm{Md}_{\text {, }}$ and 4 miles of the North Branch of the Potomac R1ver (approximately 1 mile above and 3 miles below 1 ts confluence with Wills Creek).

(h) All authorized tests have been completed; Puture tests inderin1te, depending on approval of prototype project report.

(231) MODEL STUDY OF NAVIGATION IMPROVEMENTS, GALOP RAPIDS SECTION, ST. LAWRENCE RIVER, NEW YORK.

(b) The District Englneer, U. S. Eng1neer Opflce, Nen York, N. Y.

(c) Personnel of the U. 8. Waterways Experiment station.

(e) Experimental, for navigation 1mprovements.

(f) (a) To determine the suitab1l1ty of two alternate plans for obtalning a deepwater channel through Galop Rap1ds w1th part1cular reference to the provision of sat1s factory veloc1t1es and alignments and freedom from navigation hazards; (b) to develop Improvements in the proposed plans where necessary; and (c) to determine the optimum order of construction and the proper location of spo1l areas.

(B) Some of the most complex hydraul1c problems of the St. Lawrence R1ver Nav1gat1on and Power Project are found in the Galop Rap1ds Section of the International Rap1ds Reach about 67 m1les above Lake Ontario. The Galop Rap1do form the control for water-surface elevations in Lake Ontarlo. Several alternate plans have been developed for the navigation project in this reach, some Involving a dredged navigation channel through Galop Island, and others involving a dredged navigation channel past Galop Island, combined w1th a hydraulic regulation channel through the 1sland. A specifled maximum veloc1 ty must be provided in the nav1gation channel by the adopted plan, and Lake Ontar10 stages must not vary outslde a certa1n range during construotion or after completion of the project. A plxed-bed model with scales of $1: 400$ horlzontally and 1:80 vertically 18 belng used for this study. The limits of the model extend from Ogdensburg, N. Y., (mile 65 belon Lake Ontar1o) to the vicinity of sparrowbank Point (m1le 74.5 below Lake Ontar10). The problem area is molded in removable blocks to pac1litate the change from one plan to another.

(b) All tests have been completed; preparation of final report is in progress.

(232) (1147) HODEL STUDY FOR ELIMINATION OF SHOALING, VICINITY OF HEAD OF PASSES, MISSISSIPPI RIVER, LOUISIANA.

(b) The District Eng1neer, U. S. Englneer D1strict, New Orleans, La.

(o) Personnel of the U. S. Haterways Experiment Station.

(e) Experimental, for channel 1mprovements.

(1) To study and develop plans for the 1mprovement and maintenance of the deepwater channel from the Head of Passes to the Gulf of Mexico through Southwest Pass. 
(g) The M1881881pp1 River flows into the Gulf of Mexico through several natural outlets, of which only South and Southwest Passes are sultable for deepwater nav1gation. South Pass, the shorter of the two, offers a satisfactory, self-maintalned navigation channel; the greatest diffioulties of navigation by this route are found at the head and foot of the pass during high water. The entrance channel at the head of Southwest Pass, however, requires annual ma1ntenanoe dredg1ng. Tentative plans for the elimination of maintenanoe dredging in this pass were studied. The model was of the movable-bed typo with scale rat10s: horlzontal dimensions, 1:500; vert1oal dimensions, $1: 150$. Reproduced were 7 miles of the M1881881pp1 River above the Head of Pas8e8, all of South and Southwest Passes, and the upper 2 miles of Pas a Loutre and of Cub1ts Gap. Cub1ts Gap and Pas a Loutre could bo regulated to discharge any desired percentage of flow, whlle South and Southwest Passes were controlled by maintalning the water-surface elevation at mean GuIf level at their lower enda. These water-surface elevations were controlled by electrically-operated automatic valves whlch replaced taligates in this model.

(h) All tests have been completed; preparation of final report is in progress.

(233) (793) MODEL STUDY OF CHANNEL IMPROVEMENTS, JOHNSTOWN, PENNSYLVANIA.

(b) The District Englneer, U. S. Englneer off10e, P1ttsburgh, Pa.

(o) Personnel of the U. B. Waterways Experiment Station.

(e) Experimental, for design of channel 1mprovements.

(f) To determine the most economical and effective design for the 1mprovements of the channels of the Conemaugh R1ver, Stony Creek, ond the L1ttle Conemaugh RIver, in the viclnity of Johnstown,Pa., so that floods of the magnitude of that of March 17-18, 1936, would be oarried within banks.

(g) The project consists of the 1mprovement of the channels of the Conemaugh River, Stony Creek, and the Little Conemaugh River, in the vicinity of Johnstown, Pa., for flood-oontrol purposes. The project 1nvolves the widening, deepening, and realigning of the channels, and the construction of retalning walls where necessary to confine flood flows within the ohannels. The model was of the f1xed-bed type w1th scale rat10s: horlzontal dimens10ne, 1:200; vertical dimensions, 1:80; and reproduced 5.8 miles of Stony Creek, 2.6 m1les of the Little Conemaugh River, and 4.7 miles of the Conemaugh River, with sufflelent overbank to include all areas considered in danger of possible flooding.

(h) All tests have been completed; preparation of final report has boen auspended for an inderinite period.

(234) MODEL STUDY OF MENPHIS HARBOR, MEMPHIS, TENHESSEE。

(b) The D1strict Engineer, U. S. Engineer Office, Memph1s, Tenn.

(c) Personnel of the U. S. Waterways Experiment Station.

(e) Experimental, for general information.

(f) To determine the effeots whlch the proposed closure of Tennesseo Chute would have upon flood helghts immediately after construction of the works and also after the conflguration of the main channel has become adjusted to the new hydraul1c cond1tions.

(8) Memph1s Harbor comprises the upper 2 miles of Tennessee Chute, 2 m1les of the M18818g1pp1 River upstream thereprom, and the lowermost 3 m1les of wolf R1ver. Local interests desire 1mprovement of Tennessee Chute to provido additional facilities for Memphis Harbor. The princlpal feature of the proposed 1mprovement plan calls for the construction of a closure dam at the head of Tennesser Chute. The model 18 of the type whlch can be operated alternately as a flxed-bed or movable-bed model. Soale rat1os are: hor 1 zontal dimensions, 1:600; vertical dimensions, 1:150. Reproduced in the model are 23.5 miles of the M1881881ppl R1ver between Redman Point and Cow Island together with all overbank areas subject to overflow. Coal was selected as the model material to reproduce bed movement of the prototype channel.

(h) Design of the model is in progress. 
(235) MODEL STUDY OF SECTIONS OF THE MIDDLE NISSISSIPPI HIVER.

(b) The District Engineer, U. S. Englneer Office, St. Louis, Mo.

(c) Personnel of the U. S. Waterways Experiment Station.

(e) Experimental, for channel stabilization.

(1) To determine the efects of certain proposed plans for the maintenance of navigable depths in the low-water channel of the middle Missiso1ppi River.

(g) Study of channel-stabilization plans for the midale Missiselpp1 River. The model 18 of the plxed-bed type with scale ratios: horlzontal dimensions, 1:2000; vertical dimensions, 1:100. Reproduced in the model are the main channel and overbank area of the Mississippi River from Grand Tower, III., ( 80 miles above Cairo, Ill.) to Cottonwood Point (134 miles below Cáro, I11.); the Ohio River from Dam 50 ( 110 miles above Ca1ro, Ill.) to the mouth; the Cumberland River from the vicinity of Kuttawa, Ky., (42 m1les above the mouth) to the mouth; the Tennessee RIver from the foot of Gllbertsville Dam (25 miles above the mouth) to the mouth; the Cache River Basin; and the Birds Polnt-New Madrid Floodway.

(b) Testing is in progress.

(236) MISSISSIPPI BASIN MODEL.

(b) Office, Chlef of Englneers, U. S. Army, Washington, D. C.

(c) Personnel of the U. S. Waterways Experiment Station.

(e) Experimental, for flood control 1mprovements.

( 1 ) To study coordination of operation problems at mood-control and mult1plem purpose reservo1rs, and to demonstrate by actual trial undesirable conditions which may arlse from misdirected or uncoordinated operation.

(g) Construction and operation of a model of the M18618sippl River watershed Including the Oh10, Tennessee, M1880uri, Arkansas, and Red Rivers and the1r principal tributaries. The model will be built to a horlsontal scale of 1:2000, and a vertical scale of 1:100. All streams in the M18818sippl River tershed on which reservolrs for flood control and multiple purposes are located or contemplated, and all existing and proposed llood-control reservolrs, together with all dams, levees, dikes, floodwalls, and other pertinent works will be reproduced. The model area will be approsimately 200 acres, measuring $4500 \mathrm{ft}$ east and west, and $3900 \mathrm{ft}$ north and south. Water-surface elevations will be recorded at control points by 1500 electrioal gages located over the model. Stream flow wlll be controlled by mechanical measuring equipment electrically operated from the same central control points.

(h) Design of the model is in progress.

(237) (415) MISS $1 S S \perp P P I$ RIVEK FLOOD-CONTROL MODEL.

(b) The President, M1881881pp1 River Commis81on, V1cksburg, M188.

(c) Personnel of the U.S. Waterways Experiment Station.

(e) Experimental, for flood control lmprovements.

(P) To determine the effecte of certain combinations of existing and proposed plans for controlling Ploods on the Lower M18818B1ppl River.

(g) Study of Plood-control plans for the Lower M188188Ipp1 River. The model is of the flxed-bed type with ocale ratios: horizontal dimensions, 1:2000; vert1cal dimensions, 1:100. Reproduced in the model are the ma1n channel of the M1881881pp1 R17er from Helena, Ark., (300 miles below Ca1ro, Ill.) to Donaldeonville, La., (900 miles below Calro, Ill.); the ent1re Atohafalaya Basin as far south as the Gulf of Mexico; and the backwater areas of the Arkansar, White, Yazoo, Ouachita, and Red Rivers.

(h) Testing has been temporarily suspended.

(238) MODEL STUDY OF FLOOD-CONTROL PLANS BELOW THE LATITUDE OF MORGAN CITY, LOUISIANA.

(b) The President, M1881881pp1 River Comm1s810n, V1cksburg, M188.

(c) Personnel of the U. S. Waterways Experiment Station. 
(e) Experlmental, for design of flood-control project.

(P) To determine the most effective plan for flood protection in the latitude of Morgan City, La.

(g) Study of Plood-control plans for the Lower M1881selpp1 R1ver and tributaries. The model 18 of the fired-bed type with scale ratios: horizontal dimenslons, 1:2000; vert1cal dimeneions, 1:100. Reproduced in the model are the main channel of the Miseiseippl River from Helena, Aris., (300 miles belon Cairo, I11.) to Donaldsonville, La., (900 miles below Calro, Ill.), the ent1re Atchafalaya Basin as far south as the Gulf of Mexioo; and the baokuater areas of the Arkansas, Wh1te, Yazoo, Ouachlta, and Red Rivers.

(h) All toote have been completed; preparation of elnal report is in progres.

(239) MODEL STUDY OF HIGH-LEVEL CROSSINGS, MORGANZA AND WEST ATCHAFALAYA FLOODWAYS, LOUISIANA.

(b) The President, M1solssippi River Commission, Vicksburg, M18s.

(o) Personnel of the U. S. Waterway Experiment 8tation.

(e) Experimental, for design.

(1) To determine flok conditions through and below proposed treatles, the possibility of 1mprovements in design, and the effects on otages upgtream from the embankments.

(g) Tests are proposed for high-level orossings at three locations: the rallroad and highway crossings of the West Atchafalaya Floodway at the Krotz 8prings, La. : the rallroad croseing between Mckneoly and Redcross, La.; and the rallroad and highway crossings at Morganza, La. The invest1gation w11l entall the measurement of velocitieg as well as stages for constant flows of var1ous magnitudes. The study w1Il require the construction and operation of two models of the flxed-bed type, which will be bullt succeselvely on tho same site to horizontal scales of 1:600 and vertical scales of 1:50. Tho model of the West Atchafalaya Floodway will include the leveed floodway between latitudes $30^{\circ} 4 I^{\prime} \mathrm{N}$ and $30^{\circ} 26^{\prime} \mathrm{N}$; that of the Morganza Ploodway w1Il include the leveod floodway from 1ts entrance (about latitude $30^{\circ} 50^{\prime} \mathrm{N}$ ) to latitude $30^{\circ} 35^{\circ} \mathrm{N}$.

(b) Design of the model is in progress.

(240) MODEL BTUDY FOR THE INVESTIOATION OF VALLEY BTORAGE CAPACITY, MI8SISBIPPI RIVER.

(b) The President, Miseiselppi River Commiselon, Vicksburg, M18s.

(o) Personnel of the U. S. Waterways Experiment station.

(e) Experimental, for general information.

(I) To develop storage increment curves of various reaches of the Lover Mise1solpp1 River.

(g) Thls is a study of the valley storage capacity of the Lower M18018a1pp1 River. The model is of the flxod-bed typo with cale rat1os: horlzontal dimenelons, 1:2000; vertical dimens10ns, 1:100. Reproduced in the model are the main channel of the Milesiesippi River Prom Helena, Ark., 1300 miles bolow Cairo, Ill.) to Donaldeonville, La., (900 miles below Calro, II.): the ent1re Atoharalaya Basin as far south as the Gulf of Mexioo; and the backwater areas of the Arkansas, White, Yazoo, Ouachita, and Red Rivers.

(h) Testing has been suspended for an indeplnite period.

(241) MODEL STUDY OF FLOOD CONTROL PLANS, YAZOO BACKWATER AND HEADWATLR ARTAB.

(b) The District Engineer, U. S. Englneer Off1ce, Vicksburg, Miss.

(c) Personnel of the U. S. Waterways Experiment station.

(e) Experimental, for design of llood-control project.

(1) To determine the effect of Yazoo Backwater and Headwater Plans.

(g) Study of the Plood-control plang for the Lower M1881881pp1 River. The model is of the fixed-bed type with seale rat1os: horlzontal dimensions, 1:2000; vertical dimensions, 1:100. Reproduced in the model are the main ohannel of the M1siselpp1 River from Helene, Ark., ( 300 miles below Cairo, II1.) 
to Donaldsonville, La., (900 miles below Calro, Ill.); tho entire Atcharalaya Basin as far south as the Gulf of Mexico; and the backwater areas of the Arkansas, White, Yazoo, Ouachlta, and Red R1vers.

(h) All tests have been completed; preparation of the flnal report is in progress.

(242) MODEL STUDY OF WAVE AND SURGE ACTION, ANAHEIM BAY, CALIFORNIA.

(b) The Chlel, Bureau of Yards and Docks, U. S. Navy Dopt., Washington, D. C.: The D1strict Englneer, U. B. Englneer 01110e, Los Angeles, Cal11.; and the Long Beach Harbor Dept., Clty of Long Beach, Calif.

(c) Personnel of the U. S. Waterways Experiment station.

(e) Experimental, for design.

(1) To determine the best loostion and allgnment for the proposed extension of the sen Pedro Bay detached breakwater system. Other aspeots of the investigation conoorned the determination of the relative elfocts of the alignment and location of the shore connecting elements of the breakwater eystem on the stability of sunset Beach, and the characteristios of the current patterns w1thin the breakwater enclosure relative to pollution in the enclosed harbor.

(g) Anabelm Bay in Orange County, Cal11., is located betweon Seal Beach and Sunget Beach about geven mlles downcoset from the Los Angeles River. The Anahe1m Bay entrance lieg downooset from the present terminus of the san Pedro Bay detached breakwater aystem. To provide protection from wave and aurge aotion for the Naval magazine and net Dopot Harbor in Anahoim Bay, tho Navy constructed converging jetties at the harbor entrance. The general plan involves the completion of the partially conetructed east-west detached breakwater to, or near, the shore line some distanoe below Anahelm Bay. In conjunction with this general plan, the removal of the Navy jettios is contemplated. The model is of the flxed-bed typo, exoept for sunset Beach which is reproduced on a movable bed, with linear scale ratios of 1:300 hor1zontal, and 1:60 vert1cal. The model reproduces all of the Ban Pedro Bay coast line southward from a polnt about 8000 feet cosetwise and northeast of the mouth of the San Gabriel River to Bolsa Bay, and the offehore hydrography of Ban Pedro Bay to about the $40 \mathrm{ft}$ depth contour. The reproduood shore-ine elements included Seal Beach, Anaheim Bay, and 1to harbor Pao1lities and sunset Beach. The model is equippod with ajjustable wave maohlnes for reproducing the prototype wave character1st1co. Have helghts are measured and recorded by electrical devices. Sunset Beach 18 molded to recent survey contours and erosion and accretion 1 d determined by soundings. Pollution oheracteristios are determined by plotting the paths of surface ploats.

(h) All tests have been completed; proparation of the final report is in progress.

(243) MODI STUDY OF BALT WATER INTRUBION, CALCABIEU RIVER, LOUISIANA.

(b) The Distriet Engineer, U. S. Engineer Office, New Orleans, La.

(c) Personnel of the U. 8. Waterways Experiment station.

(e) Experimental, for navigation improvements.

(1) To determine the effects of deepening the ship channel to 34 ft on the intrusion of salt water into the Calcasleu River and the passage of salt water eastward through the Intracoastal Waterway Prom the Calcasieu R1ver to the Mermentau River Basin.

(8) The project provides for deepening the present Calosileu River channel Irom Lake Charles, La., to the Gull of Mexioo from 30 ft to 34 ft. The model is of the Plxed-bed type with scale rat10s: horlzontal dimensions, 1:1000; vertical dimensions, $1: 50$. All of the Calcasiou River and Lake, Prom the head of tide above Lake Charles to Calcasleu Pass in the Gulf of Mexico, 18 reproduced in the model, and approximately 10 miles of the Calcasieu RiverSabine River seotion and 10 miles of the Calcasleu River-Mermentau River section of the Gulf Intracoastal Waterway. The model is equipped with automatic tide controlo in order to reproduce observed prototype tides in the Gulf of Mexico and in the east and west sections of the Intracoastal Hatemay. Balt water of the correct density is introduced into the ocoan water-supply syotem, and Iresh water in the correct volume is introduced at the upper end of the model.

(h) All tests have been completed; preparation of final report is in progress. 
(244) (1232) MODEL STUDY EOR ELIMINATION OF BHOALING, DEEPWATER POINT RANGE, DELAWARE RIVER, PENNGYLVANIA.

(b) The District Englneer, U. B. Englneor OPf10e, Philadelphla, Pa.

(o) Personnel of the U. S. Waterway Experiment station.

(e) Exper1mental, for nav1gation 1mprovement.

(i) To Investigate plans proposed for roducing shoaling in Deepwater Poin Range, Delaware River.

(g) The project provides for a channel about 96 miles lon and of varlous speo1lied dimensions extending Pror Philadelphia to deep water in Delavare Bay. Included in the project are the construction of dikes and training walls for regulation and control op tidal plow, and dredging to provide adequate anchorages at several points. Deepwater Polnt Range, a section of the main river channel, 1s looated botween Deepwater Point and Kilcohook disposal area. Th1s channel shoals at an average annual rate of nearly 2,800,000 ou yd. The model, orlg1nally used for a study of the Chesapeake and Delaware Canal and revised for the Wilmington Harbor 9 tudy, 1 of the fixed-bed, silt-injection type with scale rat1os: horizontal dirensions, 1:800; vertical dimensions, 1:80. T1des and ourrents are reproduced in the model by automatic tide gater.

(h) All tests have been completed; preparation of flnal report is in progress. (Refer also to Projeot No. 245, Model study for the elimination of shoaling in New Cartle and Flnns Point Ranges, Delaware R1ver, Pennsylvania".)

(245) (1232) MODEL STUDY FOR THE ELIMINATION OF SHOALING IN NEW CASTLE AND FINNS POINT RANGES, DELAWARE RIVER, PENNBYLVANIA.

(b) The District Englneer, U. S. Engineer Off1ce, PhIladelphia, Pa.

(o) Personnel of the U. S. Waterkay Exporiment station.

(e) Experimental, for channel 1mprovament.

(f) To test plans proposed for reducing shoaling in New Castle and Finns point Range 8, Delaware River.

(g) The project provides for a channel about 96 miles long and of varlous spac1fied dimensions extending from Philadelphia to deep water in Delaware Bay. Included in the project are the construction of dikes and training walls for regulation and control of tidal flow, and dredging to provide adequate anchorages at several points. New Castle and Plnns Point Ranges (sections of the maln river channel) are located between K1lcohook disposal area and the Chesapeake and Delaware Canal entrance. The ranges together ahoal at an average annual rate of $2,000,000 \mathrm{cu} \mathrm{yd}$. The Chesapeake and Delaware Model as revised for the Wlimington Harbor study is belng used for the tests. The rodel is of the fixed-bed, silt-injeotion type with scale rat1os: horlzontal dimensions, 1:800; vert1cal dimensions, 1:80. Tides and currents are reproduced in the model by automatic tide gatea.

(a) All tests have been completed; preparation of plnal report is in progress. (Refer also to Project No. 244, Model study for elimination of shoaling, Deepwater Polnt Range, Delaware Bay, Pennsylvan1a!..)

(246) MODEL STUDY OF LYNNHAVEN BAY, VIRGINIA.

(b) The D1strict Engineer, U.S. Engineer office, Norfoli, Va.

(o) Personnel of the U. S. Waterways Experiment station.

(e) experimental, for navigation improvements.

(1) To develop the most efficient design of inlet and interior channels to provide the desired volume of tidal flow into and out of Lynnhoven Bay.

(g) The project consiats of plans for the development and maintenance of inlet and interior channels through the shoals that now retard tidal flow through the inlet and into the waters of the bays tributary to the inlet, and for the developent of jettios to prevent reshoring of the inlet channels. The model w1ll be of the fixed-bed type, reproducling all of Lynnhaven Bay and Inlet and a portion of Chesapeake Bay adjacent to the inlet bufficiently large for accurate reproduction of observed prototype tides and ourrents. scale rat1os: horizontal dimensions, 1:800; vertical dimensions, 1:80. 
Prov1810ns w11l be made for reproducing prototype tides and tidal currents to scale throughout the model, and for vary1ng the widths and doptho of the Inlet and Interlor channels to determine the opt1mum channel oross-seotions required to provide the desired tial llow into and out of Lynnhaven Bay.

(h) Design of the model is in progress.

(247) MODEL STUDY OF ENTRANCE CHANNEL CURRENTS, MIDWAY ISLANDS.

(b) The Chlef, Bureau of Yarda and Docks, U. S. Navy Department, Washington, D.C.

(o) Personnel of the U. S. Waterways Experiment Station.

(e) Experimental, for design.

(1) To determine the best plan for reduction of the entrance channel currents. These entrance channel currents are caused by the rising of the lagoon waters above the aurrounding ocean area. Thls phenomenon 18 caused by wave action coupled with the pecullar physlcal features of the atoll.

(g) The small atoll, known a Miday Islands, 18 located about 1300 statute miles northwest of Honolulu, Terrltory of Hewa11. Th1s atoli has been developed as a naval operating base w1th harbor facllitles for submarlnes, tankers, and crulsers. An entrance channel on the south alde of the atoli leads from the Paciflc ocean into the submarire basin and lagoon mooring area. Wave action ra1ses the level of the lagoon sometimes as much as 2 leet above the surrounding ocean area which 18 accompanied by rery strong currents in the entrance channel. The ourrents coupled with the ection of wind and waves make navigation conditione very diflicult in the entrance channel, espec1ally at the channel mouth. The Improvement plans proposed varlous schemes such as widening the channel wouth, widening the ohannel Prom 400 to 1000 peet, in 200 seet increments, in comb1nation with varlous lengths of breakwaters on the west side of the ohannel, and enclosing the deep water area of the central lagoon by an 1mpervious breakwater. The model was of the plxed-bed type with linear scale rat1os of 1:500 hordzontal and 1:100 vert1cal. The model reproduced the ent1re atoll and the Pac1p10 ocean to about the 120 It depth contour. The model as equipped 1 th adjustable wave machines for reproducing to acale the prototype wave characterist1cs. A clrculating system attached to the model oupplied the proper amount of water to maintain a constant ocsan level at the channel mouth. The current magnitudes were measured with ploats and a minfature current meter. Wave helghts were measured and recorded by electricel devices.

(h) All teato have boon completed; preparation of the inal report is in progreas.

(248) MODEL STUDY OF LYNNHAVEN INLET, VIRGINIA.

(b) The District Englneer, U. S. Englneer offlce, Norpolk, Va.

(c) Personnel of the U. S. Waterways Exper1ment Station.

(e) Experimental, for navigation improvements.

(P) To determine the effectiveness of jetties in preventing reshorling of the inlet channel as developed from teats on the Lynnhaven Bay fixed-bed model, and to determine the epfects of jetties on the beaches adjacent to the inlet.

(g) The project conslats of plans for the development and maintenance of lnlet ard lnterlor channels through the shoals that now retard tidel plow through the inlet and into the waters of the bays tributary to the inlet, and for the development of jettles to prevent resboaling of the inlet channel. The model w1Il bo of the movablembed type, reproducling Lynnhaven Inlet and adjscent beaches for a distance of about 10,000 pt to the east and west of the $1 \mathrm{nl}$ t, and off-shore areas to about the minus $25 \mathrm{ft}$ contour of depth. in Chesapeake Bay. Scals rat1os w1ll be: horlzontal dimensions, 1:400; vertscal dimensions, 1:80. Provisions w11l be made for reproducing wave from any direotion between northeast and northwest and tides of any type. The littoral and tidal currents that flow slong the southern shore lire of Chesapeake Bay in the vicinity of Lynnhaven Inlet w1ll also be siaulated in the rodel.

(b) Modsl is under construction. 
(249) MODEI STUDY OF WAVE AND SURGE ACTION, MONTEREY HARBOR, CALIFORNIA.

(b) The District Engineer, U. S. Engineer Office, san Francieco, Callf.

(c) Personnel of the U. S. Waterways Experiment station.

(e) Experimental, for the design of harbor improvemente.

(P) To determine (a) the locations for a proposed companion breakwater and pruject-breakwater extension whioh will afford maximum protection for anchorage while not subjecting the harbor to pollutlon; (b) the best method of reducling the effects of surge action and deposition adjacent to Municlpal Whare No. 1 ; and (c) the effects of installing an axphiblous training base.

(g) Proposed 1mprovements for Monterey Harbor, Cal11., comprise (a) lengthening of the existing breakwater by $2000 \mathrm{ft}$, and construction of a 1500-pt long compenion breakwater extending from shore in such a way as to form an enclosed harbor with a navigation entrance; (b) dredging adjacent to Munic1pal Whare No. 1 ; and (c) Installation of an amphiblous tralning base for 81xth Army. The model 18 of the plyed-bed type, w1th a linear scale rat10 of 1:100, model to prototype. Its limits include all of Monterey Harbor and a sufficlent area of Konterey Bay to the northwest, north, and east to permit reproduction of wave action from critical directions. Wave action 1o simulated by specially dealgned wave machines preolsely callbreted to attain the requisite time and elevation ranges sor the study. Amplitude and Irequence results are measured throughout the problem area by osc1110graphs whlch record the 1mpulses resulting from wave action on electrical wave-measuring rods aystemat1cally located at speo1flc stations. The morol cover 6000 eq $\mathrm{ft}$ represent1ng a prototype area of 2.34 square miles.

(b) Testing 18 in progress.

(250) MODER 8TUDY OF SALINITY INTRUSION, NEW YORK BAY-DELAWARE RIVER SECTION OF THE INTRACOASTAL WATERWAY.

(b) The Dietriot Englneer, U. B. Englneer Opflce, New York, N. Y.

(c) Personnel of the U. S. Watemays Experiment station.

(e) Experimental for general information.

(1) To determine the quant1ty of preah water required for operation of the Sayreville locks, Including flushing and soaveng1ng water; and to develop the most effective location and design of the salt-water sump and dralns.

(g) The proposed Nen Jersey shlp Canal would extend a distance of about 34 m1les across the state of New Jersey Irom Bayrev1lle, N. Y., on Rarltan Bay (the most westerly arm of New York Bay) to the Delaware River at Borcontown, N. J. In order to prevent intrusion of salt water Prom Rasitan Bay in the upper reaches of the canal and the Delaware River, it is proposed to malntain an upper-pool elevation of 10 ft above mean low water (at Bayreville) by means of locks and dams at both ends of the canal, the sayroville end to be so deslgned ss to be kept salt-pree by plushing and scavenglng. The canal would be navigable by veseels of 25 pt draft w1th the upper pool drawn down to 5 ft above mean low water. Two modols wore involved in this atudy: (a) a 1:50-scale model reproducing the locks with a amel portion of the lower and upper pools and with the salt-water swep and dralns. The shlp and Barge locks were bu1lt w1th all appurtenanoes for P11ling and llushlng: (b) a 1:150-scale comprehens1ve model of the flxod-bed type reproducing all of the upper pool and 11 miles of the canal in which ocavonging of galt water from the art1plolal lake (upper pool), well a norosohment of oalt water into the canal, was ctuled.

(b) All tosts have been oomleted.

(251) (1233) MODEL STUDY OF BAVAWAP RIVER HARBOR, GEORAIA.

(b) The Diatriot Englneor, U. B. Englneor ofPloo, Savannah, Ga.

(o) Poreonnel of the 0 . 8. Watemays Experiment station.

(o) Experimental, for harbor 1mprovements.

(1) To atudy means of lmproving and melntalning the ship ohannel sroil savannah, Ca. to deop water in the Atlant10 Ocoan, consideration being given to the efpect of proposed improvement on adjacent reoreation beaohes.

(g) The projeot for the 1mprovement of Bavannah Harbor Includes the rev1sion of 
existing jetties at the mouth of the Savannah River, the relocation of the 1nland waterway through the harbor, and the enlargement of the ship channel at various points. The model was of the flxed-bed type with scale ratios: horlzontal dimensions, 1:1000; vertical dimensions, 1:150. Reproduced in the model were the Savannah River from the head of tidewater to the mouth, and all areas in the vicinity of the mouth which are subject to tidal flow. Two automatio tide controls were used for tidal reproduction. Salt water of the correct specif10 gravity was introduced through the ocean supply valve, and was colored with potassium permanganate to permit visual observation of salinity currents.

(b) All tests have been completed; preparation of f1nal report 18 in progress.

(252) PILOT MODEL STUDY OF SOUTHWEST PASS, MISSISSIPPI RIVER, LOUISIANA.

(b) The Division Engineer, Lower Mississippi Valley Division, V1cksburg, Miss.

(c) Personnel of the U. S. Waterways Experiment station.

(e) Experimental, for model design.

(e) (a) To develop special model appurtenances and operating technique required to reproduce prototype density currents in Southwest Pass by the simultaneous removal of salt water and introduction of fresh water at the upstream end of the model; and (b) to select a movable-bed material that will move at the same rate (to scale) as that of the prototype w1thout serlous exaggeration of the model discharge and velocity scales. These data and model appurtenances $\mathbf{1 1 1}$ be used for a later comprehensive model study of Southwest Pass.

(g) The project for southwest Pass provides for development of plans for elimination or reduction of shoaling in the Southwest Pass Bar Channel. The model w1ll be of the movable-bed type, and w1ll include Southwest Pass from mile 5 below the Head of Passes to the ends of the jetties, and a 2.25 sq $\mathbb{m} 1$ area of the Gulf of Mexico adjacent to the jettles. Scale rat1os will be: horlzontal dimensions, 1:500; vertical dimensions, 1:100. Prov1s1ons w1ll bo made for reproducing prototyoe tides and tidal currents in the simulated Gulf of Mexico, density flow and fresh-water river flow in Southwest Pass, and the movement of bed-load material in lower southwest Pass and the bar channel. The model w1ll be so designed and constructed that 1 t can be enlarged for the later compreheneive study of Southwest pass at minimum oost and time.

(h) Design of the model is in progress.

(253) MODEL STUDY FOR CHANNEL INPROVEHENT, ST. JOHNS RIVER, FLORIDA.

(b) The District Eng1neer, U. S. Englneer office, Jacksonv1lle, Fla.

(c) Personnel of the U. S. Waterways Experiment Station.

(e) Experimental, for navigation 1mprovements.

(f) To determine the best location and alignment of the cut-off and the effect on navigation of the cut-off and the deepening of the present channel to 34 ft.

(g) The project provides for a cut-off in the st. Johns Riverobelow Jacksonville, Fla., which w1ll extend from Dames Point to Fulton in connection with deepening of the present channel from Jacksonville to the Atlantic Ocean to a depth of $34 \mathrm{ft}$. The model $1 \mathrm{~s}$ of the flxed-bed type with scale ratios: horlzontal dimensions, 1:1000; vertical dimens1ons, 1:100. The model 1ncludes the st. Johns River from Welaka, Fla., to the Atlantic ocean, as well as approximately $81 \times$ m1les of the Intracoastel Waterway to the north and south of the st. Johns River. The model is equipped with automatic tide controls in order to reproduce the observed prototype tides in the st. Johns River and in the north and south sections of the Intracosstal Waterway. Salt water of the correct density is introduced into the ocean water-supply system, and fresh water 18 introduced at the upper end of the model.

(h) All tests have been completed; preparation of pinal report is in progress.

(254) MODEL STUDY OF POLLUTION, ST. JOHNS RIVER, FLORIDA.

(b) The City of Jacksonville, Florida.

(c) Personnel of the U.S. Waterways Experiment station.

(e) Experimental, for information. 
(f) To devise a system of training walls which would prevent pollution by raw sewage along the west bank of the St. Johns River between the mouth of Ortega River and Winter Point.

(g) The study was conducted on the St. Johns Rlver model previously used for a study of navigation improvement of St. Johns R1ver. (See Project No. 253, "Model study of channel improvement, St. Johns River".) The model is of the elxed-bed type with scole ratios: horizontal dimonsions, 1:1000; vertical dimensions, 1:100. The model includes the St. Johns River from Welaka, Fla., to the Atlant1c Ocean, as well as approximately $81 x$ miles of the Intracoastal Waterway to the north and south of the St. Johns River. The model is equipped with automatic tide controls in order to reproduce the observed prototype tides in the St. Johns River and in the north and south sections of the Intracoastal Waterway. Salt water of the correct density is introduced into the ocean water supply system, and fresh water is introduced at the upper end of the model.

(h) All tests have been completed; preparation of a final report 1 s in progress.

(255) MODEL STUDY OF SHOALING IN THE BAR CHANNEL, UMPQUA RIVER, OREGON.

(b) The Dlstrict Engineer, U. S. Engineer Office, Portland, Ore.

(c) Personnel of the U.S. Waterways Experiment Station.

(e) Experimental, for navigation improvements.

(I) To determine whether or not the relocation or improvement of the South Jetty w111 efiect an appreciable decrease in the present heavy rate of shoaling in the entrance channel.

(g) The project for the improvement of Umpque River consists of plans for the relocation or improvement of the South Jetty and maintenence of an entrance channel 26 ft deep and of suitable width. The model is of the morable-bed type, the movable-bed reach extending 10,000 it north of and 10,000 ft south of the mouth of the Umpqua RIver and offshore to about the 80-ft contour of depth in the ocean. The river is reproduced from the mouth to a point above winchester Bay. Scale ratios: horizontal dimensions, 1:400; vertical dimenalon, 1:80. Provislons are made for reproduclng waves from any direction from northwest to southwest, t1des of any type, and littorsl currents either up or down the coast.

(h) Testing is in progress.

(256) (969) MODEL STUDY OF WAVE FORCE AGAINST BREAKWATERS.

(b) The Division Engineer, Great Lakes Division, Chicago, Ill.

(c) Personnel of the U. S. Waterways Experiment station.

(e) Experimental, for desizo of harbor lmprovements.

(f) To develop vertical pressure curves (showing the pressures resulting from waves striking agalnst breakwaters) to be used as a basis for the design of breakwaters. Four variables will be investigated and the resulting vertical pressure cur s developed. These varlables are (a) helghts and lengths of waves; (b) depth of water and slope of bottom; (c) shape of breakwaters; and (d) angle of impingement of waves.

(g) In designing breakwaters it is often necessary to know the magnitude of the wave force exerted thereon. This has been computed theoretically or measured at single points by dynamometers, but neither method is considered satisfactory. This project provides for the determination by model tests of the form of the vertical pressure curve, and of the relation betwoen pressure ordinates and wove helghts. The investigation is conducted in a 5-Pt by 18-it by 117-pt concrete tank equipped with a 4 - it by 8 - 1 t viewing window In the tank 8 side at the brealswater. A plunger-type wave machine capable of producing a l-it wave is used. Wave pressure 18 measured by a bank of specially developed pressure cells and recorded, simultaneously with wave helghts, on a geven-element osclllograph. Wave heights are determined by means of an electric wave-height measuring device developed at the Experiment Station.

(h) Study suspended for indefinite period. 
(257) MODEL STUDY OF STABILITY OF RUBBLE-MOUND BREAKWATERS.

(b) The Chief, Bureau of Yards and Docks, U. S. Navy Dept., Washington, D. C.

(o) Personnel of the U. S. Waterways Experiment station.

(e) Experimental, for design.

(1) The primary purpose of the model study is to determine the most efplclent design of a composite rubble-mound breakwater, and to determine the effect of the dynamic forces of wave action on the breakwater during different phrses of construction.

(g) The rubble-mound breakwater stability study 18 being conducted in a 5-1t by 18-1t by 117-1t concrete tank equipped with a plunger-type wave machine. The wave helghts and lengths are measured by electrical measuring devices. A hypothet1cal prototype breakwater is reproduced in the model using scale rat1os of $1: 30,1: 45$, and $1: 50$. The rubble-mound brealswater structure conslsts of three types of materlals: class-C ilne core materlal, class-B enrockment for the class-C materlal, and class-A rock used to form the cap of the breakwater. Each class of materlal makes up a section of the breakwater structure which 18 subjected to storm waves of $15 \mathrm{ft}$ by $270 \mathrm{ft}$ and $21 \mathrm{ft}$ by $300 \mathrm{ft}$ unt1l stab1lization of the breakwater section $1 \mathrm{~s}$ reached. The model breakwater reproduces to scale (I1near, welght, and volume) the prototype breakwater des1gns and speclf1cations.

(b) Testing 18 in progress.

(258) MODEL STUDY OF WAVE AND SURGE ACTION, NAVAL OPERATING BASE, TERMINAL ISLAND, SAN PEDRO, CALIFORNIA.

(b) The Chief, Bureau of Yards and Docks, U. S. Navy Dept., Washington, D. C.

(c) Personnel of the U. S. Waterways Experiment Station.

(e) Experimental, for design.

(1) To determine the best plan for protecting the Navy piers and arydocks at the Naval Operat1ng Base, Terminal Island, San Pedro, Calit, from the effecta of wave and surge action.

(g) The above-mentioned Navy plers and drydocks are located along an east-west marelnal wall on the southern shore line of Terminal Island. Terminal Island 1s located about half way between the cltles of San Pedro and Long Beach, Cal1f. Terminal Island and most of San Pedro Bay 1s protected, to a certain extent, by an outer breakwater system about 6.5 miles in length. However, at times this outer breakwater system allows a sufflclent amount of wave energy to reach the pler area to cause troublesome conditions for moored ships. The 1mprovement plan conslsted of the construction of a mole which would surround the Navy plers and drydocks. Thls plan was devised to provide protection to the existing factlities and to provide an enlarged operating base. The model was of the pixed-bed type with linear scale rat1os of 1:300 horizontal, and 1:60 vertical. The model reproduced all of the coast line from Pt. Femin to Anahe1m Bay, Cal19., the Los Angeles river and outer harbors, Long Beach river and outer harbors, all of Ban Pedro Bay, the San Pedro breakwater, the detached breakwater and a large area of the Paclilc Ocean south of the detached breakwater. The model was equipped w1th adjustable wave machlnes for reproducling to scale the prototype wave oharacter1st1cs. Wave heights are measured and recorded by electrical dovices.

(h) All tests have been completed; preparation of the final report is in progress.

(259) MODEU STUDY OF BREAKWATER LOCATION, U. S. NAVAL AIR STATION, ALAMEDA, CALIFORNIA.

(b) The Chtef, Bureau of Yards and Docks, U. S. Navy Dept., Washington, D. C.

(c) Personnel of the U. S. Waterways Experiment Station.

(e) Experimental, for design.

(1) To determine the best plan for reducing wave action at the carrier pler and in the seaplane lagoon, and for reducing shoaling in the dredged turning basin at the U. S. Naval Air Station, Alameda, Calif.

(g) The U. S. Naval Alr Station, Alameda, Cal11., has Pacllities for both land and sea-type alrcrait and naval shlps of vorlous types. These installatlons are located west of Alameda, Cal1f., along a section of exposed shore line 
of San Pranc1sco Bay. The location of the Naval Air 8tation 18 such that the docking fac1litios are exposed to local storm waves and the dredged turning basin 18 shosled considerably by the deposition of silt transported In suspension by the ebb-tide currents erom mud plats southeast of the turnIng basin. The proposed plans of improvement conslsted of several breakwater plans so located as to follow the general allgnment of the south line of the turning basin and entrance ohannel. The model was of the fixed-bed type with linear scale rat1os of 1:200, horlzontal and vert1oal. The model reproduced the shore line adjacent to the prototype, the seaplane lagoon, the carrier pler, the entrance channel and turning basin, and a part of the adjolning area of San Franc1s00 Bay. The model was equipped w1th adjustable wave machines for reproducing the prototype wave characterlst1es. A olroulat1ng system attached to the model reproduced prototype ebb-t1de currents. G1leonite was used for silt materlal and this materlal was introduced into the model through a system whioh consisted of a mixing tank, pipe I1nes, and perforated troughs. Ware helghts were measured and recorded by eleotrical devices. The depths of model silt deposits were measured by soundIng and the volumes of silt determined by graphlcal methods.

(h) All tests have been completed; preparation of the inal report is in progress.

U. S. DEPT. OF AGRICULTURE, FOREST SERVICE, Gallfornla Forest and Range Experiment Station, Bericeley, Calif.

Inquirles concerning Project Nos. 261 to 265, 1nol, should be addressed to Mr. 8. N. Wyokof1, D1rector, or Mr. C. J. Kraebel, in charge D18181on of Forest Influences, California Forest and Range Experlment station, Berkeley, Cal1f.

\section{(260) (1303) EFFECT OF BEDLOAD AND CHANNEL SLOPE ON RATING OF SAN DIMAS} METERING FLUME.

(b) Cal1fornia Forest and Range Experiment Stat1on, Forest Service, U. S. Dept. of Agriculture, and other agencles, measuring loaded strear flow and flow In steep channels.

(d) S. N. Wyokoff, Director, California Forest and Range Experiment station, Berkeley, Cal1f.; or Prof. M. P. O'Brien, University of Cal1fornia, Berkeley 4, Calle.

(e) Laboratory project in cooperation with the University of California.

(f) Calibration of the San Dimas metering flume under various conditions of bedload and ohannel slopes.

(g) Laboratory experimente on models.

(b) Equipment 1nstalled, but project now 1nactive.

(261) (1305) WATERSHED MANAGEMENT (Southern Cal1pornia).

(b) Cal1fornla Forest and Range Experiment stat1on, Forest Service, U. S. Dept. of Agrioulture, and other ageno1es responsible for the management of watersheds and production of water supplies.

(c) J. D. Slnola1r, P. B. Rowe, H. C. Storey, E. L. Hamilton, J. S. Horton, E. A. Colman.

(e) Comprehensive investigation of hydrology, erosion, and related studies in mountalnous vatersheds of California, inoluding laboratory studies at seleoted fleld stations and at Berkeley headquarters.

(1) (1) To study the disposition of ralnfall as influenced by watershed condit1ons including topography, geology, so11s, and vegetation; and (2) to develop methods of watershed management which v1ll assure both the maximum yleld of usable water and satisfactory regulation of flood runoff and erosion.

(g) Major work center is the San D1mas Experimental Forest, a 17,000-aore area on the south slopes of the San Gabrlel mountalns comprising Big Dalton and San DImas Canyons. More than 400 raln-gages have been 1nstalled to measure rainfall. Ten large and seven small watersheds within the two drainages are equipped with gaging stations to measure streamflow. The seven small watersheds also have reservolrs to measure erosion. The Big Dalton and San D1mas 
reservo1rs of the Los Angeles County Flood Control District provide measurements of runoff and erosion from the two main drainages. More 1ntensive measurements of surface runoff and erosion are obtalned from elghteen small plots. A ser1es of twenty-81x large lje1meters 18 designed to compare the use of water by the more important speoles of shrubs and one specles of pine. Essential climat1c data have been obtalned from several meteorological stations w1thin the Experimental Forest.

(b) Collection of records was begun upon completion of each research installation, principally during the period 1933 to 1937 , and continued on the ont1re Exper1mental Forest unt1l October 1, 1946. The loss of emergenoy assistance last year made 1 t necessary to suspend about elghty percent of the hydrologio records. Aotivities now in progress include:

(1) The continuation of precipitation and streamflow measurements from two large watersheds, and erosion records from seven small watersheds. The serles of large lysimeters and essentlal climatic measurements are also being malntalned. (2) Special rainfall studies including rain-gage placement in relation to topography, the use of shields, the study of storm components and comparative intensity measurements within the watershods referred to above. (3) The development of a direct reading electrical so11 mo1sture meter. (4) The analys1s of accumulated data and preparation of reports for publication.

(1) "Water for the year 2000." stuart 0. Blythe. Cal1fornia Magazine of Pac1f1c Bus1ness, Vol. 26, No. 11: 20-23, 51-52. November 1936.

"Flghting flre and llood with solence." Union 011 Bulletin, Vol. 19, No. 8: 14-19. August 1938.

"Measurement of debris-laden streamflow. w1th crit1oal-depth flumes." H. G. W1Im, John S. Cotton, and H. C. Storey. Trans. A.S.C.E., Vol. 103, No. 9: 1237-1278. September 1938.

"The forest floor of the ohaparral in San Gabrlel Mounta1ns, California." Joseph K1ttredge, Jr. Jour. Agr1. Re8., Vol. 58, No. 7: 521-535. Apr11 1939.

"The annual accumulation and creep of litter and other surface materials in the chaparral of the San Gabrlel Mounta1ns, Cal1forn1a." Joseph K1ttredge, Jr. Jour. Agr1. Res., Vol. 58, No. 7: 537-541. Apr11 1939.

"An analysis of preolpitation measurements on mountain vatersheds." H. G. W1lm, A. Z. Nelson, and H. C. Storey. Monthly Weather Review, Vol. 67: 163-172. June 1939.

"The San D1mas Experimental Forest." C. J. Kraebel and J. D. Sincla1r. Trans. American Geophysical Union, Pt. I: 84-92. 1940.

"The San D1mas Experimental Forest." E. L. Ham11ton. Boc1al studies Rev1ew, Vol. 16, No. 5: 10, 12-14. October 1940.

"Topographic influences on preclpltat1on." H. C. Storey. Proo. S1xth Pac1f1c Sclence Congress at Berkeley, Cal11., 1939. So11 Resouroes, Vol.4: 985-993. JuIy 1941.

The sample plot as a method of quant1tat1ve analys18 of chaparral vegetat1on in Southern Californ1a." Jerome 8. Horton. Ecology, Vol. 22, No. 4: 457-468. October 1941 .

"A comparative study of rain gages." H. C. Stores and E. L. Hamilton. Trans. American Goophysical Union, Pt. I: 133-141. 1943.

"A system for the synchronization of hydrologic reoords." E. L. Ham1lton. Trans. American Geophysical Union, Pt. II: 624-631. 1943.

"A Nomograph for the integration of atream flow records." Paul B. Johnson. C1v11 Englnoer1ng, Vol. 13, No. 10: 494-495. October 1943.

"Rainfall measurement as influenced by storm characterlat1os in southern Cal1fornia mounta1ns. E. L. Ham1lton. Trans. American Geophysical Union, Pt. III: 502-518. 1944.

"A comparison of vertical and t1lted rain gages in est1mating precipltation on mountain watersheds." H. C. Storey and H. G. W1lm. Trans. Amerloan teophys1cal Union, Pt. IV: 518-523. 1944.

"The San D1mas waterstage transmitter." E. A. Colman and E. L. Hamilton. C1711 Eng1neer1ng, Vol. 14, No. 6: 257-258. June 1944. 
"The wood rat 2.8 an ecological pactor in Southern Calliornia waterahed." Jerome S. Horton and John T. Wright. Ecology, Vol. 25, No. 3: 341-351. July 1944.

"The dependence of field oapacity upon the depth of wetting of fleld aolls." E. A. Colman. Bo1l solence, Vol. 5g, No. 1: 43-50. July 1944.

"Veloolty-hera rod calibrated for measuring stream Plow." H. G. Wilm and H. C. Storey. C18. Engo, Vol. 14, No. 11: 475-476. November 1944.

"Some quantitat1ve relations of poliage in the chaparral." Joseph K1ttredge, Jr. Ecology, Vol. 26, No. 1: 70-73. January 1945.

"Some 1mprovements in tenslometer deglgm. E. A. Colmen, W. B. Hanawalt, and C. R. Burck. Jour. Amer. Soc. Agron., Voi. 38, No. 5: 455-458. May 1946. "A laboratory study of lyg1meter aralnage under controlied go11 molstur: tension." E. A. Colman. Boll soleneo, Vol. 62, No. 5. November 1946. "The place of electrioal soll molature meters in hydrologie research" E. A. Colman. Trans. Amer1can Geophys1cal Union, Vol. 27, No. VI: 8479853. December 1946.

"Hydrologlc a spects of burning brush and woodland-grass sanges in Callgornta" Frank Adam, Paul A. Ewing, and Martin 凡。 Huberty. Calliorne gtate Bodre of Forestry, 41-46. January 1947.

whe San Dimas Rain Gage Mechanism." E. L. HandItors. (In print.) BuI. Amer. Met. Boc. 1947.

Report of the Commitae on Franspiration and Evaporation, Trans. Ameriogs Goophys10al Union: Part II: 401-402. 1943.

Part V: 683-684. Apr12 1945.

Vol. 26, No. III: 451-452. December 1945.

Vol. 27, No. $V: 720-721$. October 1946.

\section{(262) (1306) WATERSHED MANAGEMENT (Blerra NeVQda).}

(b) Californ1e Forest and Range Exporiment Stetion, Forest sorvice, U. S. Dept. of Agriculture, and other agencles responbible por the management of watersheds and production of water gupplies.

(o) Comprekenslve invest1gation ol hydrology, erosion, and related studis in mountalnous watersheds of California, including laboratory studio or

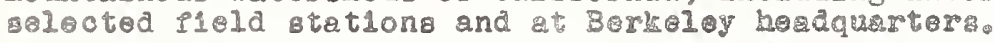

(s) Insertigation of the influence or preclpitation, physiography, vegetat1vo cover and watershed denudation or other treatment upon total water ylela snd rates of runotf and erosion.

(g) Hydrologic measurements in watersheds of varloug $120 \mathrm{~g}$ from 0.01 to 0.86 square miles, under normally vegetated cond1tions, denuded by \&lye, troated by grazing, logglng, or otherwise; and gtualas of meteorological factors, vegetat1on, so118, and geology of tho watershe arees. Major work center 18 Elngs River Branch Station within the Kings RIves dranage of tho vouthorn Slerre Nevada. Studieg have boen carr1od on at two type locel1t1eg. namely, Blg Creek and Teakettle Creek. The Blg Creek ares ranges In elevation Prom 1000 to 2500 feet and comprises seyen mal wsteraheds, 20 to 36

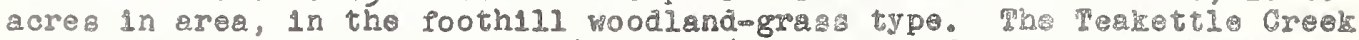
area renges in elevetion Prom 6000 to 8000 peet and compr1ses three 500 . acro wateraheds in the condier forest type with preclpitation iargely 1 n the form of snow. Research installationo include 4 clinatic etation, 100 rasn gager, 15 mow courses, and 12 strean gaging and oroston measuring atatนone.

(h) Collection of records was begun upon completion of each ogereh installaw tion, starting in 1936, and offloe reports prepered sumariasrgesens? masurements. It bocame necessary, due to the lack of aselstance, to susw pend the colloction of data from the Teakettle Creok area in 1942 and the B1g Croek area in 1946.

(1) "IInge Rlper Branoh Waterehed study un1ts。" B. M. Muraon. Californla Forest and Range Expersment Station Technioal Note No. 11. 1938.

(263) (I307) INILUENCE OF FOREST VEGETATION ON STREASFLOW AND SOIL EROSTON.

(b) California Forest and Range Experiment Statlon, Forest Bortide. U. D. Dept. of Agriculture. 
(c) P. B. Rowe and assistants.

(e) Extensive laboratory and fleld experiments of the influences of forest vegetation on the disposition of precipitation as they affect water yield, surfaca run-off, and erosion.

(r) Investlgations of the role of the coast chaparral and other vegetation, including mustard cover and varlous types of forest 11 tter, in the management of watersheds for flood and erosion control and the production of usable water.

(g) Three serles of lysimeters and three palrs of runoff and erosion plots supplemented by climatological installations were used to determine epfects of l1tter and vegetation, soll type, and slope on surface runoff, inf1ltration, evaporation, and erosion.

(h) Project discontinued. Analysis of data pending.

(264) (1308) INFLUENCE OF FOREST VEGETATION ON STREAMFLOW AND SOIL EROSION.

(b) Callfornla Forest and Range Experiment Station, Forest Serv1ce, U. S. Dept. of Agriculture.

(c) P. B. Rowe, H. W. Anderson, E. A. Colman, and assistants.

(e) Intensive fleld experiments of Influences of forest vegetation on the disposition of preclpltation as they alfect water yleld, surface runopi, and erosion.

(1) Invest1gations of the role of forest, woodland, and chaparral cover in the management of watersheds for flood and erosion control and the production of usable water.

(g) Experimental 1nstallations include: (1) At North Fork, Cal1fornia - S1erra Nevada footh11l woodland chaparral type: 3 palrs of 1/40-acre surface runoff and erosion plots established 1929; 2 palrs of 1/100-aore surface runoff and erosion plots eetablishod 1933 and equipped for obtalning data from natural and artiflcially applied rainfall; three 1/20-acre soll molsture sampling plots; 8 lysimeters; 2 streamflow-1nterception units; 3 soll temperature p1ts; 6 snow stations; 1 weather station, and varlous meteorological equipment; automat10 preclpitation and runofl recording devices. (2) At Bass Lake, Cal1fornia - Slerra Nevada second-growth ponderosa pine type: 2 triplicate sets of 1/40-acre surpace runof and erosion plots established in 1934; three 1/20-acre soll molsture sampling areas; I streamllow-1nterception unit; 5 snow courses; 1 standard weather station, and varlous meteorological equipment; automat1c prec1pltation and runof recording dev1ces.

(h) Collection of records suepended in May 1946. Tabulation and analyg1s of data in progress.

(1) "Some factors of the hydrology of the sierra Nevada foothills." P. B. Rowe. Trans. American Geophysical Union, Pt. I: 90-100. 1941.

Discussion of paper by Velhmeyer and Johneton ent1tled, "5011 molsture recorde from burned end unburned plots in certain grazlng areas of Cal1fornia". P. B. Rowe. Trans. American Geophysical Union, Pt. I: 84-86. 1944.

"The effect of freezing on 8011 moleture and on evaporation from a bars so11." Henry W. Anderson. Trans. Amerlcan Geophys1cal Union, Vol. 27, No. 6: 863870 . 1946.

"Soll Ireezing and thawing as related to some vegetation, climat1c and soll. varlables." Henry W. Anderson. Journal of Forestry, Vol. 45, No. 2: 94-101. 1947.

"Hydrolog1c aspects of burning brush and woodland-grass ranges in Callforn1a." Frank Adam8, Paul A. Ew1ng, and Martin R. Huberty. State of Callfornia D171sion of Forestry: 49-55. 1947.

"8ome Influences of woodland-chaparral vegetation on so1l-water relations." P. B. Rowe. Manuseript.

(265) (1309) INFLUENCE OF FOREST VEGETATION AND LAND USE ON STREAMFLOW AND SOIL EROSION.

(b) California Forest and Range Experiment stat1on, Forest Service, U. S. Dept. of Agriculture.

(c) P. B. Rowe and 2.8818tants. 
(e) Intensive fleld studies of the influences of varlous physlographlc, ollmatio, and blotio faotors as they affect the infiltration capaolty of solls.

(P) (1) To teat and perfect infiltrometer equipment for fleld ampling; (2) to determine the 1nfluenoe of such factors as soll type, vegetation cover, land use, and intensity and duration of rainfall on the infiltration cap. ac1ty of so1la; and (3) to develop methods of applying infiltration data in watershed hydrolog 10 analyses.

(g) The North Fork portable small plot inflitrometer, employlng both the North Fork and F. A. types of rainfall applicators and simllar equipment, teated and used in pleld inf1ltration studies. Studies of the relations between the environmental factors, Including land use, and the infiltration oapaoltes of solls as they affect runopf, water yleld, and erosion have been conducted on several watershed in California. Bome of the 11eld work was dors by the U. S. Dept. of Agrioulture, Flood Control Surveys.

(h) Projeot inactive at preaent.

(1) An Inflitration study of a denuded and a forest covered so11." P. B. Rowe, D. M. Ilch, and Rene Bollaert. Cal1pornla Forest and Range Experiment 8tation Research Note No. 14, mimeograph. 1937.

"The conatruction, operation, and use of the North Fork infiltrometer." P. B. Rowe. U. B. Dept. of Agriculture, Flood Control Coordinating Comm. Misc. Pub. No. 1. 1940.

"A method of hydrolog1c analys18 in watershed management." P. B. Rowe. Trana. American Geophysical Union, Pt. II: 632-649. 1943.

"D1scussion of 'Role of the land during flood perlods', by W. W. Horner." P. B. Rowe, Proc. A.8.C.E., Vol. 69, No. 10: 1616-1618. December 1943.

ECOLE POLYTECHNIQUE DE MONTREAL, Hydraul1c8 Laboratory, 1430 Rue sa1nt-Den1s, Montreal 18, Canada.

Inquirles conoerning Project No. 266 to 268 , 1nol., should be addressed to Prof. Raymond Boucher, Ecole Polytechn1que, 1430 Salnt-Den1a streot, Montreal 1.8. Canada.

(266) (639) HYDRAULIC MODEL STUDTES OF DIFFERENT SPILLWAY PROFILES.

(b) Laboratory project.

(c) Prof. R. Boucher and asalatants.

(e) General experimental research.

(f) To establish a comparison between the discharge capacities of different splliway designs.

(g) Studies are rade on concrete models of exlating and recommended splllway proflles. Ireasure diatribution on ap1liway faces and coefficlents of discharge are determined for varlous heads up to the design head. The effect of gate plers of varlous dosigns is also inveatlgated.

(b) seven different profiles have been studied, including two modifloationa of Creager-Justin profile upstream of crest line. The experimental work has been proceoding very 1rregularly in the last two years and w1ll be resumed during 1947.

(267) MODEL TESTS OF A LOG FLUME CONTROL BECTION.

(b) The Shawinigan Eng1neering Company, Ltd., Montreal.

(c) Prof. R. Boucher and assistants.

(e) Experimental project for de日ign information.

(f) To determine the efflciency of a control section for open channela conalst1ng of a laterally tapering section of channel with bottom aloping in the direction of flow.

(8) The model to a soale of $1: 7.5$ was 1nstalled in the 30-1nch glass-sided flume, preceded by a ahort length of rectangular channel. Tests were made for heads up to the designed head to determine discharge coefficients. Propiles of the nappe were also obtalned to complete observation of flow conditions. 
(h) Tests partly completed and test results submitted to the Shaw1nigan Englnoering Company.

(268) CALIBRATION TESTS OF A SHARP-CRESTLD PARABOLIC WEIR.

(b) Laboratory project.

(c) Prof. R. Boucher and assistants.

(e) Experimental project for general information.

(1) To obtain the head - discharge curves and head - discharge coefflclent curves for a sharp-crested parabol10 we1r (2l 1nches maximum w1dth by 18 inches maximum height) having a capac1ty of 3 cfs. Th1s we1r vill measure flows to a new 18-1nch by 30-1nch glass-8lded steel flume to be used for model testing and open channel studies.

(g) The brass weir plate was attached to the face of 1 ts stilling basin and the tests conducted on the whole set-up as to be used with the flume. Heads were determined in a stlling pot with a point gauge and discharges were measured by volume for larger flows and by welght for small flows.

(h) Tests completed. Computations partly completed. Report expected early next year.

UNIVERSITY OF TORONTO, Hydraul1c Laboratory, Toronto 5, Canada.

Inquirles concerning Project No. 269 and 270 should be addressed to Prof. G. Ross Lord, Dept. Of Mechanical Englneering, University of Toronto, Toronto 5, Canada.

(269) FLOW OVER SREW SPILLWAYS.

(b) Laboratory project.

(c) G. R. Lord, D. G. Huber.

(e) Experimental research.

(1) To obtaln discharge coefflelents for sp1llways whose crests are at other than $90^{\circ}$ to the axis of the approaching flow.

(g) It $1 \mathrm{~s}$ hoped that the coefflelents obtained will permit more accurate design of skew sp1llways.

(b) Most of the experimental work has been completed.

(270) ROCK FILL WEIHS.

(b) Laboratory project. (c) G. R. Lord. (e) Experimental research.

(f) To invest1gate the shape and discharge coeflicients of weirs formed by dropping rock into llowing water.

(g) The serles of testr is planned to yleld data which may bo used to design rock flll welrs such as those already constructed at DeCew Falls Power Plant of the Hydro Electr10 Power Commission of Ontarlo.

(h) The experimental work is half completed.

\section{COMPLETED PROJECTS}

(Project numbers, where g1ven, refer to Volume $\mathrm{x}, 1942$.

CALIFORNIA INSTITUTE OF TECHNOLOGY, Pasadena, Cal11.

Inquiries concerning the following five projects (Nos. 1269 to 830 , 1ncl.) should be addressed to Prof. Robert T. Knapp, Calffornia Inst1tute of Technology, Pasadena, Cal1f.

(1269) HYDRAULIC DESIGN OF BAFTLE TYPE ENERGY DISSIPATORS FOR PIPE OUTLETB.

(b) Research Division, Soll Conservation Service, U. S. Dept. of Agrioulture. 
(o) V. A. Vanonl, J. T. Rostron.

(e) Experimental project.

(f) To obtaln general design formulas for a plpe outlet etructure.

(h) Completed.

(1) Baffle type energy dissipators for pipe outlets." Vito A. Vanon1 and James T. Rostron. Agricultural Englneering, Vol. 25, Mos, 8, 9: 301-304. August 1944. 341,348. September 1944 .

(822) STUDY OF EFFECT OF AIR CONTENT ON CAVITATION PERFORUANCE OF CENTRIFUGAL PUNPS.

(b) Laboratory project. (c) Th. von Kármán, R. T. Knapp, R. L. Daugherty.

(h) This investigation has been completed and the results included in offlco reports.

(827) DETERMINATION OF BOTH AVERAGE AND INSTANTANEOUS VELOCITY AND PRESSURE DISTRIBUTIONG IN THE VOLUTE OF A CENTRIFUGAL PUMP.

(b) Hydraulic Machinery Laboratory Research Program.

(o) Th, von Kármán, R. T. Knapp, R. L. Daugherty.

(e) Experimental project.

(1) Experimental verifleation of the llow characteristics in the pump volute.

(B) By means of a precision dual slide valve and special differential gaugo, ingtantanoous reading of veloolty and pressure are obtained. Their correlation with the average distributions furnish an experimental bas1s for an analytioal examination of centrifugal pump performanoe.

(h) A series of Investigations has been completed and the results sumarized in an opflce report.

(829) COMPILATION OF COMPLETE CHARACTERISTIC PERFORMANCE OF CENTRIFUGAL PUMPS OF VARIOUS TYPES AND SPECIEIC SPEEDB.

(b) Hyäraul1c Machinery Laboratory Research Program.

(c) Th. von Kármán, R. T. Knapp, R. L. Daugherty.

(e) General laboratory investigation.

(h) The project has been completed within a narrow range of specific speeds. The projeot is being discontinued for the present.

(830) AN EVALUATION OF STEPS NECESSARY IN ANALYTICAL REDUCTION OF DATA OBTAINED FROM PRECISION TESTS OF HYDRAULIC MACHINES.

(b) Hydraul1c Machinery Laboratory Research Program.

(c) Th. von Kármán, Robert T. Knapp, R. L. Daugherty.

(o) Laboratory research project.

(1) Refinements in testing equipment and technique require that thorough attention be given to method of evaluation, including determination of physical constants, 11 all the advantages of precision tests are to be obtalned. Information wa collected and analytical methode developed for use in the Hydraulic Machinery Laboratory which are thought to be of general interest and 1mportance.

(h) The otudy has been completed and the results inoluded in a laboratory report.

UNIVERSITY OF CAIIFORNIA, College of Engineering, Fluid Mechenics Laboratory, Berkoley 4, Cal1?.

Inquirles concerning the lollowing flvo projects should bo addregsed to the Chalman, Department of Engineering, Un1versity of California, Berkeley 4 , Cal11.

ARROYO SECO DEBRIS BARRIERS.

(b) Forest servioe, U. S. Dept. of Agriculture.

(a) M. P. O'Brien, J.W. Johnson, K. J. Bermel.

(e) Experimental investigation for design purposes. 


$$
\text { U. of Cal. }
$$

(e) To obtain information on the best crest design to obtain proper operation, on protection of the downetream bed from scour, on the approxdmate debris slope that would occur when the debris basing were completely fllled, and on the protection of banks at certain localities in the Arroyo Seco Canyon.

(g) Modela of two leacher of the Arroyo Seco Canyon near Paadena were construeted to a 1:50 scale and varloue proposed barrlers and barrler systems were invest1gated for the above-mentloned factora.

(h) Project completed. Four reports and two publications have been made.

(1) Reporta on Arroyo Seco Debrle Barriers:

Vol. I. "Brown Canyon debrig bae1n and barrier." K. J. Bermel and R. L. Sanks. 1943.

Vol. II. "Brown Canyon and welr debrla baslns and barrlers." K. J. Bermel. August 1945.

Vol. III. "Report on low and intermediate barriers in the weir barrier reach." G. R. Loucks. August 1945.

Vol. IV. "Report on bank protections." W. U. Garstka. May 1945.

"Movement and deposition of sediment in the vicinity of debris barriers." J.W. Johnson and W. L. Minaicer. Trans. Amerloan Geophysical Union, Pt. V: 901. Apr11 1945.

Model study of Brown Canyon debrie barrler." $\mathrm{K}$. J. Bermel and R. L. Sanks. Proc. A.S.C.E., Vol. 72, No. 5: 613. May 1946.

(1045) UNIDIRECTIONAL, TRANSIENT FLOW OF COMPRESSIBLE FLUIDS IN POROUS MEDIA.

(b) Laboratory project.

(c) J.A. Putnam.

(e) Experimental and theoretical 1nvestigation; PhD. thesis。

(f) To determine the transient behavior of pressure surges resulting from varloue InItlal boundary conditions and to determine the nature of the theoretical solution of the non-linear second degree differential equation deeoribing this and almilar phenomena.

(g) A linear, unlformly-packed, eand column was charged w1th air at an elevated pressure. The pressure at one end was then auddenly reduced to atmospher 10 and preesure-time historles recorded at varlous positions along the tube. The experiments were repeated by suddenly apply1ng alr at elevated pressure at one end of the column when $1 t$ was inltially at atmoepheric pressure.

(h) Project completed. Publicatione planned.

(1) Unidirection, transient flow of compressible flulds in porous media." J. A. Putnam. Ph.D. thes18, 1943.

THE SHAPE OF SMALL DROPS WHILE EVAPORATING.
(b) Laboratory project.
(c) P. C. Nelson.
(e) Graduate thesis.

(f) Bart of a projected general experimental study of natural aerosols; the1r dietribution of $812 \theta$ of particles; their optioal propert1es; and thelr meteorological characterietics.

(g) Fog particle elze obtained by allowing particles to settle on microsoope cover glass slides coated with cellulose-nitrate. Photo micrographs were taken from below during collection. Size of orlginal dropg were obtalned from measurement of contact area and relations determined by this atudy on shape of sesslle water drops.

(h) Project completed.

(1) "The shape of amall drops whlle evaporating from cellulose-nitrate-coated surface, and $1 \mathrm{ta}$ application to the s1ze and size-dietribution of natiral fogs in the San Franolsco Bay Reg1on." P. C. Nelson. M.S. thea18, 1945.

UNDERFLN AND UPLIFT PRESSURE FOR DANS AND WEIRS ON POROUS MEDIA BY ELECTRIC ANALOGY.
(b) Laboratory researoh.
(o) M. A. Sel1m.
(e) Graduate thesis.

(P) To obtain experimental data for design purposes.

(g) Flow nets for various arrengemenis of cut-off walls wore made in the electric analogy tank. 
(b) Work completed.

(1) Hunderflow and uplift pressure for dams and weirs on porous media by eleotric analogy." M. A. Sel1m. Ph.D. thes1s, 1941.

"Upl11t pressure on dams." M. A. Sel1m. Proc.A.S.C.E. December 1945.

(801) FRICTION LOSSES IN ANGULAR-CONTACT THRUST BEARING8.

The following report has been published:

"Friction torque in ball and roller bearings." (A discussion by raakon styri.) Weller Johnson. Mechanlcal Englneering, Vol. 63, No. 10: 738. October 1941.

AIR AND GAS LIFTS.

R. V. H1ggine. 1943.

This thes 1s was a study of existing 11 terature on alr and gas 11fts. Partlcular emphasis was placed on the alr-water lift data for the development of a graphical method for performance prediction in terms of dimensionless rat10s. Predictions were made by this method of oll-well performanco with different gas:011 rat10s. (Thesis in typed form only.)

THE CAS IIFT.

H. E. M1ller. 1942 .

An experimental investigation of an alr-water lift with a transparent 1-1nch diameter eductor plpe was made. Use of a detergent to reduce aurface tension produced depinite changes in the operat1ng characterlst1cs of the 111t. The regults were limited to studies in the range of liquid annuiar sing formation. (Thesis in typed form only.)

MISCELLANEOUS PUBLICATIUNS.

"Laboretory manual (Fluld Nechan10a Laboratory)." R. G. Folsom and E. H. Taylor. University of Callfornia Press. 1942.

"Theses and reports on Plu1d mechanics and related flelds, 1900-1945." Comp1led by J.W. Johnson. October 1945. M1meographed.

CARNEGIE INSTITUTE OF TECHNOLOGY, Department of C1v1l Engineering, Sohenley Park, P1ttsburgh 13, Pa.

Inquirles concerning the following two projeots should be addressed to

Prof. F. T. Mav1s, Head, C1v11 Englneering Dept., Carnegie Inst1tute of

Technology, P1ttsburgh i3, Pa.

EFFECT OF SUBMERGENCE ON SHARP-CRESTED WEIRS.

(b) Laboratory project. (c) F. T. Nav1s, K. C. Thomas. (e) Graduate thesis.

(f) To study effect of submergence on the discharge of sharp-crested weirs.

(g) Tests were conducted for rectangular, parabol1c, triangular, and elroular sharp-crested weirs.

(h) Completed; thesis completed.

SUBMERGED FLOW INVESTIGATION OF SUTRO WEIR.

(b) Laboratory project.

(c) F. W. Edwards, S. O. Lyons, W. W. Stuart.

(e) Undergraduate thesis.

(f) To analyze experimentally the effects of submergence on a sutro welr.

(g) Tests were conducted for both free and submerged discharge.

(h) Completed; thesis completed. 
COLORADO A \& M COLLEGE, CIvil Engineering Department, Fort Collins, Colo.

GROUND-WATER SUPPLY OF PROSPECT VALLEY, COLORADO.

W. E. Code, Colorado Agricultural Experiment Btation Teohnioal Bulletin 34. 40 pp. October 1945.

Prospect Valley 18 in northeastern Colorado and has an irrigated area of about 12,500 acres. Water was 11rst applied to the land in 1912, whioh was carried through canals of a system of which 1 t 18 a part. Inadequate water supplies led to ground-water development as a means of relief in 1933. Favorable conditions existed for obtalning 1rrigation wells over a large part of the Valley and by 1944, 87 suoh wells were being pumped. The water table receded a maximum of 20 feet by 1941, but experienced a substantial recovery during the following three years. The 1nvestigation covered the perlod 1942, 1943, and 1944, although some data were avallable from the beginning of pumping.

The ohanging position of the water table during the investigation was determined from measurements in 63 observation wells. Gross volumetrio ohanges were oalculated and from the measured withdrawal by pumps and reoharge from irrigation and other souroes, a spec1flo jleld of about 17 percent was determined. The data made it poselble to compute the conditions of water supply required for equilibrium and the probable rate of deoline for nonequilibrium conditions. The conolusion arrived at was that when the average gravity supply was 5000 acre-leet, the quantity removed by pumping should not exoeed 9,900 aore-peet.

THE USE OF CURRENT METERS IN MEASURING PIPE DISCHARGES.

Carl Rohwer, Colorado Agrioultural Experiment Station Technioal Bulletin 29.

$40 \mathrm{pp}$. September 1942 .

Hoff and ott ourrent meters were employed to measure the plow in $4,5,6,8$, 10, and 12-1nch atandard $\mathrm{p} 1 \mathrm{pe}$ and 7,8 , and 9-1nch OD p1pe. The apparent discharge so obtalned was chooked against msasurements made w1th a Ventur1 meter and weirs. A comparison of the results made it possible to determine the equation $Q=(419 A-5) \nabla$ in which $Q$ is $1 \mathrm{n}$ gollons per minute, $A$ is the pipe area in square feot, and $V$ is the measured volocity in feet per second.

An analysis of the data shows errors of less than 5 percent for 92 percent of the tests. Errors exceeding 5 percent were largely attributed to velocItles hlgher than recommended for a rubber propeller and to the use of short pipes attached to an elbow.

Any propeller meter can be used for this method of measurement, but the propeller must be protected with a guard. A standard meter rating vith the guard attached is necessary. The technique in traversing the pipe must follow that used in the laboratory work. P1pes must be flowing full at the point of propeller locations and velocities over 9 Ips with the rubber propeller of the ott meter should be avolded.

CORNELL UNIVERSITY, College of Engineering, Ithaca, New York.

Inquiries concerning the pollowing two projects should be adaressed to

Prof. E. W. Sohoder, College of Englneering, Cornell Univeralty, Ithaca, N. Y.

FLOW IN CIRCULAR PIPES PARTLY FULL.

(b) Laboratory research; master's thesis.

(c) M. J. W11118.

(e) To test validity of the commonly assumed variations of "hydraulic elements" with depth.

(g) A 12-1nch plpe 40 feet long with access slots cut along the top, and arranged to glve slopes up to 0.15 , provided with a special entry nozzle to create stable velocity for a given depth and slope, and equipped with two types of plezometers as well as point gages.

(h) Thesis completed.

(1) Short paper in preparation. Further experimental atudy 18 ouggested by 
cortaln Peatures in common w1th Project No. 1242, "Steel open channels", and Project No. 1243, Velocity a1stribution in open ohannels", reported in Vol. IX, Januery 1941.

FLOW IN OPEN CHANNELS WITH ARTIFICIAL ROUGHENING.

(b) Laboratory researoh; Ph.D. thesis.

(c) Hisuan Kuo.

(i) To help towards classiflcation of surface roughness.

(g) Using three $90^{\circ} \mathrm{V}$-shaped wooden $\mathrm{Plumes} 28$ feet long, at flrst wlih smooth varnished surfaces, then progressively roughened with projecting heads of brass escutcheon pins, the shape closely resembling atandard steel rivet heads. The averag'e diameters of the three sizes of round brass heads used were $0.0627,0.01138$, and 0.2228 inches, and the average helghts above the smooth surface of the plume were $0.0233,0.0429$, and 0.0835 inches, regpectively, approximately in one-two-pour relative 81208 . The conter to center spacings used were twelve, six, and three t1mes the diameters of the heads, arrangement being in staggered (equilateral triangular) pattern. Water depths ranged Prom 0.02 to 0.50 loot, slopes Irom 0.005 to 0.09 .

(b) Thesis completed. Short paper in preparation.

UNIVERSTYY OF ILLINOIS, College of Eng1neering, Urbena, III.

THE BACKWATER PROFILE FOR STEADY FLOW IN A RECTANGULAR CHANNEL AND ITS SIGNIFICANCE IN THE STAGE - FALL - DISCHARAE RELATION.

(b) Laboratory problem. (c) E. G. Barron, W. D. Mitchell, W. M. Lansford.

(d) Prof. F. B. Seely, Head, Dept. of Theoretical and Applied Mechanlcs, 214 Talbot Laboratory, University of Illino1s, Urbana, Ill.

(e) This laboratory problem developed into master's theses for Mr. Barron and Mr. Mitchell under the direction of Prop. Lansford. The project was experimental. General information was obtained.

(f) To obtain data on backwater surfaces.

(g) A rectangular channel 5 peet by 5 seet by approximately 163 feet with wooden floor and concrete slde wallo was uged. Art1Pl019l roughness was used on floor only and on floor and side walls to obtain dosirad value of "nt. A slope of 0.003 was used.

(h) Theses completed and on flie in UnIversity 11brary.

STATE UNIVEREITY OF IOWA, Iowa Inst1tute of Hydraul10 Research, Iowa C1ty, Iowa.

(1025) STUDY OF EQUIPMENT AND TECHNIQUE FOR SUSPENDED SEDIMENT SAMPLING AND ANALYSIS.

(b) Cooperative project, U. S. Depts. op War, Interlor, Agriculture, Tenneasoo Vallog Author1ty, and Iowa Inst1tute of Hydral1c ReBaroh.

(1) Reports publ1shed by the U. S. Englneer, 9t. Paul D1gtrict subopplce at the Hydraulios Laboratory. Iowa City, Iowa. Liet of reports 18 included under Project No. 194, Corps or Englneers, Bt. Paul D1striot.

\section{GRADUATE THESES}

An experimental study of the flow of vater through transition in rectangular open channels." G. B. Lyon. M.B., February 1942. "The removal of alr from plpelines by flowling water." 9. H. BIIse. M.S., May
1942 .

"A study of possible extenglone of the Hual River Plood control plan." P. F. Chu. M.S., July 1942 .

"EPpect of aeration rates upon discharge over a sharp-orested weir." C. C. Lomax, Jx. M.S., February 1942. 
"Ground water flow in Rap1d Oreek watershed." M. L. Albertson. M.S., July 1942. "Comparison of model and prototype performance of two Miamd Conservancy District retarding basin st1lling pools." J. D. Lee. M.S., May 1942.

"A study of transpo.
Ph. D., July 1943.

Measurements of veloolty distribution around a stationary shlp model in flowing hater." W. S. Ham1lton. Ph.D., Deoember 1943.

"A study of stream meanders," D. Escobar E. M.S., Apr11 1944.

"Roller type st1lilng act1on." H. W. Feldt. M.8., August 1945.

Experimental study of the free overfall as a function of the Froude number." J. M. Montana. M.S., Apr11 1945.

"A atudy of a method for computing oediment deposits in retarding basins." B. Le1. M.S., February 1946 .

"Esfeot of vacuum on free nappo." L. A. Thorseen. M.S., June 1946.

"Control of the hydraul10 jump by 1116." J.W. Foreter and R. A. Skrindo. M.S., February 1947.

"Di.atribution of veloolty in turbulent jets of a1r." Y.B. Da1. M.B., February 1947.

"An experimental study on baokweter curves.". H. H. Hu. M.S., Mebruary 1947. "An experimental study of the boundary influenoe on the motion of falling spheres." H.-M. Lee. M.S., February 1947.

STAFF PUBLICATIONS.

"Froceedings of the Second Hydraulics Conference", edited by J. W. Howe and H. Rouse. University of Iowa Studies in Englneering, Bulietin 27. 1943.

"The Iowa Inst1tute of Hydraul1c Research". Unlversity of Iowa Studies in Englneering, Bulletin 30. 1946.

"Proceedings of the Thlrd Hydraul1cs Conference", edited by J.W. Howe and J. S. McNown. Un1versity of Iowa Studies in Englneering. 1947.

"Evaluation of boundary roughness". H. Rouse. Procaedings of the Second Hydraulics Conference. Un1versity of Iowa Studies in Englneering, Bulletin 27. 1943.

"A general stablitty Index for Llow near plane boundar1es." H. Rouse. Journal of the Aeronatioal Sclenoos, Vol. 12, No. 4. October 1945.

"Elemantary mechanlcs of flu1ds." H. Rouse. W1ley, 1946.

"Use of the lov-veloclty air tunnel in hydraullc research." H. Rouse. Proceed1ngs of the Third Hydraulics Conference. 1946.

"Gravitational diffusion from a boundary source in two-dimensional flou." H. Rouse. Proceedings of the S1xth Internatlonal Congress for Applled Mechanlcs, Par18. 1946.

"Measurement of sediment transportation." E. W. Lane. Proceedings of the second Hydreulics Conference. University of Iowa. Studies in Engineering, Bulletin 27. 1943.

"Tho effect of cutting off bends in rivers." E. W. Lane. Proceedings of the Third Hydraulics Conference. 1946.

"EfPects of channel shape 1088 s in canal bend." C. H. Yen and J. W. Howe. C1vil Engineering. January 1942.

"Characterlatlce of high-veloclty gets." J.W. Howe and C. J. Posey. Prooeed1ngs of the Third Hydraulics Conference. 1946.

"Criteria for determining sand transport by surfacs creep and saltation." A. A. Kalinste. Trans. American Geophysical Union. 1942.

"Role of turbulence in river hydraul1c8." A. A. Kalinske. Proceedings of the Second Hydraulics Conference. Unlversity of Iows Studies in Englneering, Burletin 27. 1943.

"Air entrelnment in closed condult plow." A. A. Kalinske and J. M. Robertson. Trans.A.S.C.E., Vol. 108: 1435. 1943. 
"Experiments on eddy diffusion and suspended materlal transportation in open channels." A. A. Kalinske and C. L. Plen. Trans. American Geophysical Union: 531. 1943.

"Removal of alr erom pipe lines by flowing water." A. A. Kalinske and P. H. B1188. C1711 Engineering. Ootober 1943.

"Eddy diffusion." A. A. Kalinske and C. L. Plen. Industriel and Eng1neering Chemistry, Vol. 36: 220. 1944.

"Design and operation of grease interceptors." A. A. Kalinske and F. M. Dawson. Sewage Works Journal, Vol. 16. 1944.

"Study of transportation of pine sediments by flowing water." A. A. Kal1nsko and C. H. Heia. University of Iowa Studies in Eng1neer1ng, Bulletin 29. 1945. "Conversion of kinetio to potential energy in plow expansion." A. A. Kalineke. Proc. A.S.C.E.: 1545. December 1944.

"Application of statistical theory to veloolty and suspended sediment measurement in river 8." A. A. Kalingke. Trans. American Geophy 1 cal Union. 1945.

"Problems and solutions and questions and answers for Rouse: Elementary mechanios of Plulds." J. S. MeNown. Wliv, 1946.

"Pressure distribution and caritation on submerged boundar1es." J. S. MoNown. Prooeedings of the Third Hydraul1cs Conference. 1946.

\section{REPORTS ON WARTIME RESEARCH PROJECTS.}

"Sorle model studies of the movement of emoke and gas olouds." Hunter Roure. NDRC Informal Report No. 10.3A-36. October 10, 1943.

"Wind-tunnel studies of the diffusion of heat from a Ilne source." Hunter Rouse, M. L. Albertion, R. A. Jensen, and C. F. Schadt. NDRC Informal Report No. 10.2-12. March 18, 1944.

"Fog-a1spersel. recommendations for the Island of ...... H. Rouse, M. L. Albertson, R. A. Jensen, and C. F. Sohadt. Informal Report to the NDRC. December 1944. "The Iowa radiant burner." H. O. Cropt and J. M. Trummel. Informal Report to the NDRO. Apr11 30, 1945.

"Development of a fog-d1spersal burner for gasoline and fuel 011." M. L. Albertson. Informal Report to the NDRC. June 15, 1945.

"wind-tunnel studies of the diffusion of heat by olngle wind curtains and baffles." H. Rouse, M. L. Albertson, R. A. Jensen, and C. F. Sohadt. NDRC Formal Report No. 4334. November 11, 1944.

"Wind-curtain Installations for fog dispersal." R. A. Jensen. Inpormal Report to the NDRC. Suly $16,1945$.

"Wind-tunnel studies of the diffusion of gas in sohematic uriban districte." H. Rouse, M. L. Albertson, R. A. Jensen, and C. F. Sohadt. NDRC Informal Report No. 10.3A-46. May 9, 1944.

"Diffusion of smoke and gas by wind." Motion picture prepared for the Chemloal Warfare Service by the Iowa Inst1tute of Hydrallc Research through DIv1s1on 10 of the NDRC.

"W1nd-tunnel studies of gas diffusion in a typloal Japanese urban district." A. A. Kalinske, R. A. Jensen, and C. F. Schadt. NDRC Informal Roport No. 10.3A48. June 8,1945 .

"Correlation of wind-tunnel studies with fleld measurements of gas diffusion." A. A. Kalingke, R. A. Jensen, and C. F. Schadt. NDRC Informal Report No. 10.3A48a. September 29, 1945.

"Preliminary wind-tunnel studies on als flow over monntainoug terrain." A. A. Kalinske, R. A. Jensen, and C. F. Schadt. Informal Report to the NDRC. July 25, 1945.

"Description of 10-foot channel and appurtenances for tests on stationary shlp models in Plowing water." Iowa Inst1tute of Hydrallo Research. Report No. 1 to the Dav1d Taylor Model Basin, Bureau of Sh1p日, U. S. Navy. July 29, 1942.

"Test of a stationary ship model in a 10-poot channel." Iosa Institute of Hydraul10 Research. Report No. 2, DTMB. December 14, 1942.

"Test of a stationary ship model in a 16-foot channel." Iowa Institute of $\mathrm{Hy}=$ draul10 Research. Report No. 3, DTMB. May 5, 1943. 
"Testa of atationary shlp models in a 16-foot channel." Iowa Institute of Hydraul1c Research. Report No. 4, DTMB. November 15, 1943.

"Reslatance testa on ship model and friction plane in 16-foot and 1l-poot channels." Iowa Inst1tute of Hydraul1c Research. Report No. 5, DTMB. July $30,1945$.

"Cavitation tests in the Iowa variable pressure water tunnel." H. Rouse, J. $\mathrm{s}$.

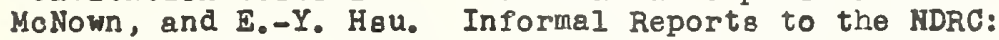

"Tunnel characteristics and test procedure for bodies of revolution." November 30,1944 .

"Cylindrical body with hemiapherical head." December 4, 1944.

"Cylindrical body with blunt head." December 8, 1944.

"Cavitation teste on a systemat1c series of torpedo heads." H. Rouse, J. 8. HoNown, E. $-Y$, Hau, and C. A. Lamb. Informal Reports to NDRC and DTMB:

"Water tunnel characterlet1ce and test procedure." NDRC. February 22, 1945.

"Hemlapher1cal head." NDRC. February 28, 1945.

"Blunt head." NDRC. March 5, 1945.

"1/4-cal1ber rounded boad." NDRC. March 10, 1945.

"1/8-cal1.ber rounded head." NDRC. March 15, 1945.

"l-callber og1val head." NDRC. March 20, 1945.

"2-callber og1val hoad." NDRC. Maroh 26, 1945.

$" 45^{\circ}$ conlcal head." DTMB. June 1945.

"90 conlcal head." DTMB. June 1945.

" $135^{\circ}$ concave conlcal head." DTMB. June 1945.

"2:1 ell1peoldal head." DTMB. July 1945.

"I:2 ell1psoldal hoad." DTMB. July 1945.

"l:2 concave ell1peoldal head." DTMB. July 1945.

"Hollow cylindrical head." DTMB. August 1945.

"Summary of cavitation tests on a systematic series of rounded torpedo heads." H. Rouse, J. B. MoNown, and E.-Y. Hau. Informal Report to NDRC. MaJ $31,1945$.

"Summary of cav1tation tests on a systematio serles of ell1peoldal torpedo hoads." H. Rouse, J. S. McNown, E. - . Heu, and C. A. Lamb. Report to DTMB. Ootober 1945. "Summary of cavitation testa on a systematic serles of conlcal torpedo heada." J. 8. MoNown, E.-Y. Heu, and C. A. Lamb. Report to DTMB. November 1945.

"Summary of cavitation teats on modipled hemiepherical heads." J. S. MoNown, E.-Y. Hau, and C. L. Lamb. Report to DTMB. January 1946.

"Cavitation teets on a half-body torpedo head." J. S. McNown, E.-Y, Hsu, and C. A. Lamb. Report to DTMB. Apr11 1946.

"Flre-mon1tor 1nvestigation." J. W. Howe and C. J. Posey, w1th M. L. Albertson, J. R. Barton, and E. M. Laursen. Prel1minary report to DTMB. October 1945.

"Review of experimental and theoretical studies of plow behind grids." J. $\mathrm{g}$. MoNown and M. L. Albertion. Informal report to DTMB. October 1945.

LEMIGH UNIVER8ITY, Department of C1V1l Englneering, Bethlehem, Pa. THE INFLUENCE OF VISCOSITY ON CENTRIFUGAL PUMP PERFORMANCE.

Arthur T. Ippen. A.S.M.E. Paper No. A-45-57. November 1945.

THE EFFECT OF LATERAL CONTRACTIONS ON BUPERCRITICAL FLOW IN OPEN CHANNELS.

John Howard Dawson, Master's thesis, Leh1gh Un1versity. 1943.

Theoretical and experimental etudy, shows advantages of abrupt corners in such transitione for particular velocities. 
104

LOUISIANA STATE UNIVERSITY AND A \& M COLLEGE, Dept. of Hydraul1c Engineering, Univeraity station, Baton Rouge 3, La.

(28) HYDROLOGICAL STUDY OF CITY PARK LAKE DRAINAGE AREA.

(224) FACTORS AFFECTING THE EVAPORATION FROM A LAND PAN.

(225) COMPARISON OF EVAPORATION BETWEEN A LAND PAN AND A FLOATING PAN.

The above three projeots have been completed, written up, and publishod as an Eng1neering Experiment Station Bulletin of Loulsiana state University, under the following title:

"A sumary of hydrologic data, Bayou Duplantier Watershed, 1933-1939."

Gien N. Cox. Studies in Englneering, No. 5. 1940.

UNIVERSITY OF MINNESOTA, St. Anthony Falls Hydraul10 Laboratory, M1nneapol18 14, Minn。

MODELS FOR STUDY OF SPILLWAY STRUCTURES FOR PROPOSED SAN JACINTO RIVER DAM.

(b) City of Houston, Tex. (c) L. G. Straub, A. G. Anderson, W. W. DeLapp.

(d) Dr. Lorenz G. Straub, Director, St. Anthony Falls Hydraulic Laboratory, Minneapol18 14, Minn.

(e) Experimental model study.

(P) To establish hydraul10 design of splliway and operational procedure.

(g) Section models bu1lt to scales of 1:55 and $1: 15$ used to study flow and erosion patterns for complete range of discharges. Section models and threedimensional models to scele of $1: 55$ used to design low water aplllway section and establish operating procedure.

(h) Completed; report submitted to City of Houston.

OUTLET FOR CULVERTS AND CHUTES.

(b) D1v181on of Dralnage and Water Control, Soll Conservation Service, U. S. Dept. of Agriculture, in cooperation with Minnesota Agricultural Experiment station.

(c) F. W. Blalsdell.

(d) Fred W. Blalsdell, Soll Conservation Service, St. Anthony Falls Hydraulic Laboratory, Minneapolis 14, Minn.

(e) To develop a generallzed design.

(1) To develop an outlet whose performance can be predicted without recourse to Purther model study.

(g) Outlet developed for Froude numbers of three or greater. Design 18 based on hydraulic jump with the proportions of the stilling basin determined experimentally.

(h) Project completed.

(1) Outlet developed has been named "The SAF st1li1ng Basin". "Tests of a standerd oulvert outlet for use with drop inlet culverts." F. W. Bla1sdell. October 1941.

"Tests of culvert and Plume outlet structures." Supplemental report on tests of culvert and flume outlet structures. F. W. Blalsdell. December 1942 and December 1943.

"The SAF st1ll1ng bas1n." F. W. Bla1sdell. December 1943. (Above publications avallable for loan.)

MODII TESTS OF OUTLET BTRUCTURE, LOWER CANEY LAKE, MINDEN, LOUISIANA.

(b) Region Four Englneering D1vision, So1l Conservation Service, Ft. Worth, Tex.

(c) F. W. Bla1sdell.

(d) Fred W. Blalsdell, Soll Conservation Service, St. Anthony Falls Hydraul10 Laboratory, Minneapol1s 14, Minn.

(e) To obtain data for design purposes.

(P) To check the design. 
(g) A 1:9 Lucite model of the transition and SAF otilling basin were tested with a movable bed channel, and desirable modifications of the trangition and wingwall design were made.

(h) Study completed.

(1) "Report on hydraulic model tests of outlet structure to be bullt at Loner Caney Lake, Minden, Loulslana." F. W. Blalsdell. September 1945. (Available for loan.)

TEST OF AN AUTOMATIC DRAINAGE GATE.

(b) Division of Drainage and Water Control, Soll Congervation Service, U. S. Dept. of Agriculture, in cooperation with Minnesota Agricultural Experiment Station.

(c) S. H. Anderson.

(d) Fred W. Bla1sdell, Soll Conservation Service, St. Anthony Falls Hydraulio Laboratory, Minneapolis 14, Minn.

(e) To obtain data for design purposes.

(P) To determine performance and check design.

(g) Operation of gate 18 based on the principle that the center of preseure occurs at two-thirds the depth. A wooden gate 3-1/2 feet wide by 5 leet high was tested in a channel 9 leet wlde by 6 peot doep. Teats resulted in an improved design.

(b) Project completed.

(1) Meport on a test of an automatlc dralnage gate." S. H. Anderson. August 1945. (Ava1lable for loan.)

NEWPORT NEWS SHIPBUILDING AND DRY DOCK COMPANY, Newport New日, Va.

Inquiries concerning the following eleven projects should be addresed to

Mr. C. H. Hancock, Hydraulic Laboratory and Shlp Model Testing Basin, Newport

News Sh1pbulld1ng and Dry Dock Company, Newport News, Va.

STRUT BEARING TEST.

(b) Eng1ne Technical Dept., Nowport News Shipbuila1ng and Dry Dock Company.

(c) W. F. Taylor, K. S. Black.

(e) Experimental, design data.

(f) To obtain design data and improve the water passages for inducing circulation in water lubrlcated rubber atrut and outboard propeller ahaft boarings.

(g) Model scoops were tested at varlous velocities in a closed test ohannel to determine the induced head for varloug quantitieg of flow through the shart bearing scoop. Shaft remained stationary in these tests.

(h) Completed.

DECK EDGE ELEVATOR TESTS.

(b) Engine Technical Dept., Newport News Sh1pbullaing and Dry Dock Company.

(c) W. F. Taylor, J.R. Kane, R. I. Noland. (e) Experimental, design data.

(f) To study the dynamic porces on a deck edge elevator platform heeled into the crest of a wave, both with and without protecting sponsons forward to obtain structural design data.

(g) Model deck edge elevator placed at an angle in an open test channel and forces measured with a $81 x$ component dynamometer.

(h) Completed.

PARAVANE SHOE TESTS.

(b) Hull Technical Dept., Newport News Shlpbullding and Dry Dock Company.

(c) S. B. Besse.

(e) Experimental and design.

(P) To design an inclined plane type of paravane shoo that wild use the dynamic 
foroes around the bow of a shlp to lower 1 teelf while the shlp 1s under way.

(g) A model of the forward part of a ship was f1xed in a channel of moving vater. Model paravano shoes were tosted at varlous otream veloo1t1es.

(b) Completed.

(1) Paper before the Fourth Annual Amerloan Tow1ng Tank Conference. Transaotions of the Soclety of Naval Arohiteots and Marine Engineers, Vol. 49. 1941.

CONDENSER SCOOP TESTS.

(b) Eng1ne Technical Dept., Newport News Shipbuilaing and Dry Dock Company.

(o) W. F. Taylor, B. R. Loe. (o) Experimental, design data.

(1) Obta1n design data and 1mprove the efflcienoy of oondenser olrculation scoops for ohlps.

(g) Model scoops were tested in a closed channel and tho induoed heads vo flow through sooop determined. A oultable boundary layer was created by roughening the wall of the ohannel ahead of the scoop models.

(h) Closed.

(1) "Condenser scoop des1gn." E. F. Hew1ns and J. R. Re111y. Trang. Soolety of Naval Archltects and Marine Englneers, Vol. 48: 277-297. 1940.

NOZZLE TESTS FOR AMIUNITION STOWAGH ROOMB.

(b) Eng1ne Technioal Dept., Newport News shipbuilding and Dry Dook Company.

(o) W. F. Taylor, B. R. Loe. (e) Experimental, for design information.

(1) Investigation of four spray nozzles to determine thelr ab1l1ty to wet down and thus cool a ship's ammunition stowage room.

(g) Area covered by water from nozzle spraying on a glass plate from beneath determined at various pressures and quantities of water and various nozze distanoes from the glass.

(h) Completed.

DECK EDGE ELEVATOR TEST.

(b) Hull Technlcal Dept., Newport News Shlpbullding and Dry Dock Company.

(o) W. F. Taylor.

(e) Experimental, design data.

(e) To 1nvertigate qualitatively the tendenoy, if any, of a deok odge elevator platform to oave a shlp to heel, when the platform 18 momentarily $1 \mathrm{mmersed}$ In a wave creat.

(g) Dynamically balanced ship model f1tted with a model deok edge elevator platform outboard Prom the main deck. Model towed at tow rope pull for designed speed in various sized waves on an even keel and at a $20^{\circ}$ heel, and with the platform inclined $5^{\circ}$ lower fomard.

(h) Completed.

SHIPIS SWIMMING POOL SURGING TEST.

(b) Hull Technical Dept., Newport News shtpbullding and Dry Dook Compeny.

(o) H. F. Taylor, J.F. snyder. (e) Experimental, design data.

(1) To determine experimentally the elflclenoy of wave traps designed to keep the water in the swlmming pool from aplashing on to the deck; to oheok experimentalis a formula for finding the period of surge in rectangular pools of uniform depth; and to 1 nvest1gate the subject of surge in ships swimming pools.

(g) A model of the shlp's swimming pool, complete w1th interchangeable wave traps, was fastenod to a crank and moved to simulate pitching of the ship. Both perlod and amplitude were variable. The formula was ohecked by f1liIng a reotangular tank of varying dimensions with varlous dopths of water and plnding the perlod by counting the surges and by plnding the perlods of osclilation whloh produood synohronism. Varlous deslgns and locations of pools were 1nvestlgated, as well as the effect of false bottoms on the period as giten by the formula.

(h) Completed. 
CARRIER IN WAVES.

(b) Hull Teohnioal Division, Newport News Shipbuilding and Dry Dock Company.

(c) B. R. Lee, K. S. Black. W. C. Madison, W. T. Radcliffe.

(e) Experimental, design probleme.

(f) To investigate water loads on the plight deck of an aircraft oarrier running head on into waves of various lengths.

(g) Dynamically elmilar model towed head on in waves. Results recorded by slow motion piotures.

(h) Completed.

WIUMINGTON LAUNCHING TEST.

(b) North Carolina Shipbullding Corporation, Wilmington, N. C.

(c) R. H. Pepper, P. R. Keffer, Jr., W. F. Taylor.

(e) Experimental, launching data.

(f) To investigate the efflcienoy of varlous drags used to swing shipg into the ohannel during launching and to plot the path that would be taken by the shlp.

(g) Dynamically ballasted model vas towed down one side of the 56-foot model basin and released at a given point. The stern drag then took effect and swung the model around simulating the prototype. A osmera located direotly above the tank photographed a set of intermittent lights. Analyois of the light trace photographs ylelded position, veloolty, and heading, and in soine cases the load on a small dynamometer.

(h) Completed.

RESTRICTED CHANNEI 1.

(b) David Taylor Model Basin, U. S. Navy.

(c) W. F. Taylor, C. C. Garrison, R. H. Pepper. (e) Experimental.

(f) To determine the speed and behavior of selected typical combatant veselo In a canal of a given width and sloping sides.

(g) The models were towed in water at the ecale width and depth. Wave patterns were photographed and trim and elnkage data were taken.

(h) Completed.

(1) These testa were mentioned in Commander E. A. Wright's paper, "A pattern for research in Naval archltecture", read before the Soolety of Naval Archltects and Marine Engineers, 1946.

CARRIER LAUNCHING CLEARANCES.

(b) Hull Teohnloal D171810n, Newport News Shipbuilding and Dry Dock Company.

(c) W. S. Taylor, B. R. Lee, K. S. Blaok. (e) Experimental, launching data.

(f) To find the horizontel olearance of a CVB launched eccentrically.

(g) A dynamically oimilar model was launched from model ways.

(h) Completed.

THE OHIO STATE UNIVERSTY, Department of Mechanical Engineering, Columbus 10, Ohio.

(526) DETERMINATION OF COEFFICIENTS OF DISCHARGE OF FLOW NOZZLES.

(b) Fluid Meter Committee, A.S.M.E.

(d) Prof. S. R. Beltler, Professor of Hydraulic Englneering, The Ohio State University, Columbus 10, Ohio.

(h) Material from tests conducted by committee has been given to Engineering Experiment Station for publication of all data and resulta. Probable date of publication is september 1947. 
PENN81LVANIA WATER \& POWER COMPANY, 1611 Loxington Bullding, Balt1more, Ma.

\section{ON THE USE OF A RADIOACTIVE-TRACER METHOD IN MEASUREMENTS OF WATER.}

\section{V.F. Hess. Trans. Amerlcan Geophysioal Un1on. 1943.}

Work on the tracer method of water measurement was instlated in 1940 when radium was invest1gated as a rad1oactlve tracor. Ion1zation chamber and an eleotrometer were used to measure the woak radium oolut1ons. The lower limlts of conoentretion were ostablished below which proolse measurements were not possible. For testing large turbines, radium as a tracor was lound. to have cerlous IIm1tations.

PURDUE UNIVERSITY, School of C1V1l Eng1neering and Englneoring Mochan10. Lafagette, Ind.

\section{FLOW OF WATER FHROUGH SMALL SWING-CHECK VALVES.}

F. W. Greve, Profegsor of Hydraul10 Engineering, Purdue Un1versity. Eng1neering Experiment station kesearch Sor18 No. 88, Vol. XXVII, Ho. 3. 20 pp. May 1943.

The brase valves, $0.50,0.75,1.0,1.5$, and 2.0 1nchea in size, were teated in the Hydraul1c Laboratory with water sanging in temperature from 67.5 to $74.1 \mathrm{deg} F$. The loss of head remalned almost constant for all valves when the volocity of llow in the plpo to which the valve $a 8$ attached was 1.0 fpo or 1088. With veloo1tles greater than unity, the loat head and the Reynolds number inoreased at a decolorating rate with increase in velooity of plow and deoreased with inoreased 18 igo for a stated velnclty. Apparenty a minimal veloolty of plow botween 5 and $6 \mathrm{fps}$ in a pipe is necessary to maintain the oheck in an aocompanying valve in a wemopen position.

\section{FLOW OF LIQUIDS THROUGH VERTICAL CIRCULAR ORIFICES AND TRIANGULAR WEIRs.}

F. W. Grove, Professor of Hydraulic Eng1neering, Purdue Univerg1ty. Englneer1ng Experiment Station Research Ser1er No. 95, Vol. XXIX, No. 3. 68 pp. May 1945.

All orlf10es and welrs were cut from smooth brass plates, 0.25 incher thick. The upstream edgo of each aperture was square with the inner paos of a plate. Beveling a plate at an angle of $30^{\circ}$ to the plane of an ordflo or a welr made certaln that the osoaping stream touched the boundary of an opening along a line represented by the upotream dge. The diameters of the orlploos were $0.252,0.381,0.502,0.625,0.754,0.875,1.00,1.50$, and 2.001 1nchos, and the oontral anglos of the welre vere 30,60 , and 90 deg. Included among the l1quids used were oylinder 011, furnace o1l, mixtureo of oylinder and Purnace 0118, goap golut1ons, admixture ol DuPont's alkanol and water, suorose solutions, and water. The range in temperature and physical properties of the fluide was a lollow: (a) temperature, 58 to $178 \mathrm{deg} 5 ;$ (b) density, 1.61 to 2.45 slugs/ou st; (o) surpaos tension, 0.00196 to $0.00526 \mathrm{lb} / \mathrm{ft}$; and Inemat1c $10001 \mathrm{ty}, 0.00000391$ to $0.00182 \mathrm{ge} \mathrm{ft} / \mathrm{s} 00$. The range 1n sat10 of hoad to dlameter for the or1P1006 was Prom 0.514 to 27.8 , whlle the smal1oat head on a we1r was 1. 44 1nch and the largest was 6. 48 Inches.

The following oonolusions were deduood within the 11atte of the teat data.

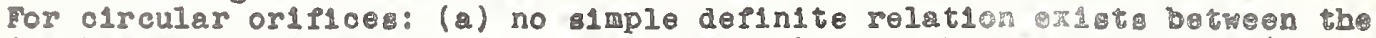
disoharge coefflolent and elther the Reynolds or the weber number; (b) the crltioal, or maximal, dlsoharge corlplolent varlod lege than 2 percent for

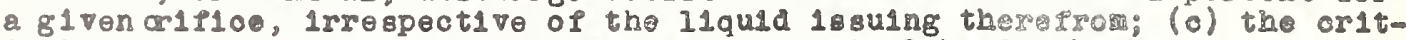
loal discharge coefflclent oocurred at a orltical head, whlch boad wa dependent upon the diameter of the orlfloe and the k1nematso v18cosity of the Pluld; (d) the orlt10al disoharge ooefllolent varled 1nverbely with the

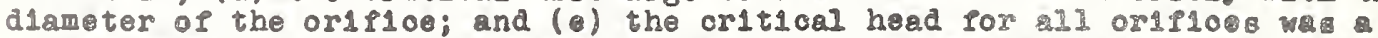

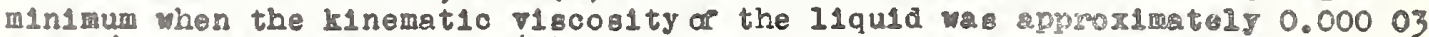
eq It/eoc. For the welrs: (a) the alsoharge coelf101ent decreased th increase in hoad; (b) the data wero insufpiolent to ostabldeis posalble mathemet1oal relation betwoen the disoharge ooelflolent and tho Reynolde number: and (o) the aurace tonolon of a liquid ald not affeot the disoharge coefliolent. 
8. MORGAN SMITH COMPANY, YOTK, Pa.

Inquirles conoerning the following flve projects should be addressed to Mr. George A. Jessop, Ch1ef Eng1neer, S. Morgan Sm1th Company, York, Pa.

SMITH RAPLAN TURBINE. EPFICIENCY, HORSEPOWER, CAVITATION, RUNAWAY SPEED, AND HYDRAULIC THRUST TESTS.

(b) Government of Uruguay, Rio Negro Plant.

(o) R. Sahle and laboratory personnel.

(e) Experimental research.

(1) To determine the horsepower and efflciency of a full-size 8mith-Kaplan turbine to obtaln enough data to compare results over the ent1re range of head Prom 54 It to 110 It head. To detemine the cavitation I1mits, the maximum runaway epeed, and hydraul10 thrust.

(g) Tests wore conduoted on a Sm1th-Kaplan turb1ne. The draft tube, splral casing, and stay vanes had been installed and had boen manufactured by another company. New wheel case parts and runner of S. Morgan Smith Company des1gn were used. Two models wore mado: one 16-1nch diameter for the eff1olenoy and power tests, and one 10-1noh diameter for cav1tation, runaway speod, and hydraulio thrust tests. On both models the blades of the runner were adjustable and tests were made at $81 \pi$ different blade angles. At each blade position, the tests covered a large range of speods and a sufficlent number of gate opening to determine comparat1ve results over the ent1re range of heads. The cavltation teet determined the 11mits of horsepower at all heads whlch can be obtalned in the fleld. Runaway speed was determined for all hesds and values of $81 \mathrm{gma}$.

(b) Testo were completed Soptember 23, 1942.

FRANCIB TYPE REVERSIBLE PUMP AND TURBINE EFFICIENCY, HORSEPOWER, CAVITATION, RUNAWAY SPEED, AND HYDRAULIC THRUST TESTS.

(b) Canadian General Finanoe Companj, Ltd., Bao Paulo Tramay Light and Power Company, Ltd., Pedrelra Pumping Plant No. 5.

(c) R. Sahle and laboratory personnel. (s) Experimental researoh.

(f) To determine the discharge and efplclenoy of a full-alze Francls type reversible impeller when operating as a pump over the entire range of head from $59 \mathrm{ft}$ to $101.7 \mathrm{ft}$ head. To determine the horsepower and efflclenoy when operating as a turbine over the entlre range of head from 59 ft to 98.4 ft head. To determine the cavitation $1101 \mathrm{ts}$, the hydraulio thrust, and runaway speed.

(g) A model was made of a apeclal design spiral casing, elbou draft tube, and wheel case. Tosts were conduoted when operating as a pump and as a turbine over a large range of speeds and sufficlent number of gate openings so that a curve could be drawn to determine the exact opening to produce maximum efplolenoy. The purpose of these tests was to determine the performance of the unit wen operating at a fixed speed, both as a turbine and as a pump. Cavitation tests were made on the same model setting and the value of slgma determined by the usual method. Runaway speed tests were conducted at varlous gate openings. Maximum hydraulio thrust was also obtalned when operating both as a turbine and as a pump.

(h) Tests were completed February 1, 1945.

ADJUSTABLE BLADE BMITH-KAPLAN TURBINE EFFICIENCY, HORSEPOWER, AND CAVITATION TESTS. BIX-BLADE RUNNER DEgIGN.

(b) S. Morgan Smith Company.

(c) R. Sahle and laboratory personnel.

(e) Exporimental researoh.

(f) To determine the efflclenoy, horsepower, and cavitation limits on a sixblade Smith-Kaplan turblne.

(g) Tests were conducted w1th a $81 x$-blade runner, the blades belng adjusted manually. The runner was installed on an elbow draft tube of standard deolgn, and the tests were run in an open flume setting.

(h) Tests were conducted in June 1943. 
ADJUSTABLE BLADE AXIAL FLOW PUMP. EFFICIENCY, HORSEPOWER, AND DISCHARGE TESTS.

(b) David Taylor Model basin, U. 8. Navy.

(c) G. Dugan Johnson and laboratory personnel.

(e) Experimental research.

(f) To determine the discharge, the horsepower, and the efficiency of a full. olze axial flow pump under fleld heads.

(g) A model was made of the suction chamber, discharge tube, two-blade pump impeller, and 1ts casing. Tests were conducted to determine the efficiency, horsepower, and discharge at a number of blade angles and over a sufficlently large range of speed to cover the required proportional speeds as determined by pleld conditions.

(h) Tests were completed March 3, 1942.

ADJUSTABLE BLADE AXIAL FLOW PUMP EFFICIENCY AND DISCHARGE TESTS.

(b) Pusey \& Jones Corporation, Wilmington, Del.

(c) R. Bable and laboratory personnel. (e) Experimental research.

(f) To determine the discharge and efflciency of a full-size axial flow pump under rleld heade.

(g) A complete model of the full-size unit was made and tested. The suction chamber, being of special design, was provided with Lucite windows for observation of the flow conditions. Several sets of guide vanes were installed and results determined. The pump 18 mounted horizontally.

(h) Tests were completed March 11, 1946.

STANFORD UNIVERSITY, School of Engineering, Stanford University, Calif.

(889) CHARACTERISTICS OF BORE WAVES.

Project discontinued.

(890) VARIABLE DISCHARGE OF A RECTANGULAR CHANNEL.

"Varied flow in a rectangular open channel." C. Maclain Adams. Stanford University thesis. 1939. (Avallable by interlibrary loan.)

Within the range of unsteadinses attained with the apparatus built in the laboratory it was found that the various forces so nearly balanced that evaluation of the residual friction term became almost entirely dependent upon the slope of the bottom. It may be concluded therefore that iriction within that range of unsteadiness is probably not appreciably different prom that obtained in steady rlow.

(1019) STEEP SLOPE FLOH PHENOMENA.

"Report on steep slope llow." J. Hedberg. Trans. American Geophysical Union, Pt. I: 74-76. 1942.

Th1s project was discontinued due to the death of Dr. Hedberg. The above report is the last progress report on the project.

(1020) FLOW OF FLUIDS IN FRACTIONATING COLUMNS.

"Characteristics of flow in a Practionating column." C. B. Lusk. Stanford University thesis. 1941. (Avallable by interilbrary loan.)

Fractionating colum operating at the maximum efflclency. For large alr Plow rates, the pressure drop per tray is primarily a function of the design of the notches or perforations around the periphery of the bubble cap, and loss occasloned by the deslgn of the vapor riser and the shape of the bubble cap is quite small in comparison. The increase in pressure arop, as the helght of the overflow weir is ralsed, is directly dependent on the amount of liquid submergence. For any given depth of submergence and water flow rate there seems to be a particular pressure arop for each tray; 11 the water rate remalns the same, but the depth of submergence 18 increased, then this added increment of the total pressure drop varles directly with the inorease in static depth of 11quid submergenoe. 
It vas not poselble to determine the l1quid gradients existing on the tray for varlous oonditions of flow. It seems loglcal to assume, in the absenoe of data to the contrary, that for a given rate of alr flow, liquid gradients increase as the water rate 18 inoreased, and that all liquid gradients should be as low as posilble in order to prevent channeling of vapor flow and to insure that each bubble oap contributes equally to the overall efflolenoy of each fractlonating plate.

The method as indicated 18 applioable for an approximate determination of the helghte to whlch vapor-agltated opray may be carrled under a given set of deslgn conditions. This assumes that the data as derlved for alr and water can bo ut1lized in the computations when the mixture 18 comprised of two or more volat1le hydrocarbons.

(1297) WIND PRESSURES ON SIDES AND TOP OF CYLINDRICAL TANKS.

"An experimental 1nvestigation of wind pressures on cylindrical tanks." A. C. Bardin. Stanford Univeralty theo18. 1943. (Avallable by 1nterlibrary loan.)

Tests on vertical oylindrical tank modele using water in an open channel as the flowing liquid. Resultant force on side of tank found to aot slightly below midpolnt. The top uplift foroe acts at approximately $2 / 5 \mathrm{D}$ from the windward edge of the roof. The top uplift force 1s the resultant of a varyIng pressure distribution, the greatest intensity and the largest pluotuationa ooourring at the windward edge of the roof. By 1napeotion of distr1bution patterns it appears that the maximum lifting pressure intensity (occurring at the windward edge of the roof) can be taken as 1.5 to 2.5 t1mes the average.

UNIVERSITY OF WASHINGTON, Hydraul 1 cs Laboratory, Seattle, Wagh.

FLOW STUDIES FOR TACOMA NARROWS BRIDGE USING BENTONITE SUSPENSION.

Report by Walter F. H1ltner, January 1942. Submltted to Prof. F. B. Farquharson, Dlreotor of Model Studies for the Taooma Narrows Br1dge.

Material Includes st1ll and Kodachrome moving plotures of flow pattern around crose-eection of Tacoma Narrows Brldge a 1ndicated by stream double refraction of Bentonite suspension.

DYNAMIC MODEL OF SEYMOUR NARRONS, BRITISH COLUMBIA.

Report by Walter F. H1ltner, August 1942. Report and model prepared for Br1t1sh Columbla Bridge and Dredging Company, 540 Howe Street, Vancouver, B. C.

study of effects of currents and waves on drilling barge in Seymour Narrows, w1th spec1flc danger areas indicated.

HYDRAULIC MODEL OF HELL'S GATE CANYON, PART ONE, CONSTRUCTION AND CORRELATION TO RIVER.

Edward 8. Pretlous and Walter F. H1ltner, December 30, 1942. Prepared for International Paolflo Balmon Flsherles Commision, Seattle, Wash.

Construction of a model of rocky canyon to reproduoe flow and Inalcate effect of proposed remedial measures. Describes methods of modeling, controlling flow and water levels, and adjusting roughness.

UNIVERSITY OF WISCONSIN, Hydraul1c Laboratory, Mad1son, W18.

Inquirles concerning the following ten projeots should be addressed to

Dr. Arno T. Lenz, Hydraulic Laboratory, University of W18consin, Madion, W1s.

MODEL STUDY OF DISCHARGE CAPACITY OF DU BAY DAM.

(b) Laboratory projoot in cooperation with Consolidated Water Power and Paper Company, W1sconsin Rap1ds, W18. 
(c) C. D. EkIund, A. F. Ingersoll, W. W. Warzyn.

(e) Experimental laboratory study a thes1s for B.S. degree in C1vil Engineering.

(1) To Investigate disoharge capec1ty of talnter gates under varlous conditlons of water elevations and gate openinge, in order to have some means of measuring the discharge of the river at the dam, since construction of the dam llooded the U. S. Geological survey gaging station.

(8) Studies were made, using a 1:30 scale model based on plans for the dam. D1scharge coeflicients were determined for the gates under full and partial openlng and with one or more gates open at a time w1th varlous head-water and ta1l-water elevations. The effect of pler contractions was also studied.

(h) Thesis completed in 1942.

(1) Experimental information was obtained on a subjeot on which there was previous lack of accurate information.

(1300) FLOOD FREQUENCIES OF WISCONSIN RIVERS.

(b) Laboratory project.

(c) P. C. Sodermann, J. O. Wagner.

(e) Thesis study for B.S. degree in C1vil Englneering.

(1) To atudy flood-flow records of Wlsconsin rivers according to Hazen's probab1l1ty analyo1s methods.

(g) Records from 36 Wisconsin gaging statlons were analyzod to determine the coefflclents of flood, variation, and skew. The records were then grouped for four major sections of the state in order to compare the coefflolents from stations within each section. Computed values of the coefficients were compared with the plotted records, and in generel the computed ourves agree well with the plotted points. The ooefflclent of flood was essentlally constant at 1.3 for the large dralnage areas. The coefficlent of varlation พaв reasonably constant and varied consistently for all sectlons. The coefflolent of skew was extremely variable, and no oonslstency was obtained.

(h) Thes1s completed in 1942.

CIL FLOW LOSS THROUGH STANDARD PIPE FITTINGS.

(b) Laboratory projeot.

(c) R. A. Wobor11.

(e) Experimental laboratory study as thesis for B.8. degree in C1yil Englnoering.

(1) To atudy the 108 of head w1th oll flow through otandard plpe flttings of 1,2 , and 3-1noh nominal diameter.

(g) No. 3 fuel o1l was run through $90^{\circ}$ and $45^{\circ}$ elbows and Tees connected end to side and end to end. Plpe friction losses were subtracted from total losees including fittings to determine the net loss due to the fittings. Losses were expressed in terms of $\mathbb{B}$ times velocity head. Values of $\mathbb{B}$ were plotted against veloo1ty Irom 2 to 12 fps and Reynolds number from 2,000 to 6,000 . The value of $K$ vas found to be 1ndependent of veloolty and Reynolds number, but varied w1th $81 z e$ and type of ilting.

(h) Thesis completed in 1943.

HYDROLOGIC INVESTIGATIONS OF AIR MASB MAPB.

(b) Laboratory projeot. (c) A. H. Glenn, R. W. W1lke, G. A. W1lliams.

(e) Thes1s study for B.S. degree in C1v1I Eng1neering.

(P) To correlate published Information on U. S. Heather Bureau da1ly mapo with rainfall data from Cl1matological Data and Da1ly and Hourly Precipitation Hydrolog1c Network, Upper M1881881pp1 Distriot.

(g) A comparison of the fronts accompanying storms and the suocessive hourly positions of the Iine of maximum intensity of rainfall showed definite time and shape correlation between the two. Typical warm front and oold front atorms were studied and the data prosented in diagrammatic form. Attempto to correlate mathematically the ohange in absolute bumidity in the a1r mass and the prec1pitation caused by $1 \mathrm{t}$ were not $\nabla \theta x y$ successful because the meteorologlc data at hand were not sufficlently oomplete for thls type of analy 81 .

(h) Thes18 by Glenn completed in 1942. Theses by W1ke and W1Il1amo oompleted in 1943. 
(1) The material in the se two theses was summariged and examples given in a paper, "Comparison of alr-mas maps with preolpitation-records", published in Trans. American Geophysical Union, 1944. Un1versity of Wisconsin Engineering Experiment Station reprint No. 121 is avallable.

MODEL TESTS OF DU BAY SPILLWAY APRON DESIGN.

(b) Engineering Experiment 8tation project in cooperation with Consolidated Water Power and Paper Company, H18consin Rap1ds, W18.

(c) A. T. Lenz.

(e) Experimental projeot for determination of design of apron structure for Du Bay Dam.

(1) To determine an economical way to dissipate energy of discharge whlch was cutting a granite rock foundation downstream from the splilway.

(g) Twenty-one apron designs were tested to determine an economioal means of preventing erosion below the splilway. The problem was complicated by tho fact that the splilway buckets ended at different levele and the rook downatream from the dam was very irregular in cross-section. From the model studies, a construction program was dovised to prevent exoessive scour whilo bullding the apron at levels to conform with existing rock surface conditions.

(b) Report completed in 1944.

(1) The apron has been partially completed as designed and is punotioning as intended.

\section{ESTIMATION OF STREAM FLON FROM ALKALINITY DETERMINATIONB.}

(b) The Governor's Committee investigating odor nulsance oocurring in the MadiBon Lake B.

(c) A. T. Lenz and C. N. Sayyer.

(e) Experimental method of determining stream flow.

(1) To provide a method of determining stream flow on small atreams tributery to the Madison Lakes in locations where conventional methods were of littio value.

(g) By correlating stream flow measurements made on the average of onoe a week with alkalinity measurements made at the same time, a method was devised for determining the quantltative proportions of hard spring water and solt surface water. From this relation the plows were estimated from alkalinity samples taken once or twice each day.

(b) Project completed in 1944.

(1) "Estimation of stream flow prom alkalinity determinations." Arno T. Lenz and Clair N. Sawyer. Trans. Amerioan Geophysical Union, Pt. VI: 1005-1010. 1944. Un1vers1ty of Wisconsin Englneerlng Experiment Station reprint No. 122 is avaliablo.

CHECXING RUNOFF BY USE OF INFLOW AND OUTFLOW VOLUMES.

(b) The Governor's Committee investigating odor nulsanco ocourring in the Madison Lakes.

(o) A. T. Lenz.

(e) A theoretioal analysis of inflow and outplow volumes to determine average stream flow at an intermediate point between measuring stations.

(P) To chock inflow and outflow volumes to Lakes Monona and Waubesa in order to estimate stream llow at Monona outlet.

(8) Flows to Lakes Monone and Waubesa were corrected for inflow Irom measured and unmeasured tributarles, preclpitation on the lakes, additions and reductlons due to springs, changes in storage, eveporation, and sewage treatment plant inflow for monthly perlode throughout one year. The water balanco thus obtained was exceedingly good.

(h) Report completed in 1944.

(1) "Checklng runoff by use of inflow and outplow volumes." Arno T. Lenz. Trans. Amerloan Goophysical Union, Pt. VI: 1011-1013. 1944. University of Wisconsin Engineering Experiment station reprint No. 123 is avaliable. 


\section{DRAWDOWN STUDIES OF WISCONSIN RIVER RESERVOIRS.}

(b) Laboratory projoct.

(c) D. L. Cazier.

(e) Thes18 study for B.8. degree in C1v1l Englneering.

(1) To deternine whether, by revised operation, the evaporation loss from the 21 Hisconeln River Valley reservolre could be reduced.

(g) A study of the reservo1r levels and outflow records of 16 major reservolrs was made and evaporation 1088 s computed for each week during the summer evaporation season. The theoretical volume without this evaporation loss was computed and studies were made to determine whother changes in method of control would reduce surface areas durling certaln seasons when the reservo1rs were not full. It was conoluded that no 1mportant reduction oould bo made in this eraporation 108 .

(h) Thesis completed in 1945.

(1) A brief summary is ava1lable in Wisconsin Valley Hydrolog10 Researoh Project Report No. 1.

\section{DIBCHARGE CAPACITY OF MODEL OF RINGS DAM.}

(b) Laboratory project.

(o) H. L. Bensel and J. A. Larson.

(e) Experimental laboratory study as thesis for B.S. degree in C1vil Engineering.

(1) To determine by model tests the discharge capacity of gates at K1ngs Dam on the W1sconsin River neer Tomahawk, W18.

(g) A 1:30 scale model wa made of the dam section. Discharge coeffiolents for both oriflce and veir flow were determined for gates individually and collectively with and without plow being taken out in proportion to turbine capac1ty.

(b) Project completed in 1945.

(1) A brief summary 18 ava1lable in Wisconsin Valley Hydrologic Researoh Project Report No. 2.

UNIT HYDROGRAPH STUDY OF BIG EAU PLEINE RIVER.

$\begin{array}{ll}\text { (b) Laboratory project. } & \text { (o) I. J. Beck. }\end{array}$

(e) Theols study for M.S. degreo in C1v11 Eng1neering.

(1) To deternine a $81 x$-hour unit hydrograph for the B1g Eau Pleine RIver for use in plood foreositing.

(g) Runolf records for the Big Lau Plelne RIver at atratford, W18, were analyzed and unit hydrographs determined so that est1mates could be made of the rate of inflow to the B1g Eau Ple1ne Regervo1r. D1stribution graphs and mas curves of percent runoff were also computed. A comparison of actual and computed runoff was made for a storm not previously analyzed.

(b) Thesis completed in 1946.

DISCHARGE COEFICIRNTS OF MODEL RECTANGULAR SLUICE GATES.

(b) Laboratory project.

(o) Truan Hua Feng.

(d) Prof. James G. Woodburn, Hydraul10 Laboratory, Un1vere1ty of Wisconsin, Madison, W18.

(e) Experimental leboratory otudy as thesis for degres os M.8. in Civil Engineering.

(f) To study small-scale models of sluice gates in order to determine the relat1onghlp between upstream and downstream water levels, s1ze of gate opening, and discharge.

(g) Slulce gate openings $0.1,0.2$, and 0.3 feet high in Plumes 10 inches and 2 leet wlde were tested under condition of free shooting flow downetream and with the downstream water baoked up against the gate. Coefficients of discharge were computed, based on differenoe in water levels upetream and downstream from the gate. With Pree flow downstream, falrly constant values of discharge coefflcients were found, but, with submerged flow, coefflclents vary with the difference in vater levels and aloo with the helght of headwater. Pltot tube studies were also made of velocity distribution in shooting flow downetream from the gate. 
(b) Thesls completed in January 1946.

(1) Because of the small scale of the models, it is desirable to run additional tests on a larger scale when possible. Standard text books and referenoe works in hydraulics give different methods of computing discharge through slulce gates. Thls study constitutes an inltial step towards experimental analysis to correlate varlous methods which have been proposed.

CONPARATIVE STUDY OF SHAFT OR MORNING OLORY SPILLWAYS.

(b) Laboratory project.

(c) José Tejada-Saenz.

(d) Prof. James G. Woodburn, Hyaraul1c Laboratory, Un1versity of Wisconsin, Madison, W1s.

(e) Experimental laboratory study as thes1s for M.S. degree in C1v1l Englneering.

(f) To oompare discharge characterlstics in three different designs of vertical splilways for hyöroelectric reservolrs.

(g) Models were made using transparent plastlc materlals and were tested under varlous heads. Discharge coefflclents were determined for varlous conditions of operation. Entralnment of $a 1 r$ and 1 ts effect on discharge was studied.

(h) Thes1s completed in January 1946.

FLOW OF AIR IN PIPES.

(b) Independent study.

(o) A. A. Lemke.

(d) Prof. L. F. Van Hagan, Dept. of Clv11 Englneer1ng, Univers1ty of W1scons1n, Madison, W18.

(e) Thesis for degree of C.E.

(1) (1) To introduoe the new alr friction chart, "Flow of alr in plpes", prepared by the author for usage in the design of alr malns for the activated sludge process of sewage treatment; (2) to expound the theory and development of the chart; (3) to compare the results of this chart w1th numerous existing charts and formulae; and (4) to explain the application of this chart to the design of alr malns, particularly malns for supplylng alr to Chloago Pump Company diffuser equipment.

(g) In design of plpe systems for alr flow conslderable discrepancy was found between varlous charts and formulae, especially in the larger and more expensive plpe s1zes. These discrepancles may be due to lack of accurate description of plpe surface, to inadequate information on temperature range, or to non-differentiation between free and compressed alr. Some of the diagrams also are not in convenlent form to use.

Th1s study develops a new chart based on best a vallable technioal information apply1ng to the range of temperatures and pressures desired and supplemented by a table of oorrection factors to make the chart applicable to various types of plpe surfaces and glving the prlotion 1088 in conventent form. The study shows the selection of plpe slzes based on allowable pressure drop rather then on allowable veloclty.

(b) Thesis completed in 1946.

(1) An extens1ve bibllography is given at the end of the thesis.

WORCESTER POLYTECHNIC INSTITUTE, Alden Hydraul1c Laboratory, Woroester, Mass. PITOMETER LOG CAIIBRATION.

(b) P1tometer Log Corporation, 237 Lafayette St., New York, N. Y.

(c) L. C. Neale.

(d) Prof. L. J. Hooper, Woroester Polyteohn10 Inst1tute, Worcester, Mass.

(e) Calibration of the individual pltometer logs only.

(f) Rating of various instruments.

(g) Testing the shlp logs on the olrcular current meter rating station 1 in st1ll water operating from 2 to $28 \mathrm{fps}$.

(h) Completed. (1) These instruments are rated from t1me to t1me. 


\section{SHIP LOG CALIBRATION.}

$\begin{array}{ll}\text { (b) Bendiz Avlation Corp. } & \text { (c) L. C. Nerle. }\end{array}$

(d) Pro1. L. J. Hooper, Worcester Polytechn10 Inst1tute, Woroestor, Mass.

(e) Experimental callbration of instruments.

(g) P1tot and 1mpeller types of 1nstruments were rated and effect of varlous modilications dotermined.

(b) Test completed.

(1) Tested on current meter rating station from 2 to $28 \mathrm{fps}$.

SHIP LOG CALIBRATION.

(b) Brown Instrument Company, Phlladelphia, Pa. (o) L. C. Mealo.

(d) Prop. L. J. Hooper, Worcester Polytechnic Institute, Worcester, Masa.

(e) Experimental calibration of instruments.

(g) P1tot type only and callbration of same. (h) Completed.

(1) Tested on cursent meter rating atation from 2 to $28 \mathrm{fps}$

U. S. DEPT. OF AGRICULTURE, FOREST SERVICE, California Forest and Range Experiment Station, Berkeley, Cal1f.

(1304) MODEL STUDY OF FLOOD AND EROSION CONTROL STRUCTURES FOR MOUNTAIN CHANNELS (FOR LOS ANGELES RIVER FLOOD CONTROL PROJECT OF THE U.S.D.A.).

(b) Forest Serv1ce, Region 5, U. S. Dept. of Agriculture.

(d) Reglonal Forester, Fcrest Serv1ce, San Franc1sco, Cal11.; Prof. M. P. O'Brien, University of Californla, Berkeley, Cal1f.; Director, California Forest and Range Experiment Stat1on, Berkeley, Cal11.

(e) Laboratory project in cooperation with the University of California and in collaboration w1th Cal1fornia Forest and Range Experiment Stat1on.

(1) To supplement and verify hydraulic design computations of barriers, scour, and backwater conditions below the barriers, gradients of impounded material, and the effects of other appurtenant structures and replanting operations.

(g) A barrler planned for construction in the channel of the Arroyo seco was reproduced in model form on a scale of $1: 50$. Sufficient length of channel upstream and downstream of the structures (from 2000 to $6000 \mathrm{ft}$ ) was Included to 1nsure proper approach and backwater conditions.

(b) Project completed.

(1) This study included hydraulic tests of a $1: 50$ scale model of a debris barrier and the contiguous channel. Tests of the barrier included the determination of splllway capacity, the performance of the overflow, the developnent of a stepped overflow orest, and the operation of the barrier with and without detrital material impounded upstream from the barrier. Tests in the channel cover the problem of acour downstream and deposition upstream from the barrier. Initial tests of deposition upstream from the barrier were based on bedioad and rates of transportation as developed in the laboratory. Results of these tests were reasonably verified by data obtalnod from the flrst major storm after completion of the prototype structure.

A discussion of these data was presented before the Waterways Division at the Los Angeles (Celifornia) Meeting of the A.S.C.E. In July 1943.

Results have been reported as follows: Model study of Brown Canjon Debrls Barrier". Karl J. Bernel and Robert L. Sanks. Proc. A.S.C.E., Vol. 72, No. 5: 613-628. May 2946.

U. S. DEPT, OF COMMERCE, NATIONAL BUREAU OF STANDARDS, Washington, D. C.

(b) Federal Public Housing Authority.

(c) J. L. French, E. E. Ferguson, R. S. Wyly. 
(d) Chlef, National Hydraulic Laboratory, Nat1onal Bureau of Standarda, Washington 25, D. C.

(e) Experimental. To furnish information to code-making authorities.

(f) To investigate the effect of fixture discharge, drain diameter and slope, and type of vent fltting on the permissible distance between a flxture trap and 1ts vent, incofar as this length influences the self-aiphonage of the P1xture trap harmfully.

(g) Different constent rates of flow were impressed on various trap and drain combinations, and the resulting reduction in trep seal was observed. Variables in the test set-up were the length, diameter, and slope of drein, size and kind of trap, and type of stack pitting. Continuous waste and vent Instollations were used with long-turn $T-Y$, short-turn $T-Y$, and stralght T stack fittings. The relation between the se variables was determined, and the results were compared with similar tests for typlcal lavatory installations.

(h) The report on this investigation has been completed.

(496) DETERMINATION OF THE DISCHARGE COEFFICIENTS OF FLOW NOZZLES.

(b) Cooperat1ve research sponsored by the A.S.M.E. Speclal Research Committee on Fluld. Meters.

(c) H. S. Bear, F. C. Morey。

(d) Mr. H. S. Bean. National Bureau of Standards, Hashington 25, D. C.

(e) Experimental.

(f) To determine the discharge coefficients of "long radius" Plow nozzles; to Cetermine the most satisfactory location for pressure holes; to check, compare, and correlate Anerican and European designs and practices.

(g) A group of approximately 30 flow nozzles ranging from 2 to 16 inch plpe slzes were tested by ten cooperating laboratories using water, 011, alr, and steam. Not all s1zes were tested by each laboratory, and each used, at most, two of the fluids mentioned. Each nozzle was tested by at least two of the laboratories.

(h) Completed.

(1) "Research on flow nozzles." H. S. Bean. Mech. Eng. 59: 500-502. 1937. "Determining flow nozle contours." 5 . C. Worey. Instruments 10: 157-160. 1937.

"Some results from research on flow nozzles." H. S. Besn and S. R. Beitler. Trans. A.S.M.E. 60: 235-244. 1938.

"Nozzle coefflolents for pree and subierged discharge." R. G. Folsom. Trons. A.S.M.E. 61: 233-238. 1939.

"Discharge coefficlents of long-radius flow nozzles when used with plpe-riall preasure taps." H. S. Bean, S. R. Beltler, and R. E. Sprenkle. Trans. A.S.M.E. 63: 439-445. 1941.

(981) INSTALLATION REQUIREMENTS FOR HEAD METERS.

(b) Cooperative research sponsored by the A.S.M.E. Special Research Commttee on Fluld Meters with the National Bureau of Standards.

(c) H. S. Bean, F. C. Morey.

(d) Mr. H. S. Bean, National Bureals of Standards, Washington 25, D. C.

(e) Experimental.

(f) To determine the effect of piping arrangements preceding an orlpice meter or Plow nozzle upon the indfcations of the meter.

(5) Testg were mado w1th alr, comparing a 4-1nch experimental meter with a 4 -1noh referenoe orlfice meter. The plping preceding the experimental meter could be varled to include different conflgurations of elbows and valves. Tests were also mada with water, determining the rate of flow by direct velghing.

(1) "A review of the installation requirements for head meters." H. S. Bean. Proc. Fourth Annul Appalachian Gas Measurement Short Course. West Virginia UnIversity, Morgantown, W. Va. 1941. 
"Installation requirements for head meters." H. S. Bean. Heating, Plping, and Alr Conditioning 13: $744-746.1941$.

U. S. DEPT. OF THE INTERIOR, BUREAU OF RECLAMATION, Denver, COLO.

Inquirles concerning the following 54 projeots should be addreseed to

The Chlef Englneer, Bureau of Reolamation, Denver, Colo.

GRANBY DAM BPILLMAY.

(b) Bureau of Reclamation.

(c) Hydralic laboratory.

(e) Speciflc design 1nvestigation.

(P) To make a comprehensive study of the splllway for Granby Dam.

(g) A 1:24 soale model of the sp1llway entranoe and channel vas used.

(h) Testing has been completed and the report publ1shed.

ALL-AMERICAN CANAL SYSTEM.

(b) Bureau of Reclamation.

(c) Hydraule laboratory.

(e) Speolfic design investigation.

(1) To determine the bohavior of the channel downstream from the Coschella Canal Wash Overohutes and to revise the overchute designs to correct for any unPavorable conditions.

(B) 1:24 soale model of the canal and wash overchute was used.

(h) Testing has been oompleted and the report published.

MODEL WAVE STUDIES FOR CONTRA-COBTA CANAL.

(b) Bureau of Reclamation.

(o) Hyaraul10 laboratozy.

(e) Spec1p1c design Invertigation.

(P) To develop a practioable method of damping the waves produced by pump operation in the pinlshed canal.

(g) A 1:24 soale model of the canal, the gatos, and the pumping plant transition was used.

(h) Testing has been completed and the report published.

ALTUE DAM SPILLWAY.

(b) Bureau of Roclamation.

(e) Spec111c design 1nvest1gation.

(c) Hyaraulic laboratory.

(1) To deterinine the hydraul1c characteristios of tho struoture and the recommonded apron for the splliway st1lling-pool.

(g) A 1:60 soale model of the central portion of the structure and a $1: 24$ seotlonal model of the splilway were used.

(h) Testing hes been oompleted and the report published.

OUTLET WORKS OF ANDERSON RANCH DAM.

(b) Bureau of Reclamation.

(o) Hydraul1c laboratory.

(e) Speo1110 design 1nvert1gation.

(f) Hydraulic model studies to determine the quantity of als sequirea for tho outlet works of Anderson Ranch Dam.

(g) A model on a soale or 1:12 representing the center outlet chomber was used.

(h) Testing has boen completed and the report publishod.

BIG SANDY NO. 2 SPILLWAY.

(b) Bureau of Reclamation.

(o) Hyaraul10 laboratory.

(o) Spec110 deslgn Investigation. 
(1) Determination of the capacity of the splllway, the weir coefficlenta, the abllity of the crose-welr to etralghten the flow, and the general hydraule behavior.

(g) The model of the eide-channel sp1llway was constructed to a scale of 1:30 and included the et1lling bain, tallwater control gate, and overflow channel.

(h) Testing has been completed and the report published.

DAVIS DAM.

(b) Bureau of Reclamation.

(o) Hydraulic laboratory.

(e) Specific design invest1gation.

(p) To perform the required calibrations, to check adequacy of the proposed designe, and to determine the most eat1efactory method of operating the epillway and outlet gates.

(g) The model of the outlete was on a scale of 1:50, the model of the channel was on a ecale of $1: 100$, and the recomended eplilway bucket propile was evolved from etudies on $1: 100$ and $1: 48$ scale models.

(b) Testing has been completed and the report published.

THE 58-INCH BALANCED. VALVES FOR SHOSHONE DAM.

(b) Bureau of Reclamation.

(c) Hydraul10 laboratory.

(e) Speciflc design investigation.

(f) Determination of an operating sohedule for minimizing damage to needle tips and discharge condu1ts during the 1943 season.

(g) The model of a 58-1nch balanced palve was made on a soale of $1: 8$.

(h) Testing has been completed and the report published.

RECIRCULATION OF CONDENBER COOLING WATER AT ANTIOCH 9TEAM ELECTRIC PLANT.

(b) Bureau of Reclamation.

(c) Hydraul10 lahoratory.

(e) Speciflo design investigation.

(f) To determine the extent of recirculation of condenser cooling water.

(g) A model on a ecale of 1:100 whloh included a small portion of the river adjacent to the steam plant o1te was used.

(h) Testing has been completed and the report published.

FLANGE GASKETS FOR RING-FOLLOWER GATES FOR BOISE STORAGE PROJECT.

(b) Bureau of Reclamation.

(c) Hyaraulic laboratory.

(e) Spec1f10 design investigation.

(1) To design flange gaskets for the 72-inch ring-follower gates of sore material other than rubber because of 1 te scarcity during the war.

(g) A model of the gate and a pump for applying pressure up to 400 pounds per square inch water pressure was used.

(h) Testing has been completed and the report published.

GATE SEAL DESIGNS FOR GRAND COULEE DAM AND SHASTA DAM.

(b) Bureau of Reclamation.

(c) Hydraulic laboratory.

(e) Speoll10 deeign invertigation.

(f) To 1mprove the seal for the Grand Couleo inetallation and to develop a eeal for the gates for the shata Dal diversion tunnel.

(g) Two models were used in these teste, a pisual sectional seal model and a 10-inch ring-8eal model.

(h) Testing has been completed and the report published.

SHABTA POWER PLANT.

(b) Bureau of Reclamation.

(c) Hydraul1c laboratory. 
(e) Spec1rio design Invest1gation.

(1) To develop a eatlsfactory seal for the sphere valves for Shata power plant.

(g) Two bydraul10 models were used in which seal assemblies hav1ng full-size cross-sections could be tested.

(b) Testing ha been completed and the report published.

COASTER GATES.

(b) Bureau of Reclamation.

(c) Hydraul10 laboratory.

(e) Speo1ilc design 1 nveatigation.

(1) To cheok the computed downdraw and to study the effect of the shape of the gate bottom on 1 t 8 magndtude.

(g) Several models wore used on different soales.

(b) Testing has beon completed and the report publiehed.

VAIVES FOR FRIANT DAM.

(b) Bureau of Reolamation.

(o) Hydraulic laboratory.

(o) Spoc1110 dosign Invest1gation.

(1) To develop improved doslgns of needle and tube valves for Friant Dam.

(g) Models of the valves were made on varlous goales.

(h) Teoting has been completed and the report publlshed.

REDESIGN OF OUTLET VAL,VES FOR BHOSHONE DAM.

(b) Bureau of Reclamation.

(c) Hydraulto laboratory.

(e) Spec1p1c design 1nvest1gation.

(P) The redesign of the outlets at Shoshone Dam, to prevent severe damage by oav1tat1on, wa evolved frol aerodynamio and hydraulio studies.

(g) A model of the 58-1nch balanced outlet valves wa constructed on a scalo of $1: 8$ (hydraul10) and $1: 6$ (aerodynamio).

(b) Testing has been completed and the report published.

ROSS DAM SPILLWAYB.

(b) Bureau of Reclamation.

(c) Hydraul1c laboratory.

(e) Speo1fic design investigation.

(1) The hydralilic Investigation was made pertalning to the design of the sp111way 6 to be used in connection with inoreasing the helght of the Ross DaIn.

(8) A model was constructed of the entire arch dam, with top at elevation 1650 to $1: 60$ gcale.

(b) Testing has been completed and the report published.

LOVELOCK DIVERSION DAM.

(b) Bureau of Reclanation.

(c) Hydraul10 Iaboratory.

(o) Speciplc design 1nvest1gation.

(i) To determine the range of tallwater elevations for hydraul10 jumps, and scour that would occur.

(g) Fox these investigations a $1: 16$ seotional model was used.

(h) Teating has been completed and the report published.

MASTEHAY ERTRANCES FOR THE FRIANT-KERN CANAL.

(b) Bureau of Reclamation.

(c) Hydraul10 laboratory.

(e) Spec1l1c design 1nvest1garion.

(f) To obtain data on the relative merlts of two different propoeed wasteway designs.

(g) A 1:16 scale model of a section of canal with the wasteway entrance and gate section was used. 
(h) Testing has been completed and the report published.

MASON CITY CULVERT INTAKE.

(b) Bureau of Reclamation.

(c) Hyaraul1c laboratory.

(e) Speciric design investigation.

(I) To check the orlginal design for 1 te rated alscharge.

(g) A 1:30 scale model of the intake chute, transition, and culvert was used.

(b) Testing has been completed and the report published.

BOULDER DAM.

(b) Bureau of Reclamation.

(c) Hydraul1c laboratory.

(e) Spre1110 des1gn Invertigation.

(1) Study of the backwater effect expected in the Boulder Dam tallrace due to dredging of the river channel downstream and to the proposed suture regulation of Dav1s Dall Reservo1r.

(g) A 1:60 scale hydraul1c model of the outlet structures, sp1llway, and related river channel downotream was used.

(h) Testing has been completed and the report published.

SPILLWAY AND STILLING BASIN FOR CHERRY CREER DAM。

(b) Bureau of Reolamation.

(c) Hyaraul1c laboratory.

(e) Spec1f10 des1gn 1nvest1gat1on.

(i) To verify the hydreulic performance of the deslgned structure.

(g) Studies w1th 1:60 hydraul1c model.

(h) Testing has been completed and the report published.

ALAMOGORDO OUTLET NEEDLE VALVE.

(b) Bureau of Reclamation.

(c) Hydraul1c laboretory.

(e) Spec1f10 des1gn Invest1gat1on.

(1) To Investigate the adequacy of proposed ohanges in the Alamogordo outlet valves to prevent cavitation erosion.

(g) A model having a scale of 1:5, representing a one-elghth sector through the valve and a portion of the outlet condult, using air as a test medium, was employed.

(b) Testing has been completed and the report published.

HOLLOW-JET VALVE FOR ANDERSON RANCH DAM.

(b) Bureau of Reclamation.

(c) Hyäraul1c laboratory.

(e) Speciflc design Investigation.

(1) To Investigate the Peas1b111ty of the proposed design. The Investigation included a study of the valve operating mechanlem, the pressure distribution on critical portions of the valve, a comprehensive calibration of the design, and a determination of a sultable location for the balancing porte in the neodle.

(g) The inlet diameter of the hydraul1c models was 6 inches in all cases.

(h) Testing has been completed and the report published.

HIGH-HEAD MERCURY MANOMETER FOR GREEN MOUNTAIN DAM.

(b) Bureau of Reclamation.

(c) Hyöraulic laboratory.

(e) Specific design 1nvertigation.

(1) To develop a new deglgn for a high-head mercury manometer which would min1mize breakage and be freo of troublesome mercury leaka.

(g) The new manometer was made of a single plece of plastio tube and a plastlc pot.

(h) Testing has been completed and the report published. 
ALVA B. ADAMS TUNNEL INLET STRUCTURE, COLORADO-BIG THOMPSON.

(b) Bureau of Reclamation.

(c) Hydraul1c laboratory.

(e) Specific design investigation.

(1) To determine a design for the control structure which would cause a minimum loss of head at a ressoncble cost and at the same time comply with the requirements of the law authorizing the project.

(g) In the teste a $1: 10$ model of the 20 covered bays and the double side-channel sp1liway having a gate-controlled outlet which was connected to the tunnel portal by a double transition, was used.

(h) Testing has been completed and the report published.

MARSHALL FORD DAM.

(b) Bureau of Reclamation.

(c) Hydraul1c laboratory.

(e) Specific design investigation.

(p) The studies were confined to the ultimate development based on action for the more severe conditions that were expected to exist after completion of the high dam.

(g) The tests were made with four separate models: 1:40.8 sectional model of the inftial crest, $1: 68$ model representing half of the ultimate spillway, l:40.8 sectional model of the ultimate spillway, and $1: 25.5$ model of one river outlet.

(h) Testing has been completed and the report published.

WATER REGULATION AT ANDERSON RANCH DAM.

(b) Bureau of Reclamation.

(c) Hydraul1c laboratory.

(e) Spec1f10 design investigation.

(f) To determine the capaoity and location of the alr vents in the penstook.

(g) A 1:40 hydraulic model of the penstock was used.

(h) Testing has been completed and the report published.

JET PUMP FOR KESHICK DAM FISH TRAP.

(b) Bureau of Reclamation.

(e) Speciflc design Invest1gation.

(I) To determine the adequacy of the original design.

(g) A 1:10 scale model of the plah trap, distribution chamber, mixing tube, and jet pump were used.

(h) Testing has been completed and the report published.

HOWELL-BUNGER VALVE FOR ROSS DAM.

(b) Bureau of Reclamation.

(c) Hydraul1c laboratory.

(e) Speciflc design Investigation.

(1) To determine the operating characteristics relative to the installation of two of these valves at the downstrenm end of the lower outlet conduits at ROBв Dam.

(g) The model consisted of a 6-inch diameter valve.

(h) Testing has been completed and the report published.

MOON LAKE DAM SPILLWAY AND AUTOMATIC GATES.

(b) Bureau of Reclanation.

(o) Hydraul1c Iaboratory.

(e) Speo1fic derign 1nvestigation.

(1) To develop a float-controlled gate that would maintain a constant reservolr water-aurface elevation for all discharges through the gate.

(g) Analytical studies and testr with scale models.

(h) Test1ng has been completed and the report published. 
GLORY-HOLE SPILLWAYS AT OWYHEE DAM.

(b) Bureau of Reclamation.

(c) Hydraulic laboratory.

(e) Specific design invest1gation.

(1) To cheok pressures, discharges, and to ascertain, so far as possible, that no adverse events would oocur in the operation of the prototype.

(g) A 1:48 scale model was used whloh 1ncluded the topography surrounding the splilway, the sp1llway and ring-gate control, and the discharge tunnel below the splilway.

(h) Testlng has been completed and the report published.

SCOFIELD DAM SPILLWAY AND OUTLET WORKS.

(b) Bureau of Reclamation.

(o) Hydraul10 laboratory.

(e) Speciflo design investigation.

(f) The objective of the studies was to check the dealgng of the varlous features of the splliway, such as the entrance, the crest, the chute, and the st1llingpool, to ensure that they would perform their required functions of passing the predioted flood.

(g) The varlous features to be studied nere construoted to a geometrio soale of $1: 30$ in such a way that revisions could bo made quiokly and easily.

(h) Tosting has been completed and the report published.

SHADOW MOUNTAIN DAM SPILLWAY AND OUTLET.

(b) Bureau of Reclamation.

(o) Hydraul10 laboratory.

(e) Specific design investigation.

(f) To verify the adequacy of the spillway design and of the outlet which 18 incorporated within the spillway.

(g) A model was constructed on a scale of 1:30 which included the inlet to the spillway, the splilway, and section of the river channel below the dam.

(h) Testing has been completed and the report published.

FLUID POLARISCOPE.

(b) Bureau of Reclamation.

(c) Hydraul10 laboratory.

(e) Experimental study.

(f) To obtain some method that can be used qualitatively to observe how a moving or a stationary object affects the flow, or quant1tatively to calculate the necessary data.

(g) A two-dimensional model usually conslsts of a thin section of the struoture or device to be tested, approximately 1/2-1nch to 1-1nch thlok, mounted between two plates of glass or clear plastic. A plane polarized lens and a quarter wave plate are put on one slde and a diffused light source on the other.

(h) Testing has been completed and the report published.

CALIBRATING SINGLE ORIFICE GATEB.

(b) Bureais of Reclamation.

(c) Hydraul10 laboratory.

(e) Speciflo design investigation.

(f) It was desired that the discharge in second-feet be obtalned for varlous combinations of openings and submergence of the gate.

(g) The tests were made on a model of a gate with varlous combinations of open1ngs and submergence.

(h) Testing has been completed and the report published.

DAVIS DAM SPILLWAY OVERFALL SECTION.

(b) Bureav of Reclamation.

(c) Hydraulic laboratory.

(e) Specific design investigation.

(f) To Investigate pressures on the splliway face when the profile of the overflow 
section falls inside the trajectory of the sheet of water flowing over 1 t.

(g) The investigation of the pressures on the face of the revised spillway was made by the ald of a model constructed on a $1: 50$ scale.

(h) Testing has been completed and the report published.

FLAP GATES FOR GILA PUMPING PLANT NO. I.

(b) Bureau of Reclamation. (c) Hyoraulic Iaboratory.

(e) Specific design investigation.

(f) To determine a simple and effective remedy for reducing the shock to the structure when the llap gates were closed.

(g) The model consisted of an 8 -inch horizontal propeller pump powered by \& 3 hp motor.

(h) Testing has been completed and the report published.

HIGH-HEAD RADIAL GATES FOR DAVIS DAM OUTLETS.

(b) Bureau of Reolamation.

(c) Hyảraulic laboratory.

(e) Spec1f1c design investigation.

(f) To determine the characteristics of a radial gate operating under a head of 113 feet.

(g) Tests were made on a $1: 30$ scale model of the gate with one slde of the gete seat transparent so the llow of water through the gate could be observed.

(h) Testing has been completed and the report published.

ALL-AMERICAN CANAL CHECK STATION 60\%00.

(b) Bureau of Reclamation.

(c) Hyaraulic laboratory.

(e) Specific design investigation.

(1) The determination of the most economical siructure that would serve the roquirements and provide ample protection against downstream orosion.

(g) A seven-gate structure set level wits the canal botton and without transitions was constructed on a $1: 30$ cale.

(h) Testing has been completed and the report published.

ELEPHANT BUTTE DAM SPILLWAY ALTERATIONS.

(b) Bureau of Reclamation.

(c) Hyaraul 1c laboratory.

(e) Spec1fic design investigation.

(i) To show the action of the splilway at Iarge discharges and to detarmino neom osary alterations to make 1 t sape.

(g) A model of the splilway was used, which included a anall portion of topography upstream from the splliway as well as the splilway orest sectlon. transition channel, and chute. The model was on a seale of $1: 40$.

(4) Testing has been completed and the report published.

FRESNO DAM SPILLWAY AND OUTLETS.

(b) Bureau of Reclamation.

(c) Hyäraulic laboratory.

(e) Spreiplo design investigation.

( $P$ ) To study the proposed designs of the eplilway and outlet works, to assure safe and economical operation of these structured.

(g) The 1:60 scale model that was used inclvded the complete sp111way, outlet works, reservolr, and downstream rolver ohannel.

(h) Testing has been completed and the report published.

RIVER CHANNEL CONDITIONS BELOW BRIDGE CANYON DAM.

(b) Bureau of Reclamation.

(c) Hyảraulic laboratory.

(e) Spoc1pio design Inveatigation.

(1) To prevent the undermining of the downstream portal struotures of the 
ap1llways and outlet tunnels when they are in operation.

(g) The 1:60 scale model that was used included the complete sp1llways, the seven outlet condults, the powerplant tallrace, and a 2000 -foot reach of the river.

(h) Testing has been completed and the report published.

GRAND COULEE PURIPING PLANT AUTOMATIC FLOATING RADIAL GATES.

(b) Bureau of Reclamation.

(c) Hydraulic laboratory.

(e) Spec1e1c design investigation.

(1) To 1llustrate on a qualitative basis only, the manner in whlch the gate 18 operated.

(g) The gate model used had a radius of 24 inches, was 12 inches wide, welghed 22 pounds, was approximately 20 inches high, and was hinged 19.5 inches above the gate 8111 .

(h) Testing has been completed and the report publibhed.

FLOW CHARACTERISTICS, DISCHARGE, AND PRESSURES RELATIVE TO SUBMERGED DAMS.

(b) Bureau of Reclamation.

(c) Hydraulic laboratory.

(e) Generel experimental study.

(1) These tests deal ent1rely with submerged flow over small dams. They includo investigation of the various types of flow enoountered, determination of discharge coefflcients, and the measurement of water surfaces and pressures on the dam and in the stilling basin.

(g) Two sets of experiments were performed using two different models.

(h) Testing has been completed and the report published.

PILOT KNOB WASTEWAY.

(b) Bureau of Reclamation.

(c) Hydraul1c laboratory.

(e) Specific design 1nvestigation.

(P) To develop smooth entrance conditions at the right-angle entrance from the main canal to the wasteway channel.

(g) The tests were conducted on a $1: 36$ wasteway model and a $1: 12$ model of a single bypass.

(b) Testing has been completed and the report published.

GILA GRAVITY MIAIN CAHAL WASH OVERCHUTES AND WASTEWAYS.

(b) Bureau of Reclamation.

(c) Hydraulic laboratory.

(e) Specifio design investigation.

(f) To study flow conditions in the inlet transition, overchute section over the main canal, the stilling basin, in the overchute inlet, section over the main canal, wasteway inlots, and the stlling basin for separate and concurrent operation of the wasteway and overchute.

(g) Two models were used for the tests. The flrst on a scale of 1:18 did not include the wasteway. The second on a scale of 1:24 included the wash overchutes and masterays.

(h) Testing has been completed and the report published.

AIR INJECTION INTO THE FLOW IH THE BOULDER DAM SPILLWAY TUNNELS.

(b) Bureau of Reclamation.

(c) Hyaraulic laboratory.

(e) Spec1lic design 1nvest1gation.

(1) To determine the effect of air infections into the spillway flow as a shock absorber between the high-veloclty water and the tunnel IIning, and secondly to determine effect of air ingections on sub-atmospheric pressures along tho surface of the tunnel invert.

(g) A model of the Arlzona splllway tunnel on a scale of 1:60 was used.

(h) Testing has been completed and the report published. 
BHASTA DAM COASTER GATE AND HANDLING EQUIPMENT.
(b) Bureau of Reclamation.
(c) Hyaraul10 laboratory.
(e) Specific design investigation.
(f) To check the computed downpuli on gate design for a now shape for the gate bottom.
(g) A 1:17 scale model of the condult and ooaster gate was used for the studes.
(h) Testing has been completed and the report published.

CALIFORNIA WASTEWAY REPAIRS.
(b) Bureau of Reclamation.
(c) Hydraul1c laboratory.
(e) Specif1o design investigation.
(s) To change the orlginal design to prevent further erosion of the left alde of the channel downatream from the stilling pool.
(B) A I:30 soale model of the wasteway and check structures and a seotion of the canal upstream from the wasteway gates was used.
(b) Testing has boen completed and the report published.

ESTES PARK POWER PLANT BUTTERFLY VALVES.
(b) Bureau of Reclamation.
(o) Hydraul10 laboratory.
(e) Spec1f10 design invertigation.
(f) To determine the characterlatics of the valve in operation.
(g) The different butterfly valve leaves were tested with alr as the fluld medium.
(b) Testing has been completed and the report published.

ANGOSTURA DAM SPILZWAY.

(b) Bureau of Reclamation.

(o) Hydraul1c laboratory.

(e) specifto design investigation.

(f) To check the adequacy of the proposed splllway for Angostura Dam for releasIng water during floods.

(g) Two models were used: one, a sectional model, was placed in a long Ilume; the other consisted of the complete splliway and downstream river channel.

(h) Teating has been completed and the report published.

CANYON FERRY DAM BPILLWAY AND RIVER OUTLETS.

(b) Bureau of Reclamation.

(c) Hydraulic laboratory.

(e) Speoiflc deaign investigation.

(f) To study the proposed design of the splliway and outlet works, and to make necessary changes to assure safe and economlcal operation of these structures.

(g) A 1:60 model of the overflow section, river outlets, gates, and st1ling pool was used.

(h) Testing has been completed and the report published.

STARTING AND STOPPING PUMPS FOR GRANBY DAM PUNPING PLANT.

(b) Bureau of Reclamation.

(c) Hydraul1c laboratory.

(e) Speciflc design investigation.

(f) To study the feasiblilty of starting the pumps whlle throtting the flow in the intake lines, to obviate the necessity for purchase of valves for the discharge lines.

(g) An g-inch vertical pump with a tank reservo1r to supply water to the pump was used.

(h) Testing has been completed and the report published.

SACRAMENTO SAN JOAQUIN DELTA, CENTRAL VALLEY, CALIFORNIA.

(b) Bureau of Reclamation.

(c) Hydraul1c laboratory. 
(e) Theoretical and experimental study for project planning and design.

(f) To establish the effects on ocean salinity intrusion of transferring water through the delta channels Prom the Sacramento River to the San Joaquin river.

(g) A higinj distorted scale made with a vertical exaggeration of 1:48, adjusted to glve the proper tidal flow, was used to study the mechanics of salinity intrusion. Fle ld studies established that no density current existed and that only true physical diffusion was involved. Solutions of a special blue dye were used to represent salinity and determinations of concentration were made accurately and quickly with a spectrophotometer.

(h) Studies sompleted.

(1) Report of work covered in Hydraul1c Laboratory Reports Nos. 142 and 155.

U. S. DEPT. OF THE INTERIOR, BUREAU OF RECLAIIATION, EI Paso, Texas. SILT BURVEYS OF ELEPHANT BUTTE RESERVOIR.

"S1lting of reservolrs." Technical Bullet1n 524, U. S. Dept. of Agriculture. Investigations me made perlodically and results published when completed.

QUALITY OF WATER STUDY ALONG THE RIO GRANDE.

"Quality of water studies" in the annual bulletin of the International Boundary and Water Commission, El Paso, Texas.

Invest1gations are made perlodically and results published when completed.

U. S. NAVY DEPT., DAVID TAYLOR MODEL BASIN, Washington 7, D. C. CHARACTERISTICS OF A BOAT-TYPE, LOAD-CARRYING BUOY.

$\begin{array}{ll}\text { (b) Naval Research Laboratory. } & \text { (c) P. Elsenberg. }\end{array}$

(d) The Director, David Taylor Model Basin, Washington 7, D. C.

(e) Experimental investigations for design purposes.

(f) To develop methods of characterlang a moored load-carrying buoy for fast currents and outline methods of determining mooring line sizes.

(g) Model Basin tests were conducted w1th models of the NRL Mark 3 Boat-Type buoy under varlous conditions of loading. Loads were applied by a carefully calbrated depressor. Cr1terla for overload and stability were developed. Graphical methods were developed for determin1ng mooring ine sizes.

(h) Completed and report issued.

(1) Characterist1cs of the NRL Mark 3 Boat-Tyoe Buoy and determination of mooring I1ne s1zeв." P. E1senberg. TMB Report 550. September 1945.

THE PANAMA CANAL hydRAULlC LABURATURY, Dlablo He1ghts, Canal Zone.

HYDRAULIC ROUGHNESS COEFFICIENTS FOR LARGE CHANNELS.

(b) Special Eng1neer1ng D1v181on, Dept. of Operation and Ma1ntenanoe, The Panama Canal.

(c) Hydraulic Section personnel under superviaion of J. S. Meyers.

(d) The Supervising Englneer, Special Eng1neering Division, Diablo He1ghts, Canal Zone.

(e) Project is to provide design information for use in Isthmian Canal studies. 1947. These stud1es were authorized by Publ1c Law 280, 79 th Congress, to investigate means for inoreasing the securlty and capacity of the Panama Canal. 
(P) To soen ava1lable data on hydraulio roughness of largo channels, and to seloot values for use in dosign of an enlargod canal.

(g) Inquirle were directed to TVA, USBR, and USED, asking for data on largo channels. Replies were recelved clting observations on the Tennesser, Colow rado, M1881881pp1. Colurab1a, and other large rivers, and for some dredged channels. Observat1ous were made of roughness of the ex1sting canal ohannel In Galliard Cut.

(b) Completed.

(1) Hydraul10 roughness coef11010nts for large channols." Isthmian Canal stud16日 Memorandum 106, approved December 9, 1946.

(1013) MANIFOLD RESTARCH.

Mool manifold experiments." Edward Soucek and E. W. Zelniok. Proc. A.9.C.E. Ootober 1944.

(1200) CONTROL OF SURGES IN CANAL.

"Surges in Paname Canal reproduced in model." F. W. Edwards and Edward Soucek. Proc. A. S.C.E. January 1944.

(1311) FORCES FOR OPERATING MITER GATES.

"Hydraul10 model 1nvest1gation of mlter gate operat1on." N. H. Ambter. Proo. A. B.C.E. March 1944.

\section{(1201) (1202) (1203) (1204)}

Each of these projects is oompletely covered by 1ndividual reports, and signilscant results Irom all profects are comblned in the report, "Lock model tosto Design 3\%, by J.C. Erench and M. J. Webster, August 1942. All reports are in unpublished form (mimeographed, typed, eto.) and a few coples of each are avallablo for loan.

\section{(1201) LOWER APPROACHES TO LOCKS.}

"Report on hydraul10 model studies for the lower approsches to the third looks". J. M. Groves. Auguet 1941 .

In conneotion with the design of the Third Locks of the Panama Canal, tests were conducted on a hydralle model of the lower approaches to the Th1rd Locks for the purpose of studying navigation conditions in the lower approaches caused by sp1111ng and by density currents when lock gates separating Presh and salt water are opened.

A 1:60 scale model representing the area of the lock chamber, the width of the look at the approach, and the downstrear ohannel, was construoted. Varlous types of outlets and varlous lengths and degrees of plare of arched and solld approach walls vere tested under both steady flow conditions and under conditione simulating actual splling operations. Velocity distribution in the approaches was determined. Llquids of diperent density wore used for studying density ourrents.

It was conoluded Prom the tests that symmetrical approaches w1th walls plared not more than 6 degrees on each slde of the center I1ne are most desirablo (solld approach walls of equel length and symetrically flared at 4 degroos with the oenter line of channel wore adopted). Floor outlets disoharging between the approach walls or other types of outlets discharging behlnd the approach walls were satisiactory. Upturned outlets and side-port outlets diecharging between the approach walls were unsatisiactory, particularly for one-culvert operation.

\section{(1202) MODEL OF EXIBTING LOCK.}

"Hydraul1c model study of existing locks.". E. W. Zeln1ok. June 1942.

Presented in thls report are results of testo conducted on $1: 25$ scalo model of the weat chamber of the existing Pedro Miguel Locks. Forces acting on a veseol and other phonomena occurring during a lockage were determined lor varlous operating conditions. Fll11ng curves obtained from the ex1stIng prototype locks are in close agreement with similar model data. A comparison of the results of this study with the results of tests conducted on a model of the Third Locks, Design 1 , shows that for the same p1lling 
t1me the latter gave much smaller forces on the vessel. By opening one leaf of the culvert valve first and then lmmediately starting the other leaf, the forces on the model vessel were reduced substantially with only a small increase in the fllling time.

\section{(1203) MODEL OF PROPOSED LOCK.}

"Report on lock hydraulic system - Des1gn 1." J. C. French. April 1942.

Presented in this report are results of tests conducted on a $1: 25$ scale model of a floor-filling hydraulic system for the Third Locks. The forces on a vessel during a lockage were determined for varlous opening characteristics of the culvert valves. Tests indicated that excessive longitudinal forces could be eliminated without serlously affecting the filling or emptying time, by increasing the valve period. Under all conditions, lateral distribution of flow in the lock chamber was satisfactory and produced negligible transverse forces. The wall culvert $81 \mathrm{ze}$ could not be reduced without causing a substantial increase in the longitudinal force for a comparable plling time. The system contained slightly more lateral area than necessary for the wall culvert olze used. Speclal tests to determine the effect of the magnitude of the motion of the vessel were conducted on another floor-filling system identifled as Design 2. The results indicated that the longltudinal forces on the vessel were independent of the moduli of the system within the test limits.

"Report on lock hydraulic system - Design 2." C. Y. Hitchcock, Jr. April 1942.

Presented in this report are results obtalned from tests on a $1: 25$ scale model of a floor-flling hydrauilc system for the Th1rd Locks. Forces on a model vessel and pilling times during lockage operations were determined w1th varlous opening characteristics of the culvert valves for comparison with similar tests on Design 1. Tests indicated that an increase in the number of ports and lateral culverts did not affect substantially the forces on the vessel or the flling time, if the total area of ports and laterals remain unchanged. Excessive longitudinal forces could bo eliminated, without serlously affecting the filling tine, by increasing the valve period. Under all conditions, lateral distribution of flow in the lock chamber was atisfactory and produced negligible transverse forces.

"Lock model tests - Design 3." J. C. French and M. J. Nebster. August 1942. Presented in this report are the results of tests conducted on a $1: 25$ scale model lock of the Third Locks Project. The final design of the bottomfllling hydraulic system was tested to determine flllirg and emptying times, mooring forces, pressures in the system, and culvert valve operation. The tests are compared to those conducted on two preliminary models of the same type of system, and to tests of a model of the existing Panama Canal Locks. Results show that the Third Locks hydraulic system is highly sat1sfactory. Mooring forces on a loaded ore ship are much less than in the existing locks.

(1204) MODEL OF LOCK CULVERT VALVES.

"Hydraulic model investigation of lock culvert valves." T. E. Murphy. January 1942.

Presented in this report are data from tests conducted on $1: 20$ scale hydrau11c models of two types of radial lock valves, seotcr and tainter. Both types of valves were tested in tension and in comoression. Observations on these models, together with observations on the general lock models, ind1cated that the tainter valve in tension is most suitable for the Third Locks. Tests also demonstrated that a thin lower lip on the valve was superior to a circular lip. The thin lip reduced the tendency for hydraulic porces to vibrate the valve and decreased the lifting force required to open the valve.

(1204) MODEL OF LOCK INTAKE.

"Hydraulic model investigation of lock culvert intakes." T. E. Murphy. May 1942. This report presents data from tests of hydraulic models of intakes for the Third Locks culverts. A 1:20 bcale model incorporating a portion of the forebay, the intake structure, the upstream valve section, and a short reach of the tunnel was bullt. Hydraulic characteristios of proposed designs were studied. A satisfactory manifold intake with four ports was developed from the tests. 
U. S. WAR DEPT., CORPS OF ENGINEERS, LOS ANGELES DISTRICT HYDRAULIC LABORATORY, Los Angele B 14, Cal1f.

(1333) HYDRAULIC MODEL STUDY, SPILLVAY AND OUTLET WORKS FOR SANTA FE FLOOD CONTROL DAM, SAN GABRIEL RIVER, CALIFORNIA.

March 1942. Loan copy may bo obtained from U. S. Waterways Experiment Stat1on, V1cksburg, M188.

(1332) HYDRAULIC MODEL STUDY, LOS ANGELES RIVER CHANNEL IMPROVKMENT, DAYTON AVE. TO FOURTH ST., LOS ANGELES, CALIFORNIA.

December 1943.

HYDRAULIC MODEL STUDY, SPILLWAY FOR SA"INAS DAM, SALINAS RIVER, CALIFORNIA.

June 1944. Loan copy may be obtained from U. S. Waterwaya Experiment station, V1cksburg, M18s.

HYDRAULIC MODEL STUDY, INTAKE AND BYPASS STRUCTURES, LYTLE AND CAJON CREEKS CHANNEI IMPROVEMENT, SANTA ANA RIVER BASIN, CALIFORNIA.

July 1946. Loan copy may be obtained from U. S. Waterways Experiment station, V1cksburg, M188.

U. 8. WAR DEPT., CORPS OF ENGINEERS, PORTLAND DISTRICT, PortIand, OTO. (Bonneville Hydraul10 Laboratory).

Inquiries concerning the following four projects should be addressed to The District Engineer, 628 P1ttook Blook, Portland 5, ore.

CONCRETE ABRABION STUDY, BONNEVILLE SPILLWAY DAM, BONNEVILLE, OREGON,

(b) War Dept., Corps of Englneers, Portland D1striot, Portland ore.

(c) R. B. Cochrane, Head, Hydraul1c Design Sect1on, Portland District.

(e) Experimental research.

(f) To determine abrasive effect of sllt-laden water on varlous concrete mixes as part of program inltiated to determine cause of erosion on baffles and deok of Bonneville Spillway Dam.

(g) The concrete blocks made of varying concrete mixes were subjected to s1ltladen jet $1000 \mathrm{ppm}$ for perlods up to 10 days. Angle of attack and velocity of jet were varied. Abrasion determined by survey of eroded area.

(b) Study completed and Bonnev1lle Hydraul10 Laboratory Report No. 15-1 1 s sued.

SILT SAMPLING STUDY, BONNEVILLE SPILLWAY DAM, BONNLVILLE, OREGON

(b) War Dept, Corps of Englneers, Portland D1strict, Portland, Ore.

(c) R. B. Coohrane, Head, Hydraul1c Design Section, Portland D1strict.

(e) Experimental research.

(1) To determine amount and charecter of suspended materlal passing over Bonneville Dam as part of program inltiated to determine cause of erosion on baffles and deck of Bonneville sp1liway Dam.

(g) Suspended load data from samples taken once or twice a week by a speo1al sampling pipe from jet 1 saulng beneath gate of Bonneville Dam. Fineness determinations, $X-r a y$, and petrographic exam1nation of suspended material made by U. S. National Bureau of Standards.

(h) Study completed and Bonnev1lle Hydraul10 Laboratory Report No. 14-1 188 ed on January 15, 1944.

MODEL STUDY OF 23-FT OUTLET TUNNEL FOR MUD MOUNTAIN DAM, WASHINGTON.

(b) War Dept, Corps of Engineers, Seattle D18trict, Seattle, Wash.

(c) R. B. Cochrane, Head, Hydraul1c Design Sect1on, Portland D1strict.

(e) Experimental, design. 
(1) To Investigate hydraulic design of 23-1t diameter regulating tunnel for Mud Mountain Dam.

(g) A 1:25 soale model of tunnel intake tower, 23-ft diameter tunnel, 8.5- ft diameter penetock, and Howell Bunger regulating valves vere used to determine pressure grade lines and general plow data. Safe reservoir operating levelo were asoertalned so 28 to avold strong vortex action in tunnel intake and bore aotion in 23-it diameter tunnel.

(h) Model study completed and Bonnev11le Hydraul10 Laboratory Report No. 6-1 18sued on July 15, 1942.

(1106) MODEI STUDY OF THE NAVIGATION CHANNEL CONDITION ON THE COLUMBIA RIVER AT BONNEVILLE, OREGON.

(b) War Dept., Corps of Englneers, Portiand District, Portland, Ore.

(o) R. B. Cochrane, Head, Hydraul1c Des1gn Section, Portland D1strict.

(o) Experimental, design.

(f) To determine the most sat1afaotory plan for the elimination of undesirable ourrent conditions at the entrance to the downstream approach channel of the Bonnevilie Nav1gation Look.

(g) A concrete flxed bed type of model construeted to a $1: 200$ scale horlzontally and 1:100 scale verticaliy was constructed of the 5-m1le reach of the Columb1a R1ver downstream from Bonnev1lie Dam. Flows from 40,000 of s to $1,000,000$ ofs were slmulated and especial attention given to the effects of realigning the river banks, enlarging the powerhouse talireoe, and deepening the look approaoh ohannel.

(b) All testing has been completed, and Bonneville Hydraul10 Leboratory Report No. 2-1 was 1 ssued on January 30,1942 .

U. 8. WAR DEPT., CORPS OF ENGINEERS, ST. PAUL DISTRICT, 8t. PQUI 1, MInn.

Information relative to the following seven Hydraul10 Laboratory Reports may be obtalned from the District Engineer, Corps of Englneers, st. Paul 1, Minn.

(1035) PROTOTYPE LOCK AYDRAULICS TESTS TO VERIFY MODEL EXPERIMENTS.

Hydraul10 Laboratory Report No. 46. October 1941.

MISSIBSIPPI RIVER, NAVIGATION CONDITIONS IN UPSTREAM APPROACH TO LOCK NO. 10, GUTTENBERG, IOWA.

Hydraul10 Laboratory Report No. 47. Dscember 1943.

ST. KARYS RIVER, FILLING AND EMPTYING SYSTEM FOR THE MRCARTHUR LOCK, SAULT STE. MARIE, MICHIGAN.

Hydraul10 Laboratory Report No. 48. February 1944.

(861) MIBSISSIPPI RIVER, FILLING AND EMPTYING SYSTEM FOR NEW LOCK NO. 2, HASTINGS, MINN.

Hydraul10 Laboratory Report No. 49. Fobruary 1944.

(1037) MISSISSIPPI RIVER, NAVIGATION CONDITIONS IN UPSTREAM APPROACH TO LOCK NO. 6, TREMPEALEAU, WIBCONSIN.

Hydraul1c Laboratory Report No. 50. December 1944.

(860) MISSIS8IPPI RIVER, A BUBMERGIBLE TAINTER LOCK GATE FOR ST. ANTHONY FALLS LOWER LOCK, HINNEAPOLIS, MINNESOTA.

Hydraul10 Laboratory Report No. 51. August 1945.

(109) LABORATORY TESTS ON MODELB OF LOCK HYDRAULIC SYSTEMS.

Hydraul1c Laboratory Report No. 52. June 1946. 
U. S. WAR DEPT., CORPS OF ENGINEERS, U. S. WATERWAYS EXPERIMENT STATION, V1oksburg, M1s8.

Inquirles concerning the following twenty-three projects should be addressed to

The Director, U. S. Weterways Experiment Station, P. O. Box 631, Vicksburg, M1ss.

MODEL STUDY OF SPILLWAY AND STILLING BASIN, ALLATOONA DAM, ETOWAH RIVER, GEORGIA.

(b) The Distriet Englneer, U. S. Englneer offlce, Mobile, Ala.

(o) Personnel of the U. S. Waterways Experiment station.

(e) Experimental, for design of spillway and stilling basin.

(f) To analyze the hydraulic oharacteristies of the spillway and stilling basin, and to develop means of oorreoting any uneoonomic, unsafe, or otherwise undesirable conditions which may exist in the proposed design.

(g) Allatoona Reservo1r, to be located on the Etowah River about 48 m1les upstream from the c1ty of Rome, Georgla, w1ll provide flood control in the Alabama-Coose River system. Provisions will also be made por the generetion of power. The dam will be a concrete-gravity structure. Flow regulation w1ll be afforded by manipulation of 11 gates and by operation of the turbines. The splllway 18 designed to pass a flow of 297,000 ofs under a head of 33.8 peet. The 1:50-8cale model reproduoed about 600 seet of approach channel, the dam proper, the splllway, the powerhouse, and about 4000 feet of the exit channel.

(h) Study completed. Final report: Tech. Memo. No. 214-1, Model study of sp111way, Allatoone Dam, Etowah River, Georgla", Qvallable on loan.

MODEU STUDY OF SPILLWAY AND STILLING BASIN, BERLIN DAM, MAHONING RIVER, OHIO.

(b) The District Englneer, U. S. Englneer OPfice, P1ttaburgh, Pa.

(c) Personnel of the U. S. Watemays Experiment station.

(e) Experimental, for design.

(f) To develop an economical stilling-basin design.

(g) Berlin Dam, to be located on the Mahoning River 18 miles west of Youngstown, Ohio, will provide flood control and low-kater regulation in the Mahoning River valley. The dam will consist essentially of a concrete-gravity sp1Ilway seotion, designed to discharge 79,000 cls, planked by an earth embankment section. The central portion of the spillway; with orest elevation at 1014, w111 be controlled by four tainter orest gates 30 feet long by 18 feet high. The remalnder of the splllway will be uncontrolled and will oonsist of twelve 30-ft bays with crest at elevation 1032. Normal flow will be regulated by three 36-1nch diameter condults through the splliway section. The 1:48-scale model reproduced 720 ft of approach ohannel, the splllway, and $1300 \mathrm{ft}$ of the exit channel. The topographlc features of the approach area and the splllway were moldod of cement mortar. The exit area downstream from the splliway had a movable bed of sand to permit qualitative study of erosion under varlous operating schedules. The sand bed was oapped with a oement crust for stability during velooity observations.

(b) Study completed. Final report: Tech. Memo. No. 193-1, Model study of sp1IIway for the Berlin Dam, Mahoning River, Oh10", avallable on loan.

MODEL STUDY OF POWER PENSTOCKS, BLUESTONE DAM, NEW RIVER, WEST VIRGINIA.

(b) The Distriot Engineer, U. S. Engineer offlce, Huntington, West Virginia.

(o) Personnel of the U. S. Waterways Experiment station.

(e) Experimental, for checking the design of power penstooks.

(1) To determine the degree to which any turbulence oreated by the intake and penstock design may be oarried into the scroll oase and thus affect the performance of the turbines. Evaluation of the probable effect of turbulence In the Bluestone Dam penstocks will be based on comparative data from a model of the penstocks of Norris Dam whloh are known to funotion satisfaotorily.

(g) Bluestone Dam, on New River near Hinton, Weat Virginia, will be a floodcontrol and hydroelectric power project. The dem 18 to be provided with six penstooks for connection to the powerhouse turbines. It 18 proposed to install two 30,000-kw units at the present time, with provisions for 
eventual 1netallation of four additional unitg of the same size. The penstooks leading to the turbine soroll oase of each unlt will be is it in diameter and about $95 \mathrm{ft}$ in langth. The present design incorporates one 63-it radius vertical bend in the penstooks proper. Two models were involved in this study: (I) a 1:36-8cale model reproducing the trash bars, the intake, penstook, and scroll case of one of the power units for the Bluestone Dam, and (2) a 1:36-8cale model of the same elements for one of the power units for Norr1s Dam. Practioally all of the struotures were construoted of transparent pyralin for observation of flow conditions.

(h) Study completed. Final report: Tech. Memo. No. 220-1, Model study of power penstooks, Bluestone Dan, New River, West Virglnia", avallable on loan.

MODEL STUDY OF SLUICE OUTLET, BLUESTONE DAM, NEW RIVER, WEST VIRGINIA。

(b) The D1strict Engineer, U. S. Engineer off1ce, Huntington, West V1rgin1a.

(c) Personnel of the U. S. Waterways Experiment station.

(e) Experimental, for sluice outlet design.

(f) To develop a satiefaotory sluice outlet portal with the deflector inside the face of the splliway.

(8) Located on New River near Hinton, West Virginia, the Bluestone projeot 18 one of the flood-control reservoirs for the Oh10 R1ver Valley. The dam 18 designed as a stralght conorete gravity struoture with an overall length of $2060 \mathrm{ft}$, consisting of $790 \mathrm{ft}$ of splilway section, $310 \mathrm{ft}$ of intake struoture for future power Installation, and 960 it of nonoverflow and abutment sectlons. Flow over the splllway will be controlled by 21 gates each $31 \mathrm{ft}$ hlgh and $30 \mathrm{ft}$ wide. Flood-control outlets cons1st of elxteen 5.67-It by 10-1t rectangular sluiees through the base of the sp1llway. A 1:15-8cale model reproduced a complete eluice, a portion of the downstream faos of the spillway, and the stilling basin.

(h) Study completed. Final Report: Tech. Memo. No. 2-227, Model study of elu10e outlet for Bluestone Dam, Now River, West V1rginla", ava1lablo on loan.

(1337) MODEL STUDIES OF SPILLWAY AND BUCKET, CENTER HIIL DAM, CANEY FORK RIVER, TENNESSFE.

(b) The D1strict Englneer, U. S. Eng1neer 0f11ce, Nashv1110, Tenn.

(o) Personnel of the U.S. Waterway Experiment station.

(e) Experimental, for design of spillway and buoket.

(f) To analyze the hydraul1c characterlet1ce of the sp1llway and buoket, and to develop means of correcting any unoconomic, unsale, or otherwise undesirable conditions which may exist in the proposed design.

(g) Center H1ll Reservo1r, to be located on the Caney gork RIver, 1s a unit of the flood-control plan for the Ohlo and M1881881pp1 RIver valleys. Prov1810ns w11 also be made for the generation of power. Flow regulation w1Il be afforded by $81 \pi$ 6-ft by 4 ft reotangular elu100s through the sp1llway. E1ght 37-ft by 50-pt tainter gates surmounting the sp111way w111 be used to control extreme floods. The splliway 18 designed to pass a flow of 457,000 of under a head of $43 \mathrm{ft}$. Two models wero involved in this study: (a) a 1:40-scale section model of a central bay of the spillway with two adjacent half bays inoluding the buoket and portions of the approach and exit ohannels; and (b) a 1:100-80ale comprehensive model of the ent1re problem area.

(h) studies oompleted. Final report: Teoh. Memo. No. 202-1, Model studies of sp1llway and buoket, Conter H11l Dam, Caney Pork River, Tennesseol, ava11able on loan.

(1239) MODII STUDY OF SPILLWAY AND INTEGRAL SLUICES, CANTON DAM, NORTH CANADIAN RIVER, OKLAHOMA.

(b) The Distriot Englneor, U. S. Engineer office, Tulsa, Okla.

(c) Personnel of the U. S. Waterways Experiment station.

(e) Experimental, for design. 
(p) (a) To analyze the hydraul1c charaoter1st1cs of the Canton Sp1llway, the integral sluices, and the splliway approach and exit channels, as deslgned; (b) to test certain proposed alterations in the design of these elements; and (o) to obtain the best flow conditions possible for the most economical and desirable design that con be developed.

(g) Canton Reservolr, to be located on the North Canadian River near Canton, Okla., vill provide Plood control in the North Canadian and Arkansas River valleys. A chute-type spllivay adjacent to the right abutment of the earthp1ll dam 18 deslgned to pass 342,000 ofs under a head of 29 st and w1ll be surmounted by sixteen 40-pt-nide by 25-st-h1gh tainter gates to control extreme floods. Normal flow regulation w11l be afforded by three 12- 1 t by 7 - ft condults through the center portion of the spillway. Three models were involved in th1s study: (1) A $1: 24-80 a l e$ section model reproduced two interlor bays of the splilway. without slu10es or talnter gates, and 450 ft of the approach channel. (2) A $1: 27-90 a l e$ section model of two interior bays of the splilway included a short portion of the approach and exit channels, one sluice, two orest gates, and a section of the stilling basin. The center crest-gate pler, through which the slu1ce passea, and the slulce were molded of transparent pyralin. (3) A 1:100-soale comprehensive model of a portion of the dam, incorporating changes in design indicated by the first two studies, was used for a general investigation of the control structures of the dam.

(h) Study completed. Final report: Tech. Memo, No. 190-1, Model study of the aplilway and integral sluices for the Canton Dam, North Canadian River, Oklahoma", avallable on loan.

MODEL STUDY OF REGULATING SLUICES, DALE HOLLOW DAM, OBEY RIVER, TENAESBEE.

(b) The District Engineer, U. S. Englneer office, Nashville, Tenn.

(c) Personnel of the U. S. Waterways Experiment Station.

(e) Experimental, for design.

(e) (a) To analyze the hydraul10 characteristics of the slulces whioh have a sharp downward bend, and (b) to determine whether these bends w1ll give rise to cavitation on the bottom and sides of the slulces.

(g) Dale Hollow Reservo1r, to be located on the Obey RIver, 18 a unit of the Plood-control plan for the Ohlo and Mls81s81pp1 R1ver valleys. Provisions w11l also be made for the generation of power. Flow regulation will be afforded by pour 6-pt by 4-pt rectangular sluices through the splilway. s1x 60-pt by 12-pt tainter gates surmounting the sp1llway w1ll be used to control extreme ploods. The splllway 1s deslgned to pass a plow of 159,000 cfs under a head of $24 \mathrm{ft}$. The cupacity of the four slu1ces will be about 6200 ofs w1th reservolr at sp1llway crest. A 1:I5-8cale model was constructed of one palr of llood-control slulces, and reproduced a short section of the approach channel, the sluices and slulce gates, and a portion of the splliway face and bucket downstream from the slulces.

(b) study completed. Final report: Teoh. Memo. No. 197-1, Model study of regulat1ng slulces for Dale Hollow Dam, Obey River, Tennessee", ava1lable on loan.

MODEI STUDY OF STILLING BASIN, DELAWARE DAM, OLENTANGY RIVER, OHIO.

(b) The D1striot Englneer, U. S. Englneer off1ce, C1nolnnat1, Oh1o.

(c) Personnel of the U.S. Waterways Experiment Station.

(e) Experimental, for design.

( 1 ) To examine the hydraul1c performance of the st1lling basin of the Delaware Dam as designed.

(g) The Delaware Dam, to be constructed on the Olentangy fiver, about 6 m1les above the olty of Delaware and about 164 m1les above the Seloto R1ver at Portsmouth, Oh10, w1ll provide flood protection in the scloto River basin and 18 part of the comprehensive plan for the control of floods on the ohlo RIver. The dam w1ll cons1st of a grav1ty-concrete sp1liway section w1th grav1ty-conorete nonoverflow abutment sectlons flanked by rolled-f1ll embankments terminating in low dikes on the abutments. The splilvay, designed to discharge $96,000 \mathrm{cps}$ under a hoad of $28 \mathrm{ft}$, w1ll contain 81x crest gates, each 32 pt long by 25 ft high. Normal flow will be regulated by condults 
through the spillway section. An existing 1:60 undistorted-scale model of the Conemgugh Dam was used for the tests. The helght of the Delaware Dam was made to agree with the Conemaugh model by assuming a model-scale rat10 of 1:31. Accordingly, the detalls of the Delaware st1ling basin were reproduced on a $1: 31-8 c a l e$ and installed at the toe of the Conemaugh overflow seotion.

(h) Study completed. Final report: Tech. Memo. No. 205-1, "Model study of st1ling basin, Delaware Dam, Olentangy River, Ohlo", avallable on loan.

(1336) MODEL STUDY OF SPILLWAY AND STILLING BASIN, DEWEY DAM, JOHNS CREEK, KENTUCKY.

(b) The District Engineer, U. S. Engineer offlce, Huntington, West V1rginia.

(c) Personnel of the U. S. Waterways Experiment Station.

(e) Experimental, for design.

(1) (a) To determine the protective messures necessary to insure the safety of the dam and appurtenant structures; and (b) to investigate and design an efficlent splilway that w1ll pass the design discharge satisfactorily through the splllway and otilling-basin area.

(g) Dewey Reservolr, to be located on Johns Creek, 5.4 m1les above 1 ts confluence w1th Levisa Fork of Big Sandy River, will be used to reduce llood helghts in the Big Sandy and Ohio River valleys. The rolled-p1ll earth dam will have an uncontrolled chute-type splliway deslgned to discharge 22,000 cfs under a head of 25 ft. Normal flows will be regulated by outlet works (maximum capac1ty 5000 cfs) cons1sting of a three-gated intake structure, a 500-ft horseshoe-shaped conduit, and a stllling basin. The 1:50-scale model reproduced 1400 ft of approech channel, the dam proper, the sp11lway, the outlet works, and $1000 \mathrm{ft}$ of the exit channel. The topographlc features of the approach area, the dam, and the splllway were molded of cement mortar. The outlet structures were reproduced schematlcally of cement mortar, wood, and sheet metal. The ex1t area downstream from the dam had a movable bed of sand to permit qualitative study of erosion under various operating sohedules. The sand bed was capped with a cement crust for stabllity during velocity observations.

(h) Study completed. Finel report: Tech. Memo. No. 191-1, Hodel study of ap1llway for Dewey Dam, Johns Creek, Kentucky", avallable on loan.

(1225) NODEL STUDY OF SPILLWAY AND EXIT CHANNEL, EXPERIMENT STATION DAM, DURDEN CREEK, MISSISSIPPI.

(b) The President, Mississipp1 River Comm1ssion, V1cksburg, Miss.

(c) Personnel of the U. S. Waterways Experiment station.

(e) Experimental, for information.

(e) To verify computed flow lines through the existing channel and to determine beneflts to be galned by varlous proposed improvements; also to obtain data for use in connection w1th the hydrological survey of the Experiment Station lake drainage area (see Project No. 224, p. 76, "Hydrological Research Project, Experiment Station Lake Watershed").

(g) The Experiment Station lake dam 18 an earth embankment 450 pt long by 20 ft hlgh. Normal flow from the lake is controlled by a 7-ft dlameter condult through the dam having a maximum capacity of 550 cfs. Flood flows pass over a chute-type sp1llway (crest length $120 \mathrm{ft}$ ). The profect provides for increasing the capacity of the splilway and lmproving that reach of Durden Creek (the common exit channel for both splliway and conduit) which passes through the Station grounds in order to eliminate the danger of damages from flash floods. The 1:25-scale model includes $240 \mathrm{ft}$ of the approach to the splilway, the splilway, the stiling basin, condult exit, and 890 it of the exit channel. The model was molded of concrete and had the proper surface roughness. However, provisions were made for installing a movablebed section below the spillway to study the effects of erosion.

(h) Study completed. Letter report, "Proposed Improvements of the Durden Creek channel at the U. 3. Haterways Experiment Station", JuIy 11, 1944, ava1lable on loan. 
FIELD PRESSURE MEASUREMENTS, FORT PECK POWER PLANT PENSTOCKS, FORT PECK, MONTANA.

(b) The District Engineer, U. S. Eng1neer Office, Fort Peck, Mont.

(c) Personnel of the U. 8. Waterways Experiment station.

(e) Experimental, for infornation.

(1) To determine the amplitude of pressure waves caused by different rates of closure of the penstook gates so that a pressure equal to that of 300 ft of water w11l not be exceeded.

(8) The present 1netallation at Fort Peck Dam cons1sts of one 35,000-kw unit Installed in penstook 1. Ultimately there will be an installed capacity of 105,000-kw cons1st1ng of three 35,000-kw units. The apparatus oons1sted of 11ve Experiment Station hydrostatic pressure colls w1th a range of 0 to 150 p81. These cells were installed in short 4-inoh plpe nipples which were welded into the walls of the power tunnel. The cells were connected to a suitable amplifier and osclilograph for recording pressures. The ampilfler, whlch was developed at the Experiment Station, contalned four ohannels 80 that the pressures from four cells could be taken simultaneougly. Eaoh channel contained a decade reslatance which was used to callbrate the cello before each test was made. The cells were conneoted through th1s amplipler to four supersens1tive elements of a Westinghouse-type PA 0so11lograph.

(h) study completed. F1nal report: Tech. Memo. No. 206-1, Fiela pressure measurements, Fort Peck Powerhouse Penstock, Fort Peck, Montana", avallable on loan.

MODEL STUDY OF STILLING BASIN, NARROWS DAM, LITTLE MISSOURI RIVER, ARKANSAS.

(b) The President, Missis8ipp1 River Comm1ssion, Vicksburg, M188.

(c) Personnel of the U. S. Waterways Experiment Station.

(e) Experimental, for design.

(1) To examine the hydraulic performance of the st1ling basin as designed and to investigate the existence of caritation pressures on bafle piers in the ot1li1ng basin.

(g) Narrows Dam, to be located on the Little M1ssourl A1ver, a tributary of the Ouachita River, approximately 11.4 m1les upstream Prom Murfreesboro in P1ke County, Ark., w1ll be a dual-purpose plood-control and hydroelectric power dam. The dam w11l consist of a concrete-gravity atructure containing a centrally located uncontrolled overflow splllway section (designed to discharge $41,000 \mathrm{cls}$ ), powerhouse intake, and adjecent nonoverflow sections. Normal flow 111 be regulated by two 8.5-1t diameter condults. In order to study the performance of the Narrows Dam stilling basin a quiokly and eff101ently as possible, an exlsting 1:24-scale seotion model of the Conemaugh Dam was ut1lizod for the teats of the Narrows Dam st1111ng basin. The 100.5-1t arop Irom crest to basin of the Coremaugh Dam on a 1:24-8calo model was equivalent to the 173 -ft drop from orest to basin of the Narrows Dar on 1:41.4-80218. Accordingly, the deta1ls of the Narrows Dam at1lilng basin were reproduced on a $1: 41.4$ scale and Installed et the toe of tho Conomaugh overplow sect1on; no attempt to alter the crest shape was mado. The model bagin wiath of the Conemaugh Dam was equivalent to a $124-p t$ section of the Narrows Dam.

(h) Study completed. Flnal report: Tech. Memo. No. 209-1, Model study of ot1lilng basin, Narrows Dam, Little Missour1 River, Arkansas", avallable on loan.

MODEL STUDY OF POWER PENSTOCKS, NORFOLK DAM, NORTY FORK RIVER, ARKANSAS.

(b) The D18trict Engineer, U. S. Englneer off1ce, I1ttle Rook, Arr.

(o) Personnel of the U. S. Waterways Experiment station.

(e) Experimental, for design.

(1) Io determine the degree to which any turbulenoe oreated by the Intake and penstook design may be carried into the soroll case and thus affect the performance of the turbinea. Evaluation of the probable effect of turbulenoe In the Norporle Dam penstocks w11.1 be based on comparat1ve data from a model of the penstocks of Horrls Dam whlch are known to function gatisfaotorily. 
(g) Norfork Dam, on North Fork R1ver about 105 miles north of L1ttle Rook, Ark., w1ll be a flood-control and hydroelectric power project. The dam w1ll have four penstock intake with two complete penatocks installed 1nitially. The powerhouse w1ll be constructed for two 35,000-kw unita w1th only one unit installed at this time. The design of the plant provides for an ultimate capac1ty of four un1ta. Each penstock w111 be 18-pt in diameter and about 164-ft long, and w1ll include a vertical bend with a radus of $75-1 t$. The 1:36-scale model reproduced the trash bars, the intake, penstook, and scroll case of one of the power unlts for the Norfork Dam. Practically all of the structures were constructed of traneparent pyralin for observation of plow conditions.

(b) Study completed. Final report: Tech. Memo. No. 218-1, Model study of Power Penstocka, Norfork Dain, North Fork R1ver, Arkansas", avallable on loan.

MODEL STUDY OF FLOOD PROTECTION PROJECT, PRATTVILLE, ALABAMA.

(b) The Diatrict Englneer, U. S. Englneer offlce, Moblle, Ala.

(c) Personnel of the U. 8. Waterways Experiment Station.

(e) Experimental, for design.

(s) To check computed flow I1nes through the Improved channel downstream from the dam, to determine the discharge capac1ty of the revised ap1llway, and to measure velocities below the splliway and in the channel downetream.

(g) Prattrille, Ala., 18 located on Autauga Creek about 6.5 miles above 1 ts junotion with the Alabama AIver. To control floods at Prattrille, the oxlsting dam $1 \mathrm{~s}$ to be 1mproved by lowering a portion of the orest, thereby 1noreasing the splllway capacisy; a portion of the channel downatream w111 be paved; and conorete retaining wall adjacent to and above the paved sectlon w111 be constructed to prevent the undermining of certain bullaings. The $1: 36-8$ cale model reproduced about 400 it of the approach area, the dam, and about 1200 It of 1mproved channel downetream. A gufilclent amount of overbank area was included in the model to insure correct results.

(h) Study completed. Flnal report: Tech. Memo. No. 200-1, Model study of Hood protection project, Prattrille, Alabama", avallablo on loan.

(1340) MODEL STUDY OF SPILLWAY AND REGULATING SLUICES, WOLF CREEK DAM, CUMBERLAND RIVER, KENTUCKY.

(b) The District Eng1neer, U.S. Englneer 0ff1ce, Nashville, Tenn.

(o) Pereonnel of the U. S. Weterways Experiment station.

(e) Bxporimental, for design.

(f) (a) To analyze the hydraul1c charaoterlst1cs of the Wolf Creek aplliway and sluice outlets; and (b) to develop means of correctlng any uneconomlc, unsale, or otherwlse underirable conditions which may exlat in the proposed design.

(g) Wolf Creek Reservo1r, to be looated on the Cumberland River, 18 a unit of the 1lood-control plan for the Oh10 and M1881881ppl River valleys. Prov1olons w1ll also be made for the generation of power. The dam v111 be 2 comblnod rolled-1111 and concrete-gravity structure. Flow regulation w11I be alforded by $81 \times 6$ it by 4 it slulces through the eplilway section. Ten 37-pt by 50-1t talnter gates surmount1ng the ap1liway w11l be used to cortrol extreme lloods. The splilway 18 designed to pass a flow of 535,000 c ps under a head of $44 \mathrm{ft}$. Three models were involved in this stuay: (a) a 1:40-scale aection model of one central bay of the sp1liway with two adjacant half baya, a portion of the approach ohannel, the bucket, two palra of slulces, and a portion of the exit channel; (b) a 1:15-soale model of one palr of flood-control slulees, which reproduced a short section of the approach channel, the slulcse and slulce gates, and a portion of the spillway face and buoket downstream from the slu10es; and (o) a 1:100-8cale compreiensive model of the entire problem area, which included about 1200It and 2900-It of the channel above and below the dam, respectively, ap1llwas and slu1ces, bucket, power 1ntake, and condults, and about 600-ft of the earth ombankment.

(h) Stuay comploted. Flnal report: Tech. Memo. No. 201-1, MNodel study of sp1liway and regulat1ng alu1oe日 for Holf Creek Dam, Cumberland R1ver, Kentuckg', avallable on loan. 
MODEL STUDY OF SHOALING ELIMINATION IN BASIN OF NAVY DEPARIMENT FLOATING DRY

DOCK YFD-15 AT CHARLESTON, SOUTH CAROLINA

(b) The Chlef, Burequ of Yards and Dooks, U. S. Nary Dept., Washington, D. C.

(c) Personnel of the U.S. Waterways Experiment Station.

(e) Experimental, for general information.

(f) To test the effectiveness of varlous proposed plans for solving the troublesome shoaling problem in the Navy Dopartment's ploating ary dock basin at Charleston, S. C.

(g) An analysis of the results of monthly shoaling surveys in the dry dock basin indlcates that the basin shoals at an average rate of about 3 it per month. Frequent removal of the dry dook and dredging of the basin is therefore necessary to maintain sufficlent operating depth for the dry dock. Such maintenance dredging 18 not only a costly operation, but $1 t$ also requires that the dry dock remain out of operation for a conslderable time for each dredging of the basin. It is belleved that there are two major cause of the rapld shoaling in the basin. The velocities of the silt-laden ebb and flood currents of the river are reduoed by the closely spaced plles of the two plers flanking the basin, with the result that a loss of silt load ocours 28 the flow passes through the pile structures and into the basin. A further loss of veloo1ty, with a corresponding loss of silt load, oocurs within the basin due to the much greater hydraul10 oross-sectlonal area within the basin as compared with the adjacent areas on elther alde of the basin. The model was constructed to an undistorted linear soale rat1o, model-to-prototype, of 1:40. The prototype area reproduced cons1ated of a section of the Cooper River adjacent to the Charleston wateriront 1000 ft in w1dth and extending 1000 ft upstream and 1000 It downstream from the floating dry dook. All plers and other structures along the water front were reproduced to scale in the model. The bed of the model was molded in conorete to the conflguratIons of the prototype survey of 31 March to 18 Apr11 1944. The model was equipped w1th a reversible-flow olrculating system by means of which constant ebb or plood flow could be reproduced. Provisions were made at elther end of the model for the introduction of glisonite, a light-welght shoaling material with a apeciplc gravity of 1.035 whlch was used in simulation of the prototype 811 t.

(b) study completed. Minal report: Tech. Memo. No. 219-1, Model study of shorling elimination in basin of Navy Department floating dry dock YFD-I5 at Charleston, South Carolina", avallable on loan.

(415) MODEL STUDY OF FLOW LINES FOR REVIEW OF MISSISSIPPI RIVER PROJECT.

(b) The President, M1a81881pp1 River Commission, V1cksburg, M188.

(o) Personnel of the U. S. Waterways Experiment Station.

(e) Experimental, for design of flood control project.

(1) To determine flow I1nes along the M1881861pp1 River (between Helena, Ark., and Donaldsonville, La.) for project designed llows on approximate 1939 channel conditions.

(g) Study of flood-control plans for the Lower M1s81ssippl River. The model 1s of the Plxed-bed type with scale ratios: horlzontal dimensions, 1:2000; vertical dimensions, 1:100. Reproduced in the model are the main channel of the M1881881pp1 Rlver Prom Helena, Ark. (300 miles below Ca1ro, Ill.) to Donaldsonv1lle, La. (900 miles below Calro. Ill.); the entire Atchapalaja Basin as far south as the Gulf of Mexico; and the backwater areas of the Arkansas, White, Yazoo, Ouachlta, and Red Rivers.

(h) study completed. Letter report submitted during the conduct of testing.

(1226) MODEL STUDY OF FLOOD-CONTROL PROJECT, MILI OREER, CINCINNATI, OHIO.

(b) The District Englneer, U. S. Engineer offlce, C1noinnat1, Ohlo.

(o) Personnel of the U. S. Haterways Experiment Station.

(e) Experimental, for design.

(f) To study the hydraulic performance of structures proposed for the protection of C1nolnnat1, Ohlo, Prom Ohlo River Ploods.

(g) The Cinolnnati Local Protection Project (Barrier Dam and Un1t 4) 1nvolvee the 
proposed levee and flood wall to be constructed across M1ll Creek to prevent Ohlo Rlver flood waters from backing up into the creek valley, and a barrler dam and pumping atation for the purpose of alsoharging the flood waters of M11l Creek durling high water in the Oh1o River. Two Plxed-bed models were used in the study: (1) A 1:50-80ale model reproduced about 3100 it of M111 Creek (up to the 490-1t contour) from 1 to confluence with the ohio River to a point 100 ft north of Gest street bridge. Although the model was bu1lt of concrete, it was so constructed that alterations could be made to reproduce elther the exlsting channel conditions or conditions with the barrler dam $1 \mathrm{n}$ place. Invest1gations were made for all discharges up to a maximum of 76,000 ofs. (2) A 1:25-8cale model reproduced Mill Creek in the vicinity of the proposed barrler dam and served to determine the flow conditions (veloc1ty d1stributions, existence of edales, etc.) in the pumphouse forebay and exit channel. The model was so construoted that changes in design of the barrier dam and pumphouse could be eas1ly introduced. Invest1gations were made w1th discharges up to 18,000 clo.

(h) Study completed. Final report: Tech. Memo. No. 188-1, "Model study of M111 Creek flood control projeot, Clncinnat1, Oh10", avallable on loan.

MODEL STUDY OF NAVIGATION IMPROVEMENTS, ST. MARYS RIVER, MICHIGAN.

(b) The District Engineer, U. S. Englneer Offlce, Detro1t, Mich.

(c) Personnel of the U. S. Waterways Experiment station.

(e) Experimental, for navigation 1mprovements.

(r) To determine the most sat1sfactory remedial measure to be taken at the inlet to the Mlchlzan Northern Power Company Canal for reducing oross-currents and navigation hazards in the westerly approach to the South Canal.

(g) St. Marys R1ver connects Lake Superior and Lake Huron, and 18 an 1 mportant link in the Great Lakes navigation sjotem. At Bault Ste. Marie, Mich., tho navigation channel by-passes St. Marys Falls through two canal-and-lock systems, the Canadian Canal and the North and South American Canals. Just above the westerly approach to the South Canal, the inlet to the Michigan Northern Power Canal opens into the river and creates cross-currents hazardous to boats whlch have slowed down to enter South Canal. Several means of eliminating this condition are belng investigated. The model is of the plxedbed type with sc8le ratios: horizontal dimensions, 1:150; vertical dimensions, 1:50. Reproduced in the model is a 2-mile reach of the St. Marys River Including portions of the M1chlgan Power Company Canal, the North and South American Canals, the Canadian Canal, the Canadian Power Canal, the U. S. Power Canal, and the regulat1ng works above St. Marys Falls.

(h) Study completed. F1nal report: Tech. Memo. No. 208-1, Model study of plans for 1 mprovement of navigation at the upstream entrance to St. Marya Falls Canal, Mlchigan", avaliable on loan.

(1143) MODEL STUDY FOR IMPROVEMENT OF NAVIGABLE CHANNEL, ABSECON INLET, ATLANTIC CITY, NEW JERSEY.

(b) The District Englneer, U. S. Engliteer offlce, Philadelphia, Pa.

(c) Personnel of the U.S. Waterways Experiment Station.

(e) Experimental, for channel 1mprovements.

(f) To determine the effects of severel proposed jetty locations at the mouth of Absecon Inlet, with especlal attention to their efficacy in maintaining a ship channel and their effect on the beaches at Atlantic City.

(g) Absecon Inlet 18 located between Brigantine Beach on the northeast and Atlant1c C1ty Beach on the southwest, and forms the entrance to the harbor at Atlantic C1ty. The project provides for obtalning and maintalning by dredglng an entrance channel 20 ft deep and 400 ft wide at mlw. It also 18 provided that, should the malntenanoe of the ohannel at any time have a deleterlous effect on Atlant1c C1ty Beach, work upon the 1mprovement can cease, 1t being understood that the interests of the beach are paramount, to those of the inlet. The model was of the movable-bed type. The movablebed reach extended Prom Ventnor, N. J., to a polnt on Brigantine Beach 22,000 ft northeast of Absecon Inlet. Scale rat10 s were: horlzontal dimenslons, 1:500; vertical dimensions, 1:100. Provislons were made for reproducing waves from any drection between south and east, tides of any type, 
and littoral currents elther up or down the beach.

(h) Study completed. Flnal report: Tech. Memo. No. 204-1, Model study of plans for elimination of shoaling in Absecon Inlet, New Jersey", avallatle on loan.

MODEL STUDY OF AGATE BAY HARBOR, MINNESOTA.

(b) The Distriot Engineer, U. S. Engineer opplee, Duluth, Minn.

(c) Personnel of the U. S. Waterways Experiment station.

(e) Experimental, for harbor 1mprovement.

(1) (a) To study wave action within the harbor in order to determine the most advantageous location for new breakwaters to protect the harbor from storm waves; and (b) to determine the eflect of extending eastward the existing dreaged maneuver area within the harbor.

(g) Agate Bay Harbor, located on Lake Super1or, 26 m1les above Duluth, M1nn., 18 an 1mportant 1ron ore sh1pping port. Due to the small s1ze of the harbor, the extended ore docks, and the increased s1ze of the ore vessels, considerable difficulty has been experienced in maneuver1ng vessels within the harbor. In order to provide more maneuver area and to reduce wave action during storms, several plans have been proposed for dredgling a larger area in the harbor and relocating existing breakwaters. The model was of the plxed-bed type constructed to the 11near-scale rat10, model to prototype, of 1:150. Reproduced in the model were the entire harbor, adjacent shore I1nes, all docks in the harbor, the two breakwaters, and the adjoining area of Lake Superior to the 90-ft depth contour. A movable wave machine of the plunger type was used to generate waves of the desired dimensions and from the desired directions. Improved electrical wave-height measuring and recording devices were used to obtaln wave heights at critical points in the model harbor, and a scale replica of a typlcal ore vessel was used to study the elfect of wave action and currents on vessels moored at the ore docks.

(h) Study completed. Flnal report: Tech. Memo. No. 203-1, Model study of Agate Bay Harbor, Minnesota", ava1lable on loan.

(1335) MODEL STUDY OF SALT WATER INTRUSION, LOWER MISSISSIPPI RIVER, LOUISIANA.

(b) The District Englneer, U. S. Englneer 0p11ce, New Orleans, La.

(c) Personnel of the U. B. Waterways Experiment Station.

(e) Experimental, for Information.

(1) (a) To study the action of the salt water wedge; and (b) to Investigate plans for eliminating or delaying this intrusion of salt water from the Gulf of Mexico 1nto the lower reaches of the M18s1ssipp1 River.

(g) The project conslsted of a model atudy of proposed means for stopping or delaying the intrualon of salt water from the Gulf of Mexico into the Lower M1s81s81pp1 River. Th1s intrusion is effected during perlods of low-water Plow in the river, and at times it resulta in contamination of the water supply of New Orleans. The model was of the i1xed-bed type with soale rat10s: length 1:1000; w1dth, 1:350; and depth, 1:100. Reproduced were 40 miles of that reach of the Mississippl River between New Orleans and the Head of Passes. Prov1sion was made for the introduction of fresh water at the upper end of the model (to slmulate any desired prototype hydrograph), and the requisite salt water inflow at the lower end of the model. Potasslum permanganate was mixed with the sal1no solution, thus making $1 \mathrm{t}$ posslble to observe visually the advance of the salt water wedge. The elevations of the wedge interface were determined by the use of an electrical salinity meter which located the position of the interface at points downstream from the head of the wedge.

(h) Study completed. Preliminary report, Model study of salt water Intruelon, Lower MLsissippi River", May 8, 1942. ava1lable on loan.

(1231) MODEL STUDY OF PLANS FOR ELIMINATION OF BHOALING, WILMINGTON HARBOR, CHRISTINA RIVER, DELAWARE.

(b) The District Engineer, U. S. Englneer office, Philadelphia, Pa.

(c) Personnel of the U. 8. Waterways Experiment stat1on.

(e) Experimental, for harbor 1mprovements. 
(P) To develop a plan whlch would eliminate or reduce shoaling in W1lmington Harbor, Del.

(g) W1lmington Harbor extends from the Delaware Rlver to Lobdell Canal in the Chrletina River. The project provides for a channel 400 ft wide by 30 ft deep in the harbor and channels of vary1ng dimensions through the C1ty of W1lmington, Del., and on up the Chrlstina River to Newport, Del, 9 miles above the mouth. Shoaling 18 very rapid in the harbor and 18 attributed to the very low current velocities that prevall. The model 18 of the flxedbed, silt-1njection type w1th scale rat10s: horizontal dimensions, 1:800; vert1oal dimensions, 1:80. Included in the model are the Delaware River from 5 miles above W1lmington to Art1f1clal Island, the Chrlotina River from the mouth to the head of tidewater, and the Brandywine River from 1 to mouth to the head of t1dewater. T1des and currents are reproduced in the model by automat1c tide gates, one at Artificial Island, and the other about 5 miles above Wilmington.

(b) Study completed. Finsl report: Tech. Memo. No. 194-1, Model study of plans for elimination of ghoaling in Hilmington Harbor, Delaware, avallable on loan.

RCOLE POLYTECHNIQUE DE MONTHEAL, Hydraul108 Laboratory, 1430 Rue Balnt-Den1s, Montreal 18, Canada.

MODEL TESTS OF SLUICE-GATE PIERS FOR LES FORGES.

(b) The Shawlnigan Eng1neering Company, Ltd., Montreal.

(c) R. Boucher and assistants.

(d) Prof. Raymond Boucher, Ecole Polytechn1que, 1430 Rue Salnt-Den1s, Montreal 18. Canada.

(0) Experimental research for design purposes.

(f) To determine (1) the discharge coefflcient with free Plow, and (2) the relation between the coefflelent of discharge and the submergence rat1o when drowning effect from tallrace level is produced.

(g) Three model piers (scale 1:78) were secured to the concrete 1loor of the 30-1nch glass-slded plume, representing two full-gate and two half-gate openings. A simple rectangular tall-gate controlied the tallrace water elevation. All depths were referred to the elevation of the floor between the plers. Tests were made f1rst with pree flow to establish the dischargehead relationshlp. In the second serles, a given free llow upstream depth was established and the tall-gate successively adjusted to give different rat1os of downstream depth to upstream depth, Prom whlch was determined tho varlation of the coefficient of discharge in the general formula $Q=O b\left(H+V^{2} / 2 g\right)$ upstream。

(h) Project completed; report submitted to authority.

TESTS ON MODELB OF THE MONTMORENOY FALLS SPILLWAY DAMS.

(b) The Shawinigan Eng1neer1ng Company, Ltd., Montreal.

(c) R. Boucher and assistants.

(d) Prof. Raymond Boucher, Ecole Polytechn1que, 1430 Rue Salnt-Den1e, Montreal 18, Canada.

(e) Experimental project for de日ign information.

(1) To determine flow conditions over two dams in serles, the new one belng placed downstream close to the toe of the old dam.

(g) Models to scale 1:30 of the old and proposed dams were installed close to each other in the 30-1nch glass-81ded plume, the old dam being placed upstream. Tests were made to obtaln the discharge-head ourves for varlous flow conditions over the old and the new dams in serles, namely, old dam complete, old dam w1th 3 feet and 6 feet cut off the top part. Curves of discharge coefflclent versug head were also determined for the new and old dams alone.

(h) Research completed and report submitted to the Shaw1nigan Engineering Company. 
U. S. DEPT. OF THE INTERIOR, BUREAU OF RECLAMATION, Denver, Colo.

The following translations have been prepared by the Bureau of Reclamation. Inquiries should be adressed to the Chief Englneer, U. S. Dept. of the Interlor, Bureau of Reclamation, Denver, Colo.

Rocard, Y.

Les phenomenes d'auto-oscillation dans les installations hydraliques (The phenomena of auto-osclilation in hydraulic Installations). Translated by D.J. Hebert.

Bergeron, M. L. Method graphique generale de calcul des propagations d'ondes planes (General graphical method for calculating the propagation of plane waves). Memo1re de la soclete des Ingeneurs Clv1ls, Vol. LXL: 407-497. July-August 1937. Translated by D. J. Hebert.

U. S. WAR DEPT., CORPS OF ENGINEERS, ST. PAUL DISTRICT, St. Paul 1, M1nn. Craja, A. Graphical analysis of intumescence in channels. La Houlld Blanche. January and March 1946.

U. S. WAR DEPT., CORPS OF ENGINEERS, U. S. WATERWAYS EXPERINIENT STATION, V1oksburg, M18s。

The following translations (except as otherwloe noted) were made by Mr. H. B. Edward8, Englneer Department Research Centers, V1cksburg, M18s. Inquiries should be addressed to The Director, U. S. Waterways Experiment station, P. 0. Box 631, V1cksburg, M1вв.

Aravin, V. I.

Aubert

Bennewitz, D. R.

Bergeron, L.

Cam1chel, M.

Catena, M. M.

Catena, M. M.

Coen-Cagl1, E.

Cornaglia, P.A.
Flow of constant depth in open channels with curvilinear longitudinal bottom profiles. Leningrad Solent. Res. Inst. Hydrotech. Trans. 10(5): 60-68. 1933.

Coefficient d'obstruction (Contraction coefflclent (movable dams)). Cours de Navigation Interieur 2(1): 106-25. 28 pp. 1943-1944. TR.173-46-23.

Estudio de las arenas de la bahia de Corral (Study of the sands in Corral Bay). 11 pp. TR.173-46-25.

Étude des coups de belier dans les conduites, nouvel exposé de la methode graphique (Study of water hammer in pipes; new explanation of the graphical method). La Technique Moderne 28: 33-38. January 15, 1936. 23 pp. TR.173-43-6.

Applications des lols de slmilitude l'étude des phénomènes qui se produlsent $\bar{a}$ l'aval d'un corps lmmergé dans un fluld visqueux en mouvement (Application of the laws of similitude to the study of phenomena produced downstream from a body lmmersed in a moving, v1scous fluid). Parls, 1925. 24 pp.

Canter Cramers, J. Involed van het verschil in soortelifk gewicht van zout en zoet water op stroomling en verplastsing van vaste stoffen in benedenrivieren (Effect of the difference in the speciflo gravity of fresh and salt water upon flow, and upon the transport of sol1d materials in estuaries). De Ingenieur, 1908. $15 \mathrm{pp}$. TR.173-46-14.

Algunas 1deas sobre la inestabilldad de la infraestructura de escollera en los diques de paramento vertical (Some 1deas concerning the instability of the rubble bases of verticalwall breakwater6). Revista de Obras Publ1cas: 60-63.

D1ques de paramento vertical (Harbor breakwaters, Part II, Vertical-wall breakwaters). TR.173-43-49.

L'action des lames de tempete sur les diques marlirmes a parol vertical (Action of storm waves on vertical-wall breakwaters). TR. $173-43-36$.

Du flot de fond dans les liquides (Ground swell, chapters 1 and 2). Annales des Ponts et Chaussées, Vol. 1, 1881. 
E1 sner, Franz

E1sner, Franz

E1sner, Franz

Escande, M. Leopold

Fellen1us W.

Forchheimer, $\mathrm{Ph}$.

Forchhe1mer, $\mathrm{Ph}$.

Franke, $R$.

Glangeaud, L.

Gock1nga, M. R. H.

Hoo, Colonel

Irlbarren Cavanilles, R. Obras de abrigo de los puertos (Protective works 1n

Jaeger, Charles

Jakuschof 1 ,

Joly, G. de.

Jurina, viktor

Kempf, G. and

Hoppe, H. ports). Hev18ta de Obras Publ1cas 89(2709): 13-25. January 1, 1941 .

Ausfluss and ueberfall (DIscharge und overfall). Offene Gerinne, Chap. III, Sec. 8: 384-404. 24 pp. 1932. TR. 173-45-2.

Open channels, Part I, general remarks. Offene Gerlnne. TR. $173-43-8$.

Stehende Wellen; Selches (Standing waves; se1ches). Offene Gerinne, Part III, Sec. 7: 362-383. 22 pp. 1932. TR. $173-44-30$.

Sur le functionnement de l'ajutage cylindrique rentrant (Functioning of a re-entrant, cylindrical discharge pipe). Paper at meet1ng of Academ1e des Sc1ences, March $17,1946$. TH. $173-46-3$.

Văgeros1onsforsỏks Utfóraa à Vattenbyggnadslaborator1et v1d K. Tekn1ska Högskolan (Wave-erosion tests). TR.173= 46.35 .

Excerpts from "Ground water Plow". Hydraul1k, Chap. 3: 67-82, 82-94. 29, 19 pp. February, March 1945. TR. 141$45-9,10$

Elnw1riung des Wassers auf das Flussbett (K1net1c action of stream flow on bed conflguration). Hyaraul1k, 3rd ed.: 527-544, 544-561. 1930. TR.173-43-35,38.

D1e Le1tfäh1gke1ts-Wasserstromessung (D1scharge measurement by the "conduct1v1ty method"). V.D.I. 88: 109. February 1944. TR. 173-44-32.

Phénomènes hyảrođynamlques du ressac, leur rôle dans 10 transport et le trlage des galets (Hydrodynam10 phenomena in connection with the surf). Academie des Science, Séance du 17 January 1941: 146-149. 4 pp. TR.173-45-36.

La pente transversale et son influence sur l'état des rivieres (The transverse slopeand 1 ts influence on river cond1tions). Ann. Ponts et Chaussees 13(1); 112-133. January, February 1931. Translated by G. H. Matthes, M1881881pp1 R1ver Comm1ssion, V1cksburg, M188.

Récherches sur la formation des sinuositlés des cours d'eau (Research concerning the meanderlng of streams). Le Genle C1811 74:212-215, 233-234. March 15 and 22, 1919. $18 \mathrm{pp}$. TR.173-45-13.

Remarques sur quelques ócoulements le long de 11 ts à pente variant graduellement (Some types of flow along beds of gradually varylng slope). Schwe1zerlsche Bauze1tung 114(20): 231-234. November 11, 1939.

The movement of suspended matter in rivers in theory and pract1ce. D18 Wasserw1rtschaft, Vol. 25, No. 5-8, 11. 1932. $25 \mathrm{pp}$. Translated orlginally by W. P. ott and J. C. Van Uchelen of the U. S. Soll Conservation Service. Ealted and partly retranslated by $H . B$. Edwarås, Eng1neer Dept. Research Cienters, V1cksburg, M18. December 1942 .

Les Lames (Waves). Encyclopedia du Gen1e C1v11 et des Travaux Publiques. Travaux Mar1t1mes (v. 15) La Mer et les Cotes, Chap. IV: 55-79. 1923.

Der Donaudurchst1ch bel Wien und selne Geschiebeverháltn1sse (The Danube cutoff at V1enna and 1 ts bed load character1st1cs). Wasserw1rtschaft und Teohn1k 1937: 296-305. No. 31-33.

D1e Erzeugung mass8täbl1cher Meereswellen be1 Modellversuchen (The production of ocean waves to scale in model tests). Werft, Reedere1, Hafen, No. 10: 192-196. 111us. 1929. 
grey, H.

Loper Reyes, Ramon

Natbleu, Roger

Mugge, Hans

Posadas, Carlos

Rutenbeck, T.

Sohs IP, J. B.

Schultzo, E.

Schwarzacher, $W$.

Sta1ger, X.

The18, A.

Thlerry, G. de.

Thorade, $\mathrm{H}$.

Thorade, $\mathrm{H}$.

Thorade, $\mathrm{H}$.

Thorade, H.

Herner, K.

Winke1, R.
Berechnung des Staues 1nPolge voln Querschittseinengungen (Calculation of backweter curve above a contraction in the cross section). Zentralblatt der Bauverwaltung No. 79: 472-475. September 27, 1919.

Veriflcaclon exporimental del diseño hidraulico de los vertedores de la presa "Las V1rgeneg" (Model tests in connection with the design of the Las Virgenes Dam 8p111ways). Irr1gac1ón en Mex1co 24(2): 12-32. March, Apr11 1943. TR. 173-44-29.

Influence de la rugosité des condultes et de leur âge sur le rendement hydraulique (Influence of the roughness and age of plpes upon their hydraul10 output). Ann. des Ponts et Chqusвées 2(10): 331-350. Ootober 1939.

Bau des Bohleusenkanals der staustufe elner Flusskanal1 slerung (Construction of a lock). D1e Bautechn1k 18 $(40-41): 453-475$. September 20, 1940.

El problema de 108 Inundaciones y desagües en la Provincla de Buenos Alres. La soluclón. (Flood and drainage problems in the Province of Buenoo Alres. The solution.) Le Ingenieria 45(10): 1052-1066. 111us. October 1941.

Über Herkstorfarstörung duroh Kav1tation ar Schwinggerät (Destruction of materials by cavitation (Oscillation apparatus)). Ze1tochrlft für Metallkunde 33: 145-152. Apr11 1941. 19 pp. TR.173-43-22.

Het vernietigen van golven door het inspulten van luoht (pneumet1gche solfbsekers) (Breaking up waves by a ir injection (pneumat1c breakwaters)). D1e Ingenieur 55(41): 121-125. October 11, 1940. 11148.

Dle Berechnung der Gerelten in Flussmünungen (Caloulat1on of tides in estuar1es). Die Bquteohnlk 19(12-13): 135-150. March 21, 1941. 11148.

Ein neues Verpabren zur Messung der Schwankungen von Flüssigke1tssplegeln (New method of ineasuring the variations in the gurface elevations of 11quids). Physiks Ze1t8. 44: 216-217. June 1943. 2 pp. TR.173-44-28.

Messen klelner Verschlebungen (Measurement of el1ght displacements). V.D.I. Ztschr. $87(21-22): 332-333$. May 29, 1943.

Dehungsmessung mit ringgebern (Measurement of tension with the "ring indioator"). V.D.I. Ztschr. 87(11-12): 154. March 20, 1943.

Wellenwlrkung an Hafendammen (Action of waves agalnat breakwaterg). V.D.I. Ztschr. $81(26): 743-744$. June 26 , 1937 .

Probleme der Wasservellen, 1931 (Problems of waves in water). Introduct1on, Chap. 1: 1-11. 12 pp. TR. 173-45-11.

Probleme der Wasserwellen, 1931 (Problems of waves in water). General d18cussion, Chap. II: 11-19. $10 \mathrm{pp}$. TR. $173-45-12$.

Probleme der Wasserwellen, 1931. Obozllächenwellen (Problems of waves in mater. Surpaco wave.). Part I, Chap. III: $20-37.28 \mathrm{pp}$. TR. 173-45-16.

Lapacesche und ëhnllohe selohtwassemollen (The Laplace and 81milar formulas for waves in shallow water). Probleme der Wasserwellen: 180-194. 22 p. TR.173-46-18. Wassersplegelberechnung von Kanälen bel gle1chmäss1ger Bewegung und veränderliober Wasserienge (Flow-11ne computation of canals with uniform flok and variable discharge). D1e Bautechnik 19(23): 251. May 30, 1941. Elndelchung und Abrluss (Levees as aspeting plood stages). I) Bautechn1k 19(24): 262-263. Jure 6, 1941 . 
Winke1, R.

Neue Erkenntnisse zum Geschlebeproblem (What has recently been learned conoerning the bed load problem). Der Baulngenleur 23: 211-213. JuIy 20, 1942. $8 \mathrm{pp} .111 \mathrm{~s}$. TR. $173-44-37$.

Hydrology of River Rhine and tributaries. Complled from Dutch and German sources at U. S. Waterways Experiment Station for use of Allied armies. Translat1ons by G. F. Matthes and H. B. Edwards. Varlous paging, maps, and tables.

Illustrated dictionary of large dams. Engl1sh, French, German, 8panish. 1942. 63 pp. Published origlnally as "Dlctlonnalre illustré des Grand Barrages". Francals-Eepagnol, Espagnol-Francals. The sect1ons of German and English were complied by H. B. Edward, Englneer Department Research Centers, V1oksburg, M188. Notes concernant quelques ports du Mexique (Notes concerning some ports of Mex100 , Tamp1co, Salina Cruz, Acupulco, Manzanillo). Annales des Travaux Publ10s de Belgique 1925: 471-475. June 1925. Salinz Cruz, p. 473, translated by

G. H. Matthes. photostat.

\section{COMMITTEES}

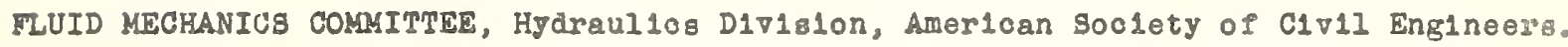

Cha1rman, Dr. Hunter Rouse, state UnIrersity of Iowa, Iowa C1ty, Iowa.

The purpose of the comnlttee is to further the advancement of hydraul 108 through coordination of endeavor with related flelds of fluld mechanics. Inlt1al projeots conslat of the following: (1) Sponsorehip of a four-paper symposium on high-veloolty flow in open channels; (2) 118t1ng of avallable motion plotures of flow phenomena for educational purposes; (3) meking design data ava1lable for new laboratory and demonstration equipnent: and (4) cooperation with proposed organization for publishing abstracts of papers on applied meohanlcs.

COMMITTEE ON HYDRAUIC REBEARCH, Amerlcan Boclety of C1V11 Engineers.

Cha1rmen, Prof. Borls A. Bakhmeterf, 250 West 57 th st., Nen York 19, N. Y.

This commlttee was established in January 1946 for the purpose of developing pundamental research in 01vil engineering on the widest possible basis. Thls is in line with leglslation now pending in Congress to establish a National Research Foundation. The committee bas requested tho cooperation of all hydraul 10 laboratorles and researoh agenc1es in formulating plans to coordinate research and avold duplication. A tentat1ve 11st of what the compltee considers to be fundamental and apeclal research projects has been: prepared, and suggestions and additlong for Impropement of the proposed progran are 1nv1ted. The committee 2.180 desires 1nformation regarding laboratory facllitles and personnel avaliable to conduct research programs along the 11nes suggested. The list of suggested projects and fuli information about th1s program may be obtalned Prom Dr. Baknmeteft at tho above address.

RESEARCH COMITTEES OF THE SECTION OF HYDROLOGY, AMERICAR GEOPHYSICAL UNION, 1530 \& street, N.\%., Washlngton 5, D. C.

Reports of these comittees are published annualiy in the Transactions of the Amertcan Gophysical Union.

BNOW

Mr. Richard C. Farrow, Chalrman,

Water Rlghts Branch,

Parliament Bulldings,

Victoria, B. C., Canada.

GLAOIERS Mr. Francole E. Matthes, Chalrman,

U. S. Geological Survey,

Washington 25, D. C.

PRECIPITATION

Mr. Merrill Bernard, Cha1rman,

U. 8. Weather Bureau,

*ashengton $25, D . C$. 
RUNOFE Mr. R. W. Davenport, Cha1 rman,

U. S. Geologlcal Survey,

Washington 25, D. C.

DYNAMICS OF STREAMS Dr. LOrenz G. Straub, Chalrman,

St. Anthony Falls Hyaraul10 Laboratory,

Kennepin Island, 3 rd Avenue S. . .

M1nneapol18 14, M1nn.

A report of the sub-commlttee on sediment Terminology, under the chalrmanship of Mr. E. W. Lane, reoomending terminology for sediments, w11l soon be pub-

11shed in the Transaotions of the Amerloan Geophysical Union.

EROSION

EVAPORATION AND

TRAN SPIRATION

INFILTRATION

PHYSICS OF

BOIL MOISTURE

UNDERGROUND WATER

PERMEABILITY

CHEMISTRY OF

NATURAL WATERS

HYDROLOGIC REGIONS

LAKES
Dr. W. C. Lowderm1lk, Cha1rman,

Soll Conservation Service,

Washington 25, D. C.

Mr. H. G. W11m, Cha1rman,

Rocky Mounta1n Forest and Range Experiment 8tat1on,

Fort Collins, Colo.

Mr. George W. Muggrave, Chalrman,

Soll Conservation Service,

Washington 25, D. C.

Dr. L. A. Rlohards, Chalrman,

U. S. Reglonal Salinity Laboratory,

P. 0. BOX 672 ,

Rivers1de, Cal1f.

Mr. S. W. Lohman, Chalrman,

U. S. Geolog10al Surves,

351 Equitable Bullalng,

Denver 2, Colo.

Mr. C. E. Jacob, Cha1rman,

U. S. Geological Survey.

Ha shington 25, D. C.

Dr. C. 8. Howard, Chalrman,

U. S. Geological Survey,

Albuquerque, N. Mex.

Mr. Merrill Bernard, Chalrman,

U. 8. Weather Bureau,

Washington 25, D. C.

Dr. Phil E. Church, Chalrman,

University of Washington,

seattle, Wash.

INTERNATIONAL ASSOCIATION FOR HYDRAULIC STRUCTURES RESEARCH

President, Dr. Wolmer Fellen1us, Professor Emeritus at the Teohnioal Un1versity of stockholm, Sweden.

Secretary, Dr. J. Th. Th1j8se, Professor and D1rector of the Hydraullo Laboratory at the Technical University of Delft, Holland.

After belng virtually dormant for over $81 x$ years because of the war, the Assoclation has become reactivated, and plans have been made to hold 1to first post-war meeting in 8tockholm, sweden, in June 1948. The meeting w11 precede a meet1ng of the Congres des Grands Barrages whloh w11l be held In Stockholm the flrst half of June 1948, thus fac1litating the possibllity of part1olpants of the Assoclation meeting to attend the meeting of the Congres des Grands Barrages. Following the latter meeting, arrangements are in progress for excursions in 3weden to varlous dems and hydraulio work.

The last meeting of the Association was scheduled to be held in Liege in Septemiber 1939, but was called off less than a month before the scheduled date because of the break in international relations and the start of the World War. However, the reporte and papers whlch vere to be presented at the meeting were published in full in Stockholm in February 1940 and distributed to the members of the Association.

Applications for new members to the Assoelation are belng accepted. The Assoolation consists of (I) individual members, and (2) corporative members. 
(1) The individual membership may be obtained by anyone who is interested in hydraulic research if he is (a) professor in hydraulics or in a cognate branch of tultion at a technical university, at a university, or at another similar college; (b) director or smployee w1th a leading sltuation at a hydraulic laboratory; (c) member of a leading sclentiflc or technioal assoclation.

(2) The corporative membership is open for (a) institutions for hydraulc works or cognate ranges at a technical university, at a university, or at an equivalent college; (b) hydraulic laboratorles; (o) national committees or analogical comittees of the World Power Conferences, of the Congres des Grands Barrages, and of the Permanent International Assoclation of Navlgation Congresses; (d) public institutions which project, execute, and supervige hydraulic works.

The American Member of the Permanent Committee 1s Dr. Lorenz G. Straub, Director of the St. Anthony Falls Hydraulic Laboratory, University of Minnesota. Persons wishing to become members of the Assoclation may communicate with him.

\section{LABORATORY NOTES}

UNIVERSITY OF ARKANBAs, Fayettev1lle, Ark.

G. P. Stocker, Dean, College of Englneering.

The College does not have enough teachers at the present time to do laboratory research of any kind. It 18 hoped that researoh can be resumed in the near future.

POLYTECHNIC INSTITUTE OF BROOKLYN, BrookIyn, N. Y.

Chilton A. Wright, Professor of Hydraulics and Sanltary Engineering.

At present, activities are largely conflned to student thesis work and olass instruction.

EYRON JACKSON COMPANY, P.O. Box 2017 Terminal Annex, Los Angeles 54, Cal11.

D. H. Cooper, Chlep Test Eng1neer.

During the past two years this company has been engaged in the design and construction of a new testing laboratory, the completion of which will inltiate an accelerated program of research on centrifugal pumps and related products. The new laboratory will occupy 9000 square feet of floor space and have a reservolr capacity of 400,000 gallons. It will be equipped with vertical and horlzontal General Electric DC dynamometer,, 10 to $400 \mathrm{hp}$, 1500 to $4500 \mathrm{rpm}$. These incorporate selsyn speed-monitoring controls. Cal1 brated electric motors extend the range of power avallable to 3000 hp and the speed range down to $360 \mathrm{rpm}$. Ventur1s cover a range from $20 \mathrm{gpm}$ to $50,000 \mathrm{gpm}$. Smeller sizes machined from 18-8 stalnless steel forgings to extremely close tolerances incorporate new features belleved to result in greater accuracy in flow measurement. Facllities are included for research and development of axlal flow pumps. There will be oll reservolr capacity of 10,000 $\mathrm{gpm}$ for conducting research on the effsct of viscosity on centrifugal pumps. Instrumentation is not entirely complete and much of the deta1l will be developed after the laboratory is in operation.

UNIVERSITY OF CALIFORNIA, Department of Eng1neering, Los Angeles 24, Cal11.

Prof. L. M. K. Boelter.

Since the start of 1nstruction in the Englneering Department at Los Angeles about two years ago, no permanent facllities for hydraulic laboratory work have been constructed. One experimental project in cooperation with the U. S. Forest service (reported uncer current projects) has been carried out with temporary fac1lities.

THE CATHOLIC UNIVERSITY OF AMERICA, Washington, D. C.

John B. Cotter, Asst. Professor of Mechanical Engineering. 
The hydraul10 laboratory has been trensferred to the Department of Mechanloal Englneer1ng. No research work 1 s anticlpated at present because increased enrollment requires tho full time and facllitios of the department.

IHE CLEMSON AGRICULTURAL COLLEGE, GLembon, s. C.

Prof. D. D. Curt18, Head, Department of Meohanios and HydraulicB.

Laboratory has not been active recently except for teaching purposes, but

hopes to resume cooperative work and to ongage in researoh in the near future.

COLORADO A \& M COLLEGE, FOrt COllins, Colo.

Robert L. Lew1s, Head, C1711 Englneering Department.

The name of this institution has been changed from Colorado State Coliege of Agriculture to Colorado A \& College, and the former Department of C1v1l and Irrigation Englneering is now the Department of Civil Engineering. Activities in the field of hydraulios and irrigation are being inoreased.

COLUMBIA UNIVERSITY, NOW YOrK, N. Y.

V1ctor scottron, Asst. Professor of Mechenical Englneering.

Prof. Scottron has recently been designated head of the Worthington Hydraulics Laboratory to succeed Prof. Harry L. Parr, who ret1red 1n July 1946. Major changes in the laboratory are contemplated for the near future, but at present sull attention 18 occupled with meeting student needs.

UNIVERSITY OF FLORIDA, Colloge of Eng1neering, Ga1nesville, Fla.

Howard J. Hansen, Associate Professor of C171l Englneering.

The college is in the process of a large expansion program and at present is in the planning stage for bydraulic and hydrology research projects. It is hoped to have several projects under way by the midale of 1947.

UHIVARITY OF IDAHO, Mosoow, Idaho.

Allen S. Jangsen, Acting Dean, College of Englneering.

The laboratory 18 nev, and 18 now being equipped and staffed.

THE JAMES LETPEL \& COMPANY, EpringP1eld, Oh10.

J. Robert Gropf, President and General Manager.

This company has a turbine testing laboretorg. Work has boen curtalled because of the war, and there are no researoh projects to report at this time.

LOUISIANA STATE UNIVERSITY AND A \& COLLEGE, Un17ersity Stat1on, Baton Rouge 3, La.

Dr. Glen H. Cox, Head, Department of Hydraulic Engineering.

Research work wa discontinued during the war, but it $1 \mathrm{~s}$ hoped that by the coming year some projeots w1ll be unäer way.

UNIVERSITY OF MAINE, OrOno, Maine.

H. D. Watson, Head, Mechanical Englneering Department.

No bydraulie research has been carrled on during the past year because of the presaure of undergraduate olass instruction.

MASSACHURETTS INSTITUTE OF TECHNOLOGY, Dept. of C171I and Sanitary Engineering, Cambridge 39, Masa.

Dr. Arthur T. Ippen, Assoclate Profossor of Hydral10B.

The hydraulics laboratory at M.I.T. was closed all through the war. It was reopened in 1 ts old quarters during the spring of 1946, ma1nly for purposes of instruotion and graduate researoh. The equipment and bullding have been renovated to a considerable extent during 1946, a new machine shop established, and ofl10e space provided.

Dr. A. T. Ippen, Assoclate Professor of Hydraul108, 18 in charge of the laboratory and instruction, alded by Dr. J. W. Dally, Assistant Professor of Hydraulcs, and Assoclate Professor A. T. Glfford. Funds were provided by the adminlatration for a permanent laboratory stalf of one technloal assistant and two mochanios. 
S1noe 1 t has long been reallzed that the housing of the laboratory 18 ent1reIg inadequate, the work of the staps, in addition to teaching dut1es, 18 direoted towards planning for a new laboratory bullaing and construction of nev equipment to be used in the new laboratory. It 1s expected that the plans may be reallzed as soon as construction costs have become stabllizad and the necessary materlals can be secured.

Plans for the new bullding provide for a large lloor space to contaln experimsntal research on hyarodynam 1c problems and model invest1gations, for a short towing tank for work in naval architecture, for a stualent laboratory containing a complete set of demonstration and experimental set-ups. In addit1on, the bullding w1ll house extensive shops, storage and dark room fac1l1t1es, a lecture and a reading room, a large drafting room, and a seriso of gtalf offices.

It 18 expected that several fundamental projeots w1ll be started during 1947 in cooperation with outside agencles and that a number of problems will be attacked experimentally by the staff and graduate studonts. The ond of tho year should see the old laboratory full of actlvity and the new hydrodynamlos laboratory well on $1 \mathrm{t}$ s way to prov1de extens1ve and modern fac1l.1ties for research in most flelds of fluld mechanics.

UNIVERSITY OF MICHIGAN, Dept. of C1V11 Eng1neer1ng, Ann Arbor, Mich.

Prof. C. O. Wisler, Professor of Hyaraule Englneering.

The hydraulie engineering division of the Englneering College has Just been granted funds w1th which to establ1sh a Lake Hydraulics Laboratory, which w1ll be provided with a wave machlne and all equipment neosseary for tho study of waves, wave action, beach eros1on, harbor 1mprovement, and, in general, all lake hydraulics problems. Space has been provided and the equipment 18 now being ordered.

A deseription of the elret project to be undertaken is given under project No. 97, page 34, of this bulletin.

STATE OF NEW JERSEY, D1V1810n of Water Policy and Supply, 28 West state st., Trenton $8, \mathrm{~N} . \mathrm{J}$.

H. T. Critchlow, Chlef Engineer.

The D17181on of Water Pollcy and Supply, Department of Conservation, was oreated last July as a result of the consolidation of var1ous atate organizations and is the successor of the former state Water Policy Commisalon. This D1v1sion exercises state jurlsalotion over the diversion of water for public and potable purposes and over the construction of doms and structures within the natural high-water mark of streams.

NORTHWEBTERN UNIVERSITY, The Technological Inst1tute, Evanston, IIl.

Prof. M. B. Gamet, in oharge of Hydraulic Laboratory.

Expansion of laboratory facllities $1 \mathrm{~s}$ contemplated and as the gradurte student enroliment increases, $1 t$ is expected that the research program, other than that conducted solely by staff members, W1ll become aotive.

THE UNIVERSTY OF OKLAHOMA, NOTman, OKIa.

W. H. Carson, Dean, College of Englneering.

The Unlversity of Oklahoma 18 planning to develop an extensive hydraulica laboratory and 18 looking for qualifled englneering personnel to carry on research and to teaoh subjeots related to fluid meohanics.

OREGON STATE COLLEGE, Corvall1s, Ore.

C. A. Mooimore, Head, Dept. of C1v1l Englneering.

The hydraul1c laboratory has been 1nactive, so far as research is concerned, since the war. There will be several graduate students this year, and $1 t$ 1s hoped that the teaching schedule wlil be somewhat relleved from the rush of students so that researoh oan again be resumed.

THE PELTON WATER WHEEL COMPANY, 19 th and Alabama Streets, Ban Franc18co 10, Cal11. P. B. Dawson, Jr., Section Eng1neer-Dovelopment. 
The hydraul1c laboratory has beon expanded with 1noreased fac1l1t1es which include a 120-1t standplpe with overflow for constant head. Research projeots are primarily for the development and test of new and 1mproved produots.

RENSSELAER POLYTECHNIC INSTITUTE, TrOy, N. Y.

Pro1. Grant $\mathrm{K}$. Palsgrove, Dept. of Meohan1cal and Hydraul10 Eng1neering.

No hydraul1c research has been conducted during the past year, beoquse the laboratorles are undergolng complete overhauling.

THE ROCKY MOUNTAIN HYDRAULIC LABORATORY, Allenepark, Colo.

The Rocky Mounta1n Hydraulic Laboratory was establlahed at AIlenspark, Colo., in the summer of 1946. Thls laboratory 1s expeoted to serve the solence of hydraulics in muoh the same way that the Marine Blologioal Station at Woods Hole, Mass., serves the natural sclences. The Allenspark Laboratory w111 operate only in the sumer, and 1ts primary purpose w11l be to fac1litate researoh work of a fundamental nature in hydraul1os and the related solenoes. Students of hydraul108 are weloome to join in the research and eduoat1onal activities of the laboratory, which are under the direction of a board of truetees headed by Gerard H. Matthee. Personnel of the laboratory w11l Include not only experienoed 1nvest1gators, but also young engineers interested in learning the techniques of hydrauilo research. In addition to the experimental work, it 1 s expected thet leotures w11l be soheduled to take advantage of the presence of well-known authorlt1es. The laboratory is a non-prof1t organization. Expenses w1ll be met by donations, grants for the conduct of researoh, and fees for the use of 1ts facll1t10s.

At the start of the plrst season the prinolpal asset of the organization was 1 ts 20-aore 1 te whlch, though totally unimproved, inoluded a quartermile reach of the North St. Vrain Creek flow1ng more than 25 ofs of ory atalclear water, with a total fall of nearly 80 feet. The laboratory w11l have an avallable head of 60 feet and a discharge of 75 cfs when completed.

At the end of the flrst season, a shop bullding 18 by 40 feet had been erected, with eleeplng quarters for two students. More space w11l be arallable next summer, and there are rental oabins and hotels in nearby Rooky Mountaln Natlonal Park. Every. effort w1ll be made to acoommodate all those who signify their desire to partiolpate in the laboratory's program.

As yet no reporte have been written as a result of the work at the laboratory. A suocessful method of washing local sand deposits to free the sand from heavy tannic aold content has been developed. Some work has been done on the formation of vortices on the upstream edge of boulders in a natural stream and the resulting formation of potholes and plutes. This work 18 belng done by G. H. Matthes and John H. Dawson.

Persons who w18h to part1c1pate in the laboratory's program, or who would lire to use 1 ts fac1lities for researoh on a particular project, should communicate with Prof.R.W. Powe11, The Oh10 State Un1versity, Columbus 10, Oh10; Prop. C. J. Posey, State Un1versity of Iowa, Iowa Clty, Iowa; or Prof. John H. Dabson, Untrersity of Colorado, Boulder, Colo.

STEVEN INSTITUTE OF TECHNOLOGY, Exper1mental Towing Tank, 711 Hudson st., Hoboken, N. J.

Kenneth S. M. Dav1dson, Director.

The Experimental Tow Ing Tank at Stevens Inst1tute of Teohnology has non comploted ten years of act1v1ty. In 1932 and 1933, 1ntermittent experimental work was oarrled out in the stevens swimming pool on models of salling yachts towed Prom a stretohed wire. Construction of a 100-pt tank was completed in 1935, and whlle the bulk of work continued to be on sa11drIven yachts, power-dr1ven hulls began to assume a more prominent place in the Tank's activities, as shown by the fact that in 1938, 33 of the 79 models 1nvest1gated were of power-driven types.

Beoguse of the experlence provided by this work, the Tank was able in 1940 to accept contracts from the Navy Department and the Nat1onal Advisory Commitee for Aeronautics. There was a rapid axpansion of activities due to the war, and Tank No. 2 was bullt in 1942. Since that time, the Tank has carried out soveral hundred distinot projects of varying size, 1nvolving hydrodynamic investigations of shipe, alrcrapt, and other bodies. The 
bulk of these projects was for the Army, Navy, and Offlce of Sclentiflc Research and Development, and was almost exclusively of a classified nature. The projects ranged from basio research on steering and turning of ehips to problems of a purely development nature. Tank No. 3, 300-ft long, 12-ft wide, and 6-ft deep, was completed in 1944. In addition, a rotating arm In Tank No. 2, the 75-1t square maneuver1ng tank, was 1nstalled. Th1s apparatus is the only one of 1 ts kind in this country, and only one other, In Par18, 18 known to ex1st in the world.

At the present time the Tank 18 working on Project No. 721 , so there has been an average of 72 new projects per year fos the ten year per1od. The number of models represented by these projects 18 approximately 750 , s1nce many projects require several modifleations of the basic model.

Results of the work are recorded in about 300 Technlcal Reports, 80 Technical Memoranda, and 30 Techn1cal Notes. Technical Reports present the results of work done on a speciflc project, and generally are not published or made available except with permisilon of the client. A number have been published as reports of the National Advisory Commltteo for Aeronaut1cs or of the Navy Department. Technical Memoranda present discussions or analyses of trende or developments revealed by series of tests or the work of other ostablishments. Unless on a classifled subject, they are avallable to anyone inter. ested. Technical Notes cover any subject which cannot properly be cons1dered material for a Technical Report or Memorandum.

W1th the close of the war, the Tank returned to more normal working conditions. At present it is occupled principally by long range projects. Attention 18 belng given to the establishment of a course in hydrodynamlcs, posilbly for graduate students only and in conjunction with their atudies at stevens Institute of Technology or other nearby colleges and universities.

A comprehensive outline of the scope of the activities of the Tank may be had by referring to "The Experimental Toning Tank Ten Year Report", Stevens Institute of Technology, Hoboken, N. J.

SYRACUSE UNIVEFSITY, Syracuse 10, N. $Y$.

Lou1s Mitchell, Dean, L. C. Smith College of Applied Science.

No research 18 belng carried on in the hydraulic laboratory at the present time, because of increased enrollment and needs of students.

THE UNIVERSITY OF TENNESSEE, Knoxv111e 16, Tenn.

Cec1l S. Camp, Assoclate Professor of Hydraulic and Sanitary Englneer1ng. The hydraul1c laboratory 18 just getting back into 1 ts graduate program and has not yet commenced work on any research projects.

TEXAs A \& M COLLEGE, Engineering Experiment Station, College Station, Tex.

A. Cec1l Wamble, Acting V1ce-Director.

The hyaraulic laboratory 18 now inactive, due to personnel shortages. Research will be resumed when appointment 18 made of someone to head this work.

THE STATE COLLEGE OF WASHINGTON, Pullman, Wash.

Prof. Charleg L. Barker, Associate Professor of Hydraulie Engineering. The state College of Washington has been bullalng a new hydraul1c8 laboratory. Although not yet completed, 1 t 18 being used for undergraduate instruction. In 1 t are performed experiments of flow of o1ls and gases, as well as water. The laboratory pumping capac1ty 18 approximately 1000 gpm. In addition, equipment 18 avallable so that experimental work on high heads up to soo peet can be carried on. Becauge of the construction program, no research has been carried on.

WAYNE UNIVERSITY, Detro1t $1, \mathrm{M} 1 \mathrm{ch}$.

Prof. Dudley Newton, Cha1rman, Department of C1v1l Eng1neer1ng. Wayne Unlversity expecte to have a new englneering bullalng which w1ll 1nclude a worth-while hydraul1c laboretory, within the next two or three years. At present there 18 only make-shift equipment for students to conduct hydraul1c experiments. 
Because of disruption of activities due to the war, the present heary student enrollment, or other ressons, the following laboratorles have no research activities to report at this time:

Univeralty of Alaska, College, Alakka.

Dartmouth College, Thayer School of Englneering, Hanover, N.H.

The George Washington University, Clv11 Englreering Dept., Washington, D. C. Lafayette College, C1v1l Engineering Dept., Easton, Pa.

New York Unlversity, College of Engineering, Univeraity Helghta, N. $Y$. Oklahoma A \& College, D1vision of Englneering, St1livater, Okla.

The University of Rochester, Div1sion of Englneering, Rochester, N. Y. Union College, Schenectady, N. Y.

Yale University, School of Engineering, New Haven, Conn.

U. 9. DEPT. OF AGRICULTURE, SOIL CONSERVATION SERVICE, Washington 25, D. C. Lew1s A. Jones, Chlef, D1vision of Drainage and Water Control.

The Hydrolog1c D1vision, the Sedimentation D17181on, and the Drainage D1v1Blon of the Soll Conservation Service have been combined into the Division of Dralnage and Water Control.

The Spartanburg Outdoor Hydraulic Laboratory was alscont1nued about 1940.

The Irrigation Research Laboratory at Logan, Utah, was completad about a year ago and has boen in operation only a few montba.

U. S. DEFT, OF COMMERCE, NATIONAL BUHEAU OF STANDARDS, Waghington 25, D. C. Herbert N. Eaton, Chlef, Hational Hydraulic Laboratory.

The National Hydraulic Laboratory was shut down early in 1943 because 1 ts facllitles and personnel were needed for the development of an ordnanoe project of high priority for the Armea Services. No research work in hyaraulics was carrled on after that date. The laboratory is now belng reconverted and research and testing are being gradually resumed. Some t1me will be required for complete rehabilitation of the bullding and equipment and 1t w1ll probably be another $81 x$ montha before the laboratory wlli be in full operation.

U. 8. DEPT, OF THE INTERIOR, BUREAU OF RECLAMATION, Denver, Colo.

R. F. Blanks, Chief, Englneering and Geological Control and Research Division. During the past year the Bureau of Reclamation laboratories were moved from the Customhouse to new and larger quarters at the Denver Federal Conter. The hydraul10 laboratory has approximately 70,000 square feet of floor space, exclusive of oplece fac1lit1es, in a converted small-arms manufacturing bullding at the Federal Center. On the same reservation a 60-acre tract has been set aslae for extens17e river-flow hydraul10 laboratory inveatigat1ons. With the expansion of the hydraul1c laboratory into 1 ts new quarters, the auxiliary photographio and eloctronic instrumentation laboratories have been enlarged to keep hydraulic laboratory practice abreast of theory.

It is posible that considerable data will be accumuiated in the pleld on the general subject of model-prototype agreenent in the next year or so, inasmuch as soveral hydraul1c siructures now under construction have been especially equipped for convenient observation of hydraulic phenomena.

TENNESBEE VALLEY AUTHORITY, Norr18, Tenn.

G. H. Hickox, in charge, Hydraulic Laboratory.

Because of the pressure of work, It has not been posilble for this laboratory to 11 t t and describe the many projects whlch have been 1nitlated and completed since the 1 ssuance of the last bulletin, as well as projeots now current. The laboratory $1 \mathrm{~s}$ very active, and $1 \mathrm{t}$ is hoped that a report on 1 ts act1vities w11 be included in the next issue of the bulletin.

U. S. WAR DEPT., CORPS OF ENGINEERS, POrtland, Ore.

The D18trict Englneer, Portland D1strict.

The Bonneville Hydraul1c Leboratory decreased 1ts act1vit1es subsequent to the lasue of our last bulletin (Volume X), and by July 1944 had become altogether 
1nactive. In April 1945 operations were resumed, with special attention being given to the revised spillway of Dorena Dam and the MoNary project. The laboratory functions at Bonneville as a subseotional unit of the Portland District organization.

MoGILL UNIVERSTTY, Montreal, Canada.

Dean R. E. Jamieson, Cha1rman, Dept. of C1vil Englneer1ng.

Because of the large number of gtudent, the resources of the hydraullo laboratory are taxed to capacity for undergraduate teaching. Research 1. carried on by students for master's degree, and some research on a small soale is done for industrial concerns, such as investigations in waterhamer in plpes, tests of hydraulic models including turbine runners, etc.

THE SHAWINIGAN WATER AND POWER COMPANY, P.0. Box 6072, Montreal, Canada.

M. Balls

Experimental hydraulic installation was inactive during the war, and at present no hydraul1c studies are contemplated.

EUROPEAN AND ASIATIC LABORATORIES.

LAABORATOIRE DE CHATOUX, FRANCE.

M. A. Nizery, Chiel Engineer, Ponts et Chaussees, 199 rue de Grenelle, Paris VII, France.

A nev French hydraulic laboratory at Chatoux, about 10 k1lometers Prom Paris, 1s belng planned by the soclety, L'Eleotricite de Franoe, Service National, an organization comprising all of the societieg in France for the production and distribution of electricity. It will have a stalf of about plety persons and will be occupied with problems in the flelds of reducod-scale models of hydraulio structures, river control problems, harbor problems, and problems of general interest.

Through the courtesy of Prof. 1r. J. Th. ThIjsse, Director of the Hydraul1o Lab oratory at the Technical University of Delft, Holland, it has been learned that the following laboratories are now in operation. Th1s 11 st probably is incomplete.

BELGIMM Laboratolre de Recherohes Hydraliques,

Berchemle1 115,

Anvers (Borgerhout) Belgium

(J. Lamoen, Director)

Laboratorium voor Hydraulica der Univeraiteit,

St. Pletersnieuwstraat 69 ,

Ghent, Belgium

(L. J. Tison, Director)

Laboratoire d'Hydraulique Fluviale de la Faculté des

Sclences appliquées de l'Université de Liègo,

Qua1 de Rome 139.

Liège, Belg1um

(F. Campus, Director)

CZECHOSLOVAKIA Státni ústavy hydrolog1cky a hydrotechnicky T. T. Masaryke,

Podbaba,

Praha, Czechoslorakia

(J. Smetana, D1rector)

FRANCE Laboratolre Central d'Hydraulique,

Charenton prè Par1s, France

(J. Laurent, Director)

Laboratolre Dauphinols d'Hydraulique,

Ateliers Neyret-Beyller et Picard-P1ctet,

Grenoble (Isère) France

(P. Danel, D1rector) 
154

FRANCE (cont'd) Laboratolre de l'Ecole des Ingénleurs hydrauliciens, Grenoble (Isere) France

(P. Danel, Direotor)

L'Inst1tut Electrotechnique et de Mécanique appliquée de l'Unlversité de Toulouse,

Toulouse, France

(L. Escande, Director)

Laboratolre de la Soclété Hydrotechnique de France, Chatoux, France

GREAT BRITAIN The Whitworth Englneer1ng Laboratoriea,

Victorla University,

Manohester, kingland

(A. H. G1b8on, D1rector)

Nat1onal Physical Laboratory, Englneerlng D1v1sion, Teddington, England

(G. A. Hankins and L. E. Proseer, Directors)

Hydraulics Laboratory, Imper1al College,

University of London.

Exhibition Road, South Kensington,

London, England

(C. M. White, Director)

ITALY

Instituto di Idraulica e Construzionl Idrauliche, Plazza Leonardo da Vinol 32 ,

Milan, Italy

(G. de March1, Director)

Inst1tuto d1 Idraul1oa de la Universita d1 P1sa,

Via Diotisalvi.

P18a, Italy

(A. Rastrell1, Direotor)

THE NETHERLANDS Waterloopkundg Laboratorlum,

Raam 61,

Delft, The Netherlands

(J. Th. Th1j8se, Director)

SWEDEN

Vattenbyggnadslaboratorlet vid Kungl. Tekniaka Högskolan,

Valhallavágen,

Stockholm, Sweden

(B. Hellström, Director)

Vattenbyggnadsbyrån,

Humlegårdsgatan 29.

Stockholm, Sweden

(P. G. Hörnell, Director)

SWITZERZAND

Laborato1re d'Hydraulique de I'École d'Ingén1eurs

de l'Unlversité de Lausanne,

Rue de Geneve 67,

Lausanne, Sw1tzerlanđ

(A. Stuoky, Director)

INDIA

Punjab Irrigation Research Inst1tute,

Lahore, India

(H. L. Uppal, Director)

Central Irrigation Hydrodynamie Fesearch statror.

Poona, Indla

(K. K. Framjo, D1rector)

INDONESIA

Waterloopkundig Laboratorium,

Bandoeng, Java

Temporary address: M1jnbouwatrat 5, Delit, Holland

(H. VIugter, Director)

BYRIA

Laboratolre d'Hydraulique de I'Ecole Francalse

d'Ingénleurs'de Beyrouth,

Beyrouth, Syrla

(E. Crausse, Director) 


\section{BUBJECT INDEX OF PROJECTS}

Aerosols, natural, properties .... 97

Air lifts

operating characteristics ......998

performance prediction ..........998

A1r mas maps ................112

Anchors, concrete mooring (158) ... 54

Apparatus

flumes, orltical depth (261) ....990

1rrigation

automatic controls (29) ........ 15

portable slphons $(24) \ldots \ldots \ldots \ldots 13$

laboratory equipment (49) .......20

manometer, high head .............121

Polariscope ....................123

" procedures (119) ....4 40

rain gages $(261) \ldots \ldots \ldots \ldots . . . .90$

sand separator $(52) \ldots \ldots \ldots . . .21$ sediment

analys18 (194) .............66 66

bed load samplers $(i 94) \ldots \ldots .666$

suspended load samplers $\left(i g j^{\prime}\right) \cdots 66$

" (1025) .100 settling, fall velocity $\left(\begin{array}{l}51 \\ (183) \ldots \ldots .62\end{array}\right.$ veloo1ty-head rod (261) ..........990 water ohannel, olroulating (i74). 58 waterstage transmitter (261) ....990

\section{Beokwater}

channels

artif101el roughne 8 .........100

varlous seotlons $(64) \ldots \ldots \ldots \ldots$.......... curves, experimental .............101 tallrace, Bouldar Dam ................

Baffle plers, caritation

Bluestone Dam, W. Va. (199) ..... 68 Claytor Dam, Va. (203) .......... 69 Narrow Dam, Ark. ..............136

Barges

resistance in shallow canals (126) 41

Barriers, debris

Arroyo Seco Canyon, Cal11. $(i 304 j \cdots, 96$

Beaches

equilibrium prop1le (181) .......6 61 erosion control (97) ............ 34 model laws (184) ...............62 protective structures $(38)$....... 17 wave action (182) .............62

Bear1ngs, thrust

Iriction 10sses (801) .........998

Bentonite suspension

flow patterns

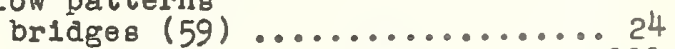

Tacome Narrows bridge ..........111 testing technique (119) .........

Boundary layer removal cylinders (91)

Breakwaters energy absorption (182) .......66 62 rubble-mound $(257) \ldots . . . . . .89$
Breakwaters

wave action

Agate Bay, Minn. .............140

Alameda, Cal11. (259) ......... 89

Anahe1m Bay, Cal1f. (242) .......8 83

Gary, Ill. (148) ............. 50

Hunters Polnt, Calif. (34) ...... 16

Monterey, Cal1f. (249) .........86

Terminal Island, Cal1f. (258) ...89 wave pressures $(256)$........... g8

Bridge plers

flow patterns (59) .............. 24

Los Angeles River (187) ..........6.63

Bridges, alrflow patterns

general studies (59) ............24

Tacoma Narrows, Wash. ............111

Buoys, boat-type

loading and stability

Canals

oheck station gates

All-Amerioan Canal ..............124

linings (15l) ................ 52

navigation

Panama (180) ...............6 61

St. Mary 81 Rer, Mich..........139

overohute design

All-American Canal ............118 surges

Panama Canal (1200) ...........128

พasteway entrances

Friant-Kern Canal .............120

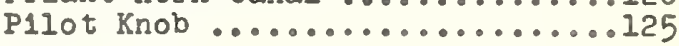

Cavitation

bafile plers

Bluestone Dam, W. Va. (199) ....668

Claytor Dam, Va. (203) .........69 69

Narrows Dam, Ark. ...............136 bas1c research

Bur. Reolamation (172) ........ 58

Cal11. Inst. Tech. (15) ........ 9

Taylor Model Basin (79) ........ 29

gate slots

Bull Shoals Dam, Ark. (200) ....66 68

hydraulic structures

boundary mlealignment (90) ..... 33

intakes, dams

Garrison Dam, N.C. (210) ...... 72

plpe lines

elbow and valve (143) ........ 47

pumps, research

adj. blade, axlal flow (140) .... 46

" ", senage (141) ......4 47

a1r content of water $(822) \ldots . .996$

submerged bodies ................103

turbines, research

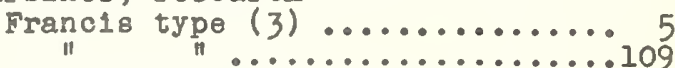

propeller type $(2 j \cdots \cdots \cdots \cdots \cdots \cdots \cdots$

turbines, tests

cr1tical sigma (122) .........4 40

R10 Negro, Uruguay .............109

Sao Paulo, Braz1l ............109 valves

Alamogordo outlet .............12l

Shoshone Dam .................120 
Caritation

water tunnel

vened-turns (130)

Channel Improvement

confluences, bridge plers

Los Angeles River

confluenoes, curves

Los Angeles R1ver (188) ......663

flood control

Brady Creek, Tes. (227) ...... 77

Cumberland, Ma. (230) ........ 79

Johnstown, Pa. (233) .........8 80

Los Angeler R1ver (1332) .......130

Memphis harbor, Tenn. (234) ....80

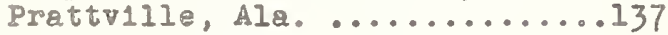

Santa Ane R1ver, Cal11........130 meandering

M1se1sipp1 R1ver (228)........ 78 nav1gation

Ábsecon Inlet, N.J. (1143) ....139

Calcas1eu River, La. (243) .....8 83

Columbla R1ver, Ore. (1106) ...131

Deleware River, Pa. (244) ..... 84

" $(245) \ldots 84$

Hell's Gate Canyon, N.Y.........11

Lynnhaven Bay, Va. (246) ....... 84

M1dale M1 (248) …… 85

Mldway Islends $(247)$.

M1881sв1pp1 R1ver, La. (232) ... 79

St. Johns R1ver, Fla. (253) .... 87

St. Lairence R1ver, N. $Y_{0}(231) .79$

St. Marys R1ver, M1ch. .........139

Savannah RIVer, Ga. (25I) ..... 86

Southwest Pass, La. (252) .....8 87

Umpqua R1ver, Ore. (255) ...... 88

Channel, c1rculat1ng water (174) ... 58

Channels, conservation

11n1ngs, capro1ty $(152) \ldots \ldots \ldots 52$

Compresslble pluids (1045) ........997

Conerete abrasion

Bonnev11le Sp11lway Dam, Ore....130

Condenser coollng water

reclrculation, river............119

Culverts

capsc1ty

corrugated p1pe (115) ........ 38

concrete $(108) \ldots \ldots . . . \ldots 37$

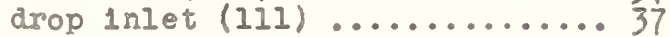

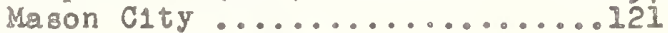

inlets

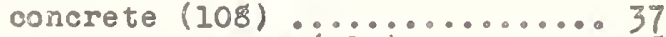

corrugated p1pe (115) ................ 38

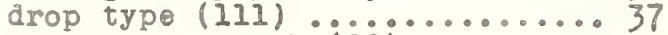

general research (99) ....... 35

outlets

energy d18s1pator (115) ...... 38

general research (99) ........... 35

SAF st1111ng basin .............104

Currents

channels

M1dwey Islands $(247) \ldots . . . .85$

barborg

Apra Harbor, Guam (12) ....... 8
Cut-offs

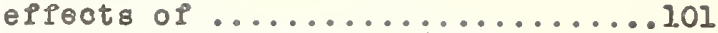

St. Johns River, Fla. (253) ......8 87

Dams, subwerged

flow oharacterist1cs ............125

Density currents

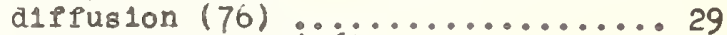

Intarnal waves $(76) \ldots \ldots . . . \ldots 29$

model lews $(159) \ldots \ldots . . . . . . .55$

reservo1r's

suspended sediment $(8) \ldots . . . . .7$

salt water intrusion

Celcasieu R1ver, La. (243) .....8 83

Intracoastal Watorway (250) .....8 86

Lower M1881881pp1 R1ver $\{1335\} .140$

Panama Canal (1201) ............. 128

Sacramento San Joaqu1n, Cal11. ..126

Southwest Pass. La. (252) ...... 87

turbulence $(8) \ldots . . . . . . . . . . .77$ , artiliciai $(76) \ldots 29$

\section{Dralnage}

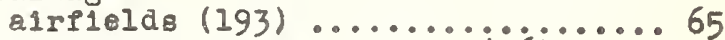
Coachella Valley, Callf. (26) ..... 14 so11 permeeb111ty (28) .......... 15 Dredge, suct1on heads (220) ........75 Dry dooks, f1111ng systems (157) ... 54 Erosion control

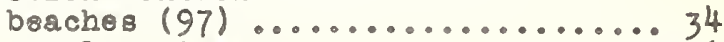

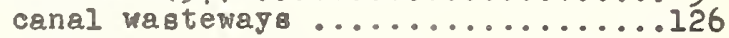
dams

Bonnev1lle Sp1llway Dam, Ore....130

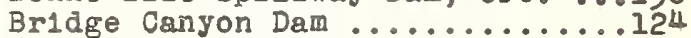

Republ1can R1ver, Neb. (2i2) ... 72 вp111พลy

Ch1ppewa Reservo1r (107) ....... 36

Du Bay Dam, W18.................113 streams

meandering control (226) .......77

mountain channels $(1304) \ldots \ldots 16$ structures

debr1s barr1ers (1304) ..........116

${ }^{n}$ design (9) ${ }^{n}$ Arroyo seco ....................... 96

revetments (ii) ......................

Erosion, research

effect of vegetation $(263) \ldots . . .992$

"

mounta1n watersheds $(261) \ldots . . . . .990$

prediction of rate (10) .............. 8

stream bed $(69) \ldots . . . . . . . . .27$

Evaporation

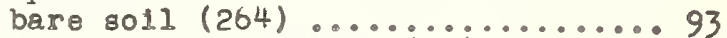

ollect of turbulence (77) ........ 29

evapo-transp1ration (150) ............50

land and rloet1ng pane $(225) \ldots . . .104$

land pans (224) .......................... 104

reservolrs, W1 scons1n valley ......114

small drops ..................... 97

watersheds

lake watershed, M18s. (224) .... 76

Shaver Creek, Pa. (131) ....... 43

F1re 11ghting equipment

f1re mon1tors $(71) \ldots \ldots \ldots \ldots . \ldots . \ldots . . \ldots 103$ 
Fire e1ght1ng equipment

rog nozzle日 $(48) \ldots . . . . . . . .20$

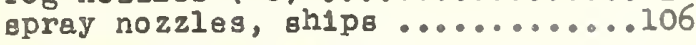

F1sh traps, Kesw1ck Dam ..........122 F1shways, MoNary Dam, Ore. (189) ... 64

Flood control

effect of forest vegetation (264) 93 llow 11 nes

M1881881pp1 River (415) .............. mountain channels $(1304) \ldots . . . .116$ rivers

Brady Creek, Tex. (227) ...... 77

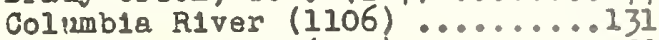
Cumberland, Ma. (230) ..........79

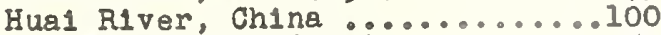
Johnstown, Pa. (233) ...........80 Los Angeles River (1332) ........130 Lower M1881981pp1 R1ver $(237) \ldots 81$ Memph1s, Tenn. (234) ........ 80 M111 Creek, Oh10 (1226) ............... M1881881pp1 Basin (236) ........ 81 M1вв18в1pp1 R1ver (229) ........ 78

$(238) \ldots \ldots . . .81$

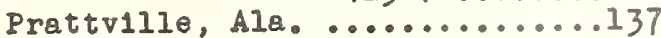

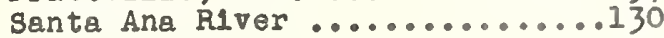

mood forecasting

B18 Eau Pleine R1ver, W16.......114 teohn1ques $(167) \ldots \ldots . . . . . . .56$

Floods

Irequenc1es, Wisoonsin (1300) ....112 hyarograph, Ralston Creek, Ia. (85) 31

Flow nozzles

d1 soharge coefr101ents $(526)$....107

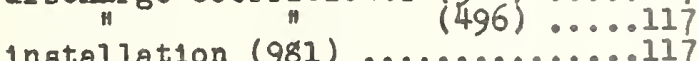
pressure d1stribution $(72 j \ldots . . .28$

\section{Flumes}

meter1ng

control section (267) ...........994

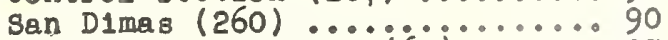

short, bas1c research $(62) \ldots . . .25$

Fog, particle $81 z \theta \ldots . . . . . . . .997$

Fraotionet1ng columns

flow character1st1cs (1020) .....110

Gas, oompressible flow (95) ....... 34

Cates

automat 1c

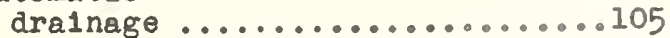

Grand Coulee Pumplng Plant ....125

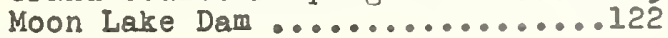

ooster

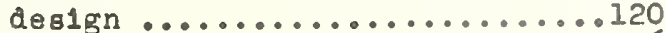

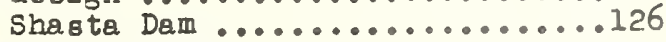

design of seal

Grand Coulee Dam ..............119

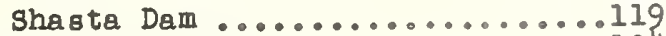

llap, Glla Pumping Plant No. $1 \ldots 124$ miter,forces (1311) .............128 radial

Grand Coulee Pumping Plant .....125

hlgh head, Dav1 g Dam ............124 ring follower, llange gaskets....119 slots, cavitation $(200) \ldots . . . . .668$
Gater

slulce, disoharge ..............114 submergible tainter

st. Anthony Falls, Minn. (860) ..131

Ground water

Coachella Valley, Cal1I. (26) .... 14

Coshocton, Oh10 (150) ........... 50

lake ratershed, M18в. (224) ...... 76

Prospeot Valley, Col............. 99

Ralston Creek, Iowa $(66) \ldots . . . . .26$

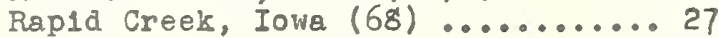
" spec1e10 yleld, theory $(170) \ldots 57$ Susquehanna R1ver (137) ................. 45 unseturated flow $(169) \ldots . . . . . .57$

Gulde vanes

bas1c researoh (104) .............36

turns, water tunnels $(130) \ldots . . . .43$

Harbor improvement

Agrate Bay, M1nn. .............................. Alameda, Cal1 $(259) \ldots \ldots . . . . . . .89$ Anahelm Bay, Cal1f. (242) ........ 83 Apre, Guam (12) ................. 8

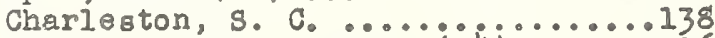
Hunter's Point, Cal1i. (34) ....... 16 Meuph18, Tenn. (234) ............ 80 Monterey, Cal11. $(249) \ldots . . . . . . . .86$ Sapannah R1ver, Ga. (25i) ......... 86 W11m1ngton, Del. (1.231) ............140

Heat tranafer

p1pes (93) ……............... 33

Hydraulic jump

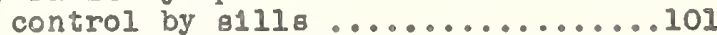

length orlterion $(88) \ldots . . . . . . . .32$

Hyarologic experiment atation (150) . 50

Hydrology

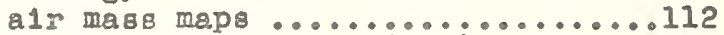

evapo-transp1ration $(150) \ldots . . . .55$

forecasting

runoff and floods (167) .........56

runoff, seasonal (168) ........... 56

inflitration

denudetion effects (27) ........ 14

"

Influence of vegetation $(265) \ldots 93$

phys1cal, chem1cal faotors $(25)^{\circ}$. I3 range management pract10es (27) ... 14 streams, stage-discharge

Iowa streama $(67) \ldots . . . . . . .26$

Susquehanne R1ver $(i 36 j \ldots . . . . . . .45$

W1scona1n etreams (1300) .........112

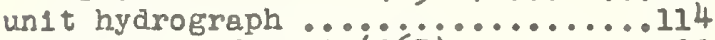
vegetation, forest $(263) \ldots . . . . . . .992$

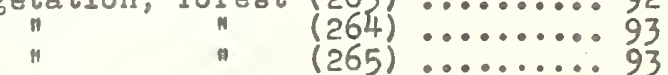

watershed management

Slerra Nevada (262) ........... 92

Southern Cal1forn1a (261) ...... 90 watershed studies

Bayou Duplant1er, La. $(28,224,225) 104$

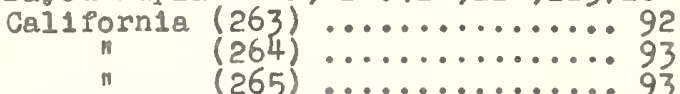

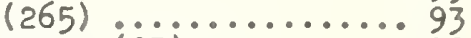

Cal1forn1a areas $(23) \ldots . . . . .12$

c1ty Park Lake, La. (28) .......... 104 
Hyarology

watershed studieg

Ralaton Creek, Iowa (66) ......26

Rap1d Creek, Iowa (68) ........ 27

San D1mes Experimental Forest

$$
\text { (261) ...............90 }
$$
Shaver Creek, Pa. (i3i) ....... 43
Susquehanna River (138) $\ldots \ldots .46$ U.S. Waterway s Exp. Station, M18. (224) .......76

\section{Intakes}

Alva B. Adam B Tunnel ............122 condu1t $t_{B}$ deslgn $(218) \ldots \ldots \ldots \ldots 74$ oulverts, Mason C1ty .............121 for drop splliways (112) ........ 38 Garr1son Dam, N.D. (210) ........72 pump, Paralba River, Brazil (78) . 29 short p1pes (163) ............ 55 street, curb (193) ............ 65

Irrigation

canal and ditch linings (151) ... 52 farm 1pe l1nes (29) ............ 15 farm structures (24) ............ 13

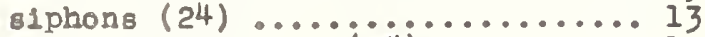
so1l permeab111ty $(28) \ldots \ldots \ldots \ldots$. I5 sprinklers (29) ................ I5 water measurement

fleld meters $(24) \ldots . . . . . . .13$ float meters $(24) \ldots \ldots \ldots \ldots . . .13$

furrow meter (24) .............13

integrating instrument $(54) \ldots .22$ water supplies (23) ............ 12

Jettles

Absecon Inlet, N. J. (1143) .....139 dosign and location (38) ......... 17 Lynnhaven Inlet, $\mathrm{Va} .(248) \ldots . . .85$

jets

Iree, air ....................

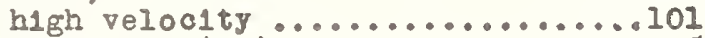

submerged $(75) \ldots \ldots \ldots \ldots \ldots \ldots . .28$

Laborator1es

equ1pment, design (74) ........ 28 hydraulic manual .............. 98

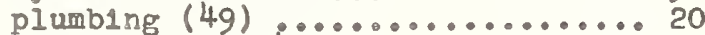
pump testing (45) ............... 19

Lake levels

effect of storm winds (160) ..... 55

Levees

llow by electric analogy (37) ... I seepage, orltical gradients (3i)! I6

Locks

approaches

Bonnev1lie Nav1gat1on (1106) ...131 Demopol1s Dam, Ala. (204) ...... 70 M1s81681pp1 R1ver, Guttenberg, Ia. 131

M1s81so1pp1 R1ver, Trempealeau, W18. (1037) ..........131

Panama Canal (1201) .............128 culvert Intakes and valves (I204). 129 f1lling and empty1ng systema

MoNary Dam, Ore. (191) .......6 64

M1s81s81pp1 R1ver, aux1I1ary locks (197) ........66 66 M1ss1ss1pp1 R1ver, Hastings, M1nn. (861) .........131
Locks

filling and emptying systems M1 s81881pp1 R1Ver, Keolsuk, Ia. (196) ..........667 M1se1se1pp1 R1ver, St. Lou1s, Mo. (198) ..........67

New Jersey sh1p Canal, N.J.(223). 76 Oh10 R1ver, New Cumberland,

$$
\text { Pa. (195) ..........66 } 66
$$

Panama Canal (1203) ...........129 Sault ste. Marle, M10h. .......... I31 forces on ships

New Jersey shtp Canal (223) .....76 Panama Canal (1202) ............128

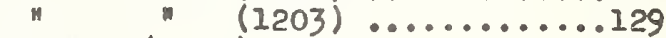
manlfolde $(1013) \ldots \ldots \ldots \ldots \ldots \ldots . . \ldots \ldots$

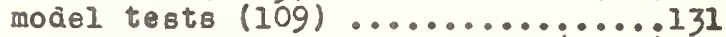
prototype model verification (i035)131 tainter gates

St. Anthony Falls, Minn. (860) ..131

Machinery, hydraul10

test1ng techn1que (830) .........996

Manometer, high-head mercury ........121

Measurement of discharge

by raả10-act1ve mater1als (135)... 44

Metera

gasoline, cal1bration (124) ......4 41

inf1ltrometer (265) .............99

1rrigation

fleld, portable (24) ........... 13

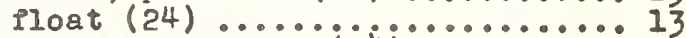

Purrow, portabie $(24) \ldots \ldots \ldots \ldots$........ 13

integrating (54) ................22

oris1ce

1nstallation (98I) ..............117

pulsating flow $(128) \ldots \ldots \ldots \ldots . . .42$

p1pe-tee (144) ................ 48

rain gages $(261) \ldots \ldots \ldots \ldots \ldots . . . . .99$

so11 mo1sture $(20) \ldots . . . \ldots \ldots \ldots . . .11$

$1 "$ (25)

veloo1ty

current, in p1pes ...........999

electro-magnet10 ( $46 j$............ 19

"

hot w1re $(18) \ldots \ldots \ldots \ldots \ldots \ldots . . .10$

veloc1ty head roj $i 26 j i \cdots \cdots . .28$

Ventur1, plezometer holes $(134)$... 44 water, callbration (124) ........4 41

Model laws

berches (184) ...............6 62

deng1ty currents $(i 59) \ldots . . . \ldots . .55$

dynamic o1m1larity

small models (125) .......... 41

hydraul10 structures (36) ........... 17

setti1ng basins (106) ............ 36 otreams

bank erosion (225) ............76

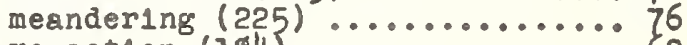

หave action $(184) \ldots \ldots \ldots \ldots \ldots \ldots . . \cdots 6_{2}$

Model veriflcation

prototype confirmation

general (221) ............... 75

looks $(1035) \ldots \ldots \ldots \ldots \ldots \ldots . . . \ldots 131$ 
Model verifloation

prototype conP1rmation

st1lling basing ..............101

stream control (i32) ..........4 43

Nozzles

disoharge coefflclents (496) .....117

(526) ....107

Plre mon1tors (71) .............27

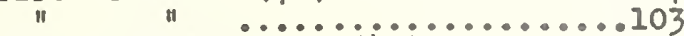

fog, f1re f1ghting $(48) \ldots \ldots \ldots . .20$ hot water $(94) \ldots \ldots \ldots \ldots \ldots . . . \ldots 34$ Installation (981) ................17 pressure distribution (72) .......28

\section{Open channels}

alr entrainment (100) ......... 35

artiflcial roughness

measurement $(30) \ldots \ldots \ldots . . . .15$

rectangular channel ............100

trlangular channel ...........100

backwater

artiflcial roughnes $\ldots \ldots \ldots . . .100$

vary 1ng roughness $(64) \ldots . . . . .26$

control sections (267) ........... 94

ourves

(132) .........4 43

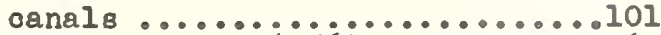

superelevated (i86) ............6 63

large, roughness coefflclent ....127

steep slopes (1019) .............110

supercritioal flow

a1r entrainment $(100) \ldots \ldots \ldots .35$
diverging seotions $(70) \ldots \ldots \ldots .27$

lateral contractions (58) ......23

$\ldots \ldots . . . . .103$

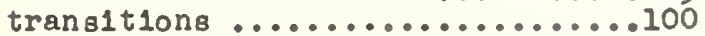

unsteady flow

computation methods (86) ...... 32

friction ( 890$)$................110

veloolty distribution

rectangular (102) ............. 35

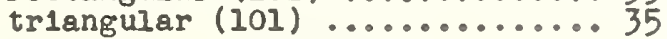

Or1f1ce gate, callbration .........123

Or1f1ce meters

Installation ( 981 ) .............117

pulsating flow (128) ........... 42

Or1P10es

hot water (94) ................. 34

varlous 11quids ...............108

Outlets

culverts (1Il) $\ldots \ldots \ldots \ldots \ldots \ldots \ldots . . . \ldots 17$ corrugated plpe $(i 15) \cdots 38$

drop splílway (113) ............. 38

Lower Caney Lake, La.............. 104 plpe, energy dissipators (1269) ..95

Outlet works, dams

Anderson Ranoh Dam ............118

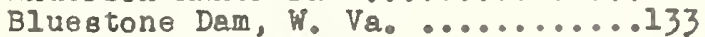

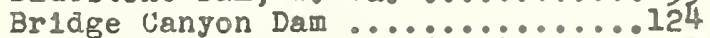

Bull Shoels Dam, Ark. $(200) \ldots . .68$

Canyon Ferry Dam ....................

Conemaugh Dam, P8. (201) ........68

Dale Hollow Dam, Tenn. ............134

Dav1s Dam .....................119

Detro1t Dam, Ore. (205) .........70
Outlet works, dams

Dorena Dam, Ore. (192) ..........66 65

Fall Rlver Dam, Kans. (207) ....... 71

Fort G1bson Dam, Okla. (209) ...... 71

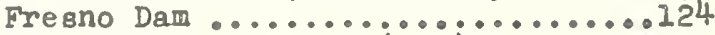

Garr1son Dam, N. D. (2Ii) ........7 72

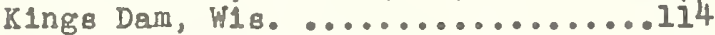

Mud Mountain Dam, Wash. ..........130

San Gabriel R1ver, Cal1f. (1333) ..130

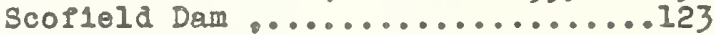

Shadow Mountain Dam ..............123

Wolf Creek Dam, Ky. (1340) ........137

Penstooks

a1r vents, Anderson Ranch Dam ....122

Bluestone Dam, $W . V a . . . . . . . . .132$

Fort Peok Power Plant, Mont......136

Norrork Dem, Ark. ...............136

prototype pressure measurements ...136

P1l1ng, sheet steel (185) ........6 63

P1pe pittings

corrosion (179) ..............61

gate and chook valves $(56) \ldots \ldots . .23$

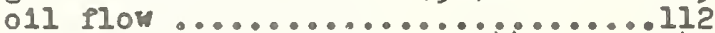

tee as measuring device (i 44 j)..... 48

P1pes

a1r

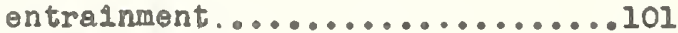

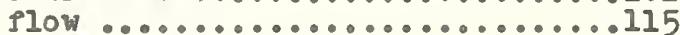

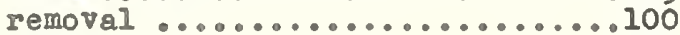

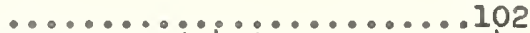

bends, guide vanes $(i 4 j) \ldots \ldots . . .44$

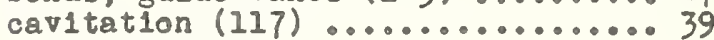

corrosion

aluminum (63) .................25

condenser tubes $(179) \ldots . . . . .661$

p1ttings (179) ...............61

non-ferrous materials (i79) ..... 61

varlous materlals (154) ........ 53

entrance sectlons $(96) \ldots . . . . .34$

plow of mixtures

coal suspenslons (92) .......... 33

gol1d-gas $(40) \ldots \ldots \ldots \ldots \ldots \ldots . . \ldots \ldots$

suspenstons $(98) \ldots \ldots \ldots \ldots \ldots . . . . . .35$

two-phase, two-component $(4 i j \cdots$ ls

Priotion

aluminum (63) ..................25

artiflelal roughness (i) ........ 5

partly full ..................... g9

heat transfer (i) .............. 5

man1fold ports $(65) \ldots \ldots \ldots \ldots \ldots 33$

" " (82) ............ 31

short plpes and intakes (i6j) .... 55

small slphons (116) ............... 39

surge suppressors (127) ........... 42

tees (144) ....................... 48

turbulence $(173) \ldots \ldots \ldots \ldots . . . . . .58$

unsteady Plon $(42) \ldots \ldots \ldots \ldots \ldots . . . . .18$

veloolty pluotuations $(46) \ldots . . . .19$

relded Junctions (32) ............. 16

P1tot tubes

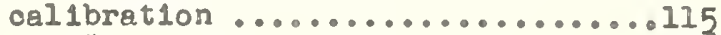

${ }^{4} \quad \ldots \ldots \ldots \ldots \ldots \ldots \ldots \ldots \ldots . . . \cdots 115$

d18oharge of pree jets (84) ....... 31

standard for pump tests (43) ...... Is 
Pl umbing

backflow prevention (49) ........20

corrosion (49) ................ 20

cross-connectlons

general research (49) .........20

11xtures (49) ................2 20

ilxture traps

self-siphonage $(166) \ldots . . . \ldots 56$

grease 1nterceptors ..................

limlts of stack venting $(164) \ldots 55$

wet vents $(165) \ldots \ldots \ldots \ldots \ldots \ldots . . . \ldots 55$

Polarlacope, fluid .............123

procsdures (119) .............. 40

Pollution, sewage

St. Johns River, Fla. (254) .....8 87

Pontons, bridge, dosign (222) .....75

Porous media, llow

bas1c ressarch (60) ............. 24

compressible flulds (i045) ...... 97

dams and levees $(31) \ldots . . \ldots \ldots . . .16$

" "

two-phase Iluids $(39 j) \ldots \ldots \ldots \ldots . . . \ldots$

Pressure theasurement

electric analogy $(72) \ldots \ldots \ldots \ldots 28$

electronic method $(146) \ldots . . . . .49$

Pumps

air l1Pt

operating characterlstics ......98

performance prediction ........998 centrifugal

adjustable blado

performanco, cavitation (140). 46

adjustable blade, sewage

performance, cavitation (141). 47

cavitation (822) ................96

effects of viscosity ..............103

Plow obaracter1st1cs (13) …. 9

plow patterns at intakes (i62) . 55

Grand Coulee (14) ..............

mult1-stage $(89) \ldots . . . . . . . .32$

performance compliation ( 829 ) .. 96

starting and stopping ..........26

tests

performance, full acale .......110

standard P1tot $(43) \ldots . . . . .18$

velocity and pressure in volute

(827).. 96

jet. Kesw1ck Dar 11sh trap .......122

Pump test1ng laboratory (45) ...... 19

Reservolra

evaporation

W8cora1r River valley .........114

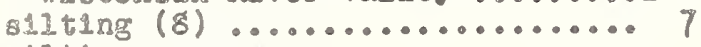

s11ting surveyg

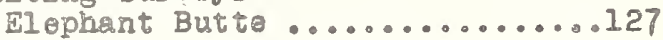

Revetments

beach protection (97) .......... 34

stream control (11) ............. 8

meandering control $(226) \ldots . . .77$

Roo 18

presoure distribution (83) ...... 31
Roughress

artifiolal

meagurement (30) ............. 15

pipes (1) ................... 5

rectangular channela ...........100

triengular channels ...........100

coefflofents, large channels .....127

elfoct on baokwater (64) .......26

evaluation ......................101

Runof

denudation effecte (27) ......... 14

effect of forest vegetation $(263) .92$

$\begin{array}{llll}\text { " " } & \text { " } & (264): 93 \\ \text { " } & (265): 9\end{array}$

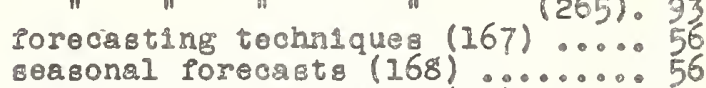
snow survey 3, Colorado $(55) \ldots . . .22$ theoretical ansiys1s ............113 watorshods

Bayou Duplant1er, La, (28) (22k)

(225) ...2048

B1g Eau Pleine River,

Cochooton, Ohio (150) ......... 50

Iowa streans $(67) \ldots \ldots \ldots . . . . .26$

lake watershed, Mss. (224) ... 76

Ralston Creek, Iowa (66) .......26

Rap1d Creek, Iowa (68) .........27

Shaver Greet, Pa. (131) ....... 43

Susquohanna River (138) ........ 46

Selt water intrusion,

Calcasleu R1ver, La. (243) .....8 83

Lower M1s81s81pp1 R1vor,L\&.(1335). 140

Panama Canal (1201) .............128

Sacramento San Joaquin, Cai1s....126

Southwest Pass, La, (252) .......87

sand olassiploation

BottIIng veloolty

apparatus $(52) \ldots \ldots \ldots \ldots \ldots . . \ldots . . .621$

vethods $(52) \ldots \ldots . . . . . . . . .21$

Sand traps, design $(53) \ldots . . . . .22$

Sediment

anelysis methods (194) ........66 66

bed loed

epfect on rating IIune (260) ...990

dobris barrtere

Arroyo seco (1304) .............16

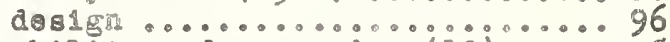

stab1l1ty under erogion $(10) \ldots . .8$

sediment characteristica

relation to bed eroslon (69) ..... 27

Sediment atiersion

pump intakes (78)

sediment transportation

bod loge

eppect of pluid properties (103) 36

internal mechanica $(6) \ldots \ldots \ldots .6$

Southwest 8888, La, $(252\} \ldots . . .87$ creep and saltathon............... dens1ty ourrents $(8) \ldots . . . . . .$. ? deposits in retarding basin ........ detent1on resarvolrs (171)..... 57 
sediment transportation

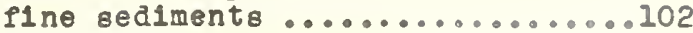

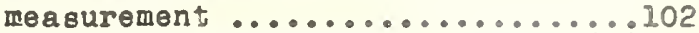
reservolrs, suspended sediment $(8) 7$ sampling (194) ................66 66 suspended load

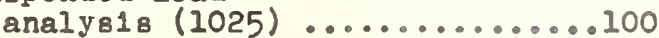

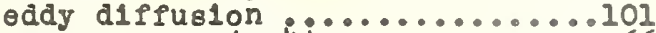
measurement $(194) \ldots . . . . . . .666$

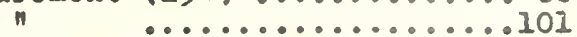

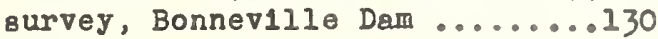

Sett11ng

sand, rall veloolty $(51) \ldots \ldots . . .621$ spheres, boundary influenoe......101

Settling basin

efflc1ency (106) ..............36

Settling tank

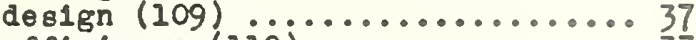

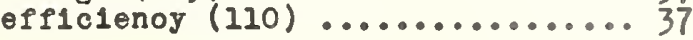

Sh1p $10 g$

cal1bration

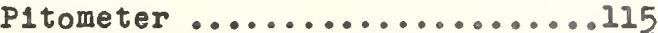

P1tot and impeiler types.........

P1tot type .................116

Bh1pe

condenser scoop

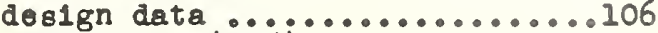

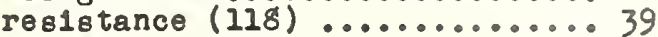

deck edge elevator

heellng effects...............106

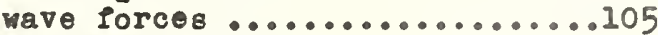

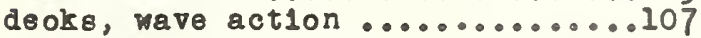

forces, in locks

New Jersey Ship Canal (223) ... 76

Panama Canal (1202) .....................

\section{launohting}

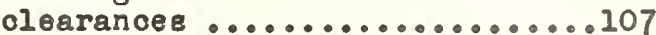

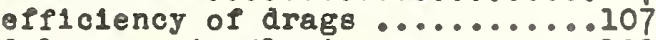

model tests in flowing water.....102

" " " " ....103

movement in oanals (223) ............. 76

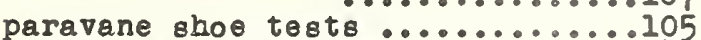

rolling and pitching (121) ....... 40

roll1ng period (5) ............... 6

rudders $(120) \ldots . . . . . . . . . .440$

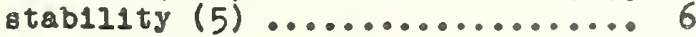

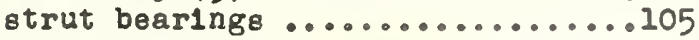

8hore proteotion, etruoturee (38) . 17

silting survoy日

reservo1rs, Elephant Butte ...... 127

Siphons

Irrigation, portable (24) ....... 13 mali p1per (116) ................ 39

slu1 oe gates

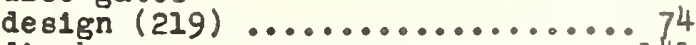

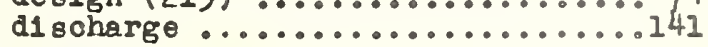

slul ceway 8 , sand

design (53)

Snow surveys

Colorado $(55) \ldots \ldots . . . . . . .22$

photographic $(57) \ldots . . . . . . .23$
So11 mo18ture

Coachelle Valley, Cal1f. (26) ..... 14

Coshocton, Oh10 (150) ............ 50

effect of denudation (23) ......... I?

efpect of freezing $(264) \ldots . . . . .93$

measurement $(20) \ldots . . . \ldots . . . . .11$

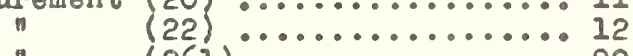

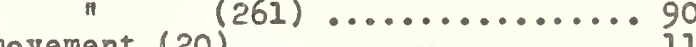

movement $(20) \ldots \ldots \ldots \ldots \ldots . . . \ldots \ldots 11$

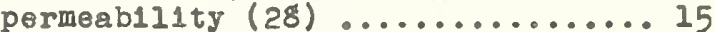

relation to plants $(19) \ldots . . . . . .11$

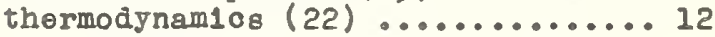

So11 permeab111ty

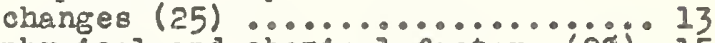
physical and chemioal faotors (28). 15

Sp111ways

compar1son of prof11es (266) .....994 damb

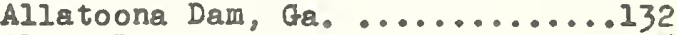

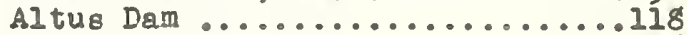

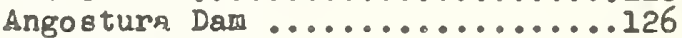

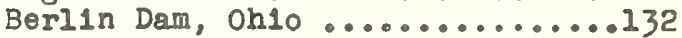

B1g Sandy No. $2 \ldots . . . . . . . . .118$

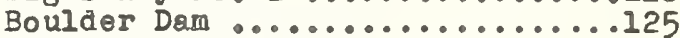

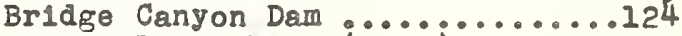

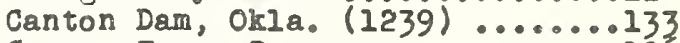

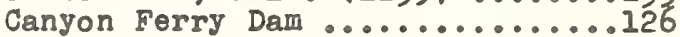

Center H111 Dam, Tenn. (1337) ...133

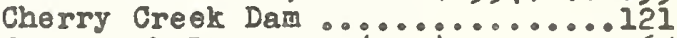

Conemaugh Dam, $\mathrm{Pa},(2 \mathrm{O} i) \ldots . . . .68$

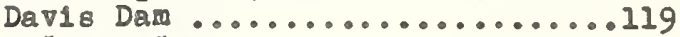

" $\ldots \ldots \ldots \ldots \ldots \ldots \ldots \ldots \ldots . . \ldots \ldots 123$

Detro1t Dam, Ore. $(205) \ldots . . . .70$

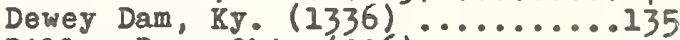

D111on Dam, Oh10 (206) .................

Dorena Dam, Ore. (192) ............. 65

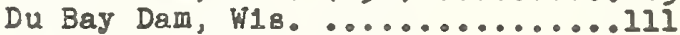

Du Bay Dam apron design ...........113

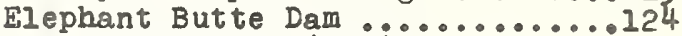

En1d Dam, M188. (208) .......... 71

Experiment Station Dam, M188.

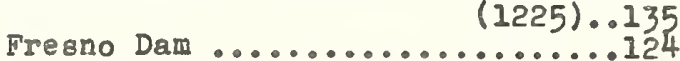

Granby Dam ....................

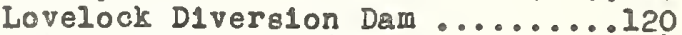

McNary Dam, Ore. (190) .............. 64

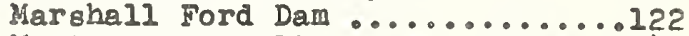

Montmorenoy Fall s Dams, Canada..141

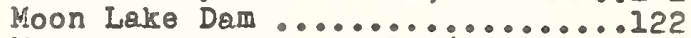

Morganza Floodway, La. (213) ... 73

Orcoola Dam, Mo. (214) ......... 73

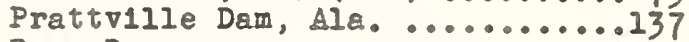

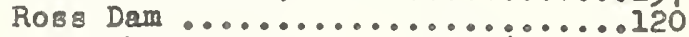

San Gabriel River, Caili. (i33j).130

San Jacinto R1ver Dam ............ 104

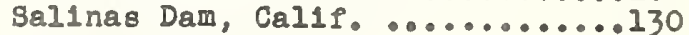

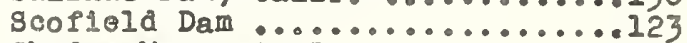

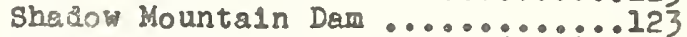

Stevarts Ferry Dam, Tenn. (215)..73

Wh1tney Dam, Tex. $(217) \ldots . . . .74$

Holf Creek Dam, Ky. (1340) .......137

drop, design (112) .................... 37

n, outlet derlgn $(113) \ldots . . . . . .38$ erosion control

Chippewa Reservolr (107) .............. 36

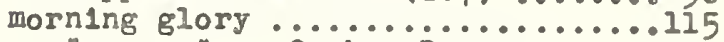
skew (269) ............................ 123 


\section{Sp1llway tunnels}

alr injection .125

Bprinkl1ng systems, 1rrigation

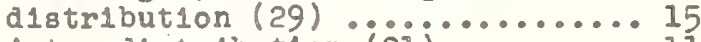
jets, distr1bution $(21) \ldots . . . . .11$

st1ll1ng basing

culverts, SAF type ..............104 dams

Allatoona Dam, Ga............132

Berl1n Dam, Oh10 .............132

B1g Sandy No. 2 .................18

Bluestone Dam, W. Va. (199) ....68 68

Cherry Creek Dam ..............121

Clark H1ll Dam, Ga. (202) ......6 69

Conemaugh Dam, Pa. (201) ......68

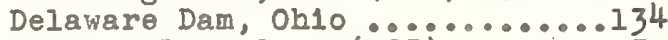

Detro1t Dam, Ore. (205) ........70

Dewey Dam, Ky. (1336) ............. 135

Dorena Dam, Ore. (192) ........ 65

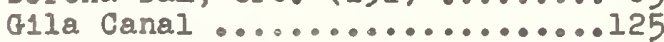

Lower Caney Lake, La............104

MeNary Dam, Ore. (190) ........664 Morganza Floodway, La. (213) ...73 Narrow 8 Dam, Ark. ..............136 Osceola Dam, Mo. (214) ........73 Stewarts Ferry Dam, Tenn. (2ij). 73 Wh1 trey Dam, Tex. (217) ....... 74

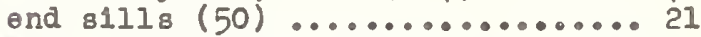
model prototype compar1son ........101 roller-type aotion ................101

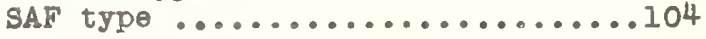

Stream flow forecasts

Colorado (55) ................ 22

n $(57) \ldots \ldots \ldots \ldots \ldots \ldots . . \ldots 23$

stream gaging

art1f1c1al control (132) ....... 43

by alkalin1ty measurements $\ldots . . . .113$ or1t1cal depth plumes (261) ......99 electron10 apparatue (146) ...... 49

Streams

discharge

Iowa streams (67) ............26

W1sconsin streams $(1300) \ldots . . .112$ flood frequene1es, W1sconsin .....112 flow duretion curves (33) ........ 16 flow reoora

Susquebanna River (136) ...... 45 llow record nomograph $(261) \ldots . .990$ forecast1ng techn1ques (167) .... 56 meandering

bas10 research (225) .........76 M1881881pp1 R1ver (228) ........78

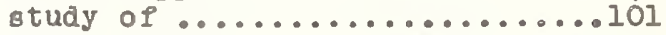
qual1ty of water, R10 Grande ......127 un1t hyarograph ...............11 valley storage

M1881881pp1 R1ver (240) …... 82 water supply forecasting (168) ... 56

Submerged bodie日

Bentonlte method

techn1que (119) ............4 40

(170) .............6 60

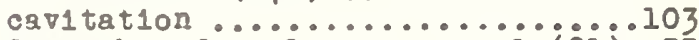
drag, boundary layer removal (9i). 33 pressure distribution

bas1c research (16)
Submerged bod1eg

pressure distribution

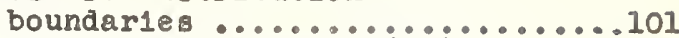

by eleotrio analogy $(72) \ldots \ldots \ldots 28$

theoret10al analy $818(81) \ldots \ldots .30$

vibrations, eylindors (178) ....... 60

Ta1lrace

McNary Dam, Ore. (189) .......... 64

Tanks, oylindrical

wind pressures (1297) ..........111

Tidal flon

canals

Paname (180)

ohannels

Lynnhaven Bay, Va. (246) ....... 84

St. Johns R1ver, Fla. (253) ..... g7

Savannah, Ga. (251) ............86

Southwest Pass, M18018s1pp1

R1ver, La. (252) .....8 87

Umpqua R1ver, Ore. (255) .......88

Towing tank research (139) ........ 46

Trestles

elfeot on river stages (239) .....8 82

Tunnels

Colorado-B1g Thompson ...........122

Mud Mounta1n Dam, Wash. .........130

st. Marys Dam, Canada (216) ...... 73

Turbines

Frano1s type

caritation

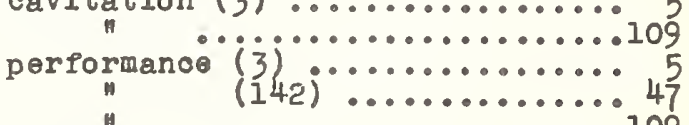

propeller type

cavitation (2)

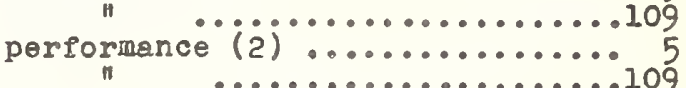

tests

cav1tat1on (122) ,...........4 40

"

performance $(i 23) \ldots \ldots \ldots \ldots \ldots . . .40$ (142) $\quad \ldots \ldots \ldots \ldots \ldots . . .47$

water measurement $(i 3 j j \ldots . . . . .144$

n

Turbulenoe

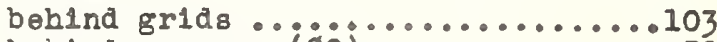

behlnd soreens $(80) \ldots \ldots \ldots \ldots . . . . . . .30$

density currents $_{n}\left(\frac{8}{76}\right) \ldots \ldots \ldots \ldots \ldots . . \ldots 29$

epfect on evaporation $(77 j \ldots . . .29$

measurenent

apparatus (73) .............. 28

techn1ques $(80) \ldots \ldots \ldots \ldots . . . . . .30$

pipes

artif1c1ally rough (1) ......... 5

bas1c research (46) ............... 19

correlation w1th eriotion (173) . 58

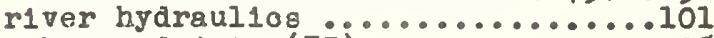

submerged gets $(75) \ldots \ldots . . . .28$

Unsteady llow

computation methods, channels (86). 32 
Unsteady Ilok

Irlct1on, channels (890) ........110

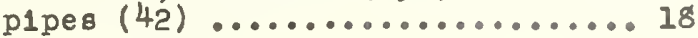

UpI1ft, presaures

or1t1oal gradients (31) ......... 16 llow nets, eleotric analogy .....997

Valves

butterply,Estes Park Power Plant .126 cavitation

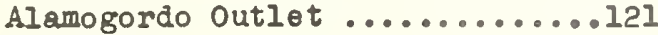

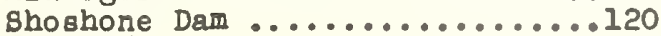

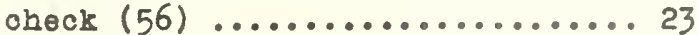

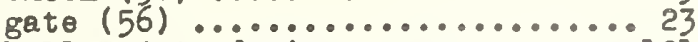

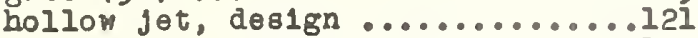
Howell-Bunger, Rosв Dam .........122 needle

Alamogordo Outlet ..............121

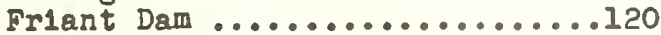

Shoshone Dam ..................119 seotor and talnter

lock culverts (1204) ...........129 sphere, der1gn of seal ...........119

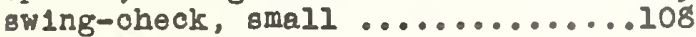
tube, Frlant Dam ...............120

Velocity distribution

around ships ...................101 Jets

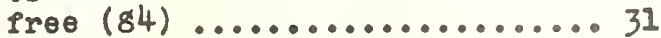

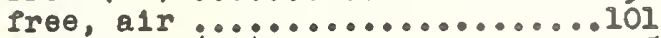

submerged $(75) \ldots \ldots \ldots \ldots \ldots . . . . . . .28$

rectangular channel (102) ........ 35

trlangular channel (101) ........ 35

Veloc1ty measurement

current meter, p1per............ 99

ele otro-magnet1c $(46) \ldots . . . . . . .19$

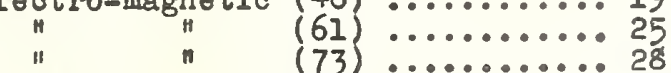

hot wire meter $(18)^{3} \ldots \ldots \ldots \ldots . . . \cdots \cdots$

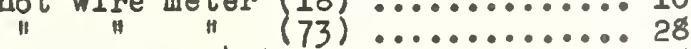

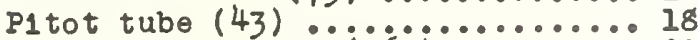
veloc1ty head rod $(261) \ldots . . . . . .99$

Vortexes, over outlets ( 87$) \ldots . . . .32$

Wastevajo

canals

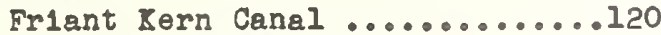

G11a Gravity Ma1n Canal ..........125

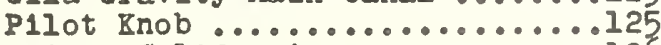

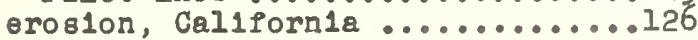

Water channel, c1rculating (174) .. 58

Weter hammer

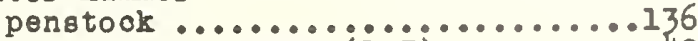

surge suppressors $(127) \ldots . . . . .42$

Water, metastable (94) ........... 34

Water softening

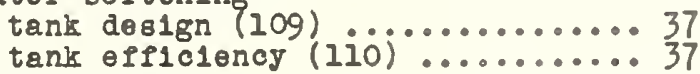

Water tunnel

de日1gn

David Taylor Model Basin (105) . 36

Iowa Inst. Hyd. Res..........103

Penn. State College (129) ..... 42

Un1v. of Cal1f. (44) ......... 19

vaned-turns $(130) \ldots . . . . . . . .43$

variable pressure

des1gn (175)
Wave aotion

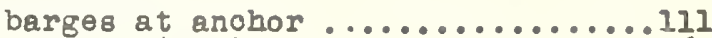

besches $(181) \ldots \ldots \ldots \ldots \ldots . . . . .61$

breakwaterg

Agate Bay Harbor, M1nn. ........140

Alemeda, Cal11. (259) .......... 89

Anahe1m Bay, Cal11. (242) ...... 83

bas1c research (182) .......... 62

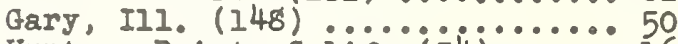

Hunters Polnt, Caili. $(34 j \cdots \cdots . . . .16$

Monterey Harbor, Calif. $(249) \ldots 86$

rubble-mound, 8tab111ty (257) ... 89

Term1nal Island, Cal1f. (258) ... 89

gun mounts on oblps (176) ....... 59

harbors

Agate Bay Harbor, MInn. ........140

Alameda, Cal11. (259) ............... 89

Anahe1m Bay, Cal11. (242) ....... 83 Apra Harbor, Guam (12) ......... 8

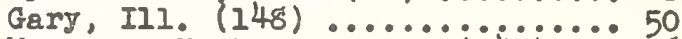
Monterey Harbor, Calil. $(24 \dot{q}) \ldots 86$

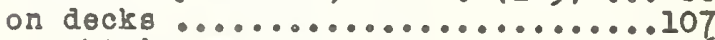
on sh1p's sw1mining pool ...........106

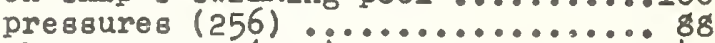
sh1p mot1ons $(121) \ldots . . . . . . . . . . . .40$ shlps, deck edge elevator ............. 105 shore protect1on works $(38) \ldots \ldots . . .106$

\section{Waver}

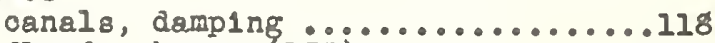

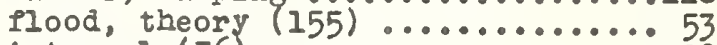

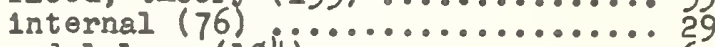
model lavs $(184) \ldots . . . \ldots . . . . . . . .62$ open-channel, contraotions $(58) \ldots 23$ solitary, ext1nction (161) ....... 55 вurpace

generation, forecast1ng (47) .... 19 goneration, w1nd $(4) \ldots \ldots . . . . .19$ osc11latory, theory $(47) \ldots . . . .19$ shallow water $(35) \ldots . . . . . . . . . . .17$

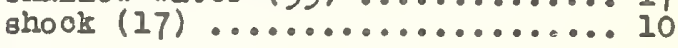

ke1rs

broad-orested, o1rcular (145) .... 48

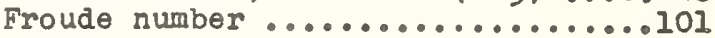
nappe, vacuum effeot ................101 proport1onal, submergence $(i j 3 j \cdots 44$ rock 1111, discharge (270) ....... 95 sharp-crested

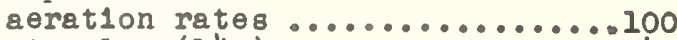

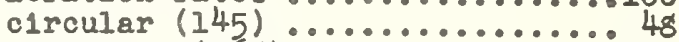

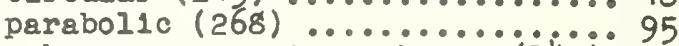
submergence, various shapes (i49). 50

trlangular, varlous 11 qu1di....... 98 sutro, submergenoe ................ 98

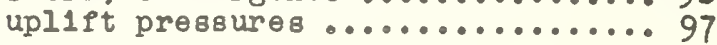
WInd

effect on lake levels (160) ..... 55 pressures

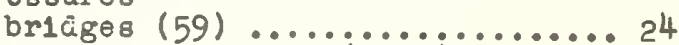
oyl1ndr1cal tanks $(1297) \ldots . . . .111$

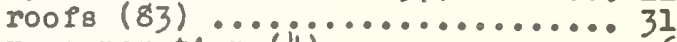
wave generation $(4) \ldots \ldots \ldots \ldots \ldots \ldots \ldots \ldots \ldots \ldots$

" $"(47) \ldots \ldots \ldots \ldots 19$ 


.

